\title{
Site U1410
}

R.D. Norris, P.A. Wilson, P. Blum, A. Fehr, C. Agnini, A. Bornemann, S. Boulila, P.R. Bown, C. Cournede, O. Friedrich, A.K. Ghosh, C.J. Hollis, P.M. Hull, K. Jo, C.K. Junium, M. Kaneko, D. Liebrand, P.C. Lippert, Z. Liu, H. Matsui, K. Moriya, H. Nishi, B.N. Opdyke, D. Penman, B. Romans, H.D. Scher, P. Sexton, H. Takagi, S.K. Turner, J.H. Whiteside, T. Yamaguchi, and Y. Yamamoto ${ }^{2}$

\section{Chapter contents}

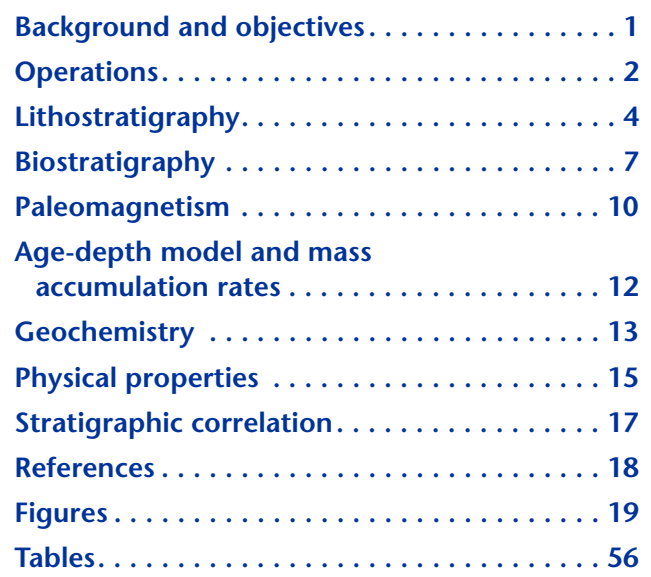

${ }^{1}$ Norris, R.D., Wilson, P.A., Blum, P., Fehr, A., Agnini, C., Bornemann, A., Boulila, S., Bown, P.R., Cournede, C., Friedrich, O., Ghosh, A.K., Hollis, C.J., Hull, P.M., Jo, K., Junium, C.K., Kaneko, M., Liebrand, D., Lippert, P.C., Liu, Z., Matsui, H., Moriya, K., Nishi, H., Opdyke, B.N., Penman, D., Romans, B., Scher, H.D., Sexton, P., Takagi, H., Turner, S.K., Whiteside, J.H., Yamaguchi, T., and Yamamoto, Y., 2014. Site U1410. In Norris, R.D., Wilson, P.A., Blum, P., and the Expedition 342 Scientists, Proc. IODP, 342: College Station, TX (Integrated Ocean Drilling Program). doi:10.2204/iodp.proc.342.111.2014

'Expedition 342 Scientists' addresses.

\section{Background and objectives}

Integrated Ocean Drilling Program (IODP) Site U1410 (proposed Site SENR-23A; $41^{\circ} 19.6993^{\prime} \mathrm{N}, 4^{\circ} 10.1847^{\prime} \mathrm{W} ; \sim 3400 \mathrm{~m}$ water depth) is a mid-depth site ( 2950 meters below sea level [mbsl] paleodepth at $50 \mathrm{Ma}$ ) (Tucholke and Vogt, 1979) in the upper mid-depth end of the Expedition 342 Paleogene Newfoundland sediment drifts depth transect (Fig. F1). The site was positioned to capture a record of sedimentation $\sim 1.5 \mathrm{~km}$ shallower than the largely sub-carbonate compensation depth (CCD) record drilled at Site U1403 (Figs. F2, F3). The location, well above the average late Paleogene CCD, should be sensitive to both increases and decreases in carbonate burial, whether these reflect variations in dissolution related to changes in the CCD, changes in carbonate production, or variations in background noncarbonate sedimentation. Our primary scientific objectives for drilling Site U1410 were

- To obtain an expanded record of lower to middle Eocene drift sedimentation that can be compared directly to the relatively condensed record at Site U1409 drilled on the edge of the drift;

- To capture fine-scale variations in carbonate preservation and lysocline shifts in carbonate-rich sediment that is $\sim 400$ $m$ deeper than at Site U1408; and

- To evaluate the history of deep water and the CCD on sediment chemistry, grain size, and provenance.

Secondary objectives included the possible recovery of specific Paleogene hyperthermals such as the Middle Eocene Climatic Optimum (MECO) for comparison with the record of these events elsewhere, particularly Sites U1404, U1406, and U1408 along the Expedition 342 depth transect.

Site U1410 is a companion site to Site U1409, where we employed an offset drilling strategy to obtain advanced piston corer (APC) records through a thicker section of the same sediment drift. Drilling a similar pair of sites (U1407 and U1408) showed that the more expanded Site U1408 record is essentially a record similar to that at Site U1407 but with much more clay and a somewhat younger uppermost sediment record. We found largely the same geometry in the J-Anomaly Ridge sites, where the center of the drift has a massively expanded record of the same geological intervals that is present in relatively condensed sections at the ends of the drift. Hence, we expected that coring at Site U1410 would 
recover a sequence with more clay but otherwise similar gross stratigraphy to the more condensed companion Site U1409.

The primarily calcareous sequence expected at Site U1410 should record changes in ocean alkalinity and carbonate production. Sites U1403 and U1404 were mainly positioned to capture large-amplitude CCD deepening events such as the carbonate budget "overshoots" that are thought to be associated with the most extreme climate perturbations of the Cenozoic, such as those involved with the Paleocene/Eocene Thermal Maximum (PETM), the late middle Eocene, and the Eocene-Oligocene transition (EOT) (see the "Site U1403" and "Site U1404" chapters [Norris et al., 2014b, 2014c]). Transient shoaling of the CCD in generally carbonate rich sequences should be recorded at Site U1410 by decreases in carbonate preservation and decreasing carbonate content relative to clay or biosiliceous sediment, as we have already observed at Sites U1404-U1408. As an upper mid-depth site on the Newfoundland depth transect at $\sim 3400 \mathrm{mbsl}$, Site U1410 was positioned to allow us to reconstruct small changes in carbonate content between the records of Sites U1406 (3850 mbsl) and U1408 (3022 mbsl) and should have a few intervals in which the sediment is $80 \%-90 \%$ carbonate but also intervals in which carbonate abundance falls in the record. Carbonate content was expected to be generally higher at sites in shallower water depth, such as the majority of the sites located on Southeast Newfoundland Ridge, but less than our shallowest depth Sites U1407 and U1408.

The relatively high carbonate contents anticipated in sediment at Site U1410 should permit the construction of detailed stable isotope records and calcareous microfossil biostratigraphy that can be tied by physical property records and magnetochronology to Sites U1403-U1406 further downslope and Sites U1407 and U1408 upslope. Ties between sites on Southeast Newfoundland Ridge and those on J-Anomaly Ridge will allow the isotope stratigraphy and biochronology developed for Sites U1406-U1408 to be exported to the lower ends of the depth transect.

Ultimately, the goal is to use the combination of the lower and middle Eocene record at Sites U1407U1410 and the younger Paleogene record at Site U1406 to produce composite stable isotope and carbonate content records that can be tied to the more intermittent geochemical records at Sites U1403U1405. Our aim is to match carbonate-rich intervals across all of the J-Anomaly sites with the sites on Southeast Newfoundland Ridge to create an orbitalresolution record of fluctuations in ocean chemistry and deep water origins.
Site U1410 was proposed during Expedition 342 to test the hypothesis that there are several acoustically transparent drift packages on the Southeast Newfoundland Ridge that correlate to similar but more persistently developed reflector units on the toe of JAnomaly Ridge (cored at Site U1403). Drilling on JAnomaly Ridge showed that the uppermost acoustically transparent unit is of middle Eocene to early Miocene age and is separated from a thin, lower, acoustically transparent interval by a set of very well developed reflectors of early Eocene to Cretaceous age. In turn, drilling at Sites U1407-U1409 showed that drift sedimentation begins in the middle early Eocene. We hope to use Site U1410 to determine the onset of drift sedimentation in a record that is likely to have a higher fidelity than the relatively condensed records on the fringes of the sediment drifts.

We hypothesized that Site U1410 would provide an expanded record of primarily calcareous ooze and chalk of rough age-equivalence to sites in deeper water on J-Anomaly Ridge. In particular, Site U1410 should provide a high-deposition rate record of the middle and early Eocene as a counterpart to the largely sub-CCD record at Site U1403 and the shallower records at Sites U1407 and U1408. The combination of these records will improve age and water depth control on the behavior of the CCD in the North Atlantic during this key interval.

\section{Operations}

All times are local ship time (UTC -2.5 h). See Table T1 for coring summary.

\section{Hole U1410A summary}

Latitude: $41^{\circ} 19.6987^{\prime} \mathrm{N}$

Longitude: $49^{\circ} 10.1995^{\prime} \mathrm{W}$

Water depth below sea level (m): 3387.5

Date started: 1845 h, 20 July 2012

Date finished: 0500 h, 22 July 2012

Time on hole (days): 1.4

Seafloor depth (m drilling depth below rig floor [DRF]): 3399.0

Seafloor depth estimation method: mudline core

Rig floor to sea level (m): 11.75

Penetration depth ( $\mathrm{m}$ drilling depth below seafloor [DSF]): 259.8

Cored interval (m): 259.8

Recovered length (m): 256.88

Recovery (\%): 99

Total cores (number): 28

APC cores (number): 16

$\mathrm{XCB}$ cores (number): 12 
Drilling system: 11\%16 inch advanced piston corer (APC)/extended core barrel (XCB) bit with $136.00 \mathrm{~m}$ bottom-hole assembly (BHA)

Objective: core from seafloor to $250 \mathrm{~m}$ DSF or until science objectives are met

Result: target reached; objectives achieved

\section{Hole U1410B summary}

Latitude: $41^{\circ} 19.6993^{\prime} \mathrm{N}$

Longitude: $49^{\circ} 10.1847^{\prime} \mathrm{W}$

Water depth below sea level (m): 3386.92

Date started: 0500 h, 22 July 2012

Date finished: 1620 h, 23 July 2012

Time on hole (days): 1.5

Seafloor depth (m DRF): 3398.7

Seafloor depth estimation method: mudline core

Rig floor to sea level (m): 11.78

Penetration depth (m DSF): 245.2

Cored interval (m): 245.2

Recovered length (m): 244.84

Recovery (\%): 100

Total cores (number): 28

APC cores (number): 18

$\mathrm{XCB}$ cores (number): 10

Drilling system: 11\%16 inch APC/XCB bit with $136.00 \mathrm{~m}$ BHA

Objective: core from seafloor to $250 \mathrm{~m}$ DSF

Result: target reached; objectives achieved

\section{Hole U1410C summary}

Latitude: $41^{\circ} 19.6885^{\prime} \mathrm{N}$

Longitude: $49^{\circ} 10.1854^{\prime} \mathrm{W}$

Water depth below sea level (m): 3386.9

Date started: 1620 h, 23 July 2012

Date finished: 0915 h, 25 July 2012

Time on hole (days): 1.7

Seafloor depth (m DRF): 3398.7

Seafloor depth estimation method: mudline core

Rig floor to sea level (m): 11.78

Penetration depth (m DSF): 243.8

Cored interval $(\mathrm{m}): 243.8$

Recovered length (m): 238.81

Recovery (\%): 98

Total cores (number): 27

APC cores (number): 16

$\mathrm{XCB}$ cores (number): 11

Drilling system: 11\%16 inch APC/XCB bit with $136.00 \mathrm{~m} \mathrm{BHA}$

Objective: repeat cored sequence from Hole U1410B

Result: target reached; objectives achieved

\section{Description}

The vessel arrived at Site U1410 at $1845 \mathrm{~h}$ on 20 July 2012 after a $3.46 \mathrm{nmi}$ transit from Site U1409 in dynamic positioning mode that took $3.5 \mathrm{~h}$ at $1.0 \mathrm{kt}$. The plan for Site U1410 called for drilling three holes to $250 \mathrm{~m}$ DSF. Holes U1410A, U1410B, and U1410C were successfully cored to $259.8,245.2$, and $243.8 \mathrm{~m}$ DSF, respectively. The total time spent at Site U1410 was $110.5 \mathrm{~h}$ (4.6 days).

\section{Hole U1410A coring}

A $8.53 \mathrm{~m}$ long mudline core established seafloor depth at $3399.0 \mathrm{~m}$ DRF (3387.3 mbsl). Hole U1410A was spudded at $2125 \mathrm{~h}$ on 20 July. Cores 342U1410A-1H through $16 \mathrm{H}$ were recovered to $151.0 \mathrm{~m}$ DSF using nonmagnetic core barrels and the FlexIT core orientation tool. Core $16 \mathrm{H}$ experienced the first partial stroke. The XCB was deployed for Cores 17X through 28X to the final depth of $259.8 \mathrm{~m}$ DSF. The seafloor was cleared at $0500 \mathrm{~h}$ on 22 July, ending Hole U1410A. Overall core recovery for Hole $\mathrm{U} 1410 \mathrm{~A}$ was $256.88 \mathrm{~m}$ for the $259.8 \mathrm{~m}$ interval cored (98.9\% recovery). The total time spent in Hole U1410A was $34.25 \mathrm{~h}$.

\section{Hole U1410B coring}

The vessel was offset $20 \mathrm{~m}$ east. A $3.8 \mathrm{~m}$ long mudline core established the seafloor at $3398.7 \mathrm{~m}$ DRF (3386.9 mbsl). Hole U1410B was spudded at $0650 \mathrm{~h}$ on 22 July. Cores $342-\mathrm{U} 1410 \mathrm{~B}-1 \mathrm{H}$ through $18 \mathrm{H}$ were recovered to $153.8 \mathrm{~m}$ DSF using nonmagnetic core barrels and the FlexIT core orientation tool. The XCB was deployed for Cores 19X through 28X to a final depth of $245.2 \mathrm{~m}$ DSF. The seafloor was cleared at 1620 h on 23 July, ending Hole U1410B. The overall recovery for Hole U1410B was $244.84 \mathrm{~m}$ over the $245.2 \mathrm{~m}$ cored (99.9\% recovery). The total time spent in Hole U1410B was $35.25 \mathrm{~h}$.

\section{Hole U1410C coring}

The vessel was offset $20 \mathrm{~m}$ south, and Hole U1410C was spudded at $1825 \mathrm{~h}$ on 23 July. A $6.82 \mathrm{~m}$ long mudline core established the water depth at $3398.7 \mathrm{~m}$ DRF (3386.9 mbsl). Cores 342-U1410C-1H through $16 \mathrm{H}$ were recovered to $146.8 \mathrm{~m}$ DSF using nonmagnetic core barrels. No core orientation was performed in Hole U1410C. The XCB was deployed for Cores $17 \mathrm{X}$ through $27 \mathrm{X}$ to a final depth of $243.8 \mathrm{~m}$ DSF. Overall recovery for Hole U1410C was $238.81 \mathrm{~m}$ out of $243.8 \mathrm{~m}$ cored (98.0\% recovery). The seafloor was cleared, and the vessel was secured for transit at $0915 \mathrm{~h}$ on 25 July, ending Hole U1410C. The total time spent on Hole U1410C was $41.00 \mathrm{~h}$. 


\section{Lithostratigraphy}

At Site U1410, we recovered an $\sim 260$ m thick sedimentary succession of deep-sea sediment of Pleistocene to early Eocene age. The full sequence of lithostratigraphic units was only recovered in Hole U1410A. Holes U1410B and U1410C were terminated at 244.25 and 243.27 meters below seafloor (mbsf), respectively.

The sedimentary sequence at Site U1410 comprises four lithostratigraphic units (Figs. F4, F5, F6, F7, F8, F9; Table T2). Unit I is an $\sim 34 \mathrm{~m}$ thick succession of Pleistocene sediment with alternating reddish brown clay, gray to dark brown muddy/clayey foraminiferal ooze with nannofossils, grayish brown foraminiferal sand, and occasional sand- to pebble-sized lithics (Fig. F5A, F5B). Unit II is an $\sim 30 \mathrm{~m}$ thick succession of clay, clay with nannofossils, and nannofossil clay of early Miocene to Oligocene age (Figs. F5C, F5D, F6B). Manganese, present as discrete nodules or disseminated silt- to sand-sized flecks, and disseminated sulfides are common. Sedimentological and biostratigraphic information indicates that Unit II contains multiple hiatal surfaces in addition to the unconformities that define its upper and lower boundaries. Middle to upper Eocene Unit III is the thickest of the four units (63-68 m thick) and contains greenish gray to greenish nannofossil clay to greenish clayey nannofossil ooze with distinctive $10-25 \mathrm{~cm}$ thick bands of light gray to white nannofossil ooze (Figs. F5E, F6C). Lithostratigraphic Unit IV is a $48 \mathrm{~m}$ thick sequence of white to pinkish white nannofossil chalk with foraminifers and/or radiolarians of early Eocene age (Figs. F5F, F5G, F6D). This unit is divided into two subunits, with the lower subunit containing several chert beds. Hole U1410A is the deepest hole and thus contains the thickest record of Unit IV. Coring in Hole U1410C recovered only $47 \mathrm{~cm}$ of the upper part of Subunit IVb. No part of Subunit IVb was recovered from Hole U1410B (Table T2).

Lithostratigraphic units and boundaries are defined by changes in lithology (as identified by visual core description and smear slide observations), physical properties, color reflectance $\left(\mathrm{L}^{*}, \mathrm{a}^{*}\right.$, and $\left.\mathrm{b}^{*}\right)$, and biogenic content (calcium carbonate and silica) (Fig. F4). The lithologic differences observed between units are primarily attributable to varying abundances of nannofossils, diatoms, radiolarians, and foraminifers (Figs. F7, F8, F9). Lithologic descriptions are based on sediment recovered from Hole U1410A and refined with observations from Holes U1410B and U1410C. The Unit I/II boundary is a sharp contact between banded brown to gray Pleisto- cene sediment and underlying greenish gray clay of late Miocene age. The basal boundary of Unit II is also sharp and corresponds to a temporal hiatus between overlying lower Oligocene clay and nannofossil clay and underlying middle Eocene sediment that alternates between white nannofossil ooze and dark green nannofossil clay. The Unit III/IV boundary is defined by the transition from alternating green nannofossil clay and white nannofossil ooze to pinkish white, carbonate-rich nannofossil ooze with foraminifers and radiolarians.

\section{Unit I}

Intervals: $342-\mathrm{U} 1410 \mathrm{~A}-1 \mathrm{H}-1,0 \mathrm{~cm}$, to $4 \mathrm{H}-5,85 \mathrm{~cm}$; $342-\mathrm{U} 1410 \mathrm{~B}-1 \mathrm{H}-1,0 \mathrm{~cm}$, to $5 \mathrm{H}-2,135 \mathrm{~cm} ; 342-$ U1410C-1H-1, $0 \mathrm{~cm}$, to $4 \mathrm{H}-5,87 \mathrm{~cm}$

Depths: Hole U1410A = 0-34.35 mbsf; Hole $\mathrm{U} 1410 \mathrm{~B}=0-34.15 \mathrm{mbsf}$; Hole $\mathrm{U} 1410 \mathrm{C}=0$ $32.67 \mathrm{mbsf}$

Age: Pleistocene

Lithology: nannofossil ooze to nannofossil foraminiferal ooze, silty clay with nannofossils or foraminifers, clay, and muddy foraminiferal sand

Unit I is an $\sim 34 \mathrm{~m}$ thick succession of Pleistocene sediment with reddish brown (5YR 5/3) to dark greenish gray (10Y 4/1) clay, gray (N6 and 10YR 5/1) and dark brown (5Y 4/2) to dark greenish gray (10Y 4/1) muddy/clayey foraminiferal ooze with nannofossils, and grayish brown $(2.5 \mathrm{Y} 5 / 2)$ foraminiferal sand (Fig. F5A, F5B). Sediment in the uppermost interval of Unit I ( 0 to $\sim 12 \mathrm{mbsf}$ ) contains radiolarians and diatoms of varying abundances (Figs. F6, F7, F8, F9). These siliceous components are found only in Units I and IV and further distinguish Unit I sediment from that of underlying Unit II. The upper half of Unit I ( 0 to $\sim 15 \mathrm{mbsf}$ ) contains discrete layers and patches of coarse sand- to small pebble-sized lithics, which are clearly ice-rafted debris. The sediment of Unit I is heavily to completely bioturbated throughout, with the exception of some sandy layers that are only slightly bioturbated. The Unit I/II boundary is defined by a sharp contact between brown and gray Pleistocene sediment and underlying greenish gray clay and dark greenish gray nannofossil clay of late Miocene age in the upper part of Unit II. This contact, which occurs in Cores 342-U1410A-4H, 342U1410B-5H, and 342-U1410C-4H ( 34 mbsf), is expressed as a decrease in magnetic susceptibility from $\sim 150$ instrument units (IU) in Unit I to <20-50 IU in Unit II (Fig. F4) and a decrease in bulk density (see "Physical properties"). Core 342-U1410C-4H contains a thin $(<5 \mathrm{~cm})$ interval of lithogenic sand that directly overlies a sharp contact. This is likely a winnowed deposit that formed during the $>5 \mathrm{~m}$.y. 
duration of the unconformity that separates Units I and II.

\section{Unit II}

Intervals: $342-\mathrm{U} 1410 \mathrm{~A}-4 \mathrm{H}-5,85 \mathrm{~cm}$, to $7 \mathrm{H}-7,62$ $\mathrm{cm}$; 342-U1410B-5H-2, $135 \mathrm{~cm}$, to $8 \mathrm{H}-4,7 \mathrm{~cm}$; $342-\mathrm{U} 1410 \mathrm{C}-4 \mathrm{H}-5,87 \mathrm{~cm}$, to $7 \mathrm{H}-7,24 \mathrm{~cm}$

Depths: Hole U1410A $=34.35-64.17$ mbsf; Hole $\mathrm{U} 1410 \mathrm{~B}=34.15-63.27$ mbsf; Hole U1410C = 32.67-63.54 mbsf

Age: late Miocene to Oligocene

Lithology: clay, clay with nannofossils, and nannofossil clay

Unit II is an $\sim 30 \mathrm{~m}$ thick succession of clay, clay with nannofossils, and nannofossil clay of late Miocene to Oligocene age (Fig. F4). Colors range from light olive-gray $(5 \mathrm{Y} 6 / 2)$ to olive-gray (5Y $6 / 2)$, greenish gray (10GY 5/1 and 10Y 6/1), and dark greenish gray (5G $4 / 1$ ) for the clay and greenish gray (5GY $5 / 1$ and $10 \mathrm{Y}$ $5 / 1$ ) to dark greenish gray (10GY 4/1) for the nannofossil clay (Fig. F5C, F5D). The abundance of foraminifers decreases substantially compared to overlying Unit I, and siliceous biogenic components are absent (Figs. F6, F7, F8, F9). Minor lithologies and accessories include centimeter-scale manganese nodules, disseminated manganese as small dark flecks, dark green glauconite-rich horizons, and dark gray to black concentrations of sulfides. Sulfide mineralization is typically associated with burrows, creating a mottled appearance. Small $(1 \mathrm{~mm}$ to $<1 \mathrm{~cm})$ concentrations of angular, silt- to very fine sand-sized quartz (confirmed by shipboard X-ray diffraction [XRD] analysis) are present throughout Unit II as discrete patches/blebs or, more rarely, as discontinuous lenses within the nannofossil clay (Figs. F5D, F10). We hypothesize that this angular quartz is ice-rafted debris that was subsequently reworked and concentrated by bioturbation.

Sharp contacts define the upper and lower stratigraphic boundaries of Unit II in all holes and coincide with abrupt changes in color and lithology (Fig. F4). Additionally, prominent surfaces within Unit II typically associated with sediment containing abundant glauconite and/or manganese directly below are observed separating distinct intervals. For example, a sharp surface at Section 342-U1410A-5H-4, $43 \mathrm{~cm}$, separates overlying upper Miocene nannofossil clay from underlying lower Miocene nannofossil clay with silt. Although the lithologies across this surface are generally similar, there is a temporal gap of as much as 7 m.y. (see "Biostratigraphy"). Additional surfaces within Unit II likely represent other hiatuses that further biostratigraphic investigation could potentially resolve.

\section{Unit III}

Intervals: $342-\mathrm{U} 1410 \mathrm{~A}-7 \mathrm{H}-7,62 \mathrm{~cm}$, to $23 \mathrm{X}-1,150$ $\mathrm{cm}$; $342-\mathrm{U} 1410 \mathrm{~B}-8 \mathrm{H}-4,7 \mathrm{~cm}$, to $25 \mathrm{X}-\mathrm{CC}, 35 \mathrm{~cm}$; $342-\mathrm{U} 1410 \mathrm{C}-7 \mathrm{H}-7,24 \mathrm{~cm}$, to $23 \mathrm{X}-\mathrm{CC}, 37 \mathrm{~cm}$

Depths: Hole U1410A $=64.17-211.50$ mbsf; Hole $\mathrm{U} 1410 \mathrm{~B}=63.27-216.27$ mbsf; Hole U1410C = 63.54-214.22 mbsf

Age: middle Eocene

Lithology: nannofossil clay, clayey nannofossil ooze, and nannofossil ooze

Unit III is a $63-68 \mathrm{~m}$ thick succession of predominantly dark greenish gray (5GY 5/1) to greenish gray (10Y 5/1 and 10Y 6/1) nannofossil clay to greenish gray clayey nannofossil ooze (Figs. F4, F5E, F6B, F6C, F7, F8, F9). Distinctive $10-25 \mathrm{~cm}$ thick bands of light gray (10Y $7 / 1$ and $10 Y$ 8/1) to white (N 8) nannofossil ooze occur as a secondary, interbedded lithology (Figs. F5E, F6B, F6C). The white nannofossil ooze and greenish gray clay are differentiated by physical properties including color reflectance $\left(\mathrm{L}^{*}\right)$, magnetic susceptibility, natural gamma radiation (NGR) (Fig. F11), and carbonate content, which varies from $\sim 30 \mathrm{wt} \%$ in the dark layers to $\sim 80 \mathrm{wt} \%$ in the light layers (Fig. F4). The frequency of the lighter colored, more nannofossil rich bands is variable throughout Unit III, with some cores containing no light-colored bands and other cores displaying a strikingly rhythmic banded appearance (e.g., Core 342-U1410A-12H; Fig. F11). Intervals of alternating greenish gray nannofossil clay and white nannofossil ooze of middle Eocene age were also recovered at Southeast Newfoundland Ridge Sites U1407 and U1408, all in Unit III. A similar succession, although diminished in its visual appearance, was also recovered in Oligocene-Miocene age sediment at J-Anomaly Ridge (e.g., Site U1405).

Bioturbation is moderate to heavy throughout Unit III, with Zoophycos, Planolites, and Chondrites burrows mottling both the greenish gray and white sediment. Green horizons with elevated concentrations of glauconite and chlorite occur throughout the light greenish gray beds of Unit III, but these are conspicuously absent from the white nannofossil oozes. The concentration of green horizons is higher in the uppermost portion of the light greenish gray nannofossil clay intervals immediately underlying the white/ green contacts.

Section 342-U1410A-17X-2 contains a $14 \mathrm{~cm}$ thick (153.13-153.27 mbsf) conglomerate with foraminiferal sand matrix (Fig. F12). The clasts are 0.5 to $>5$ $\mathrm{cm}$ in size and composed of the dominant nannofossil clay and clayey nannofossil ooze lithology that is observed throughout Unit III. Examination of calcareous nannofossils sampled from a clast and from the 
foraminiferal sand matrix indicates an age of nannofossil Subzone NP15b (middle Eocene) for both (see "Biostratigraphy"), which is consistent with the age of the sediment directly under and overlying the conglomerate bed (Fig. F12). We interpret the conglomerate to record erosion, reworking, and winnowing during a period of intensified bottom-current energy. The conglomerate bed in Section 342U1410A-17X-2 is overlain by an $\sim 11 \mathrm{~m}$ thick, internally chaotic interval containing several sharp surfaces, commonly at high angles, that juxtapose lighter clayey nannofossil ooze against darker nannofossil clay. This interval is similar in sedimentary characteristics and age (calcareous nannofossil Subzone NP15b) to an interpreted slump deposit in nearby Site U1409 (see Fig. F16 in the "Site U1409" chapter [Norris et al., 2014d]). Erosion and reworking during the phase that created the conglomerate lag deposit could have produced a relatively rough seafloor topography, which subsequently promoted mass wasting and other soft-sediment deformation in the overlying deposits.

The Unit III/IV boundary is defined by the transition from interbedded gray and white nannofossil clay and ooze to pinkish white, carbonate-rich nannofossil chalk with foraminifers and white nannofossil chalk with radiolarians. The carbonate content of sediments decreases at the Unit III/IV boundary from an average of $\sim 90 \mathrm{wt} \%$ in Unit IV to an average of $\sim 50 \mathrm{wt} \%$ in Unit III.

\section{Unit IV}

Intervals: $342-\mathrm{U} 1410 \mathrm{~A}-23 \mathrm{X}-2,0 \mathrm{~cm}$, through $28 \mathrm{X}-$ CC, $58 \mathrm{~cm}$; 342-U1410B-26X-1, $0 \mathrm{~cm}$, through 28X-CC, $32 \mathrm{~cm}$; 342-U1410C-24X-1, $0 \mathrm{~cm}$, through $27 \mathrm{X}-1,47 \mathrm{~cm}$

Depths: Hole U1410A = 211.50- 258.91 mbsf; Hole $\mathrm{U} 1410 \mathrm{~B}=225.49-244.25 \mathrm{mbsf}$; Hole U1410C = 214.00-243.27 mbsf

Age: early Eocene

Lithology: nannofossil chalk with foraminifers and/or radiolarians

Unit IV is a $48 \mathrm{~m}$ thick sequence of dominantly nannofossil chalk with foraminifers and/or radiolarians of early Eocene age. Unit IV is divided into two lithologically similar subunits on the basis of the occurrence of interbedded chert at $245.07 \mathrm{mbsf}$ in Hole U1410A (Fig. F4). The chert-rich Subunit IVb was recovered only in Hole U1410A. Unit IV is distinguished from overlying Unit III primarily by the abrupt change in lithology from greenish gray nannofossil clay to white nannofossil chalk, a change that is apparent in most physical property measurements (see "Physical properties"). A significant increase in siliceous biogenic components, especially radiolarians, further distinguishes Unit IV from overlying Unit III, which is essentially barren of siliceous microfossils (Figs. F6, F7, F8, F9).

\section{Subunit IVa}

Intervals: $342-\mathrm{U} 1410 \mathrm{~A}-23 \mathrm{X}-2,0 \mathrm{~cm}$, through $26 \mathrm{X}-$ $6,47 \mathrm{~cm} ; 342-\mathrm{U} 1410 \mathrm{~B}-26 \mathrm{X}-1,0 \mathrm{~cm}$, through 28X-CC, $32 \mathrm{~cm} ; 342-U 1410 \mathrm{C}-24 \mathrm{X}-1,0 \mathrm{~cm}$, through 26X-CC, $39 \mathrm{~cm}$

Depths: Hole U1410A = 211.50-245.07 mbsf; Hole $\mathrm{U} 1410 \mathrm{~B}=225.49-244.25$ mbsf; Hole U1410C = 214.22-239.83 mbsf

Age: early Eocene

Lithology: nannofossil chalk with foraminifers and/or radiolarians

Subunit IVa is a $20-34 \mathrm{~m}$ thick succession of white (N8) to pinkish white (7.5YR 8/2 and 7.5YR 8/3) nannofossil chalk with foraminifers and radiolarians (Fig. F5F). Subtle changes in color, from pinkish white to reddish brown (5YR 4/3), occur at the centimeter to decimeter scale in some parts of the succession. Intervals of slightly brighter pink nannofossil chalk are more abundant in radiolarians. Heavy bioturbation, evidenced by faint mottling, occurs throughout Subunit IVa. Underlying Subunit IVb is distinguished by the first occurrence of chert.

\section{Subunit IVb}

Intervals: $342-\mathrm{U} 1410 \mathrm{~A}-26 \mathrm{X}-6,47 \mathrm{~cm}$, through 28X-CC, $58 \mathrm{~cm}$; 342-U1410C-27X-1, $0 \mathrm{~cm}$; through $27 \mathrm{X}-1,47 \mathrm{~cm}$

Depths: Hole U1410A = 245.07-258.91 mbsf; Hole $\mathrm{U} 1410 \mathrm{C}=242.80-243.27 \mathrm{mbsf}$

Age: early Eocene

Lithology: nannofossil chalk with foraminifers and/or radiolarians and chert

Subunit IVb is a $14 \mathrm{~m}$ thick nannofossil chalk with foraminifers and/or radiolarians distinguished from Subunit IVa by several thin $(<5 \mathrm{~cm})$ brown $(7.5$ YR $6 /$ 4) chert layers. Coring of Subunit IVb in Holes U1410B and U1410C was not attempted because of the significantly slower drilling encountered in Hole $\mathrm{U} 1410 \mathrm{~A}$ as a result of the chert layers. The brief recovery of this subunit in Hole U1410C is incidental.

\section{Summary}

The sedimentary sequence at Site U1410 comprises four lithostratigraphic units. Unit I is an $\sim 34 \mathrm{~m}$ thick succession of Pleistocene sediment with alternating reddish brown clay, gray to dark brown muddy/clayey foraminiferal ooze with nannofossils, grayish brown foraminiferal sand, and occasional sand- to pebblesized lithics (Fig. F5A, F5B). Unit II is an $\sim 30 \mathrm{~m}$ thick succession of clay, clay with nannofossils, and nan- 
nofossil clay of late Miocene to Oligocene age (Fig. F5C, F5D). Manganese, present as discrete nodules or disseminated silt- to sand-sized flecks, and disseminated sulfides are common. Sedimentological and biostratigraphic information indicates that Unit II contains multiple hiatal surfaces in addition to the unconformities that define its upper and lower boundaries. Middle to lower Eocene Unit III is the thickest of the four units $(63-68 \mathrm{~m})$ and contains greenish gray to greenish nannofossil clay and greenish clayey nannofossil ooze with distinctive $10-25 \mathrm{~cm}$ thick bands of light gray to white nannofossil ooze (Fig. F5E). Unit IV is a $48 \mathrm{~m}$ thick sequence of white to pinkish white nannofossil chalk with foraminifers and/or radiolarians of middle Eocene to early Eocene age. This unit is divided into two generally similar subunits, with the lower subunit containing several chert beds.

The lithostratigraphy of Site U1410 strongly resembles that of Sites U1408 and U1409 in terms of the appearance, lithology, degree of bioturbation, and sedimentary succession of units for Units I-III and, to a lesser degree, Unit IV. We observed three lithostratigraphic commonalities among all sites drilled to date on the Southeast Newfoundland Ridge (Sites U1407-U1410). They include

1. Cyclic banding between light greenish gray nannofossil clay and white (or lighter greenish gray) nannofossils ooze of middle Eocene age,

2. Cherts and other silicified sediments in the lower Eocene, and

3. A step change in calcium carbonate content in sediment during nannofossil Zone NP14 (around the lower to middle Eocene boundary).

\section{Biostratigraphy}

Coring at Site U1410 recovered a $260 \mathrm{~m}$ thick sequence of Pleistocene to lower Eocene nannofossil ooze and nannofossil clay, with foraminifers and radiolarians. Nannofossils, planktonic foraminifers, and benthic foraminifers are present through most of the succession. Short barren intervals occur between thin Pleistocene, upper Miocene, and lower Miocene-Oligocene sequences. Radiolarians are only present in the uppermost Pleistocene and lower Eocene. Thin Pleistocene, upper Miocene, and lower Miocene-Oligocene sequences overlie a middle Eocene through lower Eocene succession. Hiatuses or highly condensed intervals occur between the lower Pleistocene and upper Miocene (7.1 m.y. duration), upper and lower Miocene (7.4 m.y. duration), lower Miocene and upper Oligocene (5.4 m.y. duration), and lower Oligocene and middle Eocene (7.4 m.y. duration). The Oligocene is highly condensed and may also contain significant hiatuses. Sedimentation rates are $0.2 \mathrm{~cm} / \mathrm{k} . \mathrm{y}$. through the Oligocene, 1.3-2.6 $\mathrm{cm} / \mathrm{k} . \mathrm{y}$. through the middle Eocene, and $0.6 \mathrm{~cm} / \mathrm{k} . \mathrm{y}$. through the lower Eocene.

Benthic foraminifers are generally rare (the "present" category) throughout the recovered succession with the exception of the Miocene to Oligocene, in which they are abundant to dominant. Benthic foraminifer preservation is good to very good through most of the recovered Eocene sequence. Moderate to poor preservation occurs in the Miocene to Oligocene and the early Eocene.

An integrated calcareous and siliceous microfossil biozonation is shown in Figure F13. An age-depth plot including biostratigraphic and paleomagnetic datums is shown in Figure F22. Datum and zonal determinations from nannofossils, planktonic foraminifers, and radiolarians are in close agreement. Microfossil and paleomagnetic datums are given in Table T3. A summary of calcareous and siliceous microfossil abundances and preservation is given in Figure F14.

\section{Calcareous nannofossils}

Calcareous nannofossil biostratigraphy is based on analysis of core catcher and additional working section-half samples in Hole U1410A. Depth positions and age estimates of biostratigraphic marker events are shown in Table T4. Calcareous nannofossil occurrence data are shown in Table T5. Note that the distribution charts are based on shipboard study only and are therefore biased toward age-diagnostic species.

At Site U1410, the preservation of calcareous nannofossils is generally good and moderate to good in the middle Eocene and moderate in the upper Miocene, lower Miocene-Oligocene, and lower Eocene. The uppermost sediment in Hole U1410A contains abundant nannofossils indicative of Pleistocene Zones NN20/NN21-NN17 indicated by the top of Pseudoemiliania lacunosa in Sample 342-U1410A-1H-CC (8.48 mbsf) and the top of Discoaster pentaradiatus in Sample 4H-3, $100 \mathrm{~cm}$ (31.51 mbsf). Samples 4H-3, $100 \mathrm{~cm}$ (31.51 mbsf), through 4H-CC (37.52 mbsf) are noncalcareous and do not contain nannofossils. The short interval from Sample $4 \mathrm{H}-\mathrm{CC}$ to $5 \mathrm{H}-3,100$ $\mathrm{cm}$ (31.51-41.00 mbsf), is assigned to upper Miocene Zone NN9 based on the presence of Discoaster hamatus. The underlying sediment, from Sample 5H-3, $100 \mathrm{~cm}$, to $5 \mathrm{H}-\mathrm{CC}$ (41.00-46.45 mbsf), is noncalcareous and barren of nannofossils.

The interval from Sample 342-U1410A-5H-CC through $6 \mathrm{H}-5,50 \mathrm{~cm}(46.45-53.00 \mathrm{mbsf})$, is assigned to lower Miocene-upper Oligocene Zones NN3-NN1 
based on the top of Sphenolithus belemnos in Sample 5H-CC (46.45 mbsf), the base of Discoaster druggii in Sample $6 \mathrm{H}-3,50 \mathrm{~cm}$ (50.00 mbsf), and the top of Sphenolithus ciperoensis in Sample 6H-5, $50 \mathrm{~cm}$ (50.00 mbsf). A short, poorly preserved interval, from Sample $6 \mathrm{H}-5,50 \mathrm{~cm}$, through $7 \mathrm{H}-3,50 \mathrm{~cm}(50.00-59.55$ mbsf), is late Oligocene in age (Zones NP24-NP25) based on the presence of Dictyococcites bisectus and $S$. ciperoensis.

The identification of Zone NP23 in Sample 342U1410A-7H-7, $62 \mathrm{~cm}$ (64.17 mbsf), and Zone NP17 in Sample 342-U1410B-4H-CC, $6.5 \mathrm{~cm}$ (64.25 mbsf), indicates the presence of a hiatus of $\sim 8 \mathrm{~m}$.y., representing the upper Eocene to lower Oligocene.

Samples 342-U1410A-7H-7, $70 \mathrm{~cm}$, through 28X-CC (64.25-258.69 mbsf) are assigned to middle to upper Eocene nannofossil Zones NP17-NP12 based on the top of Chiasmolithus grandis in Sample 7H-7, $70 \mathrm{~cm}$ (64.25 mbsf), the top and base of Chiasmolithus gigas in Samples 17X-2, $87 \mathrm{~cm}$ (153.37 mbsf), and 21X-2, $70 \mathrm{~cm}$ (190.74 mbsf), the base of Blackites inflatus in Sample 23X-6, $108 \mathrm{~cm}$ (216.28 mbsf), the base of Discoaster sublodoensis in Sample 24X-CC (227.06 mbsf), the top of Tribrachiatus orthostylus in Sample 26X-5, $90 \mathrm{~cm}$ (244.00 mbsf), and the presence of Discoaster lodoensis at the base of the section in Sample 28X-CC (258.69 mbsf).

\section{Radiolarians}

Radiolarian biostratigraphy is based on analysis of all core catcher samples from Hole U1410A. No samples from Hole U1410B or U1410C were examined. Radiolarians are present in the uppermost part of Hole U1410A (Cores 342-U1410A-1H and 2H) but are absent from the underlying Pleistocene-middle Eocene interval, from Core $3 \mathrm{H}$ to $22 \mathrm{X}$ (27.88-208.03 mbsf). Radiolarians are very abundant and well preserved in the upper part of the lower Eocene (Cores 23X through 25X; 218.4-233.2 mbsf) and common but poorly preserved in the lowermost Cores 26X through 28X (246.1-258.7 mbsf). Depth positions and age estimates of biostratigraphic marker events are shown in Table T6, and the radiolarian distribution is shown in Table T7. Note that the distribution charts are based on shipboard study only and are therefore biased toward age-diagnostic species.

Sample 342-U1410A-1H-CC (8.48 mbsf) contains a well-preserved Pleistocene-Holocene radiolarian assemblage assigned to Zone RN17 based on the absence of Stylatractus universus. Sample 2H-CC (18.4 mbsf) contains rare radiolarians of no biostratigraphic utility. Samples 3H-CC through 22X-CC (20.6-208.03 mbsf) are barren of radiolarians.
Below 208.03 mbsf, Hole U1410A contains a continuous radiolarian succession from Zone RP11 to RP8. Sample 342-U1410A-23X-CC (218.4 mbsf) is assigned to Zone RP11 based on the presence of the primary index species Dictyomitra mongolfieri and the absence of Eusyringium lagena, the primary index species for Zone RP12. The scarcity of D. mongolfieri suggests that this sample lies in lowermost Zone RP11. Sample 24X-CC (227.1 mbsf) is assigned to Zone RP10 based on the presence of Lithochytris vespertilio and the absence of $D$. mongolfieri. The event that defines the base of Zone RP10, the faunal crossover from Theocotyle nigriniae to Theocotyle cryptocephala, is poorly expressed in Hole U1410A. T. cryptocephala is much less common than T. nigriniae in both samples that span the Zone RP10-RP11 interval. Sample 25X-CC (233.2 mbsf) is assigned to Zone RP9 based on the presence of Lamptonium fabaeforme constrictum and the absence of Lamptonium vespertilio and T. cryptocephala. Samples 26X-CC through 28XCC (246.1-258.7 mbsf) contain common radiolarians of poor to moderate preservation and are assigned to Zone RP8 based on the presence of the primary index, Buryella clinata. The top of Buryella tetradica is recorded at the top of the zone (Sample 26X-CC; 246.1 mbsf).

\section{Planktonic foraminifers}

Core catchers and additional samples from Hole U1410A working section halves were examined. Samples contain planktonic foraminifers from the Pleistocene through lower Eocene. Depth positions and age estimates of identified biostratigraphic marker events are shown in Table T8. The stratigraphic distribution of planktonic foraminifers is shown in Table T9.

The uppermost interval from Sample 342-U1410A1H-CC to 2H-CC (8.48-18.36 mbsf) contains Globorotalia truncatulinoides and Globorotalia inflata, indicative of Pleistocene age. Sections 342-U1410A-3HCC through 4H-5 (27.88-34.51 mbsf) contain a poorly preserved low-diversity assemblage dominated by G. inflata, Neogloboquadrina dutertrei, and Neogloboquadrina pachyderma, suggesting an age of late Pliocene-Pleistocene. An upper Miocene assemblage was recovered from Samples $4 \mathrm{H}-6,100-102 \mathrm{~cm}$, through 5H-3, 100-102 cm (36.01- $41.01 \mathrm{mbsf})$, with the co-occurrence of Globoturborotalita nepenthes, Globorotalia plesiotumida, and Sphaeroidinellopsis seminulina and the absence of Globorotalia tumida and Sphaeroidinella dehiscens, suggesting Subzone M13b to Zone M14.

Three barren intervals occur from Sample 342U1410A-5H-4, 100-102 cm, to $5 \mathrm{H}-5,100-102 \mathrm{~cm}$ 
(42.51-44.01 mbsf); from Sample 6H-6, 100-102 cm, to $6 \mathrm{H}-\mathrm{CC}$ (55.01-56.20 mbsf); and in Sample 7H-7, $28-30 \mathrm{~cm}$ (63.84 mbsf). Samples $5 \mathrm{H}-6,90-92 \mathrm{~cm}$, to $6 \mathrm{H}-4,100-102 \mathrm{~cm}$ (45.41-52.01 mbsf), contain no planktonic foraminifers or poorly preserved and impoverished assemblages of early Miocene age (Zone M3 or older) consisting of Catapsydrax dissimilis, Globorotalia praescitula, and Globigerinoides immaturus. A poorly preserved and impoverished assemblage of Oligocene age (unzoned) exists from Sample 7H-2, $100-102 \mathrm{~cm}$, to $7 \mathrm{H}-5,100-102 \mathrm{~cm}(58.53-61.9$ mbsf).

Sample 342-U1410A-7H-7, 100-102 cm, contains diverse globigerinathekids, Subbotina senni, Turborotalita carcoselleensis, and Turborotalia cerroazulensis, suggesting middle Eocene Zone E13. Well-preserved and diverse planktonic foraminifers of early to middle Eocene age are found in Samples 7H-CC through 23X-5, 102-104 cm (65.66-215.53 mbsf). The top and base of Orbulinoides beckmanni demarcates the top and base of Zone E12 in Samples 8H-4, 110-112 $\mathrm{cm}$, and 9H-CC (71.11-84.56 mbsf). The top of Guembelitrioides nuttalli marks the base of Zone E11 in Sample 10H-6, 90-92 cm (90.56 mbsf). Although the top of Morozovella aragonensis marks the base of Zone E10, this species occurs only sporadically through the middle Eocene of Hole U1410A. Therefore, we have used the base of Morozovella lehneri in Sample 17X-4, 120-122 cm (156.71 mbsf), to approximate this zonal boundary. The base of Globigerinatheka kugleri occurs in Sample 17X-CC (160.82 mbsf) and marks the base of Zone E9. The base of $G$. nuttalli in Sample 22X-2, 100-102 cm (201.51 mbsf) indicates the base of Zone E8, and the base of Turborotalia frontosa in Sample 23X-5, 102-104 cm (215.53 mbsf), marks the base of Subzone E7b.

The early Eocene interval from Sample 342-U1410A23X-CC to 27X-CC (218.43-255.14 mbsf) contains poorly preserved planktonic foraminifers ranging from Subzone E7a through Zone E5. The base of Acarinina cuneicamerata in Sample 26X-2, 114-115 cm (239.75 mbsf), indicates the base of Subzone E7a, whereas the top of Morozovella subbotinae in Sample 27X-CC (252.83 mbsf) marks the top of Zone E5.

\section{Benthic foraminifers}

Benthic foraminifers were examined semiquantitatively in core catcher samples from Hole U1410A. Additional working section half samples taken from Cores 342-U1410A-4H through 27X were examined for preservation and relative abundance of benthic foraminifers. Benthic foraminifers at this site are predominantly rare (the "present" category) relative to total sediment particles $>150 \mu \mathrm{m}$ in the Pleistocene and Eocene, and more abundant in the Miocene and Oligocene (Fig. F14; Tables T10, T11).

Preservation of benthic foraminifer tests is generally good to very good in the middle Eocene, the Miocene, and Oligocene, but the lower Eocene successions contain poorly to moderately preserved benthic foraminifers (Fig. F14).

With the exception of well-preserved Sample 342U1410A-1H-CC (8.48 mbsf), the Pleistocene faunas of Samples 1H-CC through 3H-CC (8.48-27.88 mbsf) are moderately preserved and dominated by Cibicidoides sp., Cibicidoides kullenbergi, Cibicidoides wuellerstorfi, Pullenia bulloides, Turrilina sp., and Uvigerina peregrina (Table T10).

The moderately preserved Miocene benthic foraminifer assemblage (Samples 342-U1410A-4H-CC and 5H-CC; 37.52-46.45 mbsf) is characterized by highproductivity fauna with abundant Cassidulina subglobosa, Dentalina sp., Gyroidinoides sp., Plectofrondicularia sp., Pleurostomella tenius, Stilostomella subspinosa, and Turrilina sp.

Poorly preserved Oligocene benthic foraminifers are found in Sample 342-U1410A-6H-CC (56.20 mbsf). This sample contains abundant glauconite grains and fish teeth, indicative of a condensed sequence with low sedimentation rate. Because of this condensed nature, benthic foraminifers, potentially exposed on the seafloor for a long interval of time, are severely fragmented and dissolved.

Samples 342-U1410A-7H-CC through 28X-CC (65.66-258.69 mbsf) show typical early to middle Eocene fauna dominated by calcareous taxa. Abundant calcareous taxa in the middle Eocene are Anomalinoides sp., Bulimina sp., Cassidulina subglobosa, Cibicidoides praemundulus, Dentalina sp., Nuttallides truempyi, Oridorsalis umbonatus, Pullenia bulloides, and stilostomellids (including Stilostomella gracillima, Stilostomella lepidula, and Stilostomella subspinosa) (Table T10). In addition to the taxa described above, the lower Eocene and lowermost middle Eocene (Samples 342-U1410A-21X-CC through 28X-CC; 199.13-258.69 mbsf) are characterized by the occurrence of Alabamina dissonata, Aragonia aragonensis, and Cibicidoides eocaenus.

The lower to middle Eocene assemblages described above suggest a normal deepwater environment, but Sample 342-U1410A-11H-CC (103.18 mbsf) is exceptional in that it contains a benthic foraminifer assemblage dominated by the infaunal taxa Bigenerina sp. and Stilostomella spp. together with abundant $N$. truempyi and lacks other epifaunal species. A shortterm increase in infaunal taxa can be also found within the MECO-equivalent sequence (Section 342- 
U1410A-8H-CC; $75.39 \mathrm{mbsf})$, comparable to observations from the same level at Site U1408.

\section{Paleomagnetism}

We completed a paleomagnetism study of APC and XCB cores from Holes U1410A-U1410C with the primary objective of establishing a magnetostratigraphic age model for the site. The natural remanent magnetization (NRM) of each archive section half was measured at $2.5 \mathrm{~cm}$ intervals before and after demagnetization treatment in a peak alternating field (AF) of $20 \mathrm{mT}$ for all cores from Hole U1410A. For all other cores, we only measured NRM after $20 \mathrm{mT}$ demagnetization. Archive-half measurement data were processed by removing measurements made within $7.5 \mathrm{~cm}$ of section ends and from disturbed intervals described in the Laboratory Information Management System database. Cores 342-U1410A$1 \mathrm{H}$ through $16 \mathrm{H}$ and $342-\mathrm{U} 1410 \mathrm{~B}-1 \mathrm{H}$ through $18 \mathrm{H}$ were azimuthally oriented using the FlexIT orientation tool (Table T12). All other cores were not oriented.

We also collected 178 discrete samples from working section halves to verify the archive section half measurement data and to measure anisotropy of magnetic susceptibility (AMS) and bulk susceptibility of Site U1410 sediment. Discrete samples were collected and stored in $7 \mathrm{~cm}^{3}$ plastic cubes and typically taken from the least disturbed region closest to the center of each section from Hole U1410A. Selected samples were subjected to measurements of AMS, including bulk susceptibility, and NRM after $20 \mathrm{mT}$ AF demagnetization. Twenty-two samples were selected for step-wise demagnetization at $0,10,20,30,40$, and $60 \mathrm{mT}$. All discrete sample data are volume corrected to $7 \mathrm{~cm}^{3}$.

\section{Results}

Downhole paleomagnetism data after $20 \mathrm{mT}$ demagnetization are presented for Holes U1410A, U1410B, and U1410C in Figures F15, F16, and F17, respectively. Similar to paleomagnetism results from previous Expedition 342 sites, section-half measurement data from cores recovered using the $\mathrm{XCB}$ are difficult to interpret because of biscuiting and substantial core disturbance. We chose to interpret only results obtained from APC cores except for a few cases in which discrete samples provide additional constraints on magnetozone identification in $\mathrm{XCB}$-recovered intervals.

We report the following principal features in the paleomagnetism data at Site U1410. First, we observed several trends in downhole magnetization intensity.
Second, inclinations are biased toward positive values, whereas declinations alternate around $180^{\circ}$ and cluster at $\sim 0^{\circ}$ and $\sim 180^{\circ}$. Third, the geomagnetic field transitions correlated to Chrons C18n.1nC18n.1r-C18n.2n are recorded in exceptional detail in Hole U1410B. The same reversal transitions were observed in similar detail at Site U1408; the two paleomagnetism records are remarkably coherent.

\section{Downhole trends in magnetic intensity}

Downhole magnetic intensity values show downhole trends that are consistent among all three holes and generally correspond to lithostratigraphic units. Magnetic intensity is invariant and high $\left(\sim 10^{-2} \mathrm{~A} / \mathrm{m}\right)$ in the uppermost $\sim 35 \mathrm{~m}$. This interval corresponds to the reddish brown to green Pleistocene nannofossil oozes, nannofossil and foraminifer oozes, and silty clay of lithostratigraphic Unit I (see "Lithostratigraphy"). From $\sim 40$ to $\sim 100 \mathrm{mbsf}$, magnetic intensity generally remains high $\left(\sim 10^{-2} \mathrm{~A} /\right.$ $\mathrm{m})$ but is distinguished from the interval above by frequent horizons of low magnetic intensity (as low as $\sim 10^{-4} \mathrm{~A} / \mathrm{m}$ ). This interval corresponds to the upper Miocene to Oligocene greenish gray clay and nannofossil clay of Unit II and the uppermost part of the middle Eocene green and greenish gray nannofossil clay and nannofossil ooze of Unit III. Although the contact between Units II and III is clearly distinguished by magnetic susceptibility, it is not obvious in the magnetic intensity record. From 100 to 150 mbsf, magnetic intensity gradually decreases from $10^{-2}$ to $10^{-4} \mathrm{~A} / \mathrm{m}$. This interval is entirely within Unit III. Below 150 mbsf, Holes U1410A and U1410B have two distinctive intervals that show gradual increases in intensity, from $\sim 10^{-5}$ to $\sim 10^{-4} \mathrm{~A} / \mathrm{m}$ at $\sim 150-220$ mbsf and from $\sim 10^{-5}$ to $\sim 10^{-3} \mathrm{~A} / \mathrm{m}$ below $\sim 220$ mbsf. In contrast, Hole U1410C shows almost constant intensity $\left(\sim 10^{-4} \mathrm{~A} / \mathrm{m}\right)$ below $\sim 150$ mbsf. Downhole trends in magnetic susceptibility below $\sim 150 \mathrm{mbsf}$ are similar among all three holes. The difference in downhole magnetic intensity trends among the three holes in this lowest interval is unclear, but it may be attributable to different degrees of core disturbance in these XCB-recovered intervals.

\section{Inclination bias and declination clustering}

Inclination bias indicates that there is a substantial drilling overprint even after $20 \mathrm{mT}$ AF demagnetization. Because of this strong inclination bias, we often cannot identify paleomagnetism polarity solely based on shipboard inclination data. However, azimuthally oriented APC cores show $\sim 180^{\circ}$ alternation of declination, and these values cluster at $\sim 0^{\circ}$ and $\sim 180^{\circ}$. We interpret intervals with declination values of $\sim 0^{\circ}\left(\sim 180^{\circ}\right)$ to indicate normal 
(reversed) magnetozones. A magnetozone with a primary normal polarity should not display inclinations less than $\sim 40^{\circ}$, barring sedimentary inclination shallowing biases. Notably, intervals with $\sim 180^{\circ}$ declination almost always correspond to inclination values that are more shallow than those in the intervals with declination of $\sim 0^{\circ}$. Thus, the drilling overprint mainly obscures remanent inclination but not declination, similar to the paleomagnetism results from Sites U1403 and U1404.

\section{Comparison between pass-through and discrete sample data}

AF demagnetization results for 109 discrete samples are summarized in Table T13. Of the 22 samples treated with a peak AF demagnetization field of 60 $\mathrm{mT}, 13$ reveal reasonably stable components of magnetization (e.g., Fig. F18A, F18B). These samples have remanent magnetizations that are strong enough to be measured by the onboard JR-6A spinner magnetometer. The remaining samples typically display NRM intensities that decrease by an order of magnitude following AF demagnetization in a $20 \mathrm{mT}$ field. This behavior indicates that a drilling overprint probably obscures the primary magnetic signal. An example of such a magnetic overprint can be seen in Figure F18C. Nevertheless, these results are useful for verifying the $20 \mathrm{mT}$ pass-through paleomagnetism data from the archive section halves.

Magnetization intensity and declination are generally consistent between the discrete samples and the archive section half samples from APCrecovered intervals (Fig. F15). In contrast, inclinations measured in discrete samples from XCB-recovered intervals are often more shallow than their counterpart values in the archive section half samples from APC core intervals. These observations indicate that cores from XCB-recovered intervals have a relatively severe overprint.

\section{Magnetostratigraphy}

The shipboard downhole results reveal a series of normal and reversed magnetozones between Cores 342-U1410A-1H and 24X ( 0-218 mbsf), between Cores 342-U1410B-1H and 15H ( 0-121 mbsf), and between Cores 342-U1410C-2H and 13H (13-118 mbsf). These magnetostratigraphies can be easily correlated among all three holes.

By utilizing radiolarian, foraminifer, and nannofossil biostratigraphic datums from Hole U1410A (see "Biostratigraphy"), we can correlate magnetozones to the geomagnetic polarity timescale (GPTS). The shipboard magnetostratigraphic age model is based on Hole U1410A, for which we have the most bio- stratigraphic datums. Extension of this age model to the magnetozonation observed in Holes U1410B and $\mathrm{U} 1410 \mathrm{C}$ is contingent on the accuracy of the stratigraphic correlation between holes, which is corroborated by lithostratigraphic horizons, biostratigraphic datums, and physical property features (see "Stratigraphic correlation"). Our correlation is presented in Table T14 and Figures F15, F16, F17, and F19.

We correlate the polarity transitions from the top of Core $342-\mathrm{U} 1410 \mathrm{~A}-1 \mathrm{H}$ to $4 \mathrm{H}$ at $\sim 32.95 \mathrm{mbsf}$ to Chron C1n (Brunhes) to upper Chron C2An.1n ( 2.6 Ma). We do not observe Chrons C2r.1r and C2r.1n (Réunion) in any hole at Site U1410 in this interval. We do not interpret this as a hiatus, but rather the inability of the wide-bore pass-through magnetometer to resolve these extremely short and rarely observed chrons in this Pleistocene sediment. We correlate the well-resolved magnetozonation observed in Sections 342-U1410A-8H-3 ( 68.68 mbsf) to $24 \mathrm{X}-1$ ( 218.06 mbsf) to lower Chron C18n.1n ( $39.5 \mathrm{Ma})$ continuously downhole to upper Chron C21r ( 47.4 $\mathrm{Ma})$. Paleomagnetism data from archive section halves and discrete samples suggest a magnetostratigraphy can be developed in deeper intervals at Site U1410, but it cannot be resolved in sufficient detail with these shipboard data to correlate with confidence to the GPTS. Magnetozone correlations for Holes U1410B and U1410C are similar to Hole U1410A, with the exceptions that we did not interpret XCB-recovered intervals in the former holes and we did not observe the Chron 18n.1r/18n.2n boundary in Hole U1410C.

The correlations described above provide a shipboard chronostratigraphic framework for interpreting the Pleistocene and middle Eocene sediment record at Site U1410. The most salient implications of this age model are that

- Average linear sedimentation rates during the Pleistocene at Site U1410 range from 1.47 to $2.35 \mathrm{~cm} / \mathrm{k} . y$. (Fig. F22),

- The difficulty in correlating magnetozones between Cores 342-U1410A-5H and 7H to the GPTS can be attributed to the highly condensed nature of this interval and the likelihood of several significant hiatuses inferred from the nannofossil biostratigraphy, and

- Average linear sedimentation rates during the middle Eocene at Site U1410 are similar to those calculated for Sites U1407-U1409. Sedimentation rates are highest during Chron C20n $(2.63 \mathrm{~cm} / \mathrm{k} . \mathrm{y}$. from $\sim 42.3$ to $43.4 \mathrm{Ma})$ and are $\sim 75 \%$ lower before and after this interval. Notably, the interval of highest average linear sedimentation rate (LSR) at Site U1410 is one chron 
younger than at Site U1409, the downslope conjugate site to Site U1410.

\section{Detailed record of a geomagnetic field transition}

At Site U1408, we found that the geomagnetic field transitions from Chrons C18n.1n to C18n.1r to C18n.2n are recorded in exceptional detail in all three holes over $\sim 7 \mathrm{~m}$ of stratigraphic section. A very similar record is observed between $\sim 67$ and $74 \mathrm{mbsf}$ in Hole U1410B (Fig. F20). The remarkable coherence in the record between the two distant sites suggests that the paleomagnetism record faithfully reflects geomagnetic field behavior rather than diagenetic artifacts. A thorough, shore-based paleomagnetism and rock magnetic study is necessary, however, to fully characterize and understand the geomagnetic field transition behavior.

\section{Magnetic susceptibility and anisotropy of magnetic susceptibility}

Bulk magnetic susceptibility measured on 118 discrete samples is summarized in Table T15. Although discrete samples were collected from each core section from the entire depth of Hole U1410A, we chose to measure only odd-numbered samples, except in the interval between Cores 342-U1410A-8H and $16 \mathrm{H}$, in which we measured every sample. Downhole variation in whole-round magnetic susceptibility (WRMS) and discrete sample magnetic susceptibility (DSMS) for Hole U1410A are shown in Figure F15. The WRMS data for Hole U1410A are shown in raw form; they have not been trimmed at section ends or filtered for obvious outliers, so noise in the data probably reflects edge effects or spurious measurements. We multiplied the WRMS data, which are in instrument units, by a factor of $0.577 \times 10^{-5}$ to convert to approximate SI volume susceptibilities (see "Paleomagnetism" in the "Methods" chapter [Norris et al., 2014a]). WRMS and DSMS data agree very well after this conversion, and we attribute small absolute differences to the fact that the conversion factor applied to the WRMS data is not constant downhole because of changes in core diameter and density; only discrete samples provide calibrated susceptibility values in SI units. Both magnetic susceptibility data sets show the same first- and second-order cyclic trends, indicating that these trends are robust features of Site U1410 sediment.

AMS results for the discrete samples are also summarized in Table T15 and are shown in Figure F21. The eigenvalues associated with the maximum $\left(\tau_{1}\right)$, intermediate $\left(\tau_{2}\right)$, and minimum $\left(\tau_{3}\right)$ magnetic susceptibilities at Site U1410 show some downhole varia- tions that correspond to changes in lithostratigraphy. We also observe a change in AMS values at the transition from APC to XCB coring technologies, with greater consistent divergence between principal eigenvalues indicative of more oblate fabrics in the XCB cores. In the clay-dominated lithostratigraphic Unit III, we observed consistently steeper inclinations of the minimum principal eigenvector $\left(\mathrm{V}_{3}\right)$ in the $\mathrm{XCB}$-recovered interval, but we did not observe this trend in the nannofossil chalks of Unit IV. Thus, as expected, more lithified sediment is more resistant to coring-induced fabrics.

Triaxial fabrics are greatest and most variable in three discrete intervals: Cores 342-U1410A-1H, 17X, and $24 \mathrm{X}$. These intervals are also characterized by high degrees of anisotropy $(P)$ and stronger lineation fabrics. In Core $1 \mathrm{H}$, we attribute this behavior to the high pore water content and lack of lithification in these young sediments. Core $17 \mathrm{X}$ is at the base of the interval of highest average LSR (Chron 20n; see "Magnetostratigraphy") and in a highly disturbed interval described as a slump deposit (Fig. F12). Core $24 \mathrm{X}$ is characterized by a peak in bulk density values and a low in water content in the white nannofossil chalk of lithostratigraphic Subunit IVa (see "Physical properties").

\section{Age-depth model and mass accumulation rates}

At Site U1410, we recovered a $260 \mathrm{~m}$ thick sequence of Pleistocene to lower Eocene nannofossil ooze and nannofossil clay with foraminifers and radiolarians. A relatively thick Pleistocene section overlies a condensed upper Miocene-upper middle Eocene section, which is followed by an expanded middle through lower Eocene succession. Hiatuses or highly condensed intervals occur between the lower Pleistocene and upper Miocene (7.1 m.y. duration), upper and lower Miocene (7.4 m.y. duration), lower Miocene and upper Oligocene (5.4 m.y. duration), and lower Oligocene and middle Eocene (7.4 m.y. duration). The Oligocene is highly condensed and may also contain substantial hiatuses. Sedimentation rates are $0.2 \mathrm{~cm} / \mathrm{k} . \mathrm{y}$. through the Oligocene, 1.3-2.6 $\mathrm{cm} / \mathrm{k} . \mathrm{y}$. through the middle Eocene, and $0.7 \mathrm{~cm} / \mathrm{k} . \mathrm{y}$. through the lower Eocene.

Biostratigraphic and magnetostratigraphic datums from Hole U1410A (Table T3) were compiled to construct an age-depth model for this site (Fig. F22). A selected set of datums (Table T16) was used to create an age-depth correlation and calculate LSRs. Total mass accumulation rate (MAR), carbonate MAR (CAR), and noncarbonate MAR (nCAR) were calcu- 
lated at 0.2 m.y. intervals using a preliminary shipboard splice rather than the sampling splice described in this volume (Table T17; Fig. F23).

\section{Age-depth model}

The age-depth model is tied to Pleistocene nannofossil and paleomagnetic datums in the upper $36 \mathrm{~m}$ of Hole U1410A. Nannofossil datums provide the sole tie points over a very condensed section that extends from the lower Pleistocene to the middle Eocene. This section includes two definite hiatuses and three very condensed intervals that probably also include hiatuses. Through the middle Eocene, nannofossil and paleomagnetic datums provide the primary tie points, with a single radiolarian datum serving as the final tie point in the core. Datums are in good agreement through the Eocene.

\section{Linear sedimentation rates}

This site is unique among sites drilled during this expedition in that it has a relatively expanded Pleistocene section with LSRs of $1.47-2.35 \mathrm{~cm} / \mathrm{k} . \mathrm{y}$. This section is followed downhole by a condensed Pliocenemiddle Eocene section with an average LSR of 0.19 $\mathrm{cm} / \mathrm{k} . \mathrm{y}$. The middle to lower Eocene section has high LSRs in the upper part $(1.98-2.63 \mathrm{~cm} / \mathrm{k} . \mathrm{y}$.) that decrease progressively to a minimum of $0.66 \mathrm{~cm} / \mathrm{k} . \mathrm{y}$. in the lower Eocene.

\section{Mass accumulation rates}

The Pleistocene sequence at Site U1410 has a MAR of 2.0 to $2.4 \mathrm{~g} / \mathrm{cm}^{2} / \mathrm{k} . \mathrm{y}$., with a double peak largely driven by the LSR pattern. MAR is low in the Pliocene to middle Oligocene with a pattern of peak MAR values that correspond to changes in LSR. In the middle Eocene, MAR is $2.0-2.9 \mathrm{~g} / \mathrm{cm}^{2} / \mathrm{k} . \mathrm{y}$., with roughly equal accumulation rates for carbonate and noncarbonate units. In the lower Eocene, carbonate contents increase to $\sim 90 \mathrm{wt} \%$, but overall MAR are significantly lower than the middle Eocene, with very low nCAR values.

\section{Geochemistry}

The geochemistry program during operations at Site U1410 included

- Analysis of interstitial gas compounds on headspace samples;

- Measurement of minor and trace element concentrations in interstitial water squeezed from whole-round samples from Hole U1410A;

- Inorganic carbon, total carbon, and total nitrogen determinations of solid sediment samples from multiple holes; and
- Characterization of organic matter by source rock pyrolysis.

\section{Headspace gas samples}

Headspace gas samples for routine safety monitoring were collected typically at a frequency of one sample per core in Hole U1410A (Table T18), generally in the bottom half of each core (i.e., Sections 4, 5, or 6). Methane increases very slightly downhole, with values between 2.11 and 6.72 ppmv. Higher molecular weight hydrocarbons were not detected in measurable amounts.

\section{Interstitial water samples}

Twenty-three interstitial water samples were squeezed from whole-round samples, which were typically taken at a frequency of one per core in Hole U1410A (Table T19). Whole-round samples were collected immediately after the cores were sectioned on the catwalk. In some cases, disturbed cores or low recovery precluded whole-round sampling, as in the case with Cores 342-U1410A-10H and 22X, which were too disturbed.

\section{Results}

Salinity, pH, alkalinity, ammonium, manganese, iron, and sulfate

The $\mathrm{pH}$ profile decreases uniformly throughout the hole from $~ 7.5$ at the seafloor to 6.8 at $254 \mathrm{mbsf}$ (Fig. F24). The salinity profile is near uniform at 36-38. In contrast, alkalinity shows low values of $\sim 3.5 \mathrm{mM}$ at the core top to $5.6 \mathrm{mM}$ at the base of lithostratigraphic Subunit IVb (254 mbsf).

Manganese concentrations display a complex profile, with values of $\sim 4-8 \mu \mathrm{M}$ in lithostratigraphic Units I and II (0-130 mbsf), a maximum of $\sim 15 \mu \mathrm{M}$ near the base of Unit III (190 mbsf), and values varying between 11 and $4 \mu \mathrm{M}$ in underlying Subunits IVa and IVb (220-254 mbsf).

Sulfate concentrations decrease downhole from a maximum of $30 \mathrm{mM}$ at the top of the recovered sequence (lithostratigraphic Unit I) to $<22 \mathrm{mM}$ at the base. Ammonium concentrations are highly variable but are lowest at the core top $(40 \mu \mathrm{M})$ and highest at the base $(155 \mu \mathrm{M})$ in Subunit IVb (254 mbsf). An intermediate maximum of $105 \mu \mathrm{M}$ occurs in Unit I (15 mbsf) and in the middle of Unit III $(120 \mu \mathrm{M}$ at 130 mbsf).

\section{Calcium, magnesium, sodium, chloride, boron, and potassium}

Calcium concentrations in Hole U1410A show an increasing downhole trend, from lithostratigraphic 
Unit I through Subunit IVb (0-254 mbsf), in which a step increase from $\sim 11$ to $\sim 24 \mathrm{mM}$ occurs.

Magnesium concentrations mirror the calcium profile, which shows slightly decreasing values in Unit I through Subunit IVa where a step decrease from 54 to $39 \mathrm{mM}$ occurs. Magnesium/calcium ratios show a smooth monotonic decline from $\sim 4.9$ at the core top to $<2$ at the base of the hole. Potassium concentrations show a decreasing downhole trend to a depth of 150 mbsf. Below this depth, the concentration profile is near uniform at $\sim 11 \mathrm{mM}$.

Sodium concentrations range from 465 to $494 \mathrm{mM}$, with a weak overall increasing downhole trend. Chloride concentrations range from 535 to $580 \mathrm{mM}$, with no discernible downhole trend.

Interstitial water boron concentrations are low $(\sim 400$ $\mu \mathrm{M}$ or less) at the core top and in lithostratigraphic Subunit VIa (220-240 mbsf) but rise to values between 450 and $580 \mu \mathrm{M}$ in Unit II (30 mbsf) and Subunit IVa (210 mbsf). Otherwise, boron concentrations show a gentle decline downhole.

\section{Discussion}

The interstitial fluid profiles of sulfate, alkalinity, and ammonium in Hole U1410A reflect typical changes associated with organic carbon cycling. As with other sites drilled to date on Southeast Newfoundland Ridge (Sites U1407-U1409), interstitial water profiles display evidence of compartmentalization with pronounced abrupt downhole shifts in magnesium, manganese, and potassium at $~ 220-230$ mbsf, suggesting that the unrecovered sequence of chert functions as an aquiclude. Overall, interstitial water profiles of potassium, calcium, and magnesium are consistent with those resulting from exchange with and alteration of basaltic basement at depth (Gieskes and Lawrence, 1981). Potassium and magnesium concentrations decrease and calcium concentrations increase with depth (Fig. F24). Inflections at $\sim 240$ mbsf correspond to an increase in alkalinity and indicate possible dissolution/reprecipitation of carbonate, which is high in the nannofossil chalk that comprises the basal lithostratigraphic Subunit IVb (see "Lithostratigraphy").

Depth profiles of alkalinity and manganese concentrations are well correlated with each other. This covariation of alkalinity and manganese concentrations indicates modest organic matter degradation associated with manganese reduction. Alkalinity, manganese, and iron show multiple peaks through the recovered sequences, which implies the presence of complex diffusional processes and organic matter reservoirs and subsequent organic matter degradation in each peak. Peak concentrations of manganese
$(16 \mu \mathrm{M})$ and iron $(80 \mu \mathrm{M})$ are attained in lithostratigraphic Unit III. Disseminated pyrite formation in Unit II is reflected in the low iron content $(0-4 \mu \mathrm{M})$, indicating syndepositional removal under highly reducing conditions. Both redox-sensitive metals not only reflect the generally reducing character of the sediment but also the difference between the clay contents of Unit III and the rest of the remaining units (see "Lithostratigraphy"). Sulfate concentrations steadily decrease with depth suggesting diffusion of seawater sulfate rather than solely microbial sulfate reduction.

The boron profile shows low values $(380 \mu \mathrm{M})$ in the top of the sedimentary section (0-30 mbsf) and then increases sharply to high values $(500-600 \mu \mathrm{M})$ at 3040 mbsf, from where values decrease downhole back to low levels $(400 \mu \mathrm{M})$ at $240 \mathrm{mbsf}$ and then increase one more time toward the bottom of the hole. The sharp downhole increase near the top of the hole occurs near the boundary between lithostratigraphic Units I and II (35 mbsf; see "Lithostratigraphy"), where physical properties profiles also show step changes. Unit I is an $\sim 34 \mathrm{~m}$ thick succession of Pleistocene sediment with alternating reddish brown clay, gray to dark brown foraminiferal ooze, grayish brown foraminiferal sand, and occasional sand- to pebble-sized lithics. Unit II is an $\sim 30 \mathrm{~m}$ thick succession of clay-rich sediment of early Miocene to Oligocene age. The boron increase at the bottom of the hole corresponds to Subunit IVb, consisting of (pinkish) white nannofossil chalk of Eocene age containing several chert beds.

Boron has been demonstrated in laboratory experiments and from field studies to be leached from terrigenous sediments into fluids (e.g., James et al., 2003; Deyhle and Kopf, 2002). The boron profile at Site U1410 suggests that the boron supply varied significantly in the different lithostratigraphic units.

\section{Sediment samples}

Sediment plugs $\left(5 \mathrm{~cm}^{3}\right)$ for downhole analysis of sediment elemental geochemistry were taken from Cores 342-U1410A-1H through $24 \mathrm{X}$ at an average resolution of one sample per section, adjacent to the moisture and density samples (Table T20).

\section{Results}

Concentrations of inorganic carbon vary from 0.04 to $12.4 \mathrm{wt} \%$ in Holes U1410A-U1410C (Table T20; Fig. F25). These concentrations are equivalent to 0.7-93 wt $\% \mathrm{CaCO}_{3}$, assuming that all of the carbonate is calcite.

Carbonate concentrations are $5-50 \mathrm{wt} \%$ in Pleistocene nannofossil ooze of lithostratigraphic Unit I 
and decrease to $0-20 \mathrm{wt} \%$ in upper Miocene to Oligocene clay of Unit II, which is consistent with low carbonate levels observed in other Oligocene-age sequences recovered during Expedition 342. In the expanded middle Eocene sequence represented by Unit III (see "Lithostratigraphy"), the alternating clayrich bedding and white nannofossil ooze layers have fluctuating carbonate values of 30-85 wt\%, with a few peaks of $\sim 85 \mathrm{wt} \%$ carbonate. The clay and ooze layers are further differentiated by physical properties including color reflectance $\left(\mathrm{L}^{*}\right)$, magnetic susceptibility, and NGR. Carbonate content increases to $90 \mathrm{wt} \%$ in Unit IV, which corresponds to early Eocene-age sediment.

Total organic carbon (TOC) values are typically $0.1-$ $0.3 \mathrm{wt} \%$ throughout the sediment column. TOC values, together with total nitrogen values, appear to decrease downhole from lithostratigraphic Unit III to IV. Organic matter is thermally immature and relatively well preserved with low $T_{\max }$ values $\left(380^{\circ}-\right.$ $420^{\circ} \mathrm{C}$ ). Organic matter is a mixture of Type II (algal and microbial) and Type III (land plant) kerogen.

\section{Discussion}

Based on shipboard age models, the low-carbonate interval (80-83 mbsf) immediately above Chron C19n corresponds to the MECO, which is widely regarded as the terminal Eocene hyperthermal event (e.g., Bohaty et al., 2009), marked by high temperatures and deep sea carbonate dissolution.

The striking intervals of rhythmic greenish gray nannofossil clay and white nannofossil ooze of middle Eocene age were also recovered at Southeast Newfoundland Ridge Sites U1407 (lithostratigraphic Unit III), U1408 (Unit III), and U1409 (Unit III). A similar succession, although diminished in its visual appearance, was also recovered in Oligocene-Miocene sediment at J-Anomaly Ridge sites (e.g., Site U1405).

As with other sites drilled to date on the Southeast Newfoundland Ridge (Sites U1407-U1410), the most prominent change in Hole U1410A is a step increase (from 50 to $90 \mathrm{wt} \% \mathrm{CaCO}_{3} ; \sim 100 \mathrm{mbsf}$ ) in sediment during nannofossil Zone NP14 (around the early/ middle Eocene boundary). This step correlates with shifts in several proxies (e.g., color reflectance, magnetic susceptibility, NGR, TOC, and total nitrogen values) and marks a transition from pelagic chalk sedimentation to clay deposition in the initial stages of sediment drift development.

\section{Physical properties}

We made physical properties measurements on whole-round sections, section halves, and discrete samples from section halves. Gamma ray attenuation (GRA) bulk density, magnetic susceptibility, $P$ wave velocity, and NGR measurements were made on whole-round sections using the Whole-Round Multisensor Logger (WRMSL) and Natural Gamma Radiation Logger. Compressional wave velocity on section halves was also measured at a frequency of two in each section (at $\sim 50$ and $100 \mathrm{~cm}$ ) using a $P$ wave caliper (PWC). For moisture and density (MAD) analyses, one discrete sample was collected in each section (typically at $\sim 35 \mathrm{~cm}$ from the top of a section) from Hole U1410A. The Section Half Multisensor Logger (SHMSL) was used to measure spectral reflectance and magnetic susceptibility on archive section halves.

\section{Magnetic susceptibility}

Overall, magnetic susceptibility ranges from -2 to 291 IU (Fig. F26). In lithostratigraphic Unit I (0 to $\sim 35$ mbsf), magnetic susceptibility is high and variable (8-291 IU) and increases (from 30 to $120 \mathrm{IU}$ ) downhole. Magnetic susceptibility decreases sharply to $20 \mathrm{IU}$ at the Unit I/II boundary. In Unit II, magnetic susceptibility averages $30 \mathrm{IU}$, but is also characterized by many superimposed peaks that correlate among all three holes. A sharp decrease to $\sim 5 \mathrm{IU}$ is observed at the contact with underlying Unit III. Magnetic susceptibility values remain much more uniform (0-20 IU) throughout Unit III, but high-frequency variations are observed between $\sim 70$ and 120 mbsf in all three holes. In Subunits IVa and IVb, magnetic susceptibility remains constant at $\sim 4$ and $13 \mathrm{IU}$, respectively.

\section{Density and porosity}

Two methods were used to measure bulk density at Site U1410. The GRA density method provides an estimate from whole-round sections, whereas the MAD method, applied to 183 discrete samples from Hole U1410A, provides a second, independent measure of bulk density, as well as dry bulk density, grain density, water content, and porosity.

At Site U1410, bulk density ranges from 1.5 to $2.4 \mathrm{~g} / \mathrm{cm}^{3}$ and gradually increases downhole. The downhole profile of MAD bulk density is consistent with that of GRA bulk density; however, MAD bulk density is on average $\sim 2 \%$ lower than GRA density in the APCcored section (Fig. F26). In lithostratigraphic Unit I, density varies from 1.6 to $1.8 \mathrm{~g} / \mathrm{cm}^{3}$ and decreases to $1.5 \mathrm{~g} / \mathrm{cm}^{3}$ at the Unit I/II boundary (35 mbsf). Bulk density increases downhole from 1.5 to $1.9 \mathrm{~g} / \mathrm{cm}^{3}$ in Units II and III. Two superimposed peaks that correlate among all three holes occur within this interval, at $\sim 50$ and 160 mbsf. Bulk density values fluctuate 
between 1.8 and $2.1 \mathrm{~g} / \mathrm{cm}^{3}$ in Unit IV, and increase to $\sim 2.0 \mathrm{~g} / \mathrm{cm}^{3}$ at the bottom of Subunit IVb.

Water content in sediment from Hole U1410A ranges from 21 to $53 \mathrm{wt} \%$, and porosity varies from 43 to 76 vol\%. Generally, water content and porosity decrease downhole; this trend is expected because of sediment compaction. In Unit I, both properties display high values $(30-48 \mathrm{wt} \%$ for water content and 55-70 vol\% for porosity). In Unit II, water content and porosity fluctuate from 41 to $53 \mathrm{wt} \%$ and from 65 to $76 \mathrm{vol} \%$, respectively. These physical properties gradually decrease downhole in Unit III (from 37 to $26 \mathrm{wt} \%$ for water content and 61 to $50 \mathrm{vol} \%$ for porosity). In Subunits IVa and IVb, water content and porosity fluctuate from 23 to $35 \mathrm{wt} \%$ and from 44 to 59 vol\%, respectively.

Grain density ranges from 2.6 to $3.3 \mathrm{~g} / \mathrm{cm}^{3}$ in Hole U1410A. From the top of the hole to $\sim 20 \mathrm{mbsf}$, grain density values are high $\left(>2.8 \mathrm{~g} / \mathrm{cm}^{3}\right)$, whereas below this interval, grain density values remain uniform and average $\sim 2.75 \mathrm{~g} / \mathrm{cm}^{3}$. High values may be the result of high manganese oxide content in the sediment. Alternatively, the high values may be an artifact of measuring sandy (foraminiferal) and silty clay that may not be completely saturated.

\section{P-wave velocity}

$P$-wave velocity was measured using the PWL on all whole-round sections and using the PWC on undisturbed section halves from Holes U1410A-U1410C.

$P$-wave velocity ranges from 1500 to $1650 \mathrm{~m} / \mathrm{s}$ in PWL data and from 1490 to $1960 \mathrm{~m} / \mathrm{s}$ in PWC data in all three holes. PWC values are consistently lower than the PWL values by $\sim 20 \mathrm{~m} / \mathrm{s}$ in the APC-cored section (Fig. F27). $P$-wave velocity gradually increases downhole and maximum velocities are recorded at the bottom of the hole. PWL measurements were not performed in the lower part of lithostratigraphic Unit III and Subunits IVb and IVc in Holes U1410A and U1410C (from 160 mbsf to the bottom of each hole). PWC measurements show higher variations within this interval; we attribute this variability to the change in coring methods from APC to XCB.

\section{Natural gamma radiation}

NGR was measured on whole-round sections from Holes U1410A-U1410C. Overall, values range from 2 to 47 cps. Through lithostratigraphic Unit I, NGR increases downhole from 13 to 42 cps (Fig. F27), a trend that is in step with a decrease in carbonate content (see "Geochemistry"). In Unit II, NGR decreases to a minimum of $<20$ cps at $\sim 48$ mbsf in Hole
U1410A, 50 mbsf in Hole U1410B, and 45 mbsf in Hole U1410C. NGR values increase to $40 \mathrm{cps}$ downhole through the rest of Unit II but abruptly decrease to $30 \mathrm{cps}$ at the Unit II/III boundary. Carbonate content increases abruptly across the Unit II/III boundary. In Unit III, NGR values remain relatively constant and fluctuate between 13 and 30 cps. Three shifts at $\sim 82,110$, and 160 mbsf can be correlated among all three holes. All of these peaks correspond to alternations between greenish clay and whitish carbonate-rich clay layers (see "Lithostratigraphy"). The shift observed at 160 mbsf coincides with a slight increase in carbonate content. NGR values rapidly decrease from 27 to $10 \mathrm{cps}$ at the Unit III/IV boundary at 215 mbsf; this shift corresponds to the transition from gray-green carbonate-poor sediment of Unit III to carbonate-rich white chalk of Unit IV. In the carbonate-rich Subunits IVa and IVb, NGR remains uniformly low ( 10 cps).

\section{Color reflectance}

Color reflectance was measured on archive section halves from all three holes. The standard operating resolution of data acquisition was decreased from 2.5 to $5 \mathrm{~cm}$ in all three holes because the rate of core recovery required faster processing. Changes in color reflectance parameters $\mathrm{a}^{*}$ and $\mathrm{b}^{*}$ are consistent among all three holes (Fig. F28). In lithostratigraphic Unit I, values average $\sim 1$ for $\mathrm{a}^{*}$ and $\sim 0$ for $\mathrm{b}^{*}$. In Unit II, $\mathrm{a}^{*}$ and $\mathrm{b}^{*}$ values show more variations $\left(\mathrm{a}^{*}\right.$ and $\mathrm{b}^{*}$ range from -4 to 8.5 and from -5.5 to 16 , respectively); this variability is associated with the large changes in sediment color (from light olive-gray to dark greenish gray) of this unit (see "Lithostratigraphy"). Through Unit III, $\mathrm{a}^{*}$ and $\mathrm{b}^{*}$ remain relatively constant, and $\mathrm{a}^{*}$ averages 0 whereas $\mathrm{b}^{*}$ averages -1 . From the Unit III/IV boundary ( $210 \mathrm{mbsf})$ to the base of Subunit IVb, $\mathrm{a}^{*}$ and $\mathrm{b}^{*}$ increase from -2 to 12 and from -3 to 8 , respectively. The increase in $\mathrm{a}^{*}$ and $\mathrm{b}^{*}$ corresponds to the change from greenish to pinkish white sediment. In Subunit IVb, $a^{*}$ and $b^{*}$ remain constant, with $\mathrm{a}^{*}$ ranging from 4 to 8 and $\mathrm{b}^{*}$ ranging from 5 to 10 ).

$\mathrm{L}^{*}$ exhibits the same downhole trend in all three holes. From the top of the hole to $\sim 40 \mathrm{mbsf}$, $\mathrm{L}^{*}$ decreases downhole from $\sim 55$ to 40 . A shift to higher values, with a peak of 60 , occurs at $\sim 42$ mbsf. Below this level, $L^{*}$ values continue to increase slightly (from 50 to 65) to the bottom of Unit III. Two broad peaks occur at $\sim 115$ and $\sim 150$ mbsf within this interval. At the contact with the underlying Subunit IVa (at $215 \mathrm{mbsf}$ ), $\mathrm{L}^{*}$ values increase sharply from 65 to 90 , a shift that correlates with the transition from gray-green nannofossil clay to white nannofossil chalk. $L^{*}$ values remain high and constant, with an 
average value of 85 , throughout Subunits IVa and $\mathrm{IVb}$. The major variations in $\mathrm{L}^{*}$ recorded at Site U1410 occur at the same levels as changes in the NGR data series (Fig. F28). This pattern correlates to changes in calcium carbonate content (see "Geochemistry").

\section{Thermal conductivity}

Twenty-eight measurements were completed on whole-round sections from Hole U1410A (Table T21). Overall, thermal conductivity ranges from 0.9 to 1.5 $\mathrm{W} /(\mathrm{m} \cdot \mathrm{K})$ (Fig. F29). In lithostratigraphic Unit I, thermal conductivity ranges from 0.9 to $1.4 \mathrm{~W} /(\mathrm{m} \cdot \mathrm{K})$. From the top of Unit II to the bottom of the hole, thermal conductivity values increase gradually downhole from $\sim 1.1$ to $1.5 \mathrm{~W} /(\mathrm{m} \cdot \mathrm{K})$. Thermal conductivity measurements approximately correlate to GRA bulk density values $\left(R^{2}=\sim 0.58\right)$ (Fig. F30).

\section{Stratigraphic correlation}

\section{Sampling splice}

We constructed a sampling splice for Site U1410 that is continuous to $\sim 226 \mathrm{~m}$ core composite depth below seafloor (CCSF) based on unambiguous signals in magnetic susceptibility. Physical property data at Site U1410 are very similar to those from Site U1408-orbital cyclicity superimposed on clear long-term trends provided useful patterns to correlate among the three holes. Clear trends and patterns in NGR also aided verification of the splice (Fig. F31). Hole U1410A is the deepest hole drilled at this site, with a maximum depth of $\sim 260$ mbsf ( $280 \mathrm{~m}$ CCSF). Holes $\mathrm{U} 1410 \mathrm{~B}$ and U1410C extended to $245.2 \mathrm{~m}$ mbsf (265.37 $\mathrm{m} \mathrm{CCSF}$ ) and $243.8 \mathrm{~m}$ mbsf $(258.51 \mathrm{~m}$ CCSF), respectively. We are most confident about the correlation among the three holes for the upper $\sim 170 \mathrm{~m}$ CCSF. Below this depth, some tie points are more tentative because of ambiguous patterns in physical properties. Across the middle to early Eocene transition, a distinct lithostratigraphic change from green clay-rich sediments to white calcium carbonate-rich strata is accompanied by a sharp downhole decrease in magnetic susceptibility values to almost zero. As a result, correlations are tentative in the carbonate-rich interval. These tentative tie points are denoted in the offset and tie point tables (Tables T22, T23). Additional shore-based data will be used to verify the accuracy of the splice in this interval. Our correlation results in a growth rate of $6 \%$ for Holes U1410A-U1410C (Fig. F32).

\section{Correlation during drilling operations}

Based on correlation between WRMSL magnetic susceptibility data generated on cores from Hole U1410A and STMSL magnetic susceptibility data generated on cores from Holes U1410B and U1410C, we were able to guide drilling operations. Good estimates of seafloor depth enabled drilling operations to achieve the targeted lengths of mudline cores in Holes U1410B and U1410C, which were 3.8 and $6.8 \mathrm{~m}$, respectively. Below the relatively thick $(\sim 35 \mathrm{~m})$ Pleistocene-Pliocene cover, magnetic susceptibility values dropped; however, the signal was sufficient to guide drilling. Orbital cycles in both the Pleistocene and Eocene intervals yielded good depth control. Offsets among cores from adjacent holes decreased incrementally with depth because of varying resistance of the lithology while drilling. However, we were able to secure a continuous splice downhole to 226 m CCSF, with only a few depth adjustments made while drilling in Holes U1410B and U1410C.

\section{Correlation and splice construction}

Orbital cyclicity in the WRMSL magnetic susceptibility data, in combination with similar, but lower resolution patterns and trends in NGR (see "Physical properties") (Fig. F31) formed the primary signal for constructing the composite depth scale and splice. Core $342-\mathrm{U} 1410 \mathrm{~A}-1 \mathrm{H}$ is defined as the anchor in the splice because it is the longest of the three mudline cores recovered. The clear cyclicity present in the uppermost, relatively thick (compared to other sites at J-Anomaly Ridge and South East Newfoundland Ridge) Pleistocene-Pliocene cover disappears in the very condensed Pliocene to late Eocene interval between $\sim 35$ and $\sim 65 \mathrm{~m}$ CCSF. Throughout the Eocene drift deposit, between $\sim 65$ and $\sim 228 \mathrm{~m} \mathrm{CCSF}$ and corresponding to lithostratigraphic Unit III (see "Lithostratigraphy"), persistent orbital cyclicity is again present. Cycle amplitude is largest in the upper part of the sequence and drops to lower amplitudes below $145 \mathrm{~m}$ CCSF. Tie points in the lower portion of the record are therefore more tentative and require shore-based verification.

At $\sim 228 \mathrm{~m} \mathrm{CCSF}$, the transition from the middle to early Eocene is marked by different lithologies recovered in Hole U1410A with respect to Holes U1410B and U1410C. In Hole U1410A, a gradual transition in magnetic susceptibility and NGR values correspond to clear cycles in the lithology from greenish clay to white carbonate, whereas in Holes U1410B and U1410C, these cycles are absent. We interpret a gap in Hole U1410A and append Core 342-U1410A- 
23X to the bottom of Core 342-U1410C-23X. Below, we interpret gaps between Cores 342-U1410B-25X and 26X and between Cores 342-U1410C-23X and $24 X$. No operational explanation is apparent for such gaps; rather, we consider the gaps in the composite depth scale reflective of lateral variability within the formation at the middle to early Eocene transition. Relatively strong APC coring disturbance, with variable expansion-compression profiles along the lengths of the cores, is recognizable in cores across all three holes at Site U1410. Cores 342U1410A-27X and 28X were appended because this interval was not recovered in Holes U1410B and U1410C.

\section{References}

Bohaty, S.M., Zachos, J.C., Florindo, F., and Delaney, M.L., 2009. Coupled greenhouse warming and deep-sea acidification in the middle Eocene. Paleoceanography, 24(2):PA2207. doi:10.1029/2008PA001676

Deyhle, A., and Kopf, A., 2002. Strong B enrichment and anomalous $\delta^{11} \mathrm{~B}$ in pore fluids from the Japan Trench forearc. Mar. Geol., 183(1-4):1-15. doi:10.1016/ S0025-3227(02)00186-X

Norris, R.D., Wilson, P.A., Blum, P., Fehr, A., Agnini, C., Bornemann, A., Boulila, S., Bown, P.R., Cournede, C., Friedrich, O., Ghosh, A.K., Hollis, C.J., Hull, P.M., Jo, K., Junium, C.K., Kaneko, M., Liebrand, D., Lippert, P.C., Liu, Z., Matsui, H., Moriya, K., Nishi, H., Opdyke, B.N., Penman, D., Romans, B., Scher, H.D., Sexton, P., Takagi, H., Turner, S.K., Whiteside, J.H., Yamaguchi, T., and Yamamoto, Y., 2014a. Methods. In Norris, R.D., Wilson, P.A., Blum, P., and the Expedition 342 Scientists, Proc. IODP, 342: College Station, TX (Integrated Ocean Drilling Program). doi:10.2204/iodp.proc.342.102.2014

Norris, R.D., Wilson, P.A., Blum, P., Fehr, A., Agnini, C., Bornemann, A., Boulila, S., Bown, P.R., Cournede, C., Friedrich, O., Ghosh, A.K., Hollis, C.J., Hull, P.M., Jo, K., Junium, C.K., Kaneko, M., Liebrand, D., Lippert, P.C., Liu, Z., Matsui, H., Moriya, K., Nishi, H., Opdyke, B.N., Penman, D., Romans, B., Scher, H.D., Sexton, P., Takagi, H., Turner, S.K., Whiteside, J.H., Yamaguchi, T., and Yamamoto, Y., 2014b. Site U1403. In Norris, R.D., Wilson, P.A., Blum, P., and the Expedition 342 Scientists, Proc. IODP, 342: College Station, TX (Integrated Ocean Drilling Program). doi:10.2204/ iodp.proc.342.104.2014

Norris, R.D., Wilson, P.A., Blum, P., Fehr, A., Agnini, C., Bornemann, A., Boulila, S., Bown, P.R., Cournede, C.,
Friedrich, O., Ghosh, A.K., Hollis, C.J., Hull, P.M., Jo, K., Junium, C.K., Kaneko, M., Liebrand, D., Lippert, P.C., Liu, Z., Matsui, H., Moriya, K., Nishi, H., Opdyke, B.N., Penman, D., Romans, B., Scher, H.D., Sexton, P., Takagi, H., Turner, S.K., Whiteside, J.H., Yamaguchi, T., and Yamamoto, Y., 2014c. Site U1404. In Norris, R.D., Wilson, P.A., Blum, P., and the Expedition 342 Scientists, Proc. IODP, 342: College Station, TX (Integrated Ocean Drilling Program). doi:10.2204/

iodp.proc.342.105.2014

Norris, R.D., Wilson, P.A., Blum, P., Fehr, A., Agnini, C., Bornemann, A., Boulila, S., Bown, P.R., Cournede, C., Friedrich, O., Ghosh, A.K., Hollis, C.J., Hull, P.M., Jo, K., Junium, C.K., Kaneko, M., Liebrand, D., Lippert, P.C., Liu, Z., Matsui, H., Moriya, K., Nishi, H., Opdyke, B.N., Penman, D., Romans, B., Scher, H.D., Sexton, P., Takagi, H., Turner, S.K., Whiteside, J.H., Yamaguchi, T., and Yamamoto, Y., 2014d. Site U1409. In Norris, R.D., Wilson, P.A., Blum, P., and the Expedition 342 Scientists, Proc. IODP, 342: College Station, TX (Integrated Ocean Drilling Program). doi:10.2204/ iodp.proc.342.110.2014

Gieskes, J.M., and Lawrence, J.R., 1981. Alteration of volcanic matter in deep-sea sediments: evidence from the chemical composition of interstitial waters from deep sea drilling cores. Geochim. Cosmochim. Acta, 45(10):1687-1703. doi:10.1016/ 0016-7037(81)90004-1

Gradstein, F.M., Ogg, J.G., Schmitz, M.D., and Ogg, G.M. (Eds)., 2012. The Geological Time Scale 2012: Amsterdam (Elsevier).

James, R.H., Allen, D.E., and Seyfried, W.E., Jr., 2003. An experimental study of alteration of oceanic crust and terrigenous sediments at moderate temperatures (51 to $350^{\circ} \mathrm{C}$ ): insights as to chemical processes in near-shore ridge-flank hydrothermal systems. Geochim. Cosmochim. Acta, 67(4):681-691. doi:10.1016/S00167037(02)01113-4

Kirschvink, J.L., 1980. The least-squares line and plane and the analysis of palaeomagnetic data. Geophys. J. $R$. Astron. Soc., 62(3):699-718. doi:10.1111/j.1365246X.1980.tb02601.x

Tucholke, B.E., and Vogt, P.R., 1979. Western North Atlantic: sedimentary evolution and aspects of tectonic history. In Tucholke, B.E., Vogt, P.R., et al., Init. Repts. DSDP, 43: Washington, DC (U.S. Govt. Printing Office), 791825. doi:10.2973/dsdp.proc.43.140.1979

Publication: 3 March 2014 MS 342-111 
Figure F1. Bathymetric map for northwestern Southeast Newfoundland Ridge, northeast of J-Anomaly Ridge. Data are based upon multibeam mapping by KNR179-1 site survey. Single-channel seismic reflection profiles are shown in Figures F2 and F3.

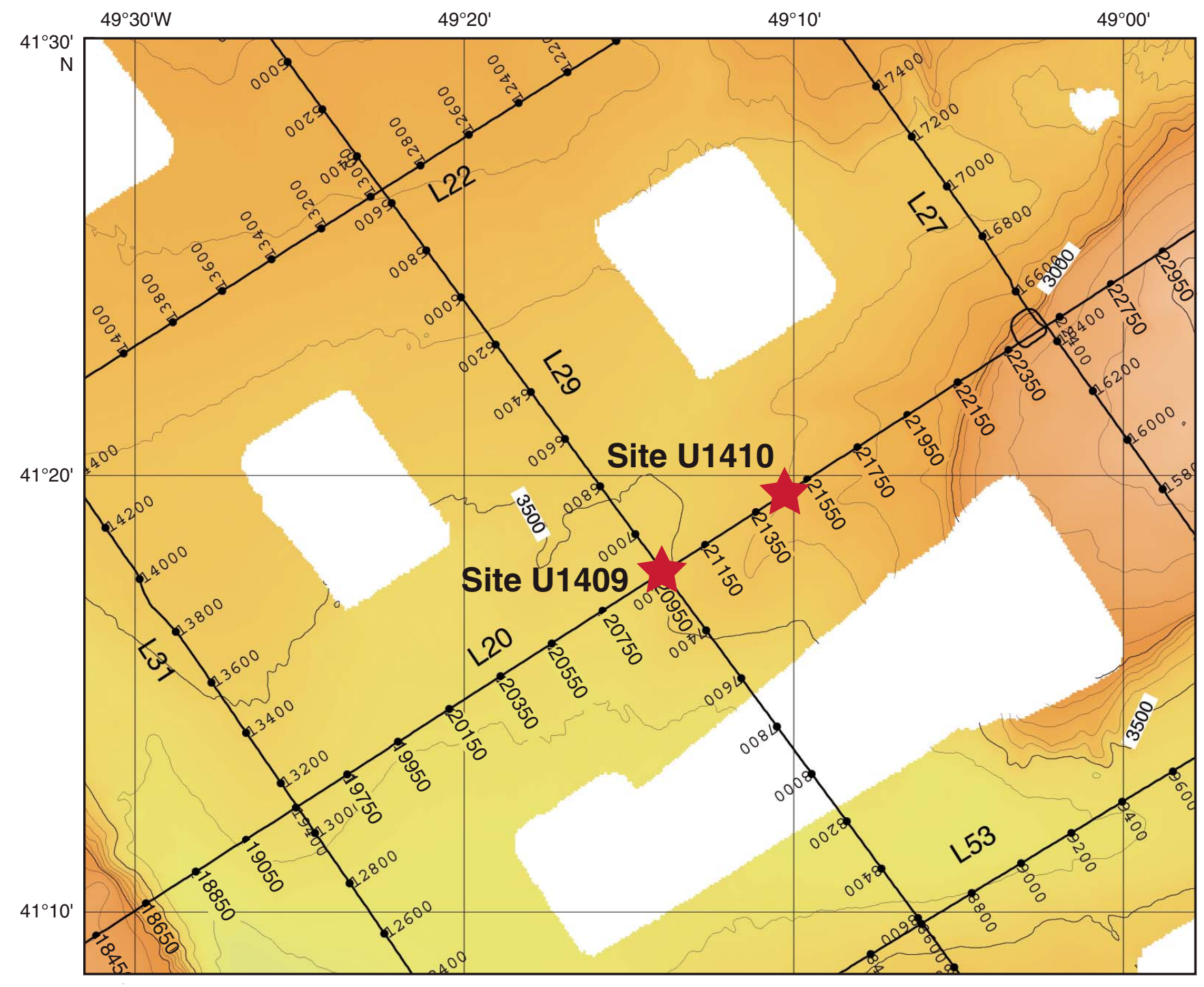


Figure F2. Single-channel seismic KNR179-1 Line 20. This is the southwest-northeast line crossing Site U1410 (at shotpoint [SP] 21480). White boxes represent approximate depth of penetration at Sites U1409 and U1410.

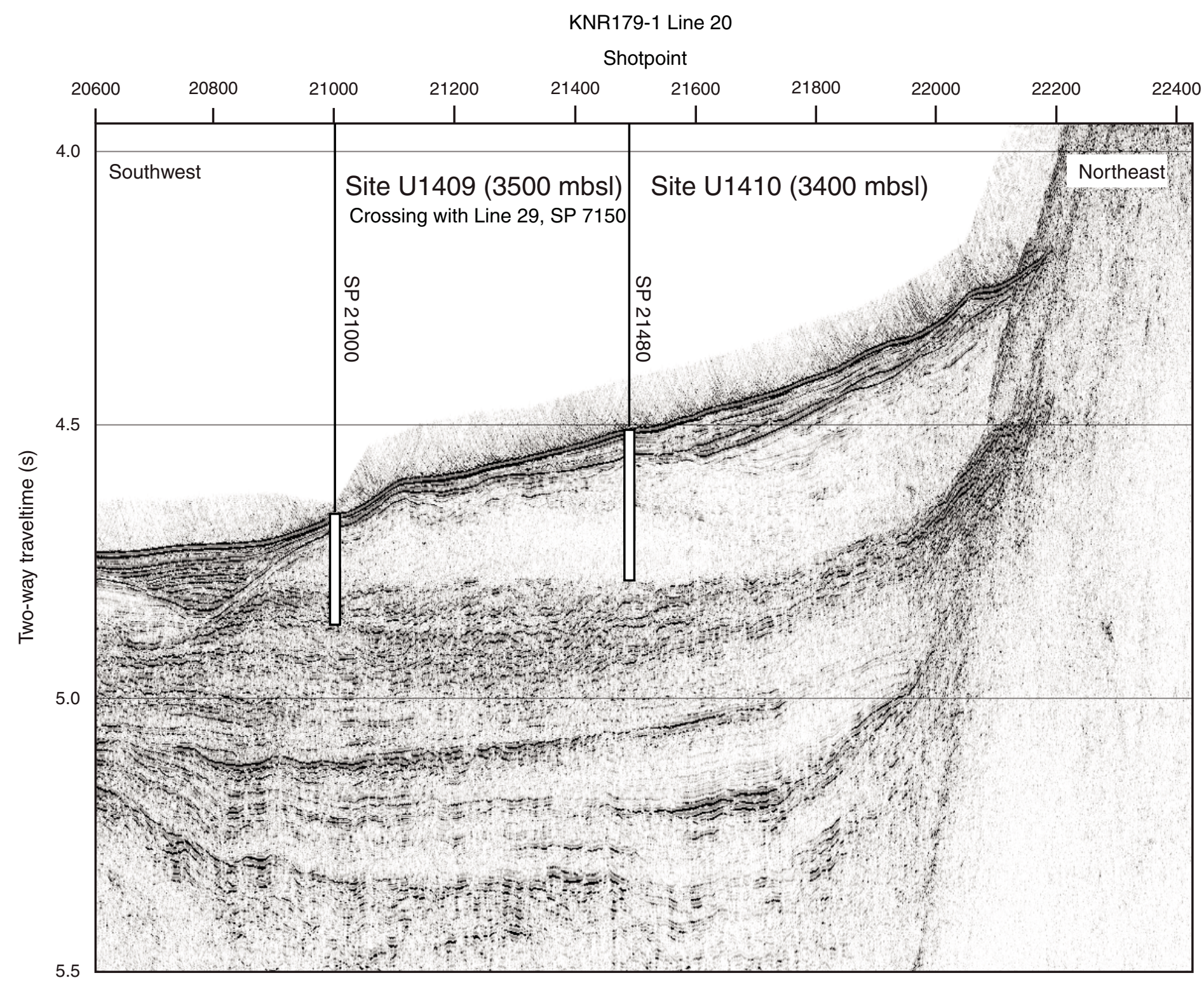


Figure F3. Single-channel seismic KNR179-1 Line 29. This is the northwest-southeast line passing southwest of Site U1410 (northeast of line crossing at shotpoint [SP] 21000). The record of the acoustically-transparent zone between $\sim 4.7-4.8 \mathrm{~s}$ two-way traveltime is thicker at Site U1410 than shown on KNR1970-1, Line 29, but the overall geometry of the sediment drift is similar.

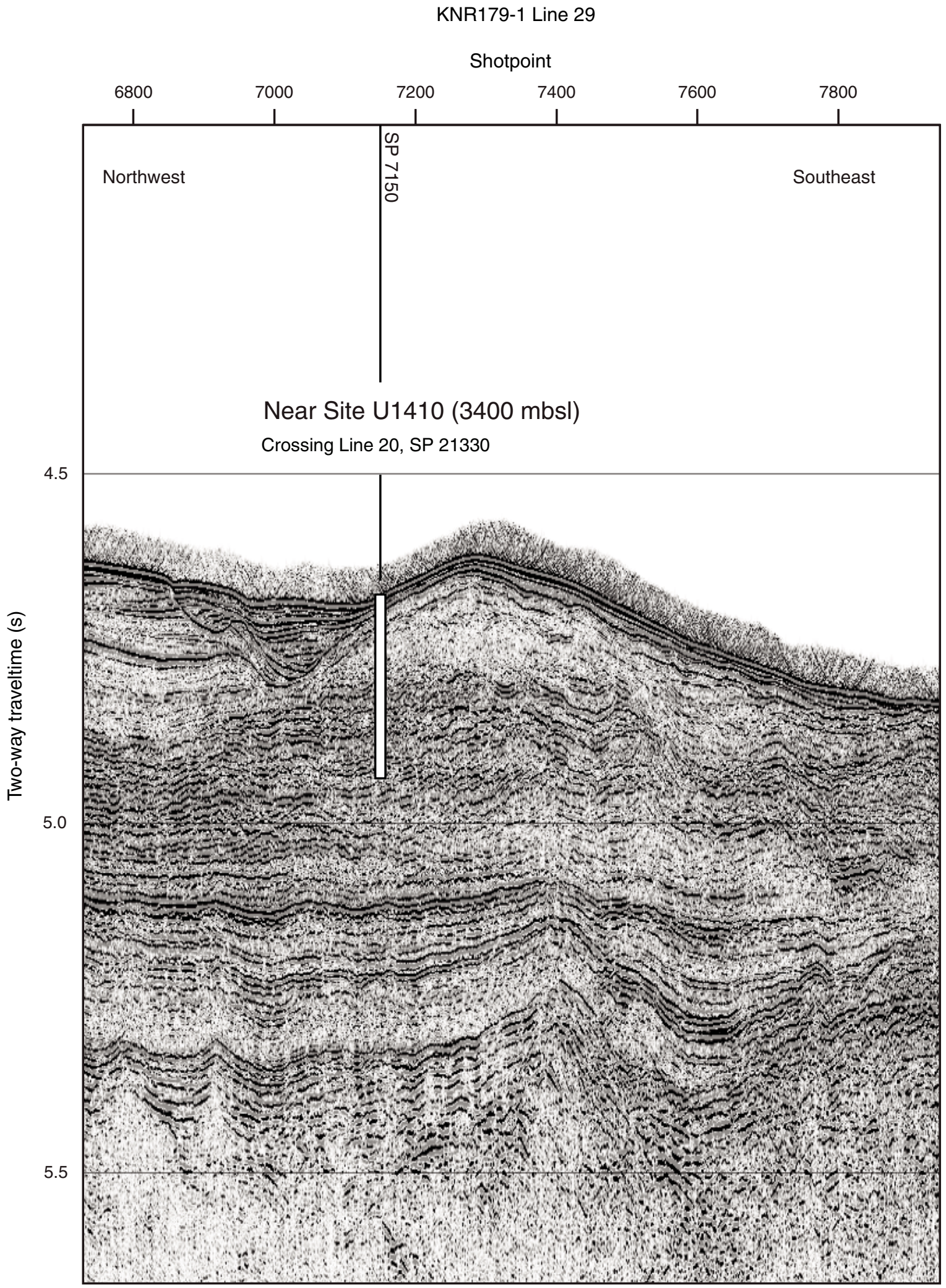


Figure F4. Lithostratigraphic summary, Site U1410. Typically the lighter colors reflect higher carbonate content. Note the green to pink/tan transition in the color data at the Unit III/IV boundary.

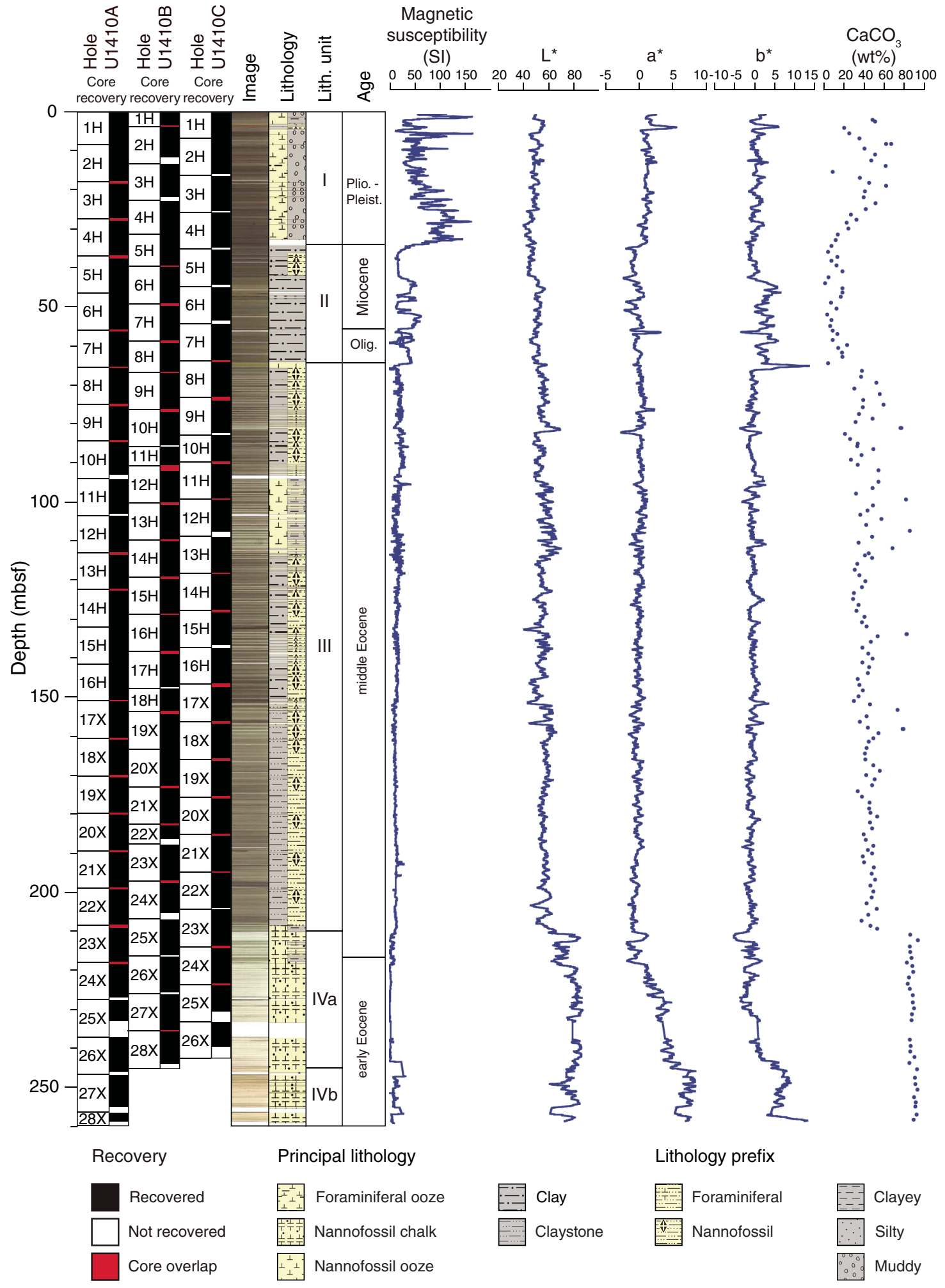


Figure F5. Core images from most common lithologies, Site U1410. A. Pleistocene silty clay, Unit I. B. Pleistocene muddy foraminiferal sand overlying reddish brown clay, Unit I. C. Miocene clay with nannofossils, Unit II. D. Oligocene clay with nannofossils, Unit II. E. Middle Eocene light gray nannofossil ooze (top) alternating with greenish gray nannofossil clay (bottom), Unit III. F. Early Eocene nannofossil chalk, Subunit IVa. G. Early Eocene chert (top) and nannofossil chalk (bottom), Subunit IVb.
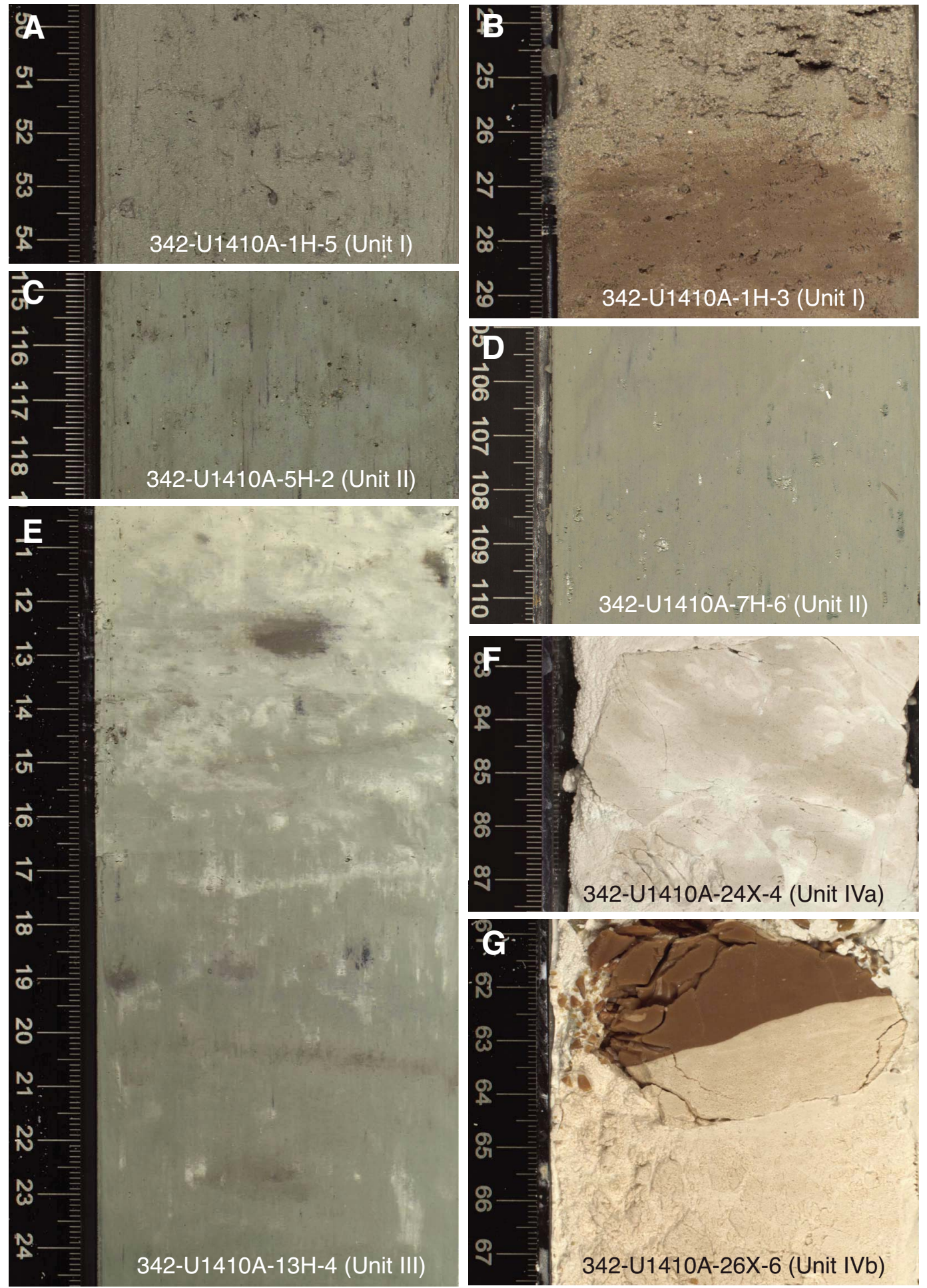
Figure F6. Photomicrographs of smear slides indicating the dominant lithologies of Units I-IV, Site U1410. A. Silty clay with nannofossils, Unit I. B. Clay with nannofossils, Unit II. C. Nannofossil ooze with foraminifers, Unit III. D. Nannofossil chalk with radiolarians, Unit IV.
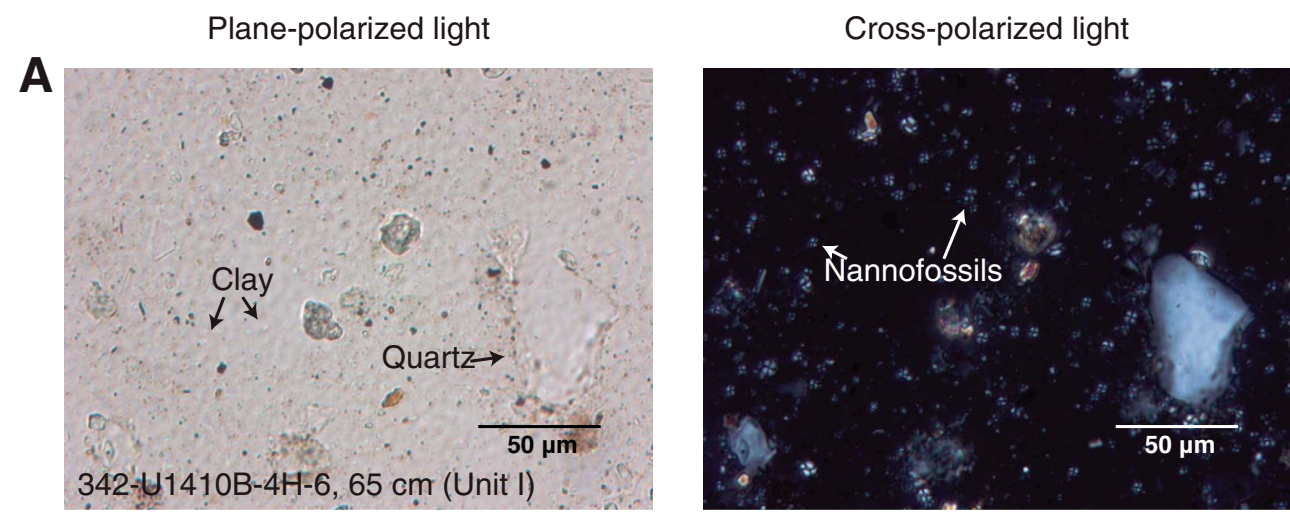

B
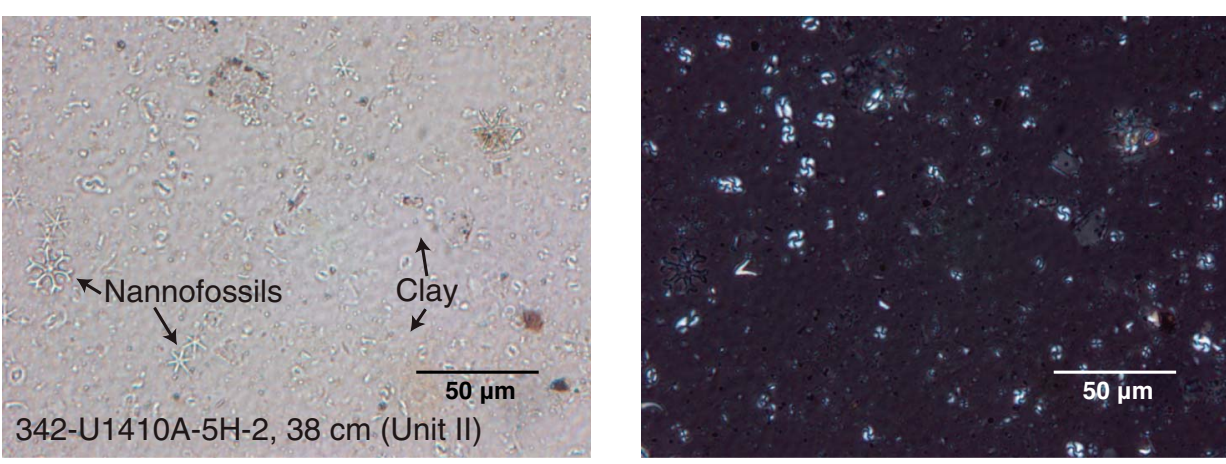

C
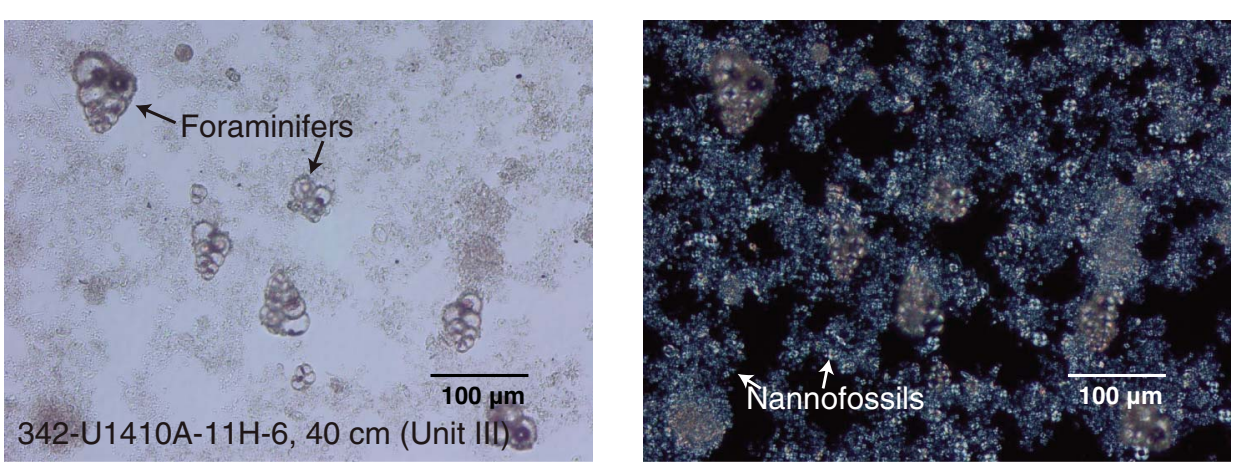

D
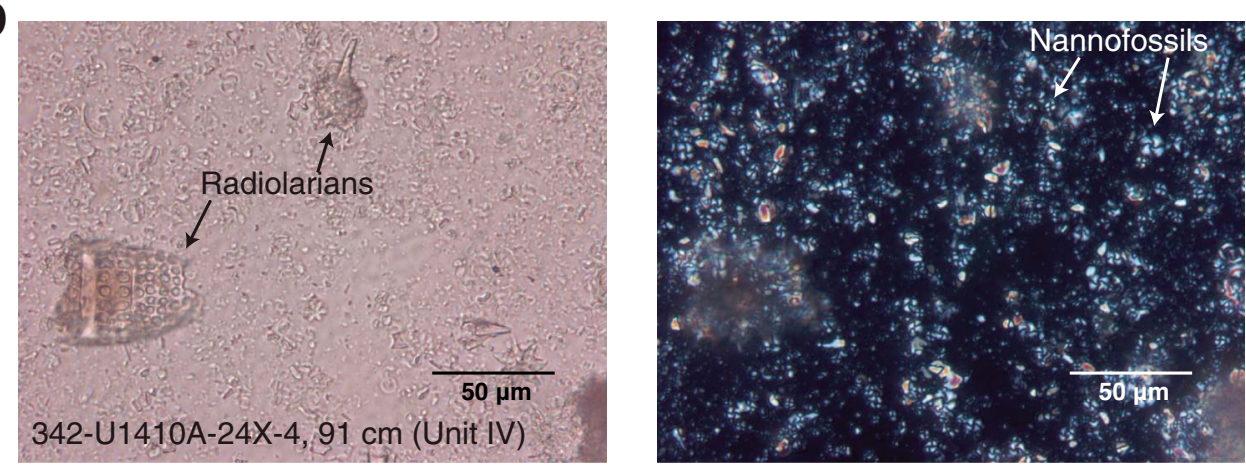
Figure F7. Plots of smear slide results of major biogenic and lithologic components and their relative abundance, Hole U1410A. VA = very abundant, $\mathrm{A}=$ abundant, $\mathrm{C}=$ common, $\mathrm{F}=$ few, $\mathrm{P}=$ present.

Hole U1410A

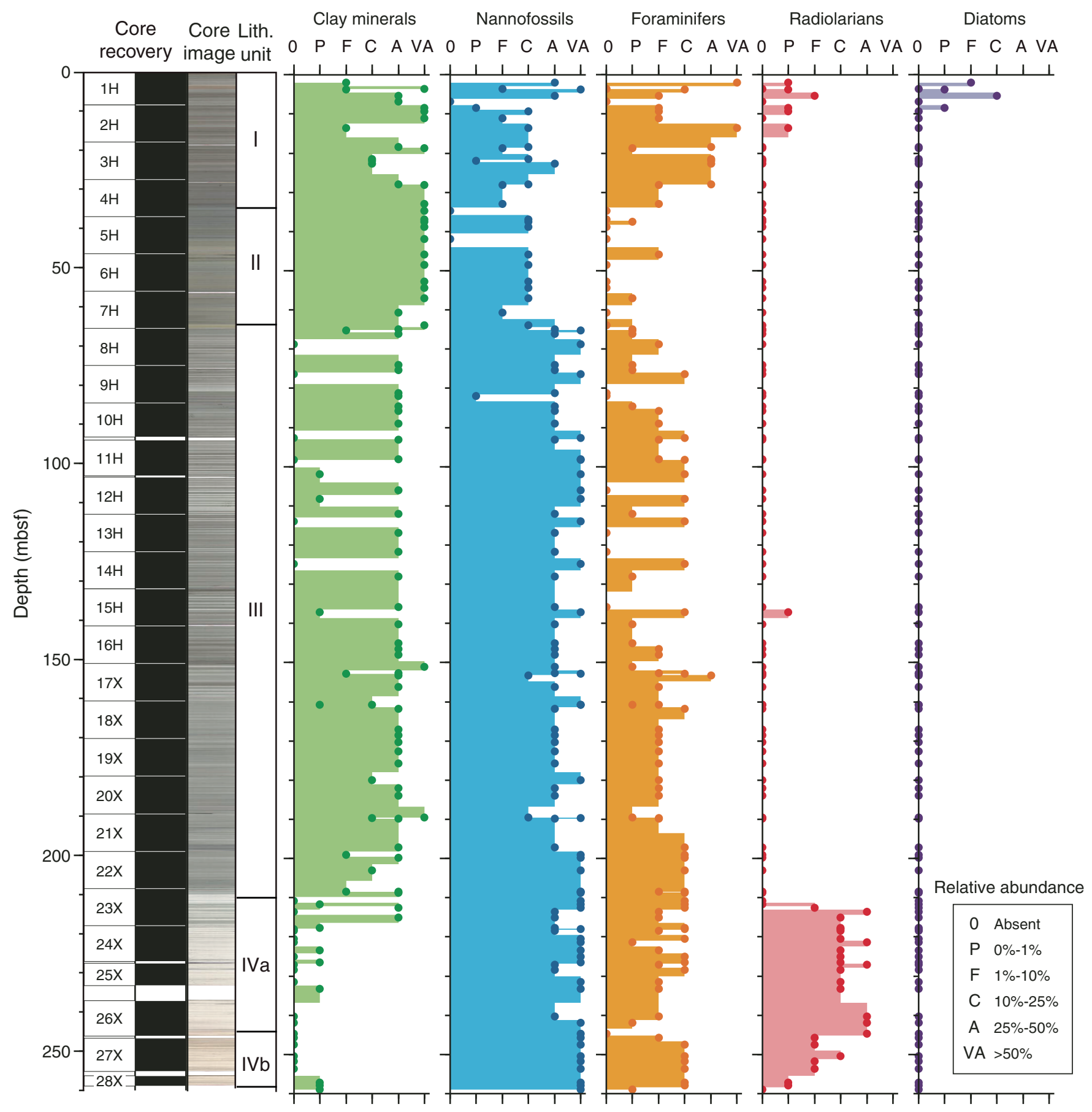


Figure F8. Plots of smear slide results of major biogenic and lithological components and their relative abundance, Hole U1410B. VA = very abundant, $\mathrm{A}=$ abundant, $\mathrm{C}=$ common, $\mathrm{F}=$ few, $\mathrm{P}=$ present.

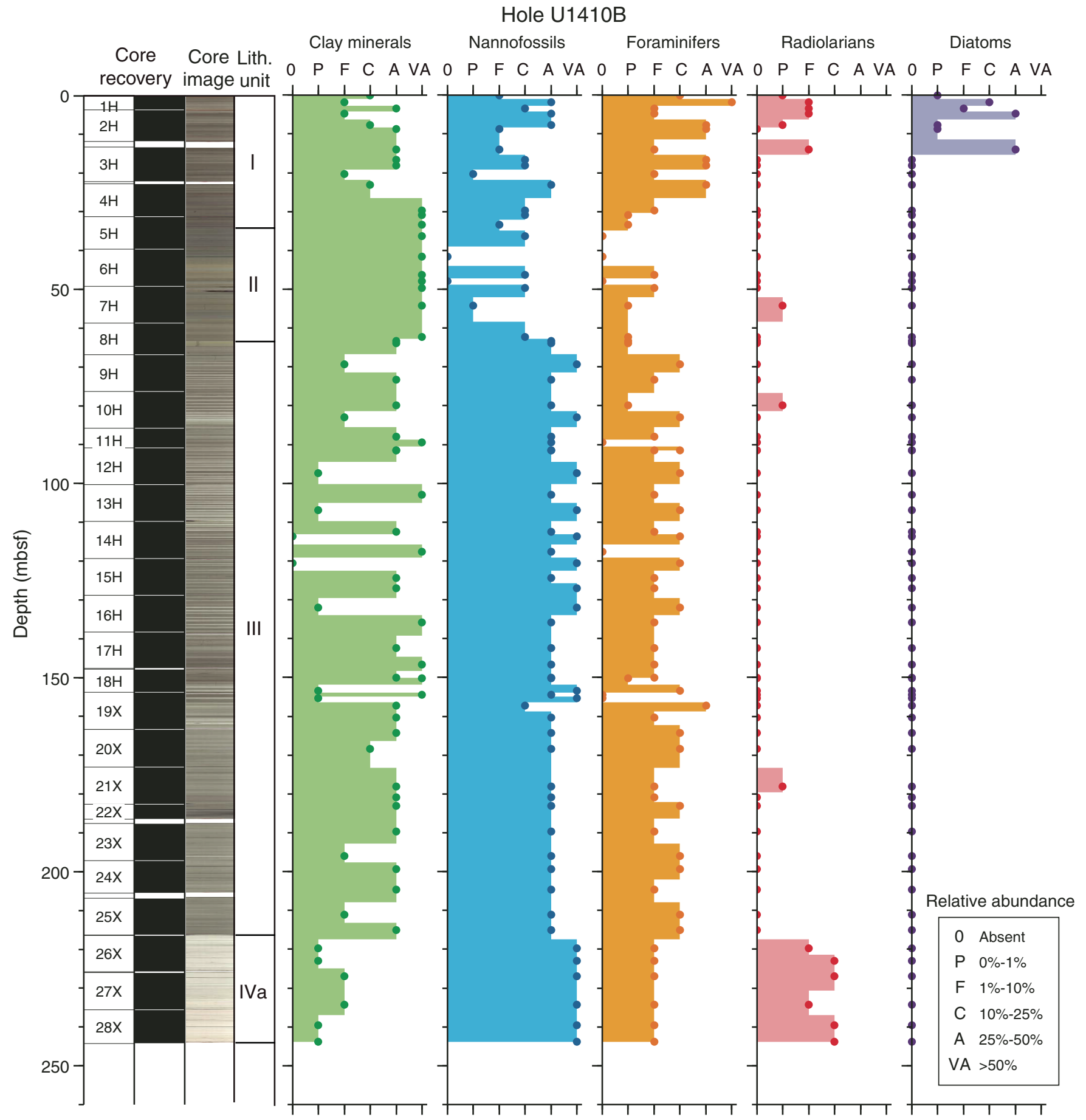


Figure F9. Plots of smear slide results of major biogenic and lithological components and their relative abundance, Hole U1410C. VA = very abundant, $\mathrm{A}=$ abundant, $\mathrm{C}=$ common, $\mathrm{F}=\mathrm{few}, \mathrm{P}=$ present.

Hole U1410C

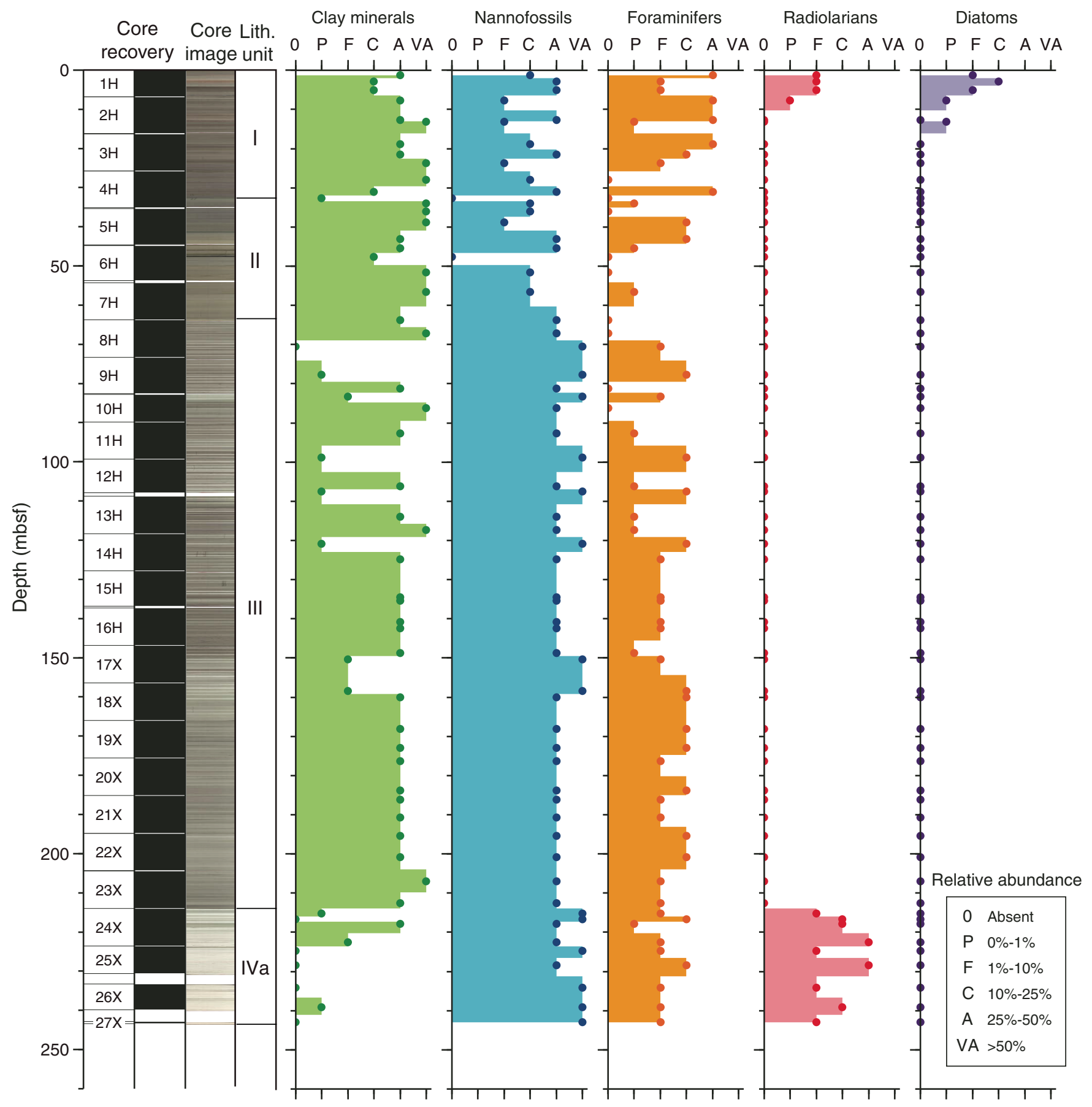


Figure F10. Core images of Miocene-Oligocene greenish gray nannofossil clay of Unit II showing dispersed quartz in (A) millimeter-scale patches/blebs and, more rarely, (B) a discontinuous lens, Site U1410. C. Mineralogy based on X-ray diffractometry of a sample of silt- to fine sand-sized white material. The clay and calcite peaks are from the background lithology within which the quartz occurs. D. Photomicrograph of smear slide showing angular quartz in coarse silt to very fine sand size range.

A

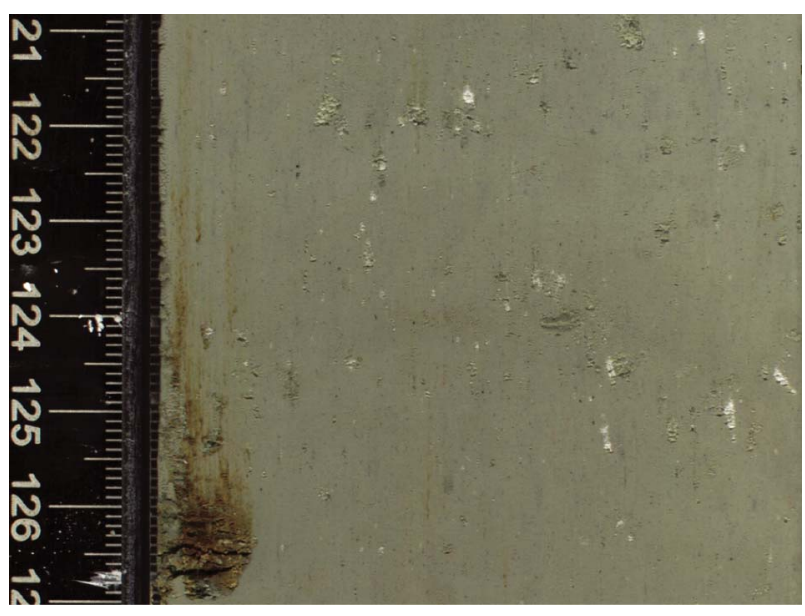

342-U1410B-7H-2

C

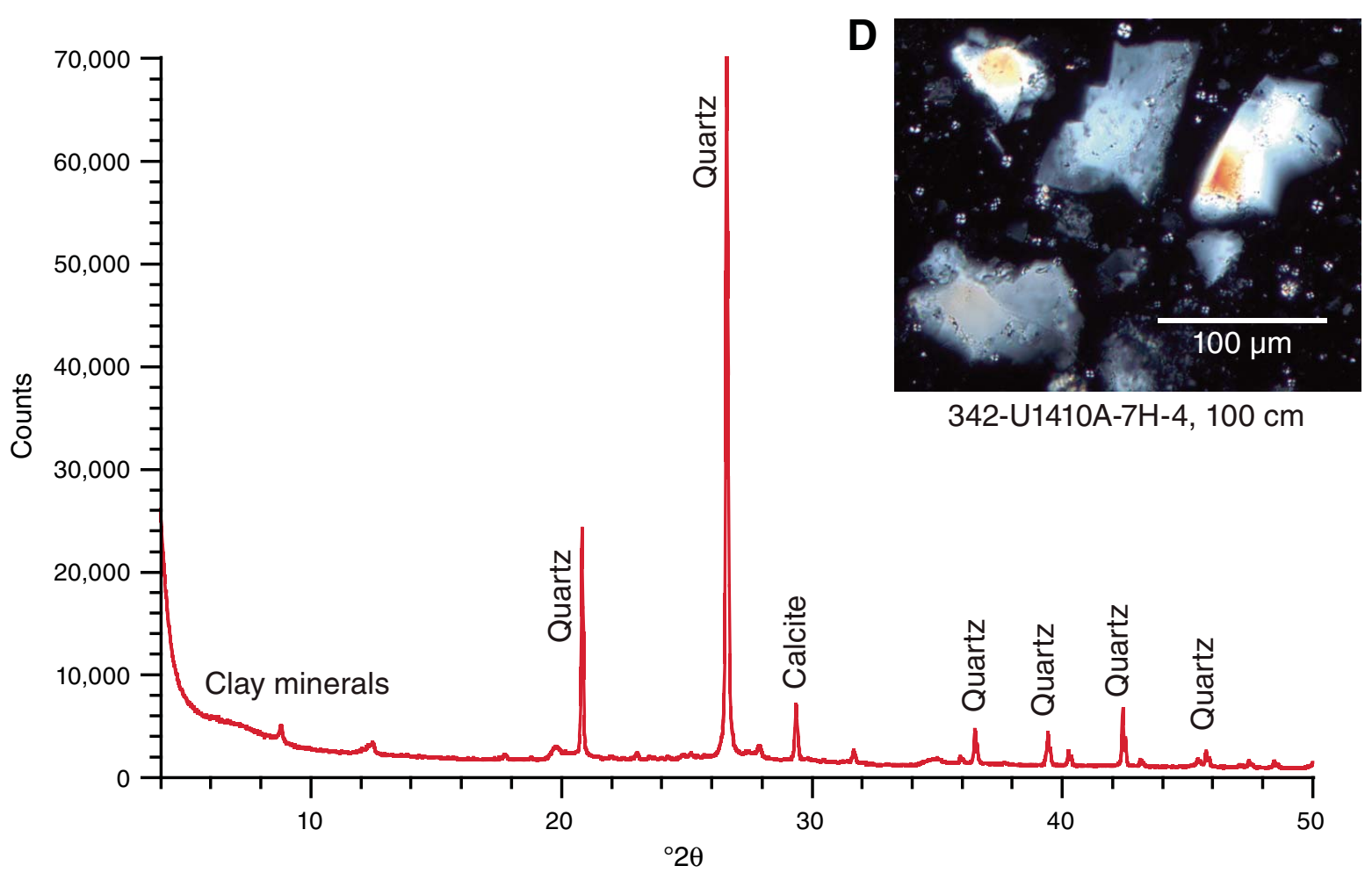

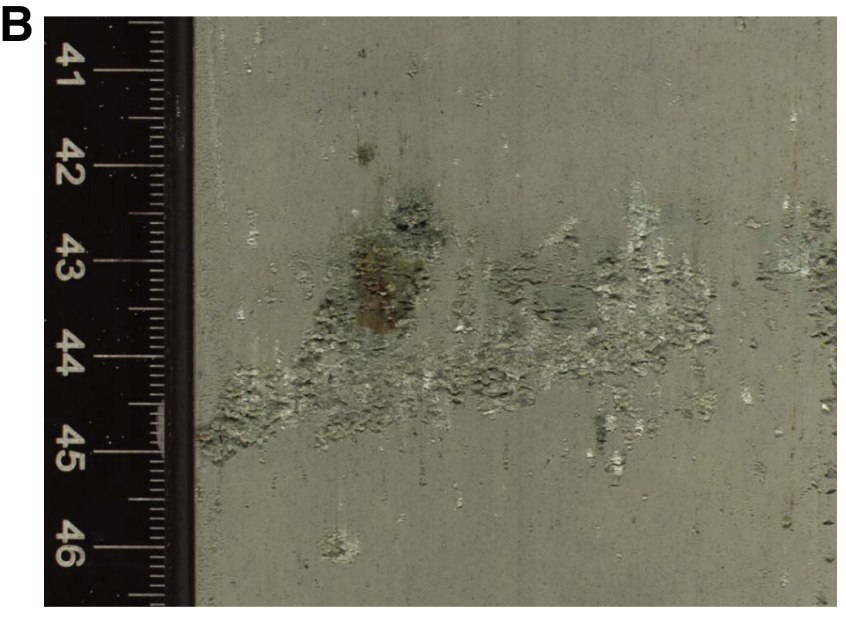

342-U1410C-6H-4 
Figure F11. Core image and physical property data showing middle Eocene cyclicity in lithology, magnetic susceptibility, color reflectance $\left(\mathrm{L}^{*}\right)$ and natural gamma radiation (NGR), Core 342-U1410A-12H. All show wellexpressed cyclicity over this interval (nannofossil Subzone NP16).

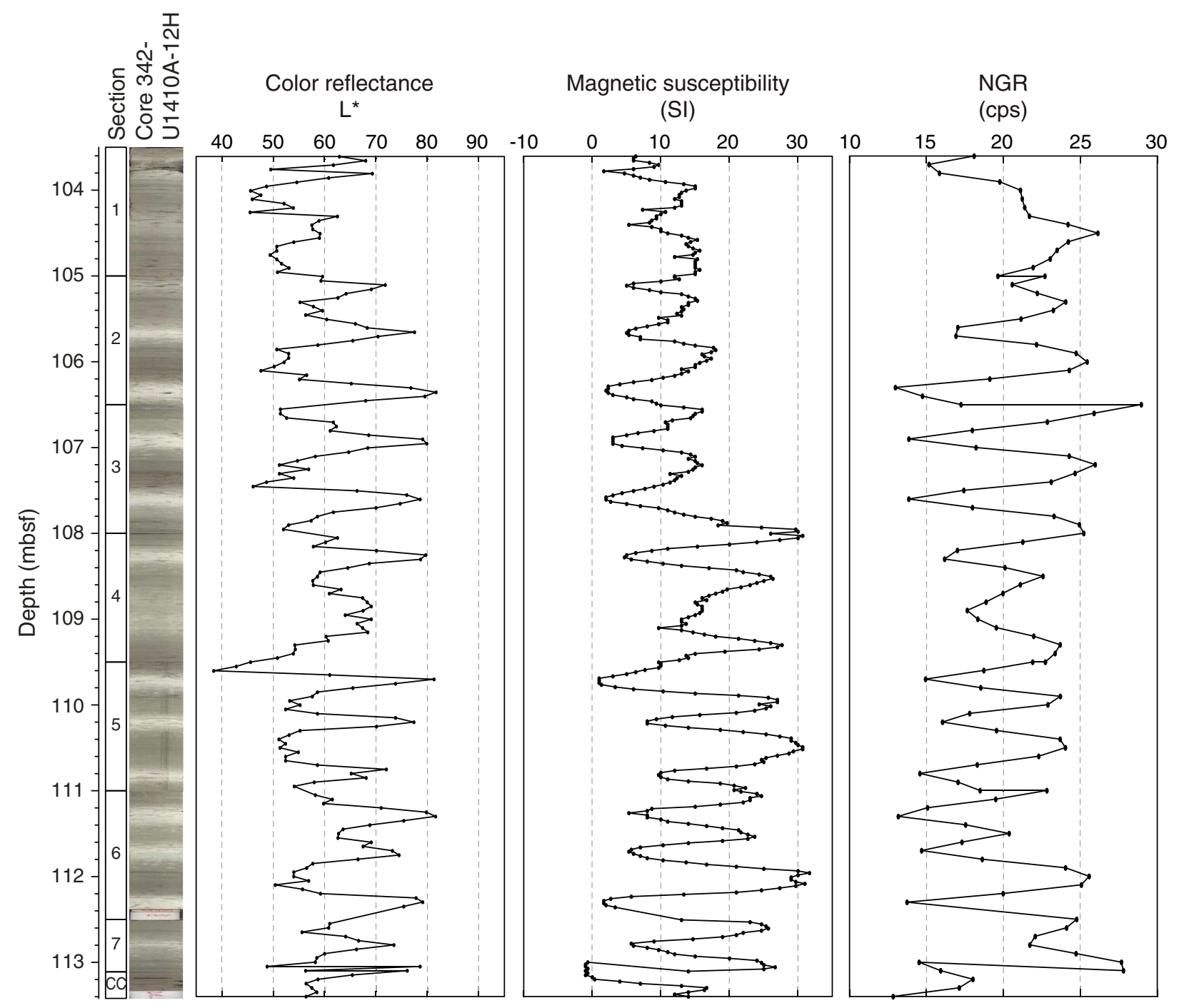


Figure F12. Core images of conglomerate with foraminiferal sand matrix bed in middle Eocene Unit III, Hole U1410A. Clasts are composed of nannofossil clay and clayey nannofossil ooze typical of Unit III. Calcareous nannofossil ages of a clast and the foraminiferal sand matrix are both Subzone NP15b.

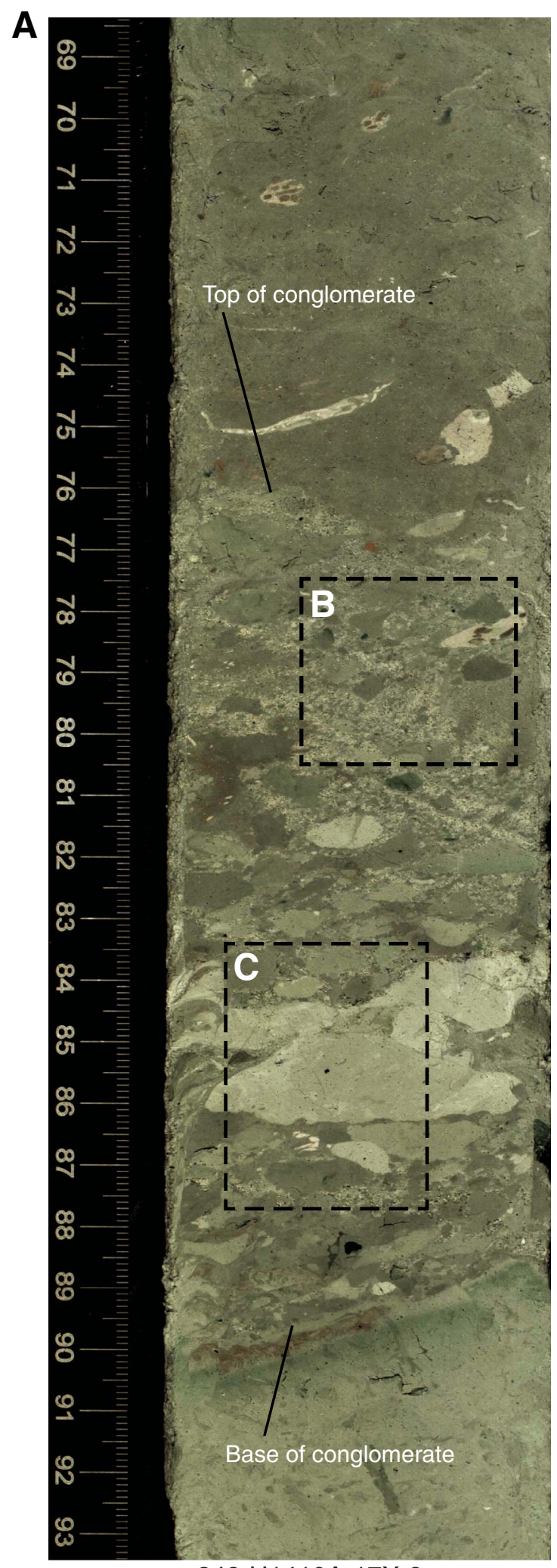

342-U1410A-17X-2
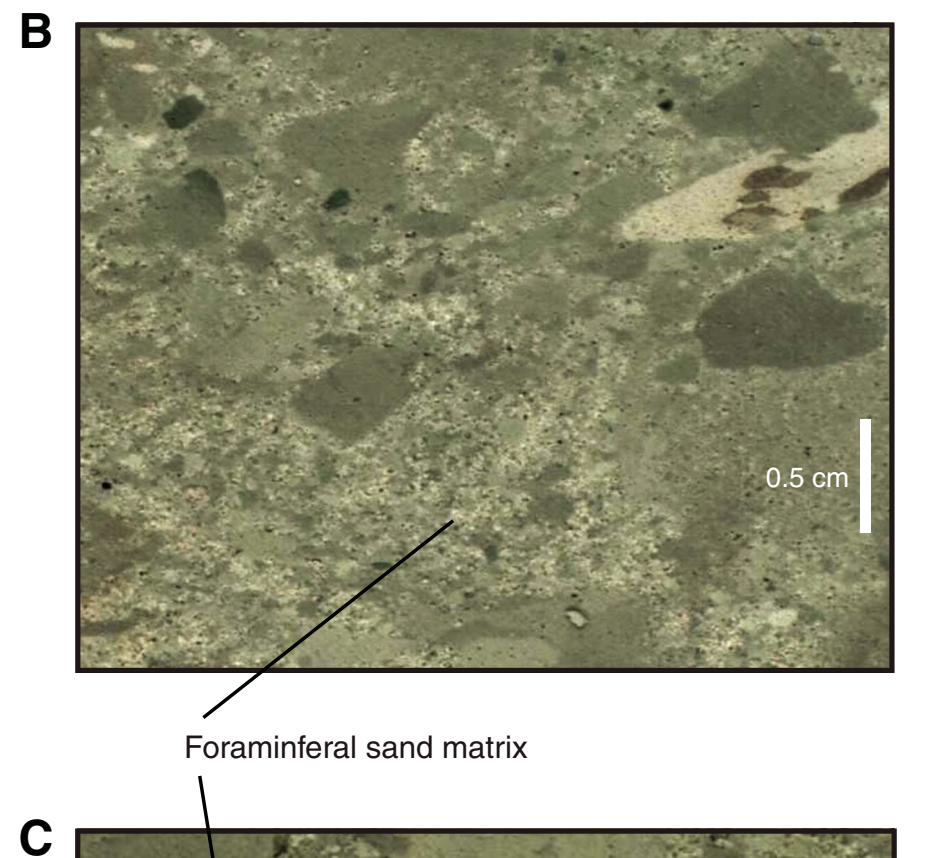

C

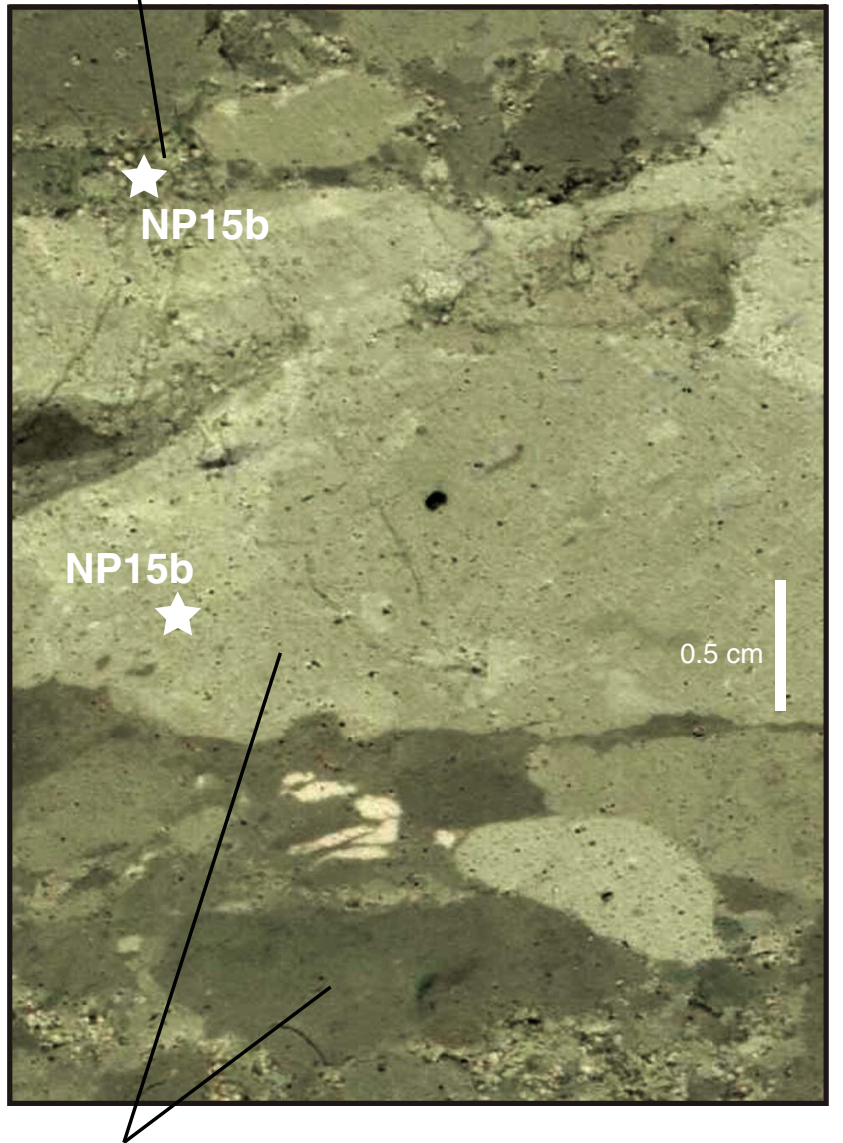

Clasts of nannofossil clay and clayey nannofossil ooze 
Figure F13. Integrated calcareous and siliceous microfossil biozonation, Site U1410.

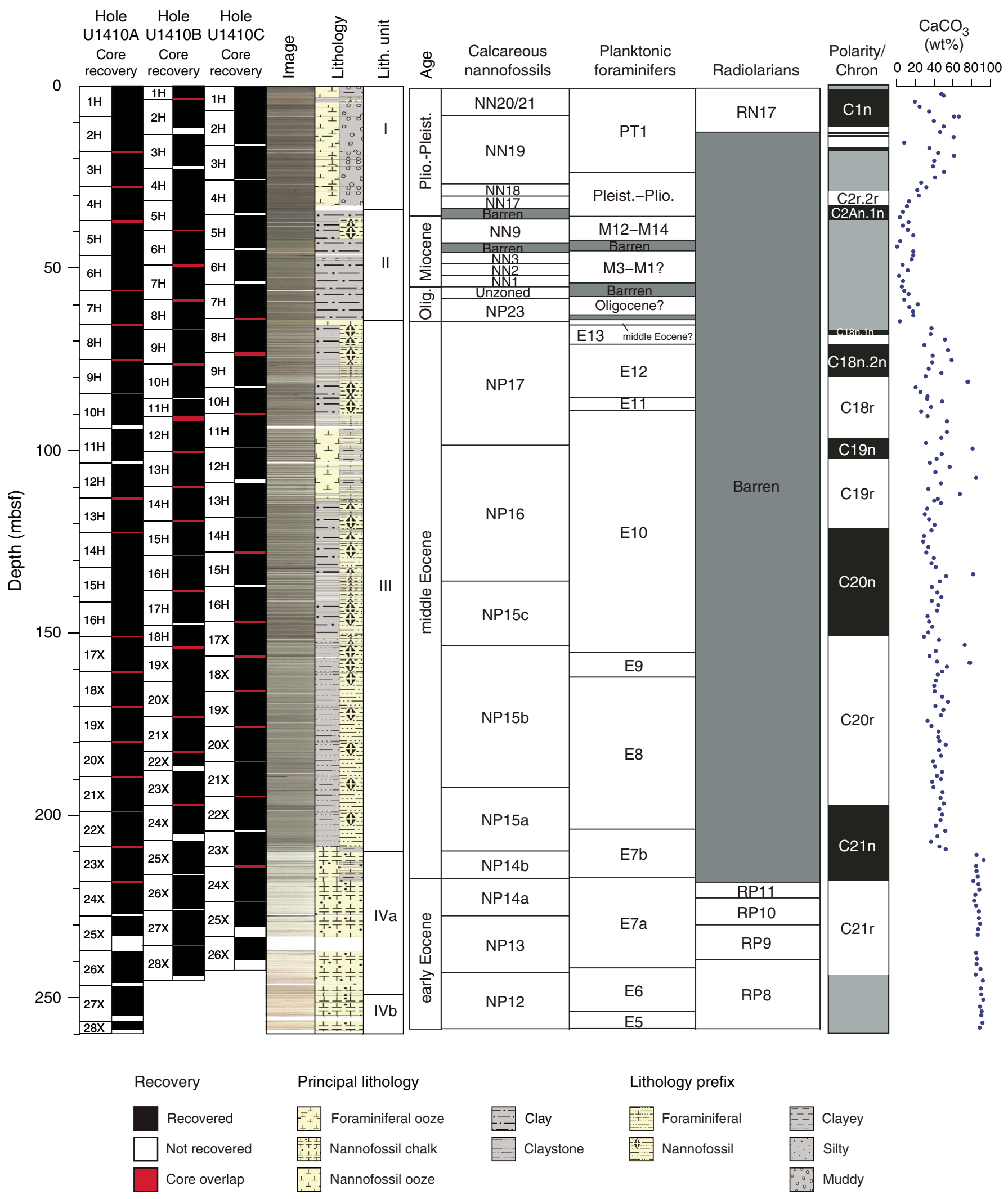


Figure F14. Group abundance and preservation of calcareous and siliceous microfossils, Site U1410. Abundance: $\mathrm{B}=\mathrm{barren}, \mathrm{P}=\mathrm{present}, \mathrm{R}=$ rare, $\mathrm{F}=$ few, $\mathrm{C}=$ common, $\mathrm{A}=$ abundant $\mathrm{D}=$ dominant. Preservation: $\mathrm{P}=$ poor, $\mathrm{M}=$ moderate, $\mathrm{G}=$ good, $\mathrm{VG}=$ very good.

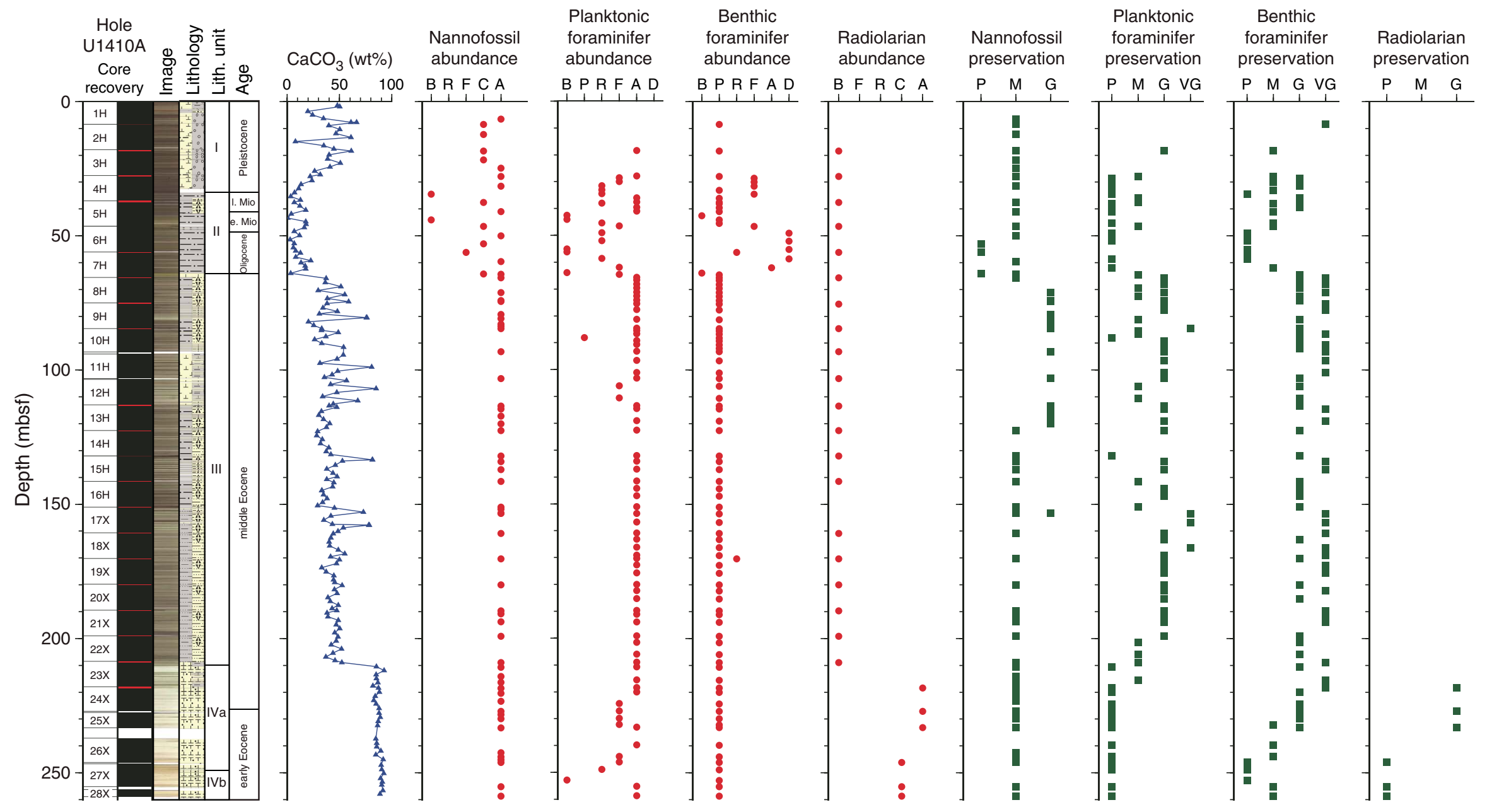


Figure F15. Plots of downhole variation of magnetic susceptibility and paleomagnetism data, Hole U1410A. Magnetization intensity, inclination, and declination are after $20 \mathrm{mT}$ demagnetization. Only oriented advanced piston corer (APC) intervals show directions in geographic coordinates. Directions from extended core barrel (XCB) intervals are shown in sample coordinates. For discrete sample data, if the samples were analyzed by principal component analysis (PCA; Kirschvink, 1980), then directions are shown according to PCA declination and inclination. Otherwise, directions following $20 \mathrm{mT}$ demagnetization are shown. Polarity: black $=$ normal chron, white $=$ reversed chron, gray $=$ unidentified interval .

Hole U1410A

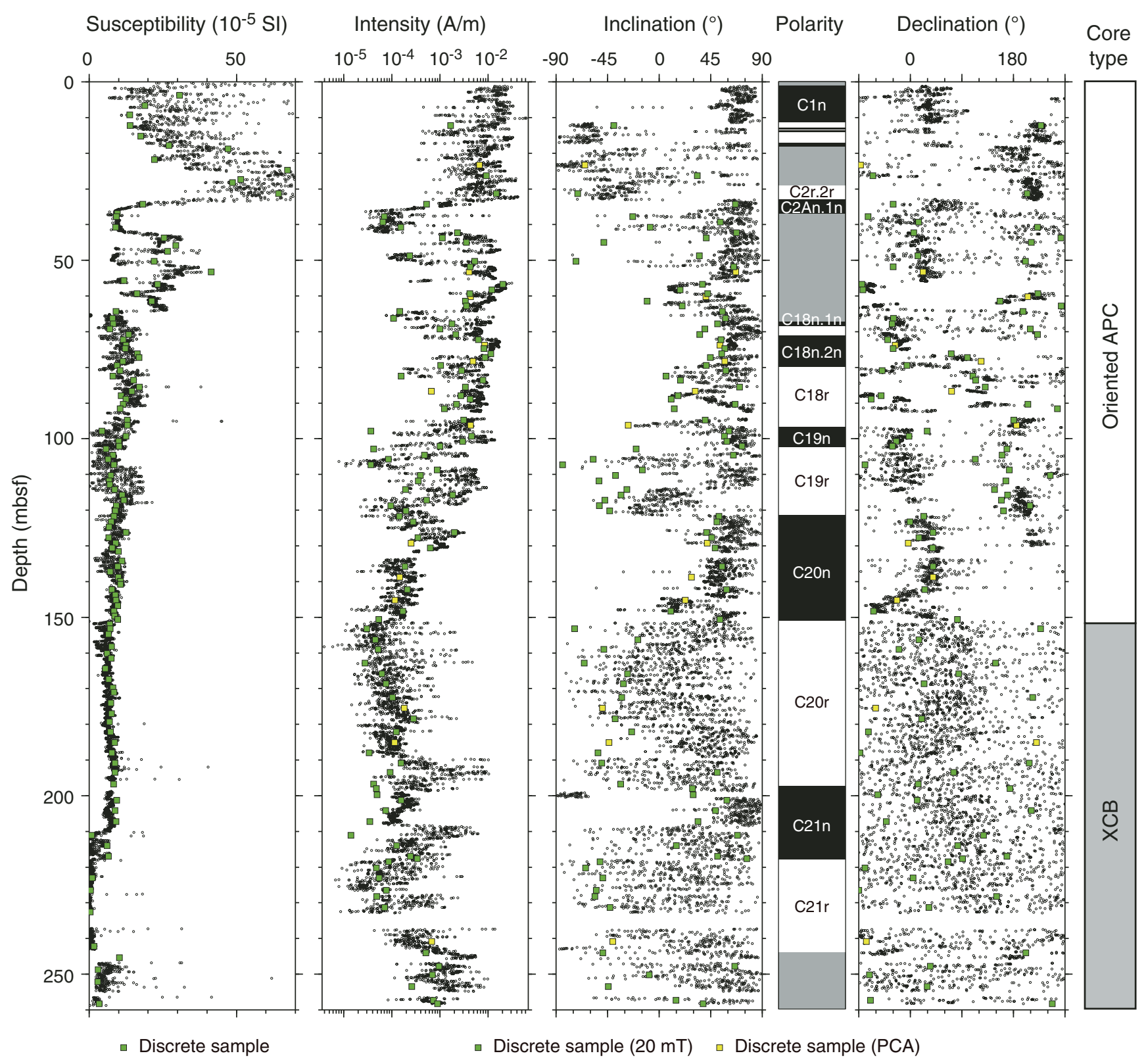


Figure F16. Plots of downhole variation of magnetic susceptibility and paleomagnetism data, Hole U1410B. Magnetization intensity, inclination, and declination are after $20 \mathrm{mT}$ demagnetization. Directions are shown in geographic coordinates for the oriented advanced piston corer (APC) intervals. XCB = extended core barrel. Polarity: black $=$ normal chron, white $=$ reversed chron, gray $=$ unidentified interval .

Hole U1410B

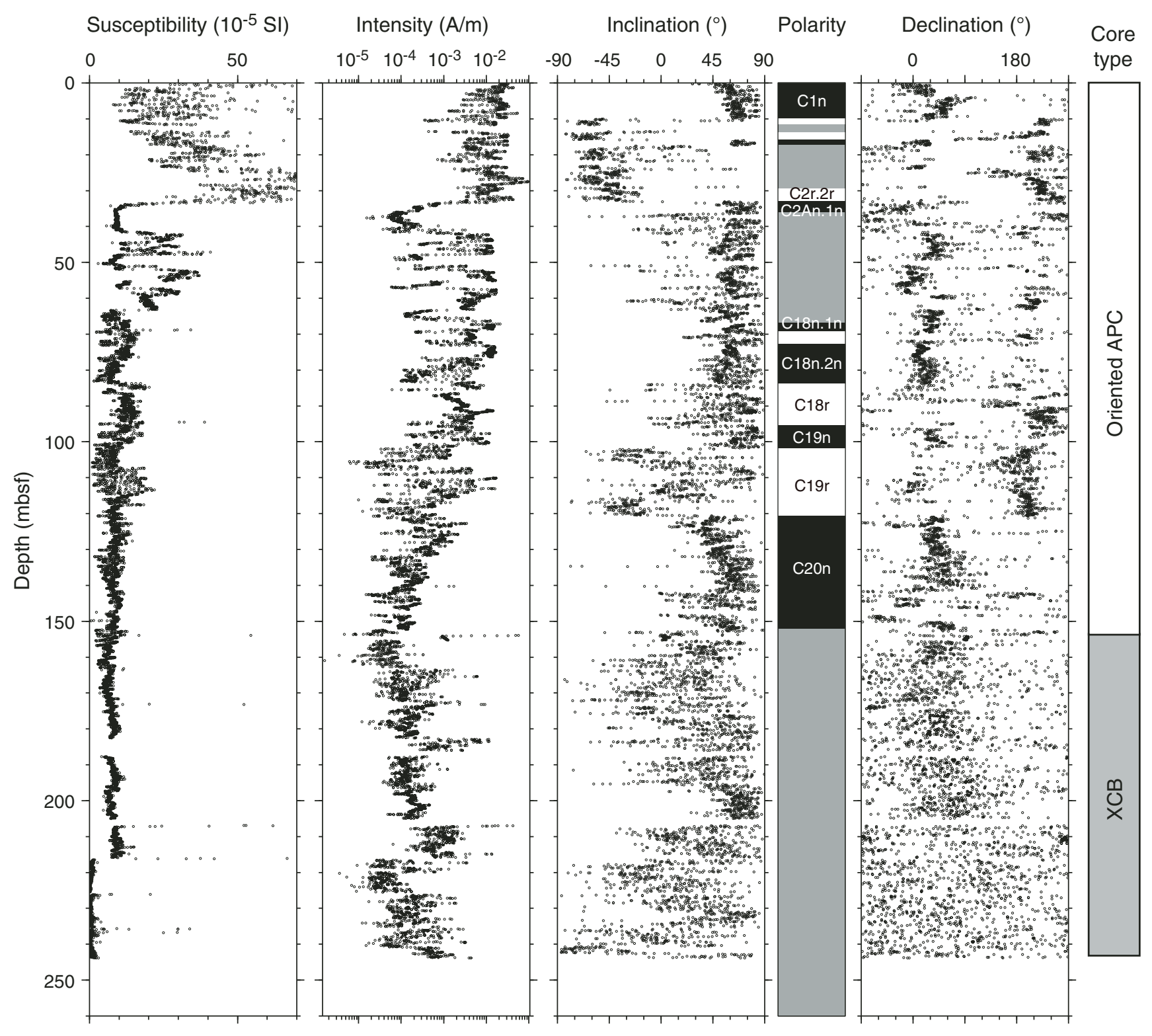


Figure F17. Plots of downhole variation of magnetic susceptibility and paleomagnetism data, Hole U1410C. Magnetization intensity, inclination, and declination are after $20 \mathrm{mT}$ demagnetization. Directions are shown in sample coordinates. APC = advanced piston corer, $\mathrm{XCB}=$ extended core barrel. Polarity: black = normal chron, white $=$ reversed chron, gray $=$ unidentified interval.

Hole U1410C

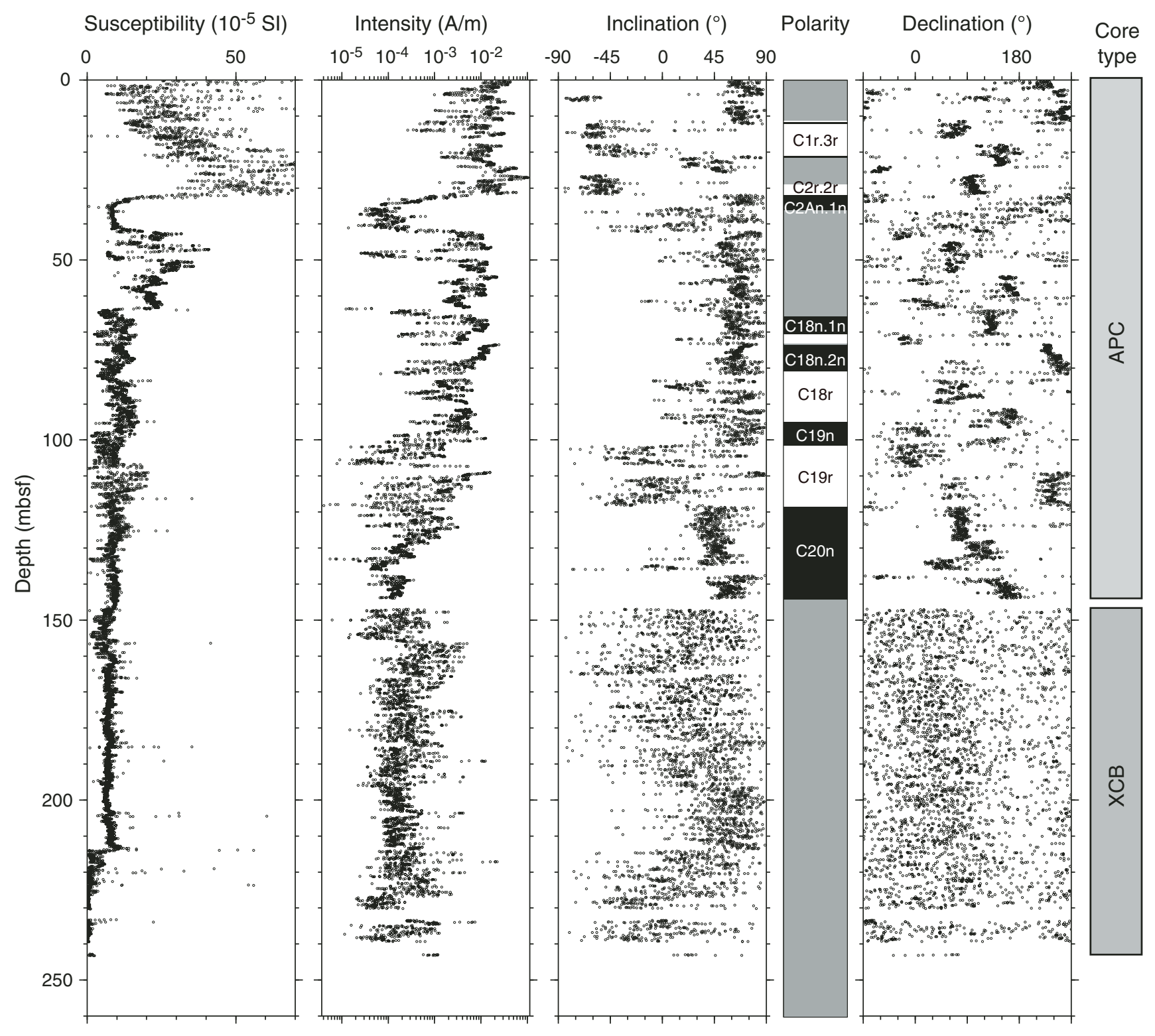


Figure F18. Plots of representative alternating field (AF) demagnetization results for discrete paleomagnetism samples, Site U1410. Upper plots show intensity variation with progressive demagnetization, and lower plots show vector endpoints of paleomagnetism directions on orthogonal vector diagrams (i.e., Zijderveld plots). Vector diagrams indicate reasonably resolved characteristic remanent magnetization (ChRM) directions for the (A) normal and (B) reversed chrons from the advanced piston corer intervals, whereas (C) some samples do not show stable component. Solid circles $=$ horizontal projections, open circles $=$ vertical projections, gray circles $=$ data not used to calculate ChRM direction, black dashed line $=$ ChRM direction. Inc $=$ inclination, Dec $=$ declination, $\mathrm{MAD}=$ maximum angle of deviation.
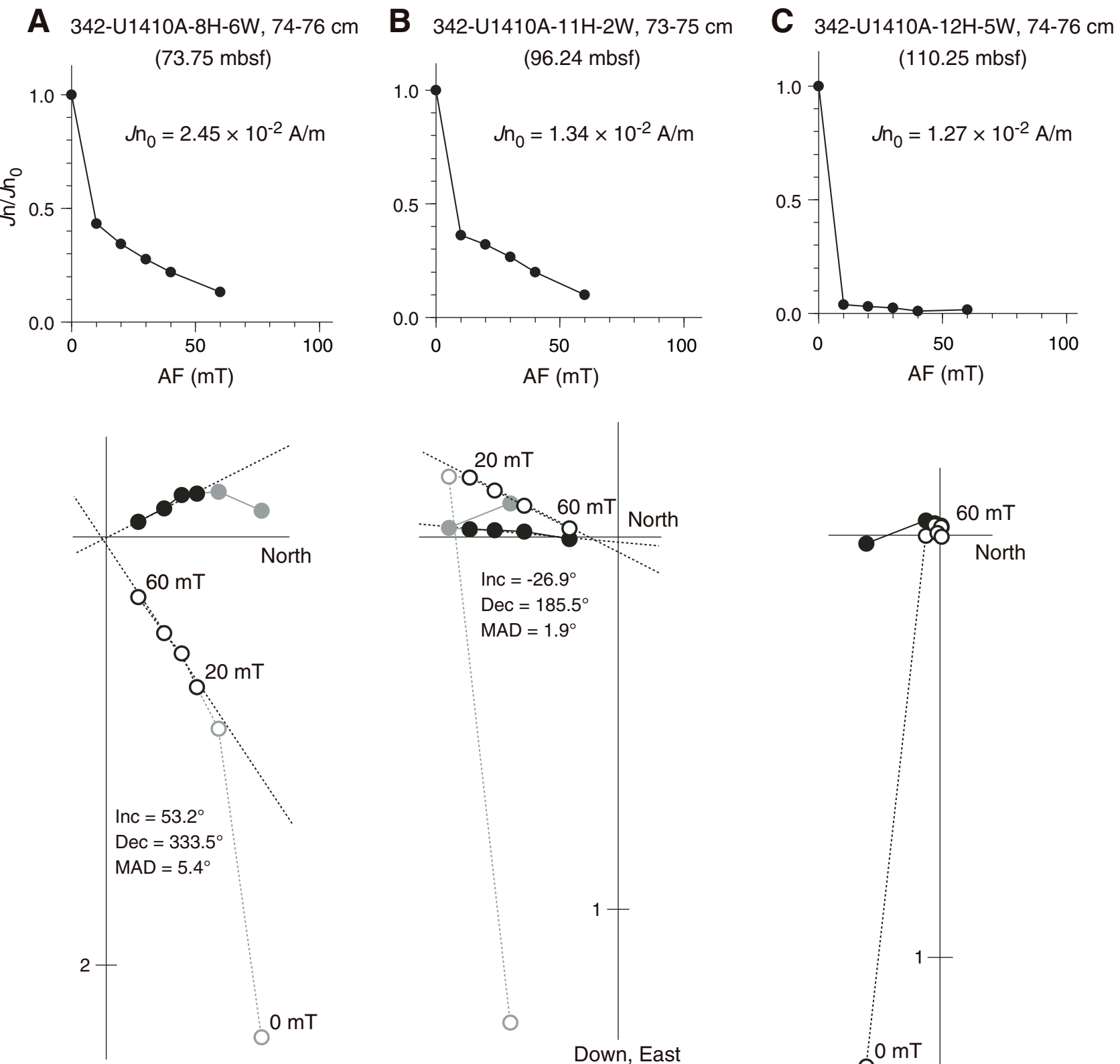

Down, East
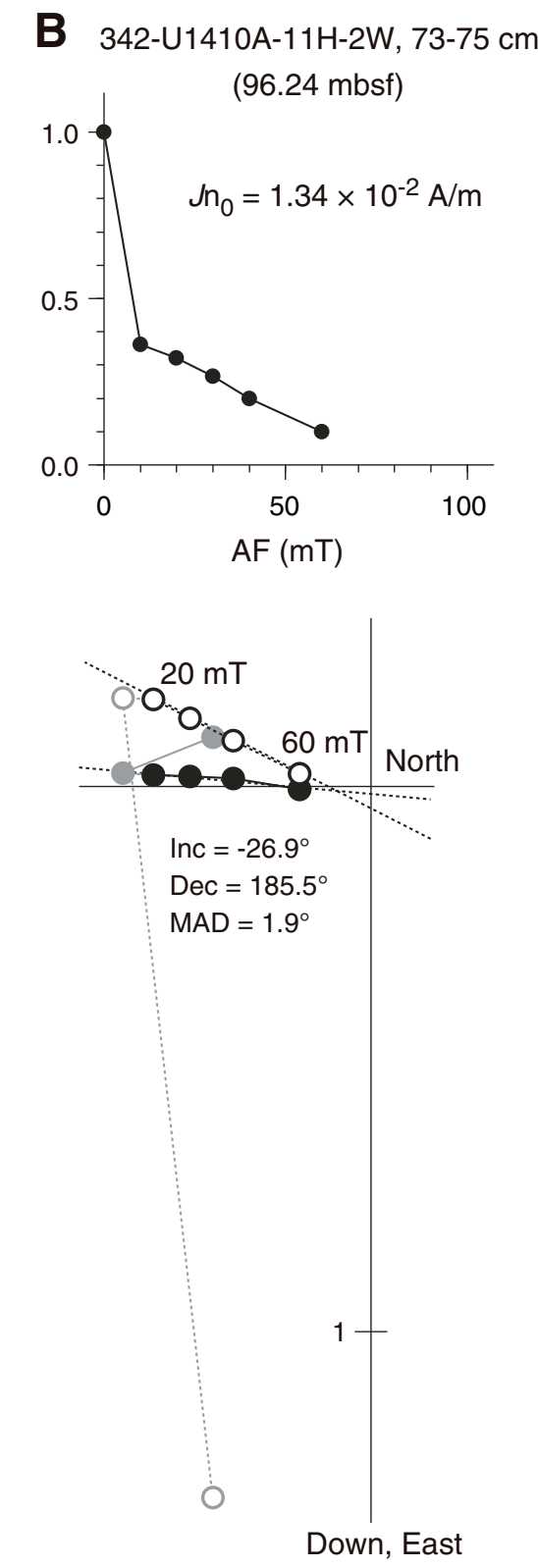

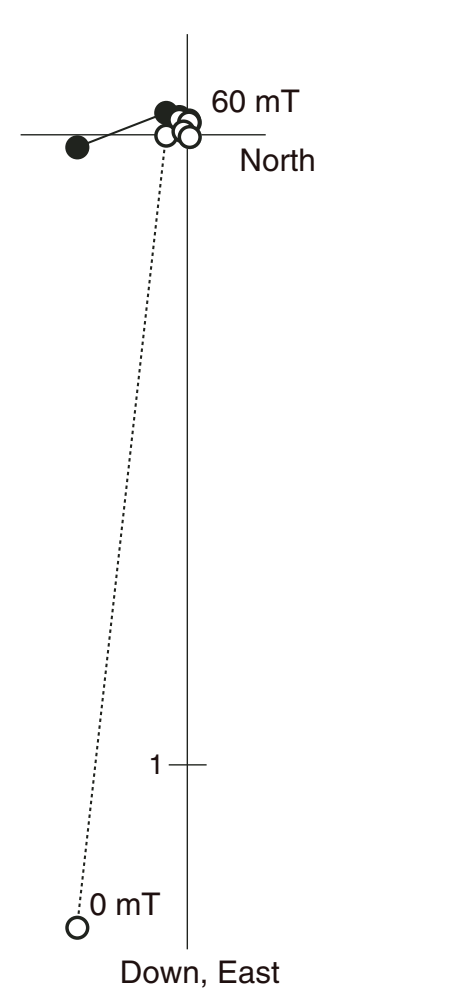


Figure F19. Illustration of magnetostratigraphy, Site U1410. Core recovery: black $=$ recovered, white $=$ not recovered, red = core overlap.

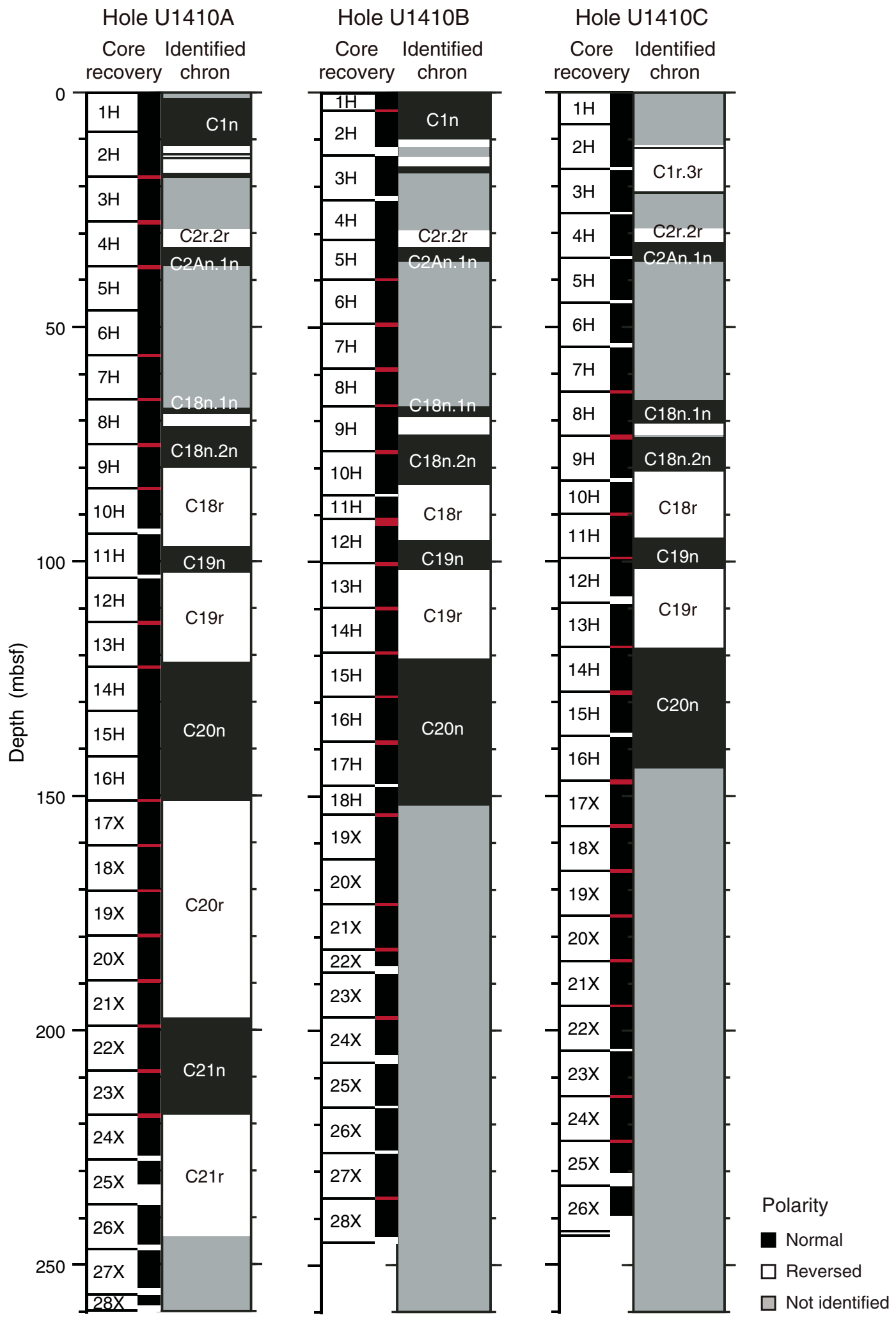


Figure F20. Plots of downhole variation of declination, inclination, and magnetization intensity after 20 mT demagnetization during the Chron C18n.1n-C18n.1r-C18n.2n geomagnetic field transitions in Hole U1410B and at Site U1408. Polarity: black = normal chron, white = reversed chron, gray $=$ transitional period.

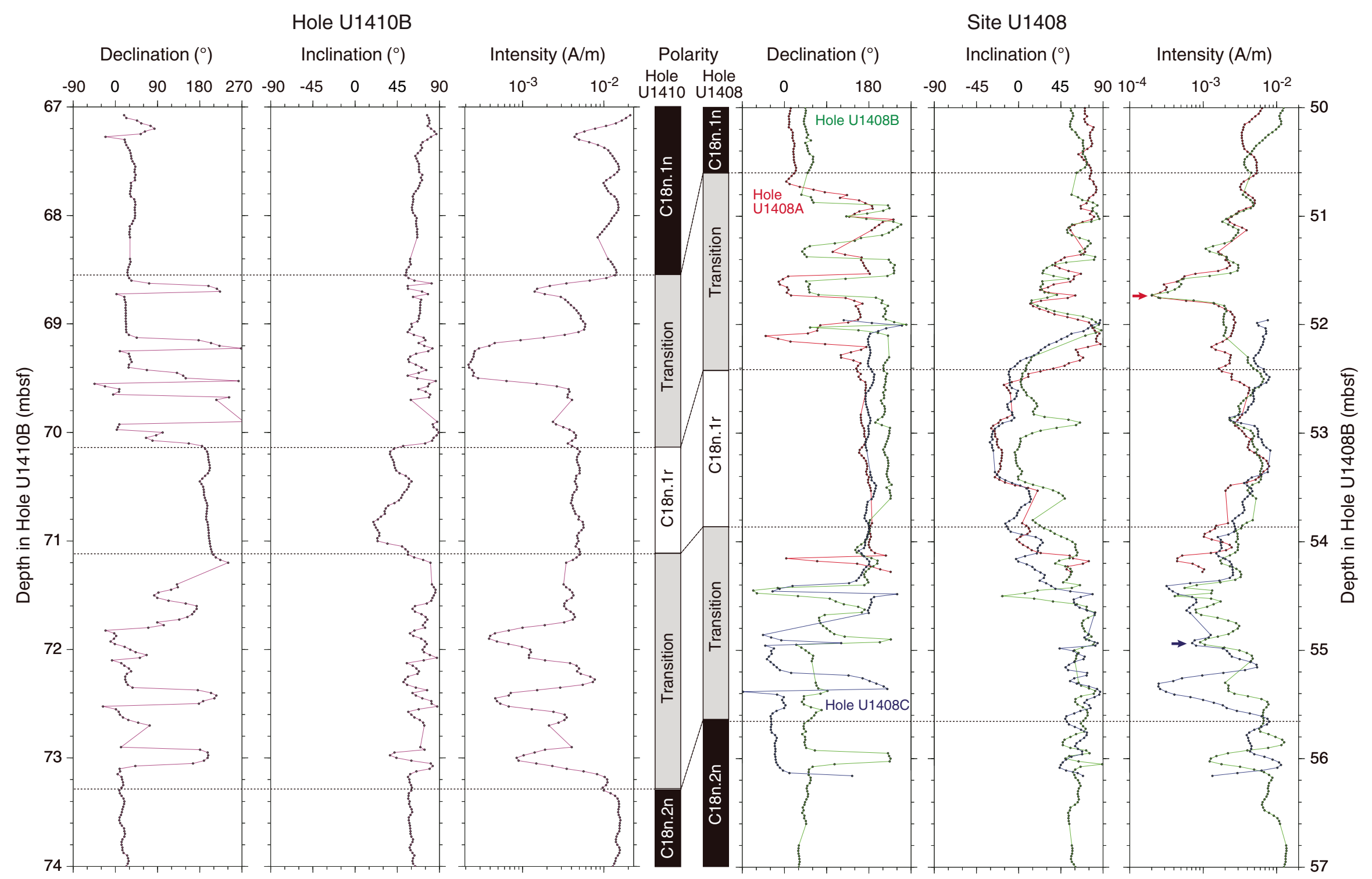


Figure F21. Plots of anisotropy of magnetic susceptibility vs. depth, Hole U1410A. Separation of eigenvalues is related to the shape and degree of the magnetic fabric (see "Paleomagnetism" in the "Methods" chapter [Norris et al., 2014a]). For example, if $\tau_{1}$ and $\tau_{2}$ are close or indistinguishable but distinct from $\tau_{3}$, then the bulk fabric is oblate. Lithostratigraphic units are described in "Lithostratigraphy." Eigenvalues: $\tau_{1}=$ maximum, $\tau_{2}$ $=$ intermediate, $\tau_{3}=$ minimum. $\mathrm{V}_{3}=$ minimum eigenvector, $P=$ degree of anisotropy $\left(\tau_{1} / \tau_{3}\right)$. APC $=$ advanced piston corer, $\mathrm{XCB}=$ extended core barrel.

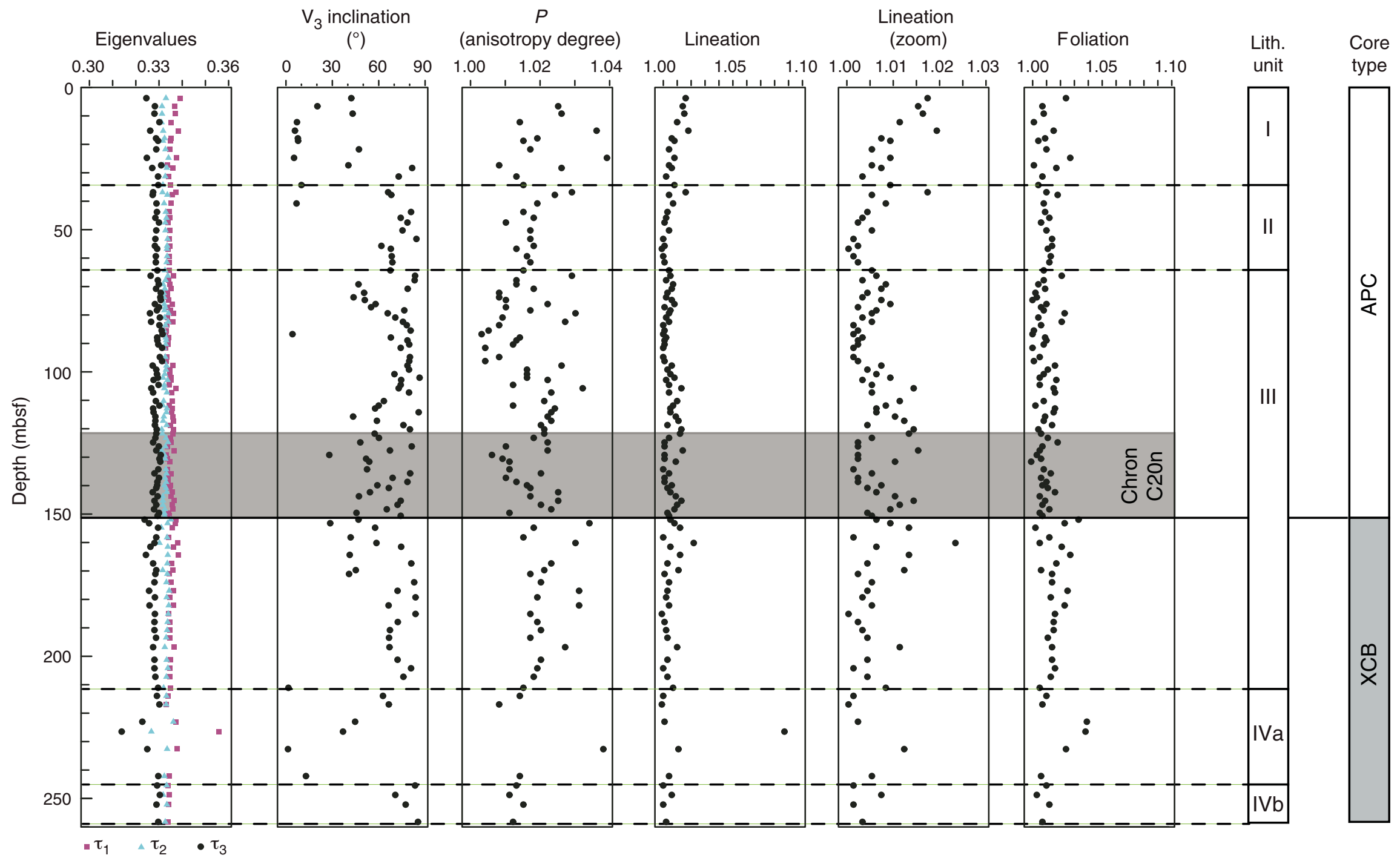


Figure F22. Age-depth model for Hole U1410A showing biostratigraphic and magnetostratigraphic datums. Also shown are estimated linear sedimentation rates for line segments based on the datums listed in Table T16.

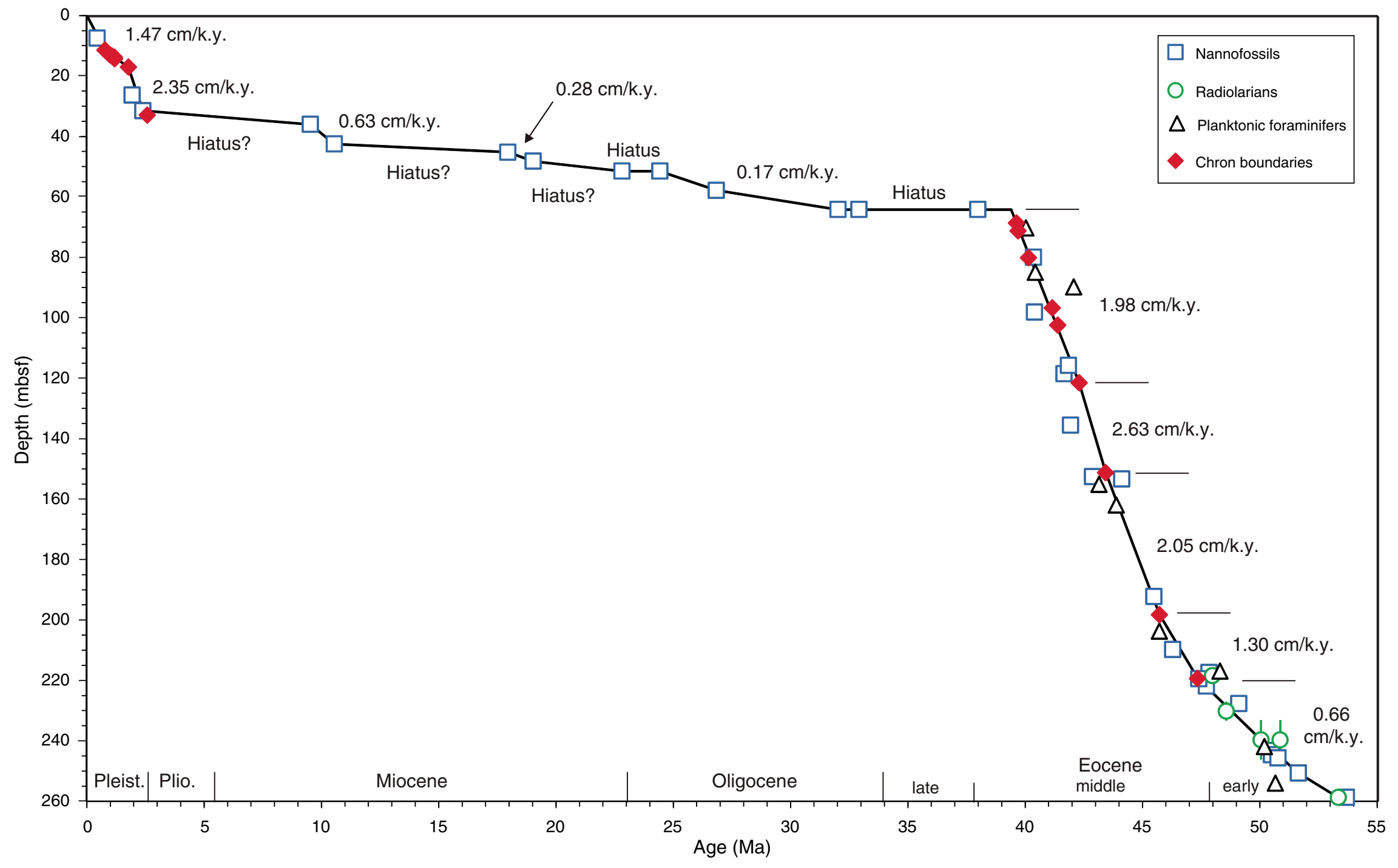


Figure F23. Linear sedimentation rate (LSR), dry bulk density (DBD), carbonate content, and mass accumulation rate (MAR) for carbonate and noncarbonate components at a time step of 200 k.y., Hole U1410A. Solid black diamonds show the inflection points in estimated LSR, DBD, and carbonate content. Geologic ages are on the GTS2012 timescale (Gradstein et al., 2012). CAR = carbonate mass accumulation rate, nCAR = noncarbonate mass accumulation rate.
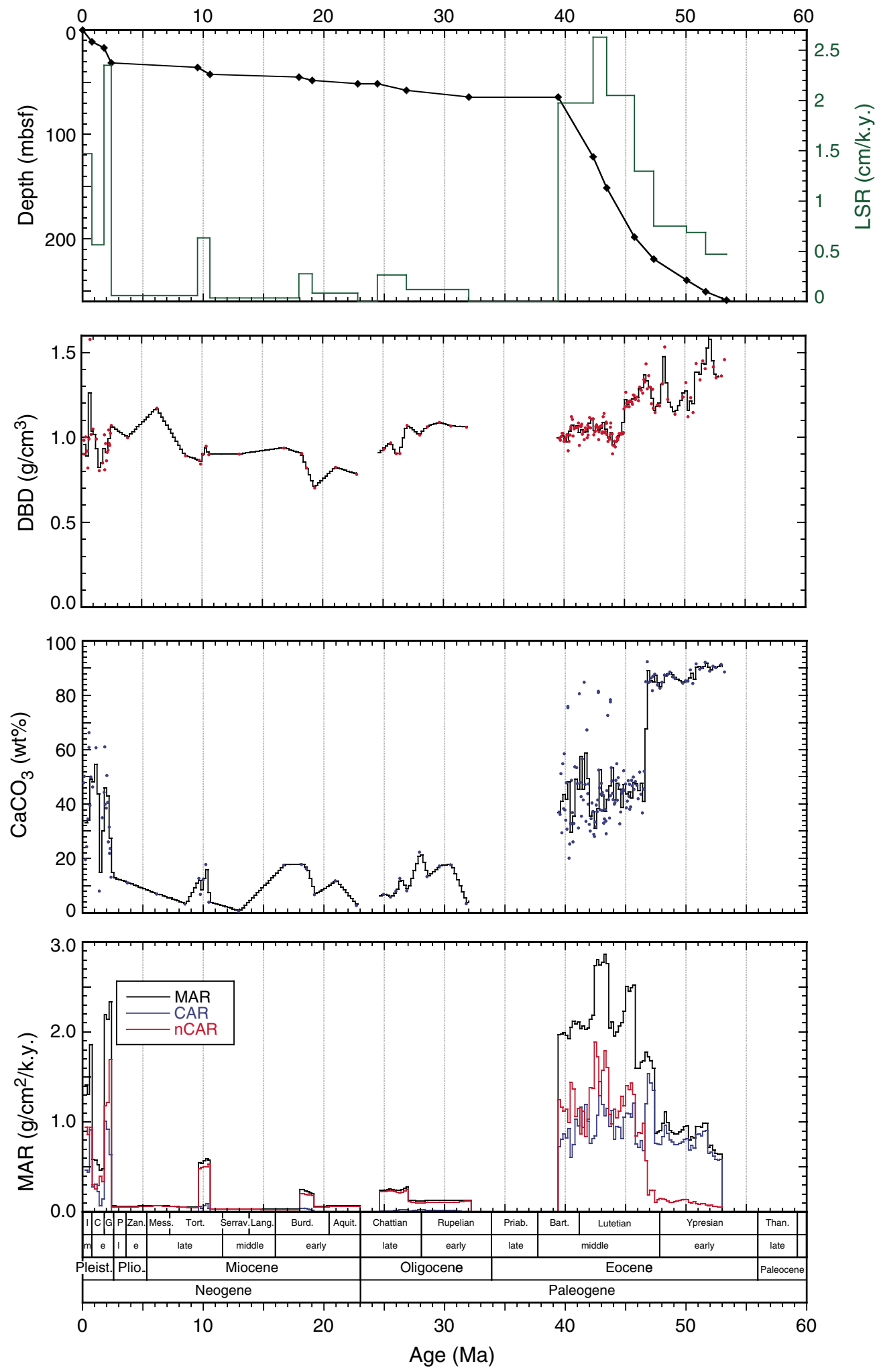
Figure F24. Plots of interstitial water constituent concentrations, Hole U1410A.
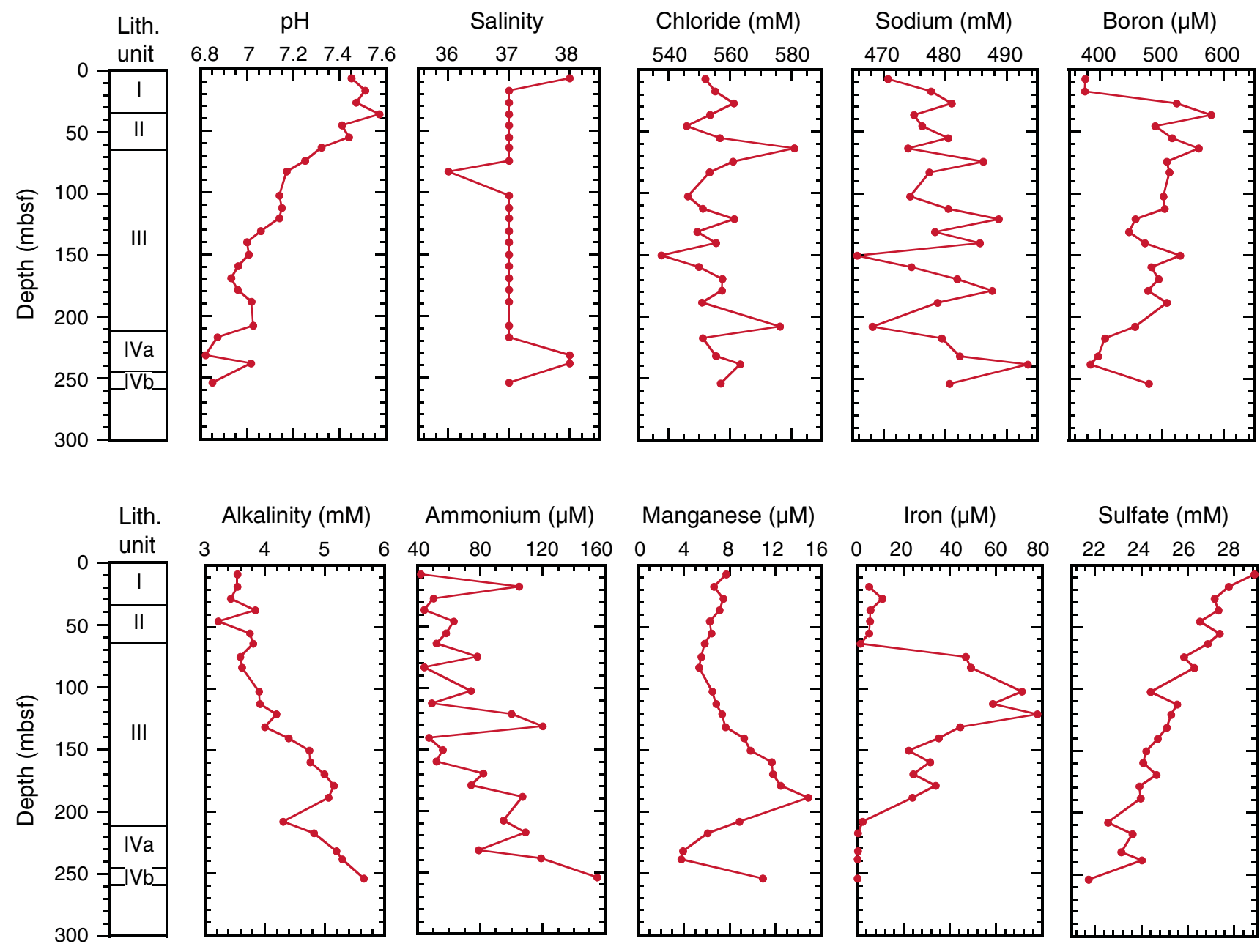

Ammonium $(\mu \mathrm{M})$
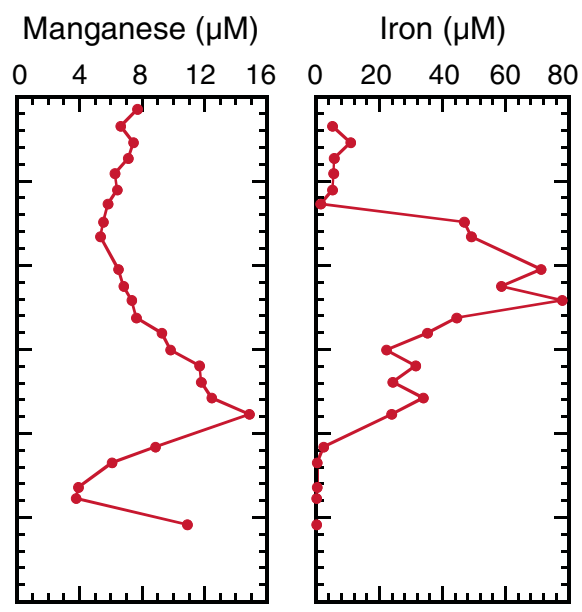

Sulfate $(\mathrm{mM})$
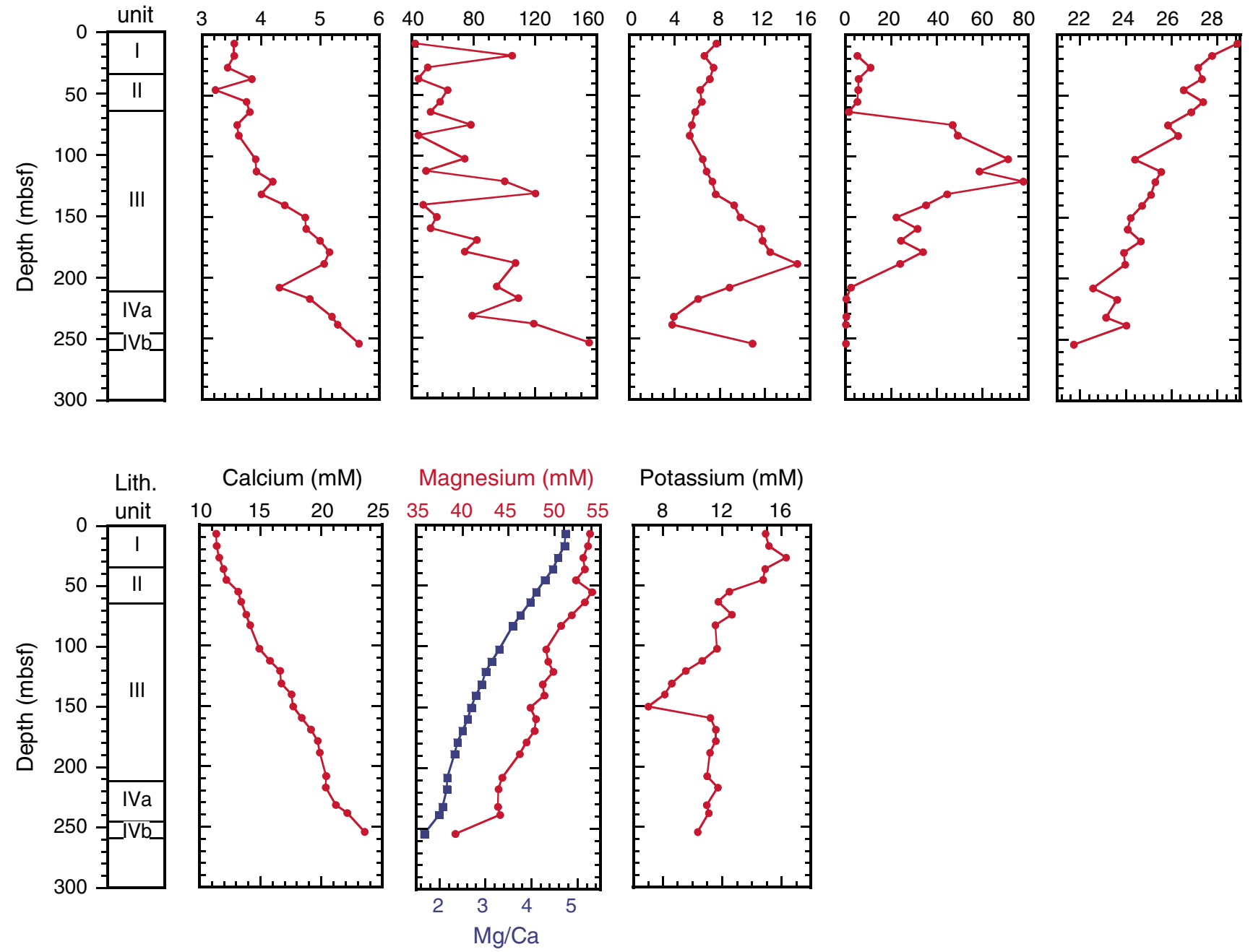
Figure F25. Plots of sedimentary carbonate, total organic carbon (TOC), and total nitrogen contents, Hole U1410A. Core recovery: black $=$ recovered, white $=$ not recovered, red $=$ core overlap.

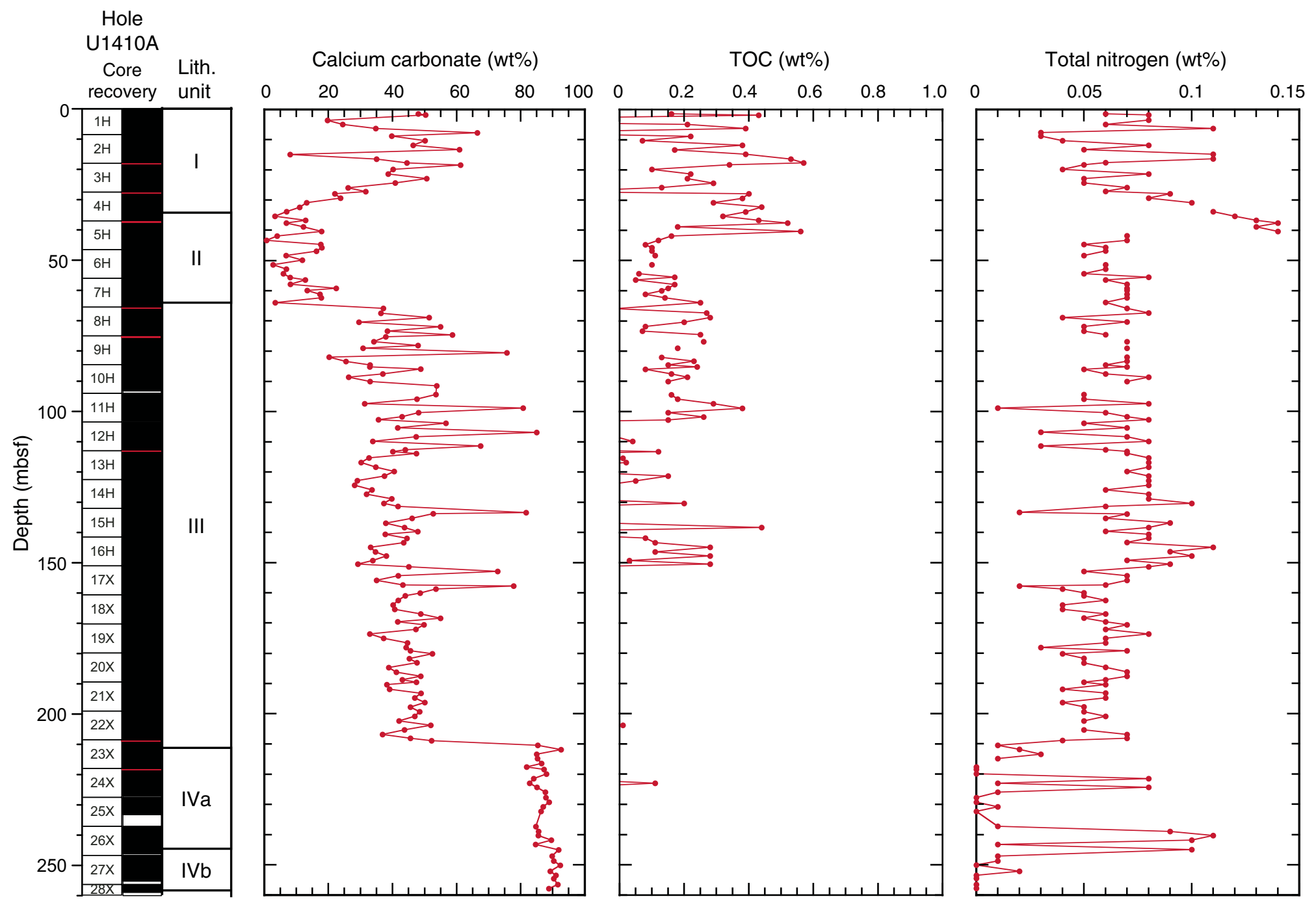


Figure F26. Plots of magnetic susceptibility (MS; truncated at 160 IU), bulk density, porosity, water content, and grain density, Site U1410. Core recovery: black $=$ recovered, white $=$ not recovered, red $=$ core overlap. Bulk density: gray line $=$ gamma ray attenuation bulk density from WholeRound Multisensor Logger, black circles = moisture and density bulk density from discrete samples. Horizontal gray lines indicate lithostratigraphic unit boundaries (see "Lithostratigraphy"). APC = advanced piston corer, XCB = extended core barrel.
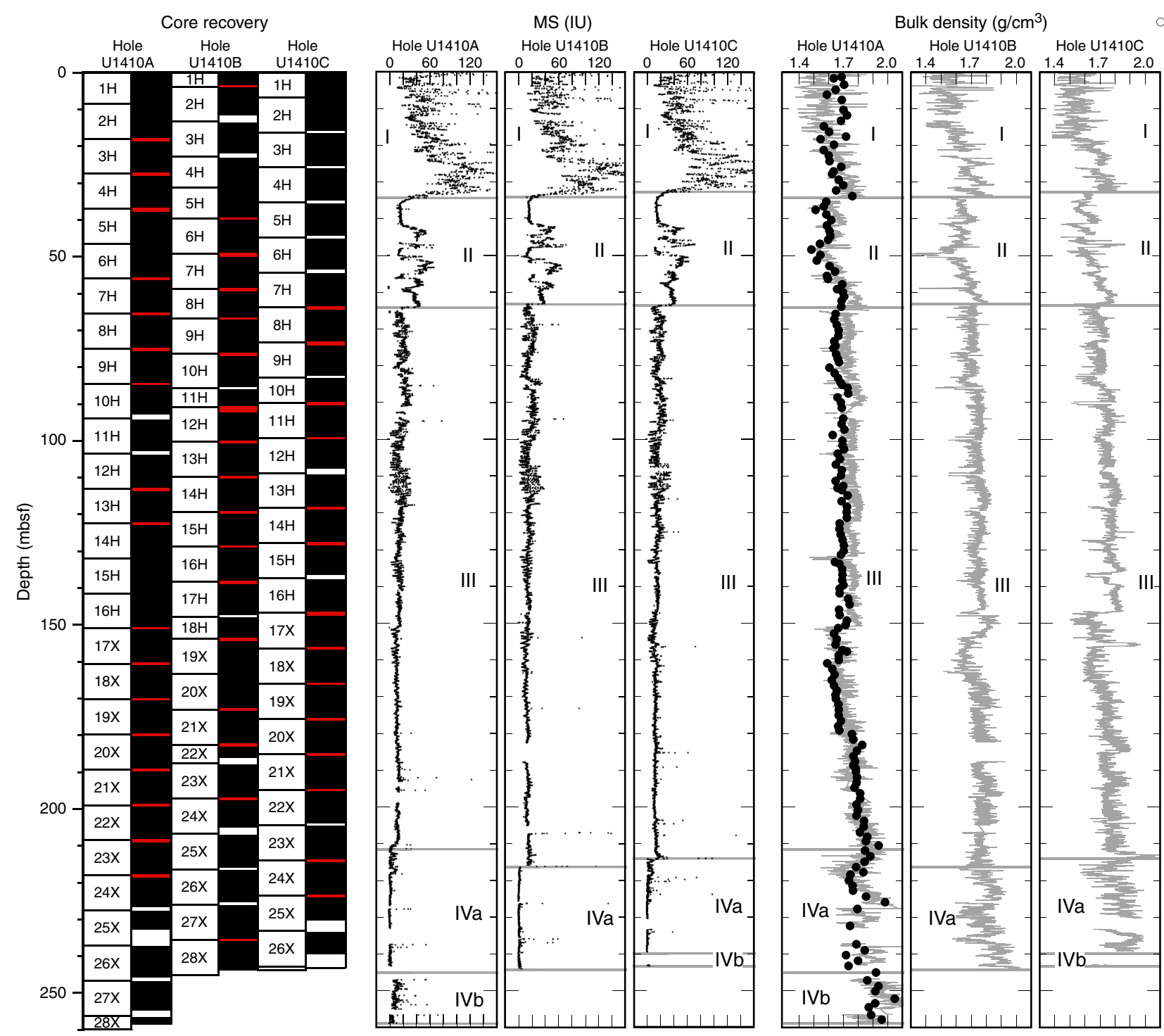

Water content ( $w$ t\%) Grain density ( $\left.\mathrm{g} / \mathrm{cm}^{3}\right)$
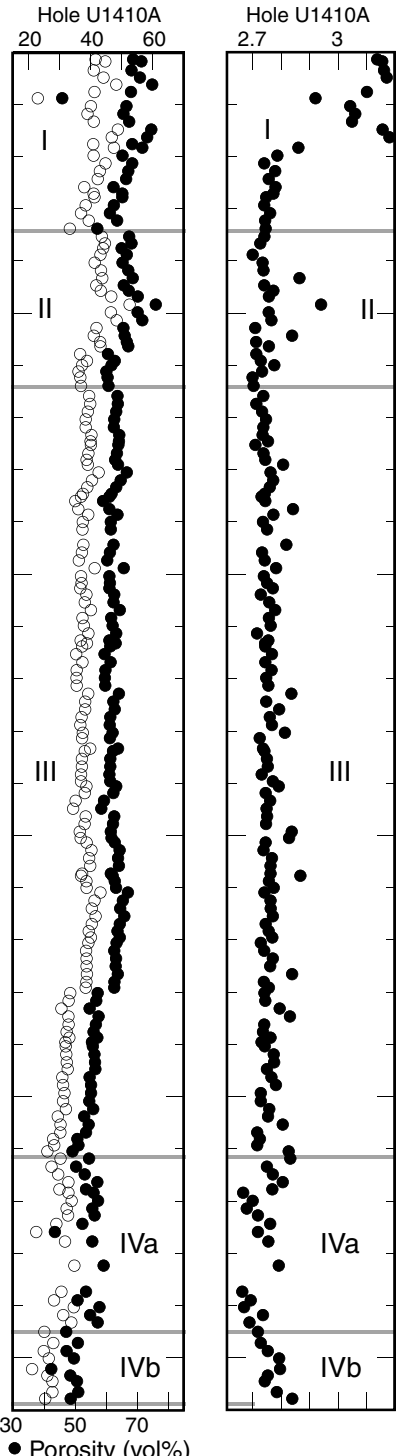

Coring system Site U1410

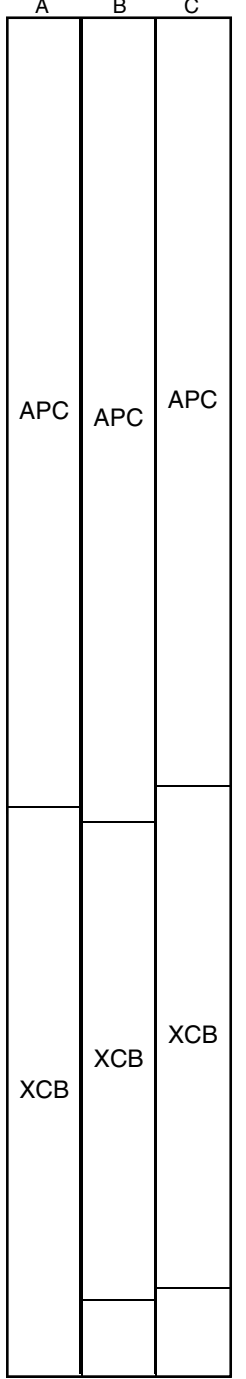


Figure F27. Plots of magnetic susceptibility (MS), $P$-wave velocity (gray line $=P$-wave logger data from whole-round sections, black circles $=P$-wave caliper data from section halves), and natural gamma radiation (NGR), Site U1410. Core recovery: black $=$ recovered, white $=$ not recovered, red $=$ core overlap. Horizontal gray lines indicate lithostratigraphic unit boundaries (see "Lithostratigraphy"). APC = advanced piston corer, $\mathrm{XCB}=$ extended core barrel.
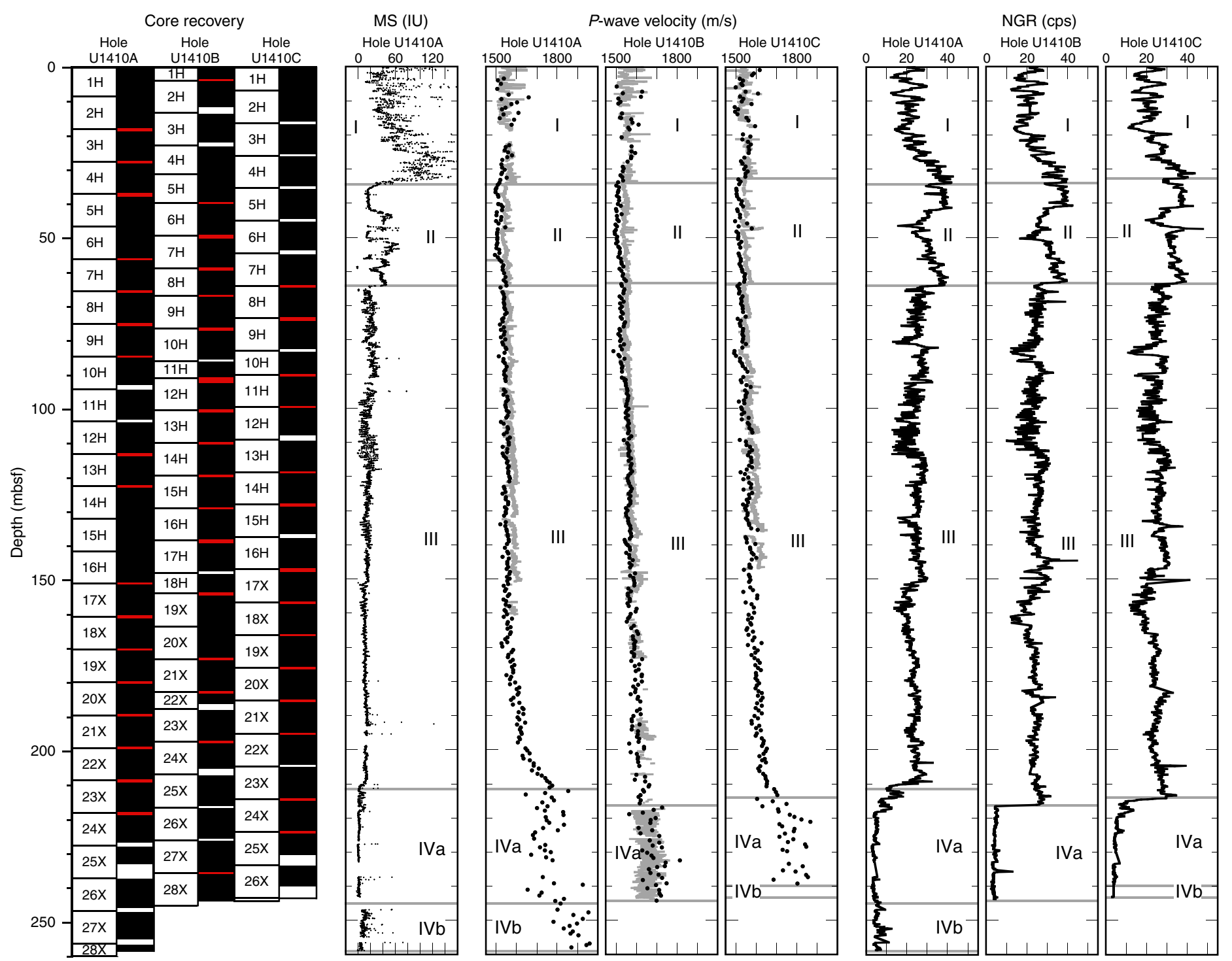

Coring system Site U1410

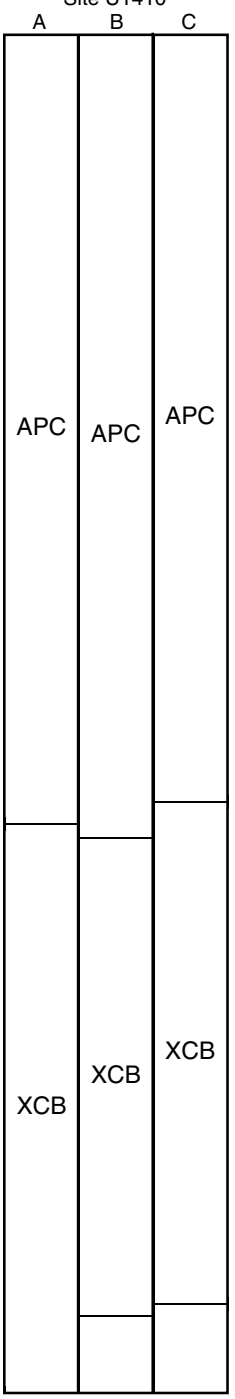


Figure F28. Plots of magnetic susceptibility (MS) and color reflectance $\left(a^{*}, b^{*}\right.$, and $\left.L^{*}\right)$, Site U1410. Core recovery: black $=$ recovered, white $=$ not recovered, red = core overlap. Horizontal gray lines indicate lithostratigraphic unit boundaries (see "Lithostratigraphy"). APC $=$ advanced piston corer, $\mathrm{XCB}=$ extended core barrel.
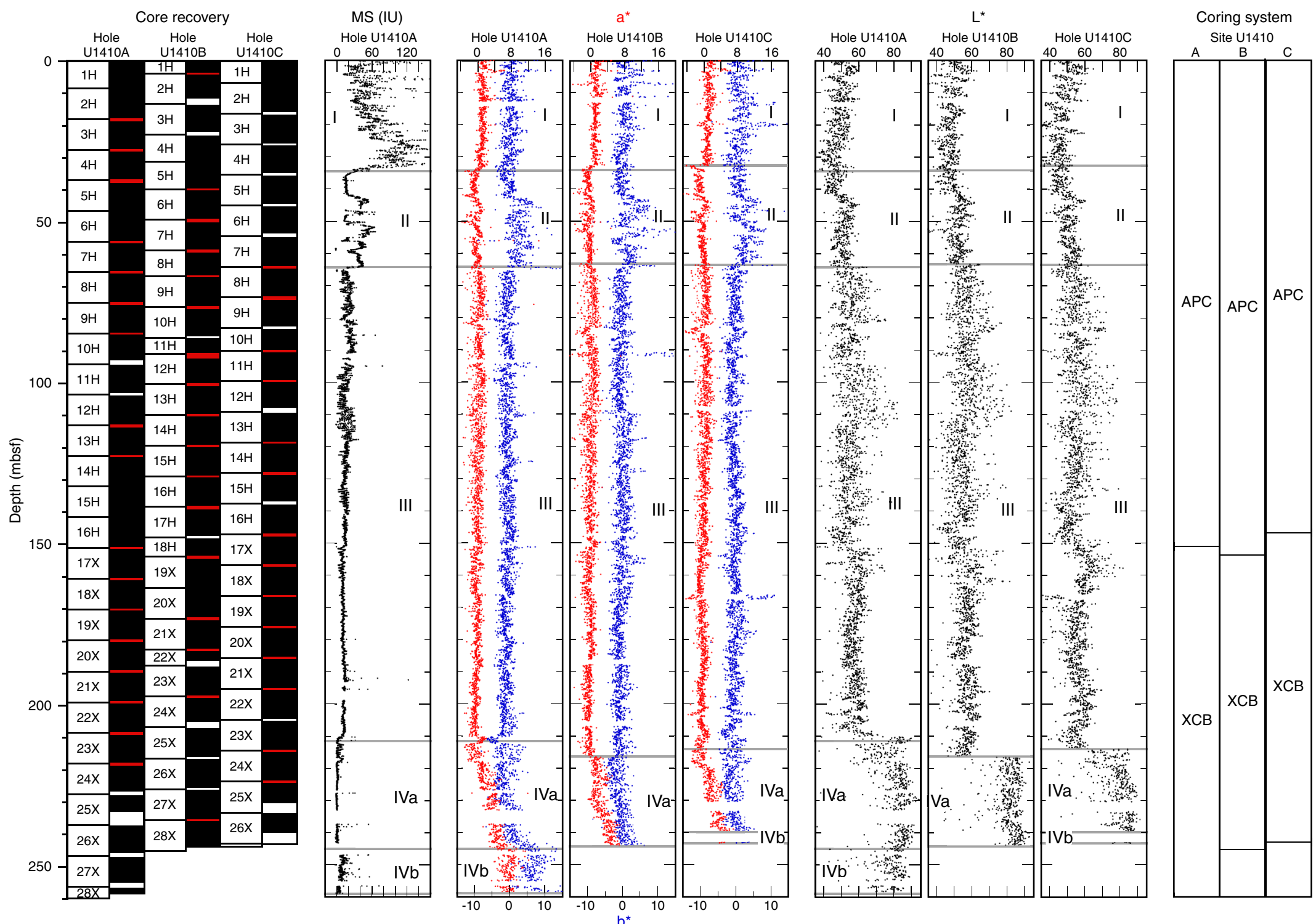
Figure F29. Plot of thermal conductivity measurements, Hole U1410A. Core recovery: black = recovered, white $=$ not recovered, red = core overlap. Blue line is the smooth-curve fit for the data set. Horizontal gray lines indicate lithostratigraphic unit boundaries (see "Lithostratigraphy").

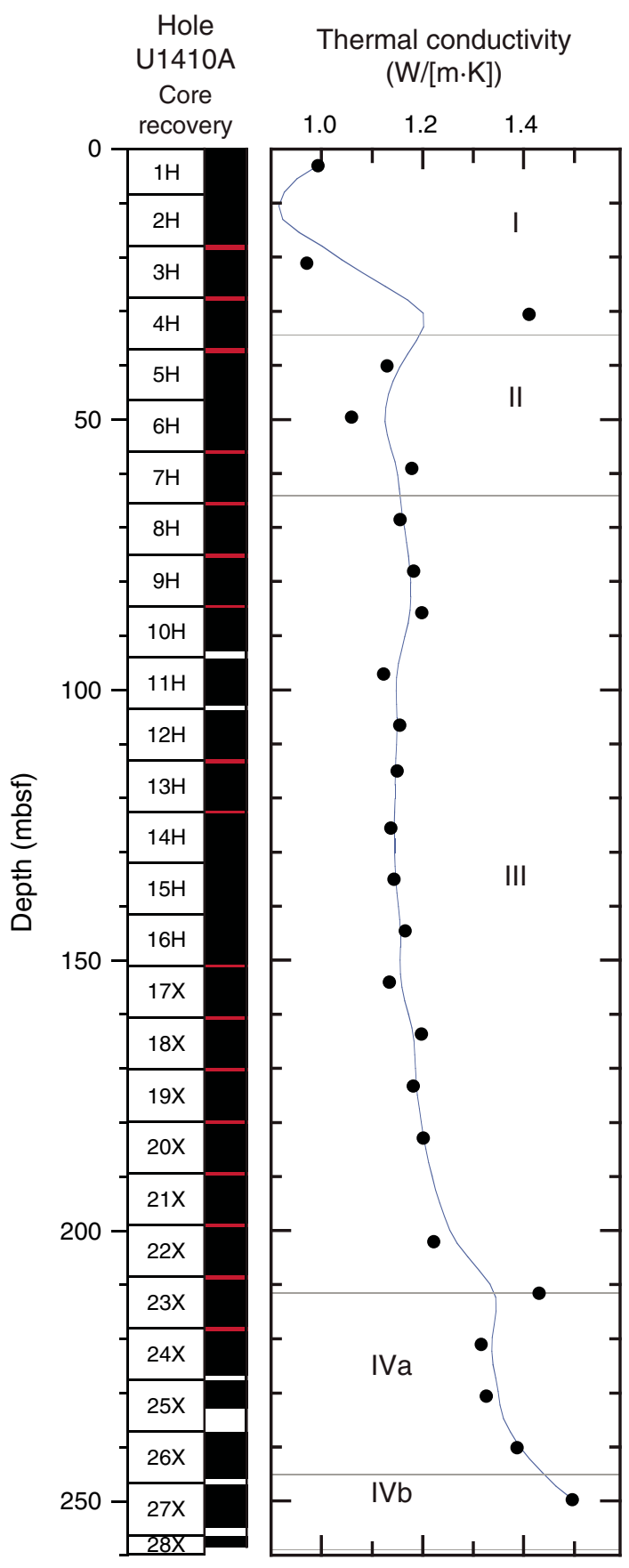


Figure F30. Plot of thermal conductivity vs. gamma ray attenuation (GRA) bulk density, Hole U1410A. Black line is the linear-curve fit for this data set, and $R^{2}$ is the correlation coefficient.

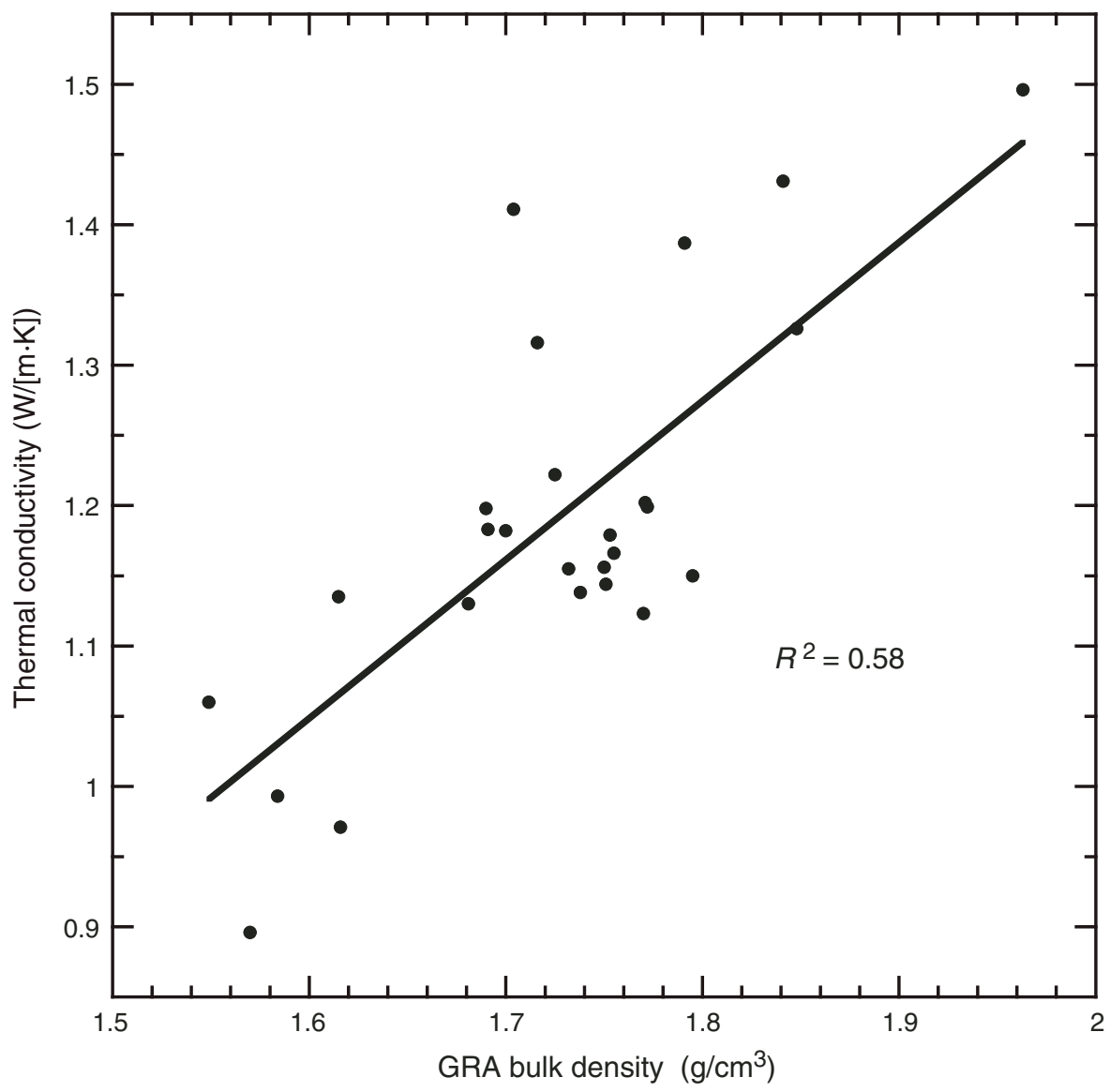


Figure F31. Plots of natural gamma radiation (NGR) data, Site U1410. Top panels show the spliced section for each interval of the splice. Bottom panels show all complete NGR records. Data from Holes U1410B and U1410C are offset by 25 and $50 \mathrm{cps}$, respectively, to aid visualization. Open circles indicate core tops, excluding culled data from disturbed intervals. A. 0-50 m CCSF. (Continued on next five pages.)
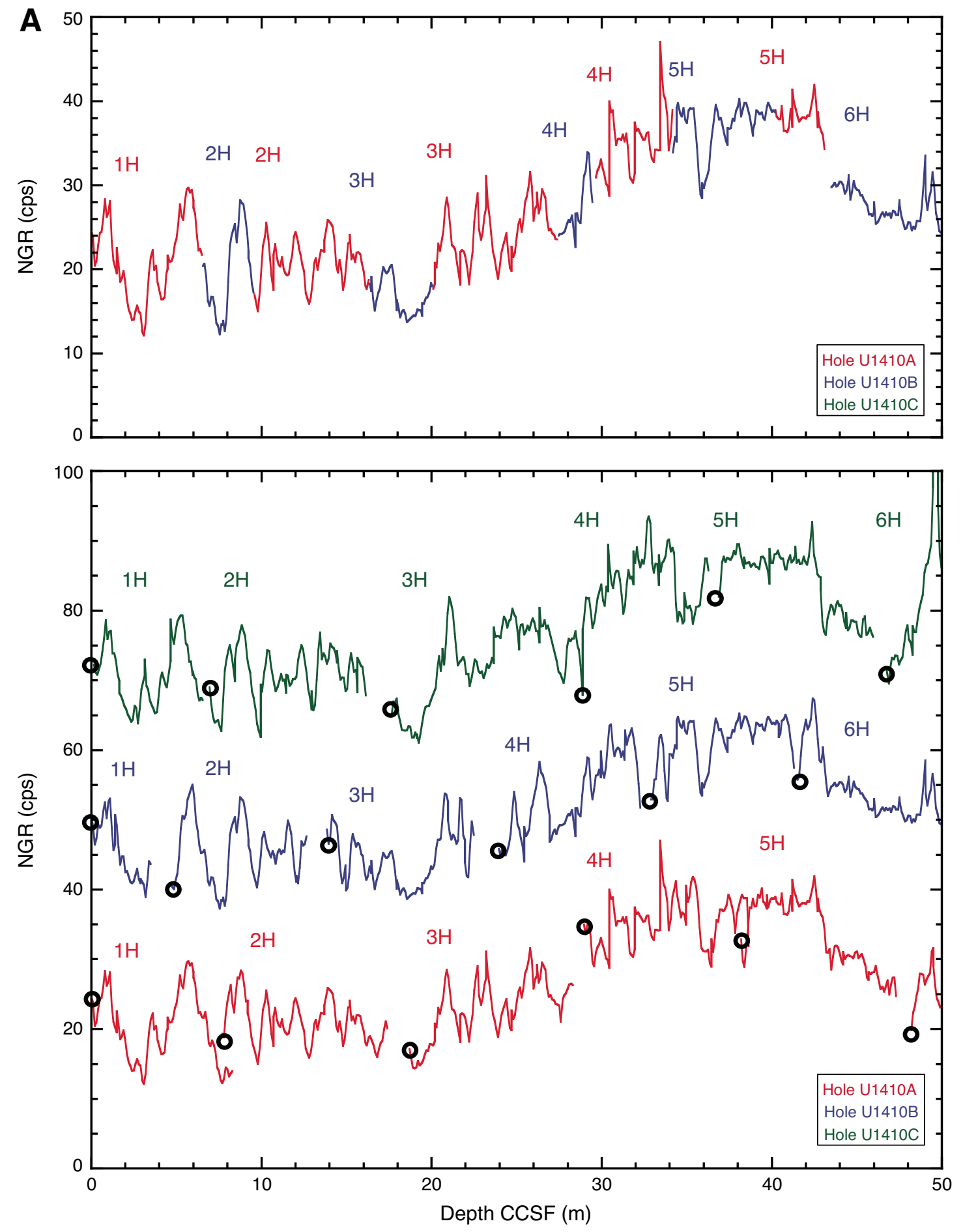
Figure F31 (continued). B. 50-100 m CCSF. (Continued on next page.)
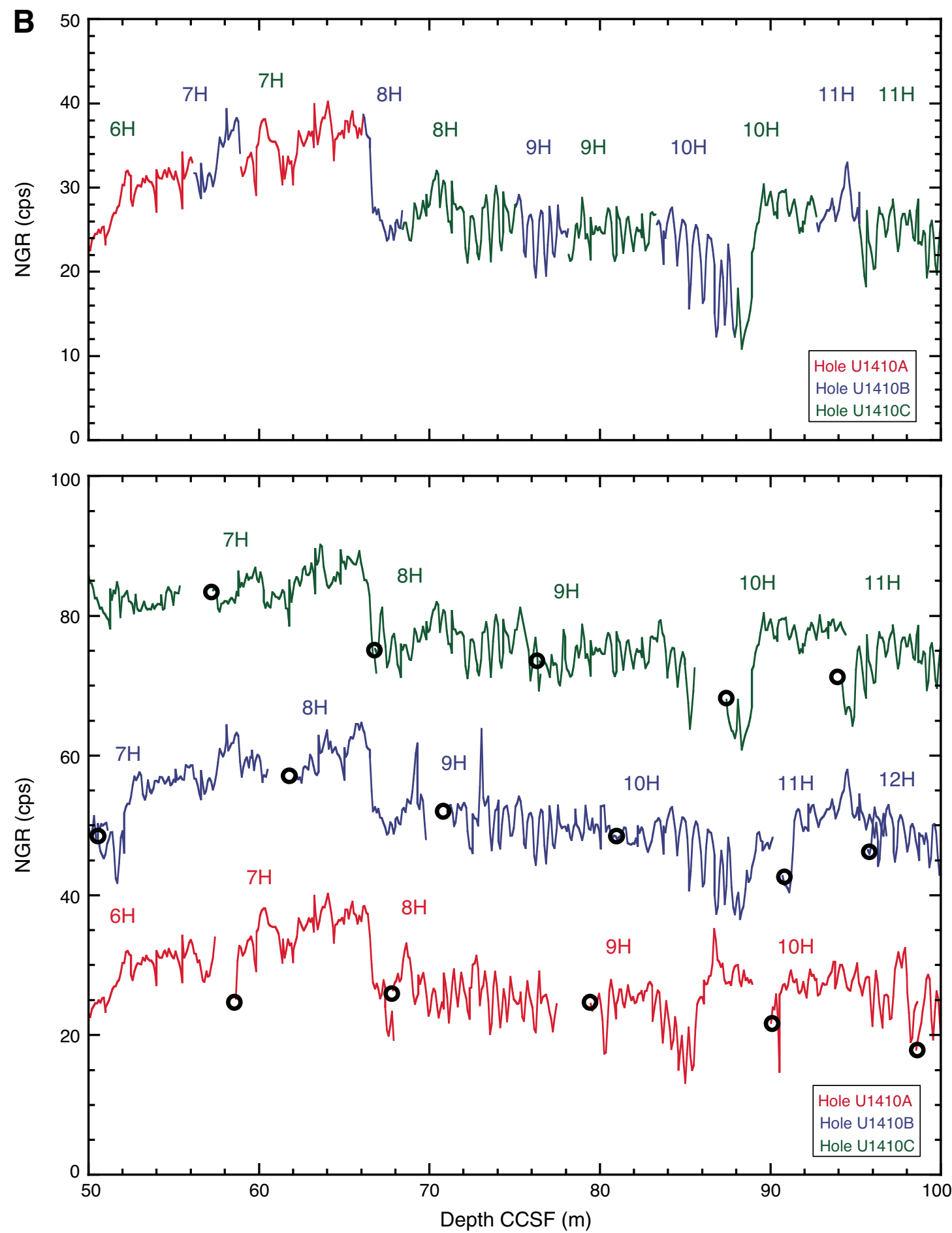
Figure F31 (continued). C. 100-150 m CCSF. (Continued on next page.)
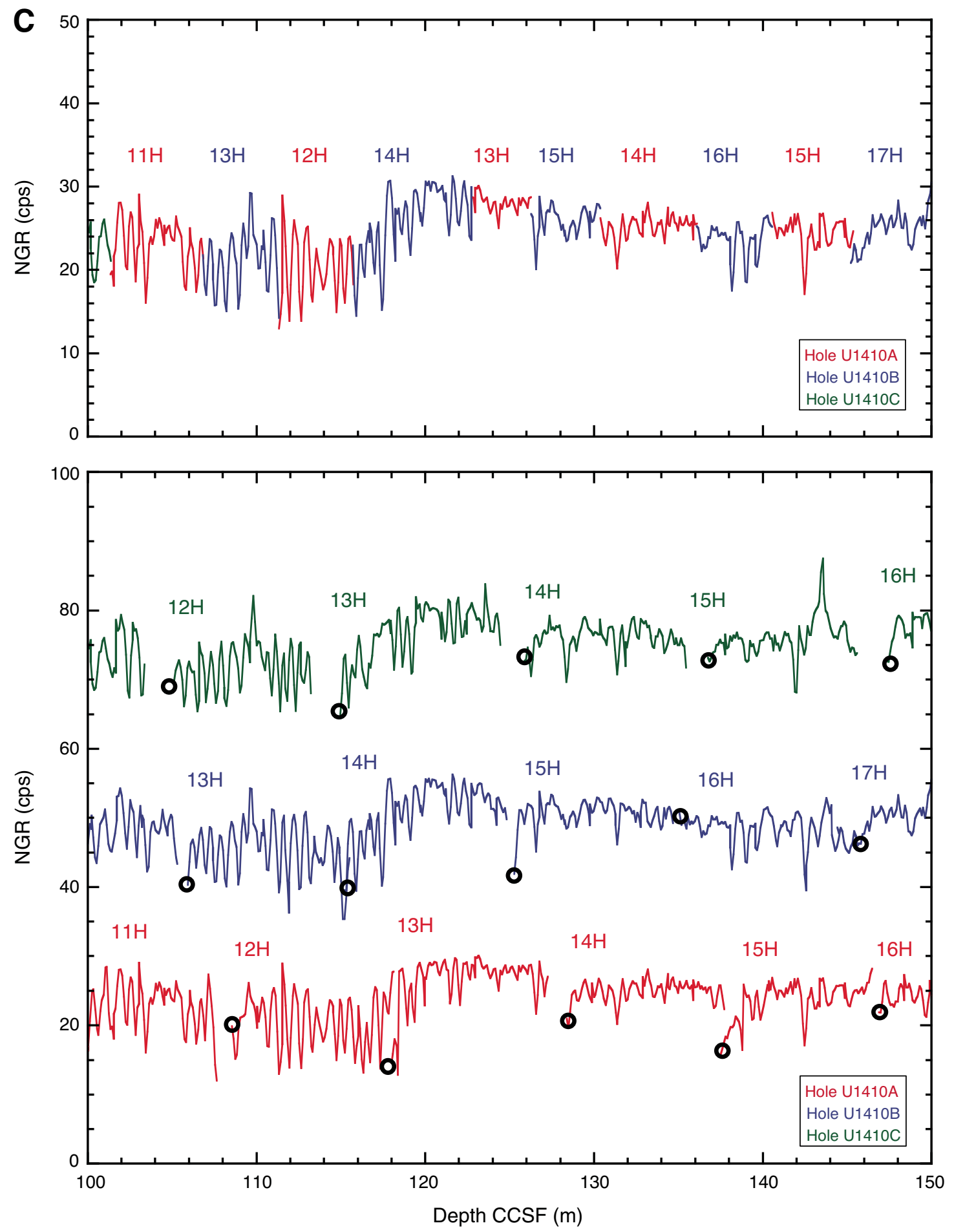
Figure F31 (continued). D. 150-200 m CCSF. (Continued on next page.)
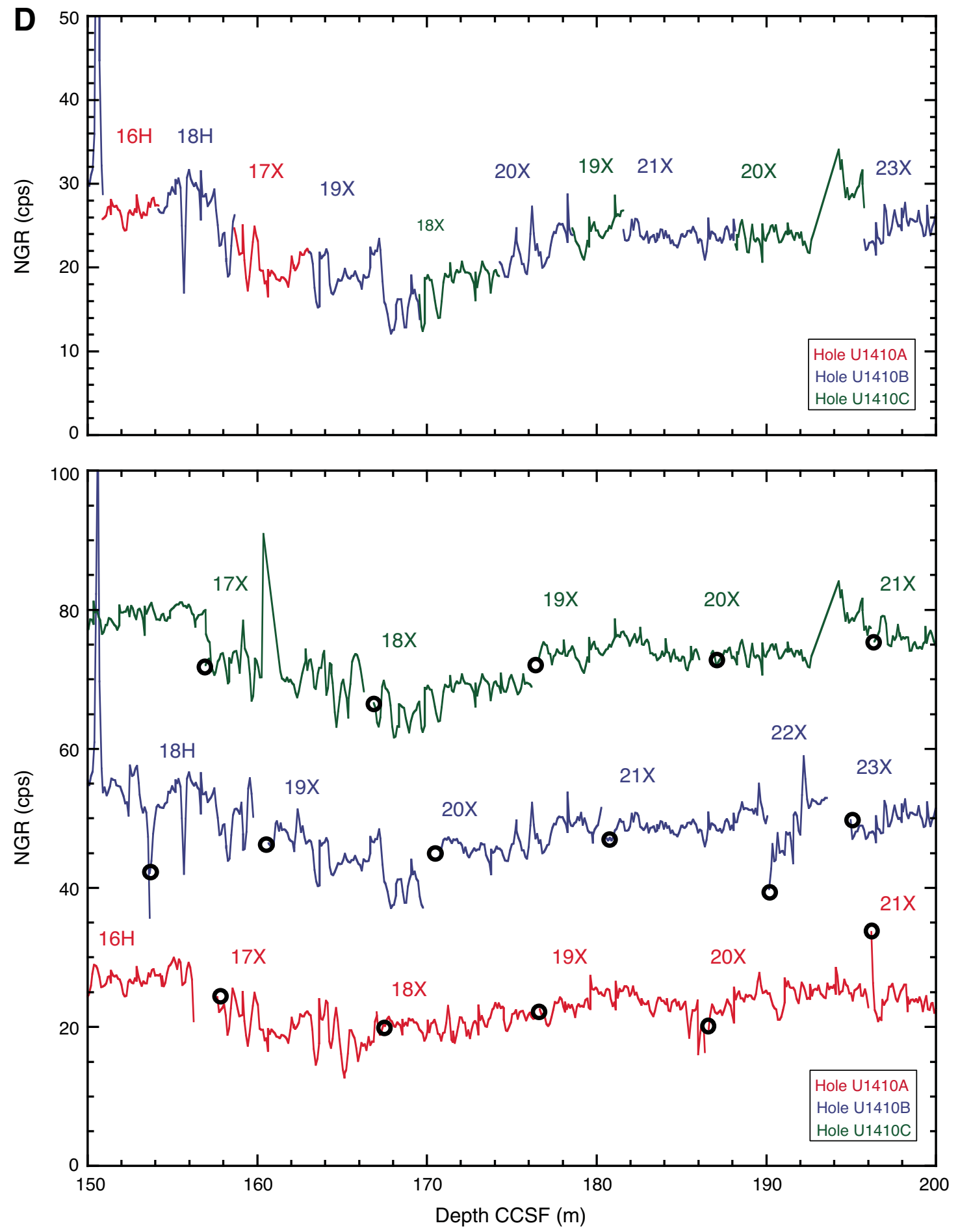
Figure F31 (continued). E. 200-250 m CCSF. (Continued on next page.)
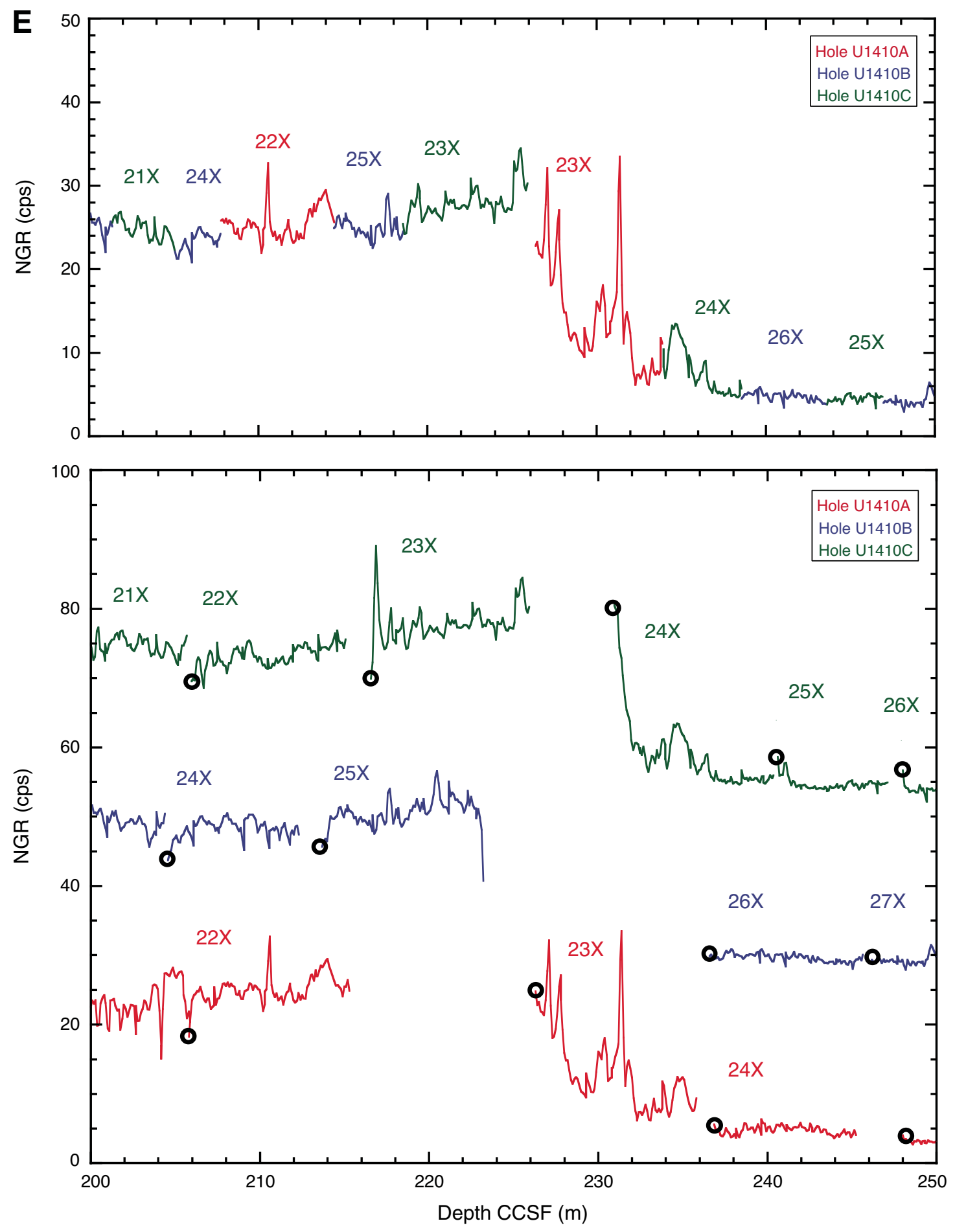
Figure F31 (continued). F. 250-280 m CCSF.
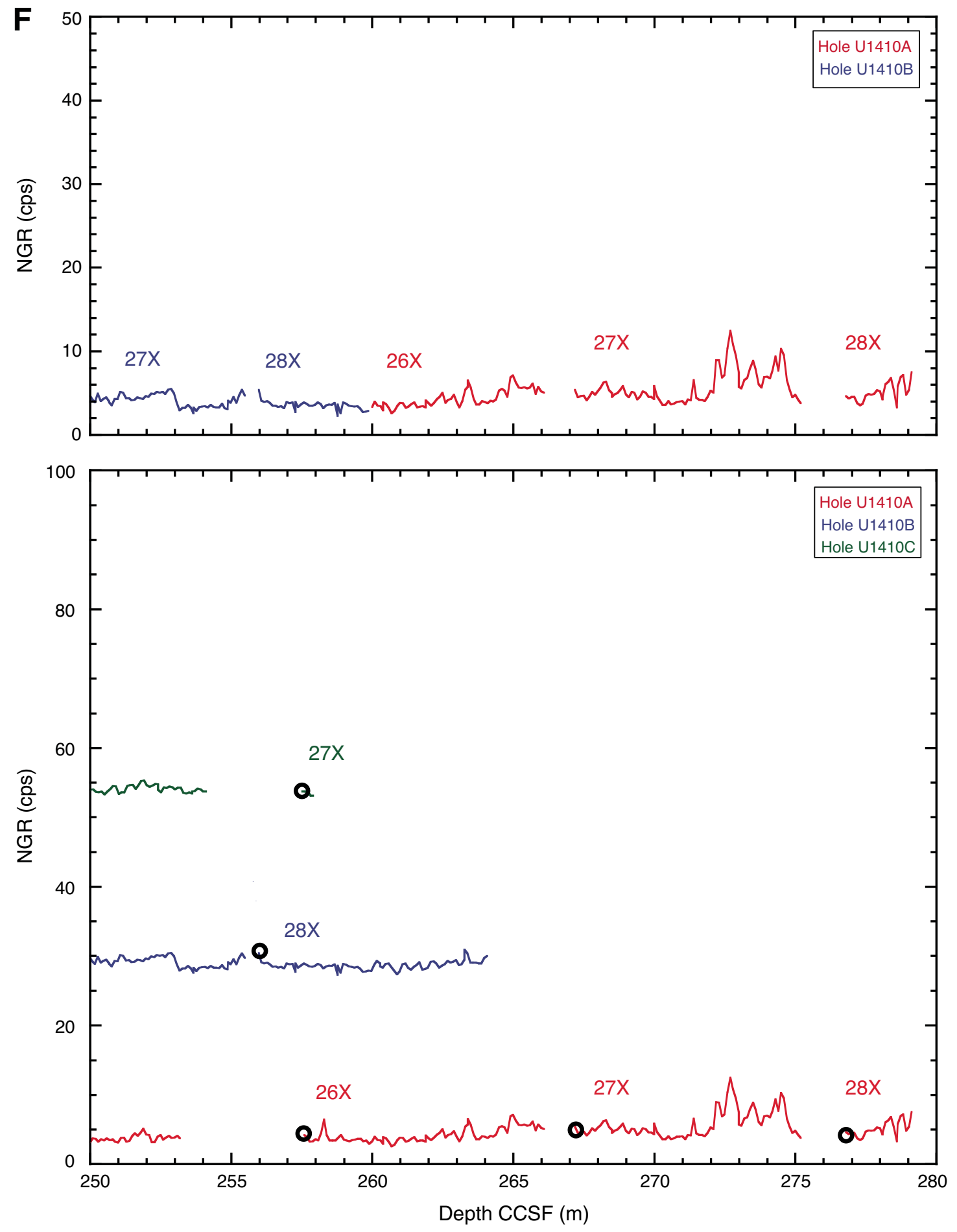
Figure F32. Plot of mbsf depth vs. CCSF depth, Site U1410. The growth factor is equal to the slope of the regression line.

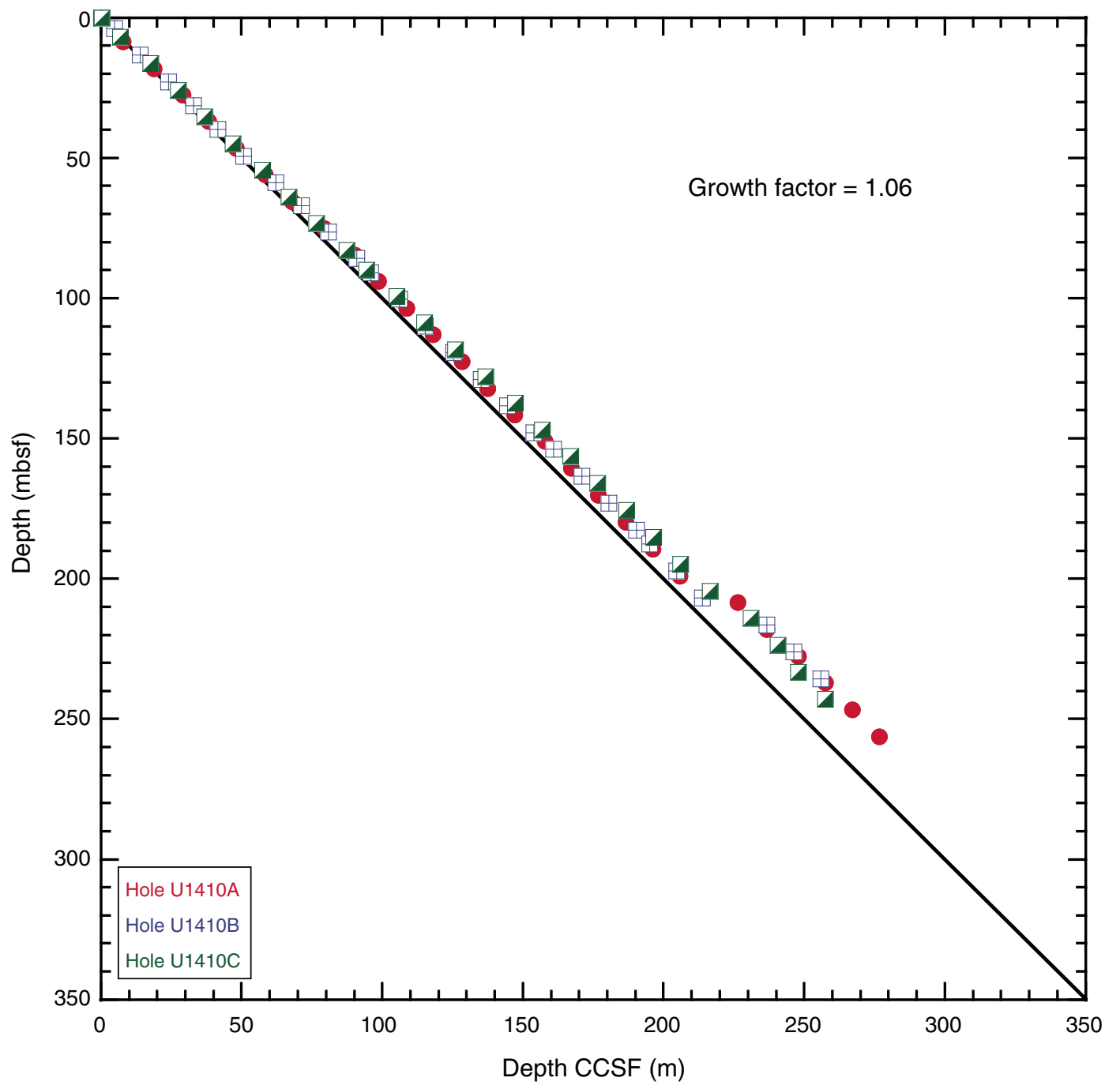


Table T1. Coring summary, Site U1410. (Continued on next page.)

\begin{tabular}{|c|c|c|c|c|c|c|c|c|c|c|}
\hline \multirow[b]{2}{*}{ Core } & \multirow[b]{2}{*}{$\begin{array}{c}\text { Date } \\
(2012)\end{array}$} & \multirow[b]{2}{*}{$\begin{array}{l}\text { Time } \\
\text { UTC } \\
\text { (h) }\end{array}$} & \multicolumn{2}{|c|}{ Depth DSF (m) } & \multirow[b]{2}{*}{$\begin{array}{l}\text { Interval } \\
\text { cored } \\
(\mathrm{m})\end{array}$} & \multirow[b]{2}{*}{$\begin{array}{l}\text { Curated } \\
\text { length } \\
(\mathrm{m})\end{array}$} & \multicolumn{2}{|c|}{ Depth CSF-A (m) } & \multirow[b]{2}{*}{$\begin{array}{c}\text { Recovery } \\
\text { (\%) }\end{array}$} & \multirow[b]{2}{*}{$\begin{array}{l}\text { Section } \\
(N)\end{array}$} \\
\hline & & & $\begin{array}{l}\text { Top of } \\
\text { cored } \\
\text { interval }\end{array}$ & $\begin{array}{l}\text { Bottom } \\
\text { of cored } \\
\text { interval }\end{array}$ & & & $\begin{array}{c}\text { Top of } \\
\text { core }\end{array}$ & $\begin{array}{c}\text { Bottom of } \\
\text { core }\end{array}$ & & \\
\hline \multicolumn{11}{|c|}{ 342-U1410A- } \\
\hline $1 \mathrm{H}$ & $21 \mathrm{Jul}$ & 0010 & 0.0 & 8.5 & 8.5 & 8.53 & 0.00 & 8.53 & 100 & 7 \\
\hline $2 \mathrm{H}$ & $21 \mathrm{Jul}$ & 0120 & 8.5 & 18.0 & 9.5 & 9.91 & 8.50 & 18.41 & 104 & 8 \\
\hline $3 \mathrm{H}$ & $21 \mathrm{Jul}$ & 0205 & 18.0 & 27.5 & 9.5 & 9.91 & 18.00 & 27.91 & 104 & 8 \\
\hline $4 \mathrm{H}$ & $21 \mathrm{Jul}$ & 0255 & 27.5 & 37.0 & 9.5 & 10.07 & 27.50 & 37.57 & 106 & 8 \\
\hline $5 \mathrm{H}$ & $21 \mathrm{Jul}$ & 0345 & 37.0 & 46.5 & 9.5 & 9.50 & 37.00 & 46.50 & 100 & 8 \\
\hline $6 \mathrm{H}$ & $21 \mathrm{Jul}$ & 0440 & 46.5 & 56.0 & 9.5 & 9.74 & 46.50 & 56.24 & 103 & 8 \\
\hline $7 \mathrm{H}$ & $21 \mathrm{Jul}$ & 0525 & 56.0 & 65.5 & 9.5 & 9.71 & 56.00 & 65.71 & 102 & 8 \\
\hline $8 \mathrm{H}$ & $21 \mathrm{Jul}$ & 0625 & 65.5 & 75.0 & 9.5 & 9.94 & 65.50 & 75.44 & 105 & 8 \\
\hline $9 \mathrm{H}$ & $21 \mathrm{Jul}$ & 0725 & 75.0 & 84.5 & 9.5 & 9.61 & 75.00 & 84.61 & 101 & 8 \\
\hline $10 \mathrm{H}$ & $21 \mathrm{Jul}$ & 0815 & 84.5 & 94.0 & 9.5 & 8.71 & 84.50 & 93.21 & 92 & 8 \\
\hline $11 \mathrm{H}$ & $21 \mathrm{Jul}$ & 0945 & 94.0 & 103.5 & 9.5 & 9.21 & 94.00 & 103.21 & 97 & 8 \\
\hline $12 \mathrm{H}$ & $21 \mathrm{Jul}$ & 1035 & 103.5 & 113.0 & 9.5 & 9.92 & 103.50 & 113.42 & 104 & 8 \\
\hline $13 \mathrm{H}$ & $21 \mathrm{Jul}$ & 1145 & 113.0 & 122.5 & 9.5 & 9.62 & 113.00 & 122.62 & 101 & 8 \\
\hline $14 \mathrm{H}$ & $21 \mathrm{Jul}$ & 1235 & 122.5 & 132.0 & 9.5 & 9.54 & 122.50 & 132.04 & 100 & 7 \\
\hline $15 \mathrm{H}$ & $21 \mathrm{Jul}$ & 1340 & 132.0 & 141.5 & 9.5 & 9.52 & 132.00 & 141.52 & 100 & 7 \\
\hline $16 \mathrm{H}$ & $21 \mathrm{Jul}$ & 1500 & 141.5 & 151.0 & 9.5 & 9.60 & 141.50 & 151.10 & 101 & 7 \\
\hline $17 X$ & $21 \mathrm{Jul}$ & 1635 & 151.0 & 160.6 & 9.6 & 9.84 & 151.00 & 160.84 & 103 & 8 \\
\hline $18 x$ & $21 \mathrm{Jul}$ & 1740 & 160.6 & 170.2 & 9.6 & 9.75 & 160.60 & 170.35 & 102 & 8 \\
\hline $19 x$ & $21 \mathrm{Jul}$ & 1845 & 170.2 & 179.8 & 9.6 & 9.81 & 170.20 & 180.01 & 102 & 8 \\
\hline $20 x$ & $21 \mathrm{Jul}$ & 2020 & 179.8 & 189.4 & 9.6 & 9.84 & 179.80 & 189.64 & 103 & 8 \\
\hline $21 x$ & $21 \mathrm{Jul}$ & 2125 & 189.4 & 199.0 & 9.6 & 9.75 & 189.40 & 199.15 & 102 & 8 \\
\hline $22 x$ & $21 \mathrm{Jul}$ & 2235 & 199.0 & 208.5 & 9.5 & 9.95 & 199.00 & 208.95 & 105 & 8 \\
\hline $23 x$ & $21 \mathrm{Jul}$ & 2330 & 208.5 & 218.0 & 9.5 & 9.95 & 208.50 & 218.45 & 105 & 8 \\
\hline $24 X$ & $22 \mathrm{Jul}$ & 0025 & 218.0 & 227.5 & 9.5 & 9.08 & 218.00 & 227.08 & 96 & 7 \\
\hline $25 x$ & $22 \mathrm{Jul}$ & 0115 & 227.5 & 237.1 & 9.6 & 5.73 & 227.50 & 233.23 & 60 & 5 \\
\hline $26 X$ & $22 \mathrm{Jul}$ & 0215 & 237.1 & 246.7 & 9.6 & 9.03 & 237.10 & 246.13 & 94 & 7 \\
\hline $27 X$ & $22 \mathrm{Jul}$ & 0355 & 246.7 & 256.3 & 9.6 & 8.50 & 246.70 & 255.20 & 89 & 7 \\
\hline \multirow[t]{2}{*}{$28 x$} & $22 \mathrm{Jul}$ & 0555 & 256.3 & 259.8 & 3.5 & 2.61 & 256.30 & 258.91 & 75 & 3 \\
\hline & & & & Totals & 259.8 & 256.88 & & & 98 & 209 \\
\hline
\end{tabular}

342-U1410B-

\begin{tabular}{|c|c|c|c|c|c|c|c|c|c|c|}
\hline $1 \mathrm{H}$ & $22 \mathrm{Jul}$ & 0940 & 0.0 & 3.8 & 3.8 & 3.82 & 0.00 & 3.82 & 101 & 4 \\
\hline $2 \mathrm{H}$ & $22 \mathrm{Jul}$ & 1150 & 3.8 & 13.3 & 9.5 & 8.08 & 3.80 & 11.88 & 85 & 7 \\
\hline $3 \mathrm{H}$ & $22 \mathrm{Jul}$ & 1250 & 13.3 & 22.8 & 9.5 & 8.91 & 13.30 & 22.21 & 94 & 8 \\
\hline $4 \mathrm{H}$ & $22 \mathrm{Jul}$ & 1440 & 22.8 & 31.3 & 8.5 & 8.52 & 22.80 & 31.32 & 100 & 7 \\
\hline $5 \mathrm{H}$ & $22 \mathrm{Jul}$ & 1610 & 31.3 & 39.7 & 8.4 & 8.46 & 31.30 & 39.76 & 101 & 7 \\
\hline $6 \mathrm{H}$ & $22 \mathrm{Jul}$ & 1700 & 39.7 & 49.2 & 9.5 & 10.05 & 39.70 & 49.75 & 106 & 8 \\
\hline $7 \mathrm{H}$ & $22 \mathrm{Jul}$ & 1755 & 49.2 & 58.7 & 9.5 & 10.02 & 49.20 & 59.22 & 105 & 8 \\
\hline $8 \mathrm{H}$ & $22 \mathrm{Jul}$ & 1850 & 58.7 & 66.8 & 8.1 & 8.14 & 58.70 & 66.84 & 100 & 7 \\
\hline $9 \mathrm{H}$ & $22 \mathrm{Jul}$ & 1945 & 66.8 & 76.3 & 9.5 & 9.97 & 66.80 & 76.77 & 105 & 8 \\
\hline $10 \mathrm{H}$ & $22 \mathrm{Jul}$ & 2120 & 76.3 & 85.8 & 9.5 & 9.49 & 76.30 & 85.79 & 100 & 7 \\
\hline $11 \mathrm{H}$ & $22 \mathrm{Jul}$ & 2215 & 85.8 & 90.8 & 5.0 & 6.24 & 85.80 & 92.04 & 125 & 6 \\
\hline $12 \mathrm{H}$ & $22 \mathrm{Jul}$ & 2310 & 90.8 & 100.3 & 9.5 & 9.81 & 90.80 & 100.61 & 103 & 8 \\
\hline $13 \mathrm{H}$ & $23 \mathrm{Jul}$ & 0010 & 100.3 & 109.8 & 9.5 & 9.78 & 100.30 & 110.08 & 103 & 8 \\
\hline $14 \mathrm{H}$ & $23 \mathrm{Jul}$ & 0100 & 109.8 & 119.3 & 9.5 & 9.75 & 109.80 & 119.55 & 103 & 8 \\
\hline $15 \mathrm{H}$ & $23 \mathrm{Jul}$ & 0150 & 119.3 & 128.8 & 9.5 & 9.56 & 119.30 & 128.86 & 101 & 7 \\
\hline $16 \mathrm{H}$ & $23 \mathrm{Jul}$ & 0245 & 128.8 & 138.3 & 9.5 & 10.02 & 128.80 & 138.82 & 105 & 8 \\
\hline $17 \mathrm{H}$ & $23 \mathrm{Jul}$ & 0350 & 138.3 & 147.8 & 9.5 & 9.32 & 138.30 & 147.62 & 98 & 8 \\
\hline $18 \mathrm{H}$ & $23 \mathrm{Jul}$ & 0510 & 147.8 & 153.8 & 6.0 & 6.40 & 147.80 & 154.20 & 107 & 6 \\
\hline $19 x$ & $23 \mathrm{Jul}$ & 0720 & 153.8 & 163.4 & 9.6 & 9.55 & 153.80 & 163.35 & 99 & 8 \\
\hline $20 x$ & $23 \mathrm{Jul}$ & 0825 & 163.4 & 173.0 & 9.6 & 9.83 & 163.40 & 173.23 & 102 & 8 \\
\hline $21 x$ & $23 \mathrm{Jul}$ & 0935 & 173.0 & 182.6 & 9.6 & 9.82 & 173.00 & 182.82 & 102 & 8 \\
\hline $22 x$ & $23 \mathrm{Jul}$ & 1030 & 182.6 & 187.6 & 5.0 & 3.93 & 182.60 & 186.53 & 79 & 4 \\
\hline $23 x$ & $23 \mathrm{Jul}$ & 1205 & 187.6 & 197.2 & 9.6 & 9.89 & 187.60 & 197.49 & 103 & 8 \\
\hline $24 X$ & $23 \mathrm{Jul}$ & 1315 & 197.2 & 206.8 & 9.6 & 8.27 & 197.20 & 205.47 & 86 & 7 \\
\hline $25 X$ & $23 \mathrm{Jul}$ & 1430 & 206.8 & 216.4 & 9.6 & 9.53 & 206.80 & 216.33 & 99 & 8 \\
\hline $26 x$ & $23 \mathrm{Jul}$ & 1520 & 216.4 & 226.0 & 9.6 & 9.38 & 216.40 & 225.78 & 98 & 8 \\
\hline $27 x$ & $23 \mathrm{Jul}$ & 1605 & 226.0 & 235.6 & 9.6 & 9.65 & 226.00 & 235.65 & 101 & 8 \\
\hline \multirow[t]{2}{*}{$28 \mathrm{X}$} & $23 \mathrm{Jul}$ & 1720 & 235.6 & 245.2 & 9.6 & 8.65 & 235.60 & 244.25 & 90 & 7 \\
\hline & & & & Total & 5.2 & 244.84 & & & 100 & 204 \\
\hline
\end{tabular}

342-U1410C-

$\begin{array}{rrrrrrrrrrr}1 \mathrm{H} & 23 \mathrm{Jul} & 2010 & 0.0 & 6.8 & 6.8 & 6.82 & 0.00 & 6.82 & 100 & 6 \\ 2 \mathrm{H} & 23 \mathrm{Jul} & 2230 & 6.8 & 16.3 & 9.5 & 9.39 & 6.80 & 16.19 & 99 & 8 \\ 3 \mathrm{H} & 23 \mathrm{Jul} & 2325 & 16.3 & 25.8 & 9.5 & 9.48 & 16.30 & 25.78 & 100 & 8 \\ 4 \mathrm{H} & 24 \mathrm{Jul} & 0055 & 25.8 & 35.3 & 9.5 & 9.31 & 25.80 & 35.11 & 98 & 7 \\ 5 \mathrm{H} & 24 \mathrm{Jul} & 0140 & 35.3 & 44.8 & 9.5 & 9.31 & 35.30 & 44.61 & 98 & 8\end{array}$


Table T1 (continued).

\begin{tabular}{|c|c|c|c|c|c|c|c|c|c|c|}
\hline \multirow[b]{2}{*}{ Core } & \multirow[b]{2}{*}{$\begin{array}{c}\text { Date } \\
\text { (2012) }\end{array}$} & \multirow[b]{2}{*}{$\begin{array}{c}\text { Time } \\
\text { UTC } \\
\text { (h) }\end{array}$} & \multicolumn{2}{|c|}{ Depth DSF $(\mathrm{m})$} & \multirow[b]{2}{*}{$\begin{array}{l}\text { Interval } \\
\text { cored } \\
(\mathrm{m})\end{array}$} & \multirow[b]{2}{*}{$\begin{array}{l}\text { Curated } \\
\text { length } \\
\text { (m) }\end{array}$} & \multicolumn{2}{|c|}{ Depth CSF-A (m) } & \multirow[b]{2}{*}{$\begin{array}{l}\text { Recovery } \\
\text { (\%) }\end{array}$} & \multirow[b]{2}{*}{$\begin{array}{l}\text { Sections } \\
(N)\end{array}$} \\
\hline & & & $\begin{array}{l}\text { Top of } \\
\text { cored } \\
\text { interval }\end{array}$ & $\begin{array}{l}\text { Bottom } \\
\text { of cored } \\
\text { interval }\end{array}$ & & & $\begin{array}{l}\text { Top of } \\
\text { core }\end{array}$ & $\begin{array}{l}\text { Bottom of } \\
\text { core }\end{array}$ & & \\
\hline $6 \mathrm{H}$ & $24 \mathrm{Jul}$ & 0230 & 44.8 & 54.3 & 9.5 & 8.96 & 44.80 & 53.76 & 94 & 7 \\
\hline $7 \mathrm{H}$ & $24 \mathrm{Jul}$ & 0400 & 54.3 & 63.8 & 9.5 & 9.78 & 54.30 & 64.08 & 103 & 8 \\
\hline $8 \mathrm{H}$ & $24 \mathrm{Jul}$ & 0455 & 63.8 & 73.3 & 9.5 & 10.09 & 63.80 & 73.89 & 106 & 8 \\
\hline $9 \mathrm{H}$ & $24 \mathrm{Jul}$ & 0540 & 73.3 & 82.8 & 9.5 & 9.27 & 73.30 & 82.57 & 98 & 8 \\
\hline $10 \mathrm{H}$ & $24 \mathrm{Jul}$ & 0630 & 82.8 & 89.8 & 7.0 & 7.31 & 82.80 & 90.11 & 104 & 6 \\
\hline $11 \mathrm{H}$ & $24 \mathrm{Jul}$ & 0725 & 89.8 & 99.3 & 9.5 & 9.59 & 89.80 & 99.39 & 101 & 8 \\
\hline $12 \mathrm{H}$ & $24 \mathrm{Jul}$ & 0855 & 99.3 & 108.8 & 9.5 & 8.54 & 99.30 & 107.84 & 90 & 7 \\
\hline $13 \mathrm{H}$ & $24 \mathrm{Jul}$ & 0950 & 108.8 & 118.3 & 9.5 & 9.61 & 108.80 & 118.41 & 101 & 7 \\
\hline $14 \mathrm{H}$ & $24 \mathrm{Jul}$ & 1040 & 118.3 & 127.8 & 9.5 & 9.93 & 118.30 & 128.23 & 105 & 8 \\
\hline $15 \mathrm{H}$ & $24 \mathrm{Jul}$ & 1130 & 127.8 & 137.3 & 9.5 & 9.08 & 127.80 & 136.88 & 96 & 7 \\
\hline $16 \mathrm{H}$ & $24 \mathrm{Jul}$ & 1310 & 137.3 & 146.8 & 9.5 & 10.09 & 137.30 & 147.39 & 106 & 8 \\
\hline $17 X$ & $24 \mathrm{Jul}$ & 1505 & 146.8 & 156.4 & 9.6 & 9.82 & 146.80 & 156.62 & 102 & 8 \\
\hline $18 X$ & $24 \mathrm{Jul}$ & 1605 & 156.4 & 166.0 & 9.6 & 9.77 & 156.40 & 166.17 & 102 & 8 \\
\hline $19 X$ & $24 \mathrm{Jul}$ & 1700 & 166.0 & 175.6 & 9.6 & 9.84 & 166.00 & 175.84 & 103 & 8 \\
\hline $20 x$ & $24 \mathrm{Jul}$ & 1805 & 175.6 & 185.2 & 9.6 & 9.84 & 175.60 & 185.44 & 103 & 8 \\
\hline $21 x$ & $24 \mathrm{Jul}$ & 1900 & 185.2 & 194.8 & 9.6 & 9.61 & 185.20 & 194.81 & 100 & 8 \\
\hline $22 x$ & $24 \mathrm{Jul}$ & 2015 & 194.8 & 204.4 & 9.6 & 9.52 & 194.80 & 204.32 & 99 & 8 \\
\hline $23 x$ & $24 \mathrm{Jul}$ & 2125 & 204.4 & 214.0 & 9.6 & 9.82 & 204.40 & 214.22 & 102 & 8 \\
\hline $24 X$ & $24 \mathrm{Jul}$ & 2225 & 214.0 & 223.6 & 9.6 & 9.75 & 214.00 & 223.75 & 102 & 8 \\
\hline $25 x$ & $24 \mathrm{Jul}$ & 2335 & 223.6 & 233.2 & 9.6 & 7.06 & 223.60 & 230.66 & 74 & 6 \\
\hline $26 x$ & $25 \mathrm{Jul}$ & 0035 & 233.2 & 242.8 & 9.6 & 6.63 & 233.20 & 239.83 & 69 & 6 \\
\hline \multirow{3}{*}{$27 X$} & $25 \mathrm{Jul}$ & 0125 & 242.8 & 243.8 & 1.0 & 0.59 & 242.80 & 243.39 & 59 & 2 \\
\hline & & & & Totals & 243.8 & 238.81 & & & 97 & 197 \\
\hline & & & \multicolumn{2}{|c|}{ Site U1410 totals: } & 748.8 & 740.23 & & & 98 & 1008 \\
\hline
\end{tabular}

DSF = drilling depth below seafloor, CSF-A = core depth below seafloor, method $\mathrm{A} . \mathrm{H}=$ advanced piston core, $\mathrm{X}=$ extended core barrel core .

Table T2. Lithostratigraphic unit intervals, Site U1410.

\begin{tabular}{|c|c|c|c|c|}
\hline \multirow{2}{*}{$\begin{array}{l}\text { Lith. } \\
\text { unit }\end{array}$} & \multicolumn{2}{|c|}{ Core, section, interval $(\mathrm{cm})$} & \multicolumn{2}{|c|}{ Depth (mbsf) } \\
\hline & Top & Bottom & Top & Bottom \\
\hline & 342-U1410A- & 342-U1410A- & & \\
\hline 1 & $1 \mathrm{H}-1,0$ & $4 \mathrm{H}-5,85$ & 0.00 & 34.35 \\
\hline II & $4 \mathrm{H}-5,85$ & $7 \mathrm{H}-7,62$ & 34.35 & 64.17 \\
\hline III & $7 \mathrm{H}-7,62$ & $23 X-1,150$ & 64.17 & 211.50 \\
\hline IVa & $23 X-2,0$ & $26 X-6,47$ & 211.50 & 245.07 \\
\hline \multirow[t]{2}{*}{$\mathrm{IVb}$} & $26 X-6,47$ & $28 \mathrm{X}-\mathrm{CC}, 58^{*}$ & 245.07 & 258.91 \\
\hline & 342-U1410B- & 342-U1410B- & & \\
\hline 1 & $1 \mathrm{H}-1,0$ & $5 \mathrm{H}-2,135$ & 0.00 & 34.15 \\
\hline II & $5 \mathrm{H}-2,135$ & $8 \mathrm{H}-4,7$ & 34.15 & 63.27 \\
\hline III & $8 \mathrm{H}-4,7$ & $25 \mathrm{X}-\mathrm{CC}, 35$ & 63.27 & 216.27 \\
\hline IVa & $26 X-1,0$ & $28 \mathrm{X}-\mathrm{CC}, 32^{*}$ & 225.49 & 244.25 \\
\hline \multirow[t]{2}{*}{$\mathrm{IVb}$} & Not drilled & & & \\
\hline & $342-U 1410 \mathrm{C}-$ & 342-U1410C- & & \\
\hline 1 & $1 \mathrm{H}-1,0$ & $4 \mathrm{H}-5,87$ & 0.00 & 32.67 \\
\hline II & $4 \mathrm{H}-5,87$ & $7 \mathrm{H}-7,24$ & 32.67 & 63.54 \\
\hline III & $7 \mathrm{H}-7,24$ & $23 \mathrm{X}-\mathrm{CC}, 37$ & 63.54 & 214.22 \\
\hline IVa & $24 X-1,0$ & $26 \mathrm{X}-\mathrm{CC}, 39$ & 214.00 & 239.83 \\
\hline $\mathrm{IVb}$ & $27 X-1,0$ & $27 \mathrm{X}-1,47^{*}$ & 242.80 & 243.27 \\
\hline
\end{tabular}

* $=$ end of hole. 
Table T3. Biostratigraphic and magnetostratigraphic datums, Hole U1410A.

\begin{tabular}{|c|c|c|c|c|c|c|c|}
\hline \multirow{2}{*}{$\begin{array}{l}\text { Datum tie } \\
\text { point }\end{array}$} & \multirow[b]{2}{*}{ Datum } & \multirow[b]{2}{*}{ Datum type } & \multirow{2}{*}{$\begin{array}{l}\text { Zone/ } \\
\text { Subzone }\end{array}$} & \multirow{2}{*}{$\begin{array}{l}\text { Age } \\
\text { (Ma) }\end{array}$} & \multicolumn{3}{|c|}{ Depth (mbsf) } \\
\hline & & & & & Top & Bottom & Midpoint \\
\hline & T Pseudoemiliania lacunosa & Calcareous nannofossil & NN20 & 0.44 & 6.56 & 8.48 & 7.52 \\
\hline & T Discoaster brouweri & Calcareous nannofossil & NN19 & 1.93 & 24.75 & 27.88 & 26.32 \\
\hline D03 & T Discoaster pentaradiatus & Calcareous nannofossil & NN17 & 2.39 & 31.51 & 31.51 & 31.51 \\
\hline D04 & T Discoaster hamatus & Calcareous nannofossil & NN10 & 9.53 & 34.50 & 37.57 & 36.04 \\
\hline D05 & B Discoaster hamatus & Calcareous nannofossil & NN9 & 10.55 & 41.00 & 44.00 & 42.50 \\
\hline D06 & Tc Sphenolithus belemnos & Calcareous nannofossil & NN4 & 17.95 & 44.00 & 46.45 & 45.23 \\
\hline D07 & B Sphenolithus belemnos & Calcareous nannofossil & & 19.03 & 46.45 & 50.00 & 48.23 \\
\hline D08 & B Discoaster druggii & Calcareous nannofossil & NN2 & 22.82 & 50.00 & 53.00 & 51.50 \\
\hline D09 & T Sphenolithus ciperoensis & Calcareous nannofossil & NN1 & 24.43 & 50.00 & 53.00 & 51.50 \\
\hline D10 & T Sphenolithus distentus & Calcareous nannofossil & NP25 & 26.84 & 56.20 & 59.55 & 57.88 \\
\hline \multirow[t]{21}{*}{ D11 } & T Reticulofenestra umbilicus (>14 $\mu \mathrm{m})$ & Calcareous nannofossil & NP23 & 32.02 & 64.17 & 64.25 & 64.21 \\
\hline & T Coccolithus formosus & Calcareous nannofossil & NP22 & 32.92 & 64.17 & 64.25 & 64.21 \\
\hline & T Chiasmolithus grandis & Calcareous nannofossil & & 37.98 & 64.17 & 64.25 & 64.21 \\
\hline & B Dictyococcites bisectus (>10 $\mu \mathrm{m})$ & Calcareous nannofossil & & 40.36 & 79.23 & 80.85 & 80.04 \\
\hline & T Sphenolithus furcatolithoides & Calcareous nannofossil & & & 82.95 & 83.71 & 83.33 \\
\hline & Tc Chiasmolithus solitus & Calcareous nannofossil & NP17 & 40.40 & 93.16 & 103.19 & 98.17 \\
\hline & B Reticulofenestra reticulata & Calcareous nannofossil & & 41.66 & 117.09 & 120.02 & 118.56 \\
\hline & T Nannotetrina spp. & Calcareous nannofossil & & 41.85 & 114.47 & 117.09 & 115.78 \\
\hline & B Reticulofenestra umbilicus (>14 $\mu \mathrm{m}$ ) & Calcareous nannofossil & & 41.94 & 134.07 & 137.09 & 135.58 \\
\hline & T Nannotetrina fulgens & Calcareous nannofossil & & 42.87 & 151.75 & 153.36 & 152.56 \\
\hline & T Chiasmolithus gigas & Calcareous nannofossil & NP15c & 44.12 & 153.36 & 153.37 & 153.37 \\
\hline & B Sphenolithus furcatolithoides & Calcareous nannofossil & & & 170.33 & 179.98 & 175.16 \\
\hline & B Chiasmolithus gigas & Calcareous nannofossil & NP15b & 45.49 & 190.74 & 193.75 & 192.25 \\
\hline & B Nannotetrina fulgens & Calcareous nannofossil & NP15a & 46.29 & 208.93 & 210.68 & 209.81 \\
\hline & B Nannotetrina cristata & Calcareous nannofossil & & 47.73 & 220.43 & 223.34 & 221.89 \\
\hline & B Blackites inflatus & Calcareous nannofossil & & 47.84 & 216.28 & 218.45 & 217.37 \\
\hline & T Discoaster lodoensis & Calcareous nannofossil & & 47.41 & 218.45 & 220.43 & 219.44 \\
\hline & B Discoaster sublodoensis (5 rayed) & Calcareous nannofossil & NP14 & 49.11 & 227.06 & 228.26 & 227.66 \\
\hline & T Tribrachiatus orthostylus & Calcareous nannofossil & NP13 & 50.50 & 242.45 & 244.00 & 243.23 \\
\hline & B Dictyococcites/Reticulofenestra & Calcareous nannofossil & & 50.50 & 244.00 & 245.16 & 244.58 \\
\hline & T Toweius spp. & Calcareous nannofossil & & 50.78 & 245.16 & 246.09 & 245.63 \\
\hline \multirow[t]{4}{*}{ D18 } & B Coccolithus crassus & Calcareous nannofossil & & 51.64 & 246.09 & 255.14 & 250.62 \\
\hline & B Discoaster lodoensis & Calcareous nannofossil & NP12 & 53.70 & 258.69 & 258.69 & 258.69 \\
\hline & B Dictyoprora mongolfieri & Radiolarian & RP11 & 47.98 & & 218.40 & 218.40 \\
\hline & B Lithochytris vespertilio & Radiolarian & RP10 & 48.57 & 227.10 & 233.20 & 230.15 \\
\hline \multirow[t]{2}{*}{ D17 } & B Lamptonium fabaeforme constrictum & Radiolarian & RP9 & 50.05 & 233.20 & 246.10 & 239.65 \\
\hline & T Buryella tetradica & Radiolarian & RP8 & 50.87 & 233.20 & 246.10 & 239.65 \\
\hline \multirow[t]{10}{*}{ D19 } & B Buryella clinata & Radiolarian & RP7 & 53.35 & 258.70 & & 258.70 \\
\hline & T Orbulinoides bekmanni & Planktonic foraminifer & E13/E12 & 40.03 & 69.61 & 71.11 & 70.36 \\
\hline & B Orbulinoides bekmanni & Planktonic foraminifer & E12/E11 & 40.43 & 84.56 & 85.46 & 85.01 \\
\hline & T Guembelitrioides nuttalli & Planktonic foraminifer & E11/E10 & 42.07 & 89.16 & 90.56 & 89.86 \\
\hline & T Morozovella lehneri & Planktonic foraminifer & $\begin{array}{c}\text { Just above } \\
\text { E10/E9 }\end{array}$ & 43.15 & 153.61 & 156.71 & 155.16 \\
\hline & B Globigerinatheka kugleri & Planktonic foraminifer & E9/E8 & 43.88 & 160.82 & 163.11 & 161.97 \\
\hline & B Guembelitrioides nuttalli & Planktonic foraminifer & $\mathrm{E} 8 / \mathrm{E} 7 \mathrm{~b}$ & 45.72 & 201.51 & 206.01 & 203.76 \\
\hline & B Turborotalia frontosa & Planktonic foraminifer & $E 7 b / E 7 a$ & 48.31 & 215.53 & 218.43 & 216.98 \\
\hline & B Acarinina cuniacamerata & Planktonic foraminifer & E7a/E6 & 50.20 & 239.75 & 244.08 & 241.92 \\
\hline & B Morozovella subbotinae & Planktonic foraminifer & E6/E5 & 50.67 & 252.83 & 255.14 & 253.99 \\
\hline \multirow[t]{5}{*}{ D01 } & C1n (Brunhes)/C1r.1r (Matuyama) & Chron boundary & & 0.78 & & & 11.50 \\
\hline & C1r.1r (Matuyama)/C1r.1n (Jaramillo) & Chron boundary & & 0.99 & & & 13.00 \\
\hline & C1r.1n (Jaramillo)/C1r.2r & Chron boundary & & 1.07 & & & 13.48 \\
\hline & C1r.2r/C1r.2n (Cobb Mountain) & Chron boundary & & 1.17 & & & 13.79 \\
\hline & C1r.2n (Cobb Mountain)/C1r.3r & Chron boundary & & 1.19 & & & 14.33 \\
\hline \multirow[t]{7}{*}{ D02 } & C1r.3r/C2n (Olduvai) & Chron boundary & & 1.78 & & & 17.13 \\
\hline & C2r.2r/C2An.1n (Gauss) & Chron boundary & & 2.58 & & & 32.95 \\
\hline & $\mathrm{C} 18 \mathrm{n} .1 \mathrm{n} / \mathrm{C} 18 \mathrm{n} .1 \mathrm{r}$ & Chron boundary & & 39.63 & & & 68.68 \\
\hline & $\mathrm{C} 18 \mathrm{n} \cdot 1 \mathrm{r} / \mathrm{C} 18 \mathrm{n} .2 \mathrm{n}$ & Chron boundary & & 39.70 & & & 71.25 \\
\hline & $\mathrm{C} 18 n .2 n / C 18 r$ & Chron boundary & & 40.14 & & & 80.15 \\
\hline & $\mathrm{C} 18 \mathrm{r} / \mathrm{C} 19 \mathrm{n}$ & Chron boundary & & 41.15 & & & 96.80 \\
\hline & $\mathrm{C} 19 n / C 19 r$ & Chron boundary & & 41.39 & & & 102.48 \\
\hline D13 & C19r/C2On & Chron boundary & & 42.30 & & & 121.55 \\
\hline D14 & $\mathrm{C} 20 \mathrm{n} / \mathrm{C} 20 \mathrm{r}$ & Chron boundary & & 43.43 & & & 151.27 \\
\hline D15 & $\mathrm{C} 20 \mathrm{r} / \mathrm{C} 21 \mathrm{n}$ & Chron boundary & & 45.72 & & & 197.39 \\
\hline D16 & $\mathrm{C} 21 \mathrm{n} / \mathrm{C} 21 \mathrm{r}$ & Chron boundary & & 47.35 & & & 218.06 \\
\hline
\end{tabular}

$\mathrm{B}=$ base, $\mathrm{T}=$ top, $\mathrm{Tc}=$ top common. 
Table T4. Calcareous nannofossil datums, Site U1410.

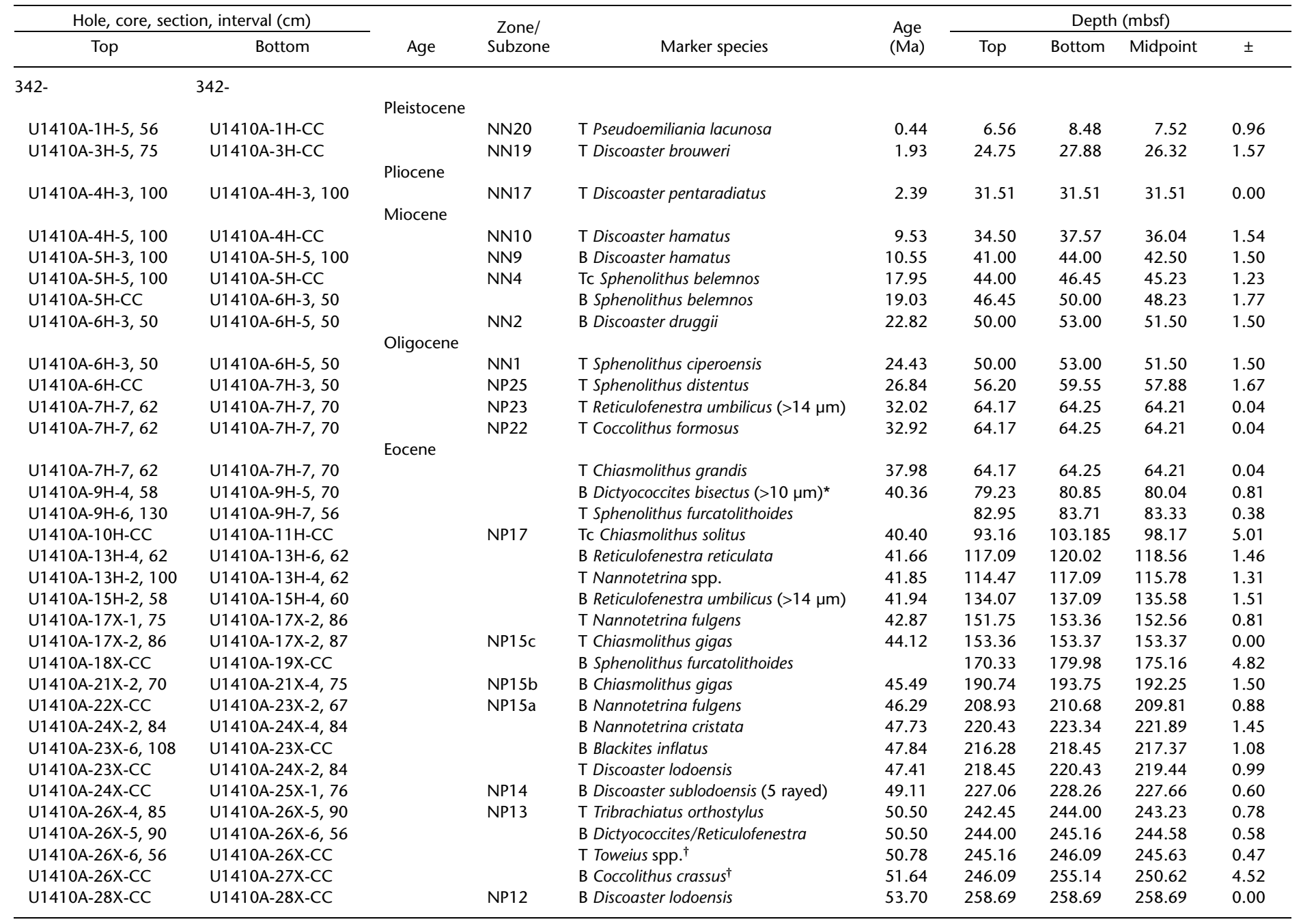

${ }^{*}=$ from Fornaciari et al. (2010) recalibrated to GTS2012. $\dagger=$ from Agnini et al. (2006) recalibrated to GTS2012. B = base, BC = base common, $T=$ top, Tc $=$ top common. 
Table T5. Stratigraphic distribution of selected nannofossils, Site U1410. This table available in an oversized format.

Table T6. Radiolarian datums, Site U1410.

\begin{tabular}{|c|c|c|c|c|c|c|c|c|c|}
\hline \multicolumn{2}{|c|}{ Core, section } & \multirow[b]{2}{*}{ Age } & \multirow[b]{2}{*}{ Zone } & \multirow[b]{2}{*}{ Marker species } & \multirow{2}{*}{$\begin{array}{l}\text { Age } \\
(\mathrm{Ma})\end{array}$} & \multicolumn{4}{|c|}{ Depth (mbsf) } \\
\hline Top & Bottom & & & & & Top & Bottom & Midpoint & \pm \\
\hline \multirow[t]{2}{*}{ 342-U1410A- } & 342-U1410A- & Eocene & & & & & & & \\
\hline & $23 X-C C$ & & RP11 & B Dictyoprora mongolfieri & 47.98 & 0.00 & 218.40 & 218.40 & \\
\hline $24 X-C C$ & $25 X-C C$ & & RP10 & B Lithochytris vespertilio & 48.57 & 227.10 & 233.20 & 230.15 & 3.05 \\
\hline $25 X-C C$ & $26 \mathrm{X}-\mathrm{CC}$ & & RP9 & B Lamptonium fabaeforme constrictum & 50.05 & 233.20 & 246.10 & 239.65 & 6.45 \\
\hline $25 X-C C$ & $26 \mathrm{X}-\mathrm{CC}$ & & & T Buryella tetradica & 50.87 & 233.20 & 246.10 & 239.65 & 6.45 \\
\hline $28 \mathrm{X}-\mathrm{CC}$ & & & RP8 & B Buryella clinata & 53.35 & 258.70 & & 258.70 & \\
\hline
\end{tabular}

$B=$ base,$T=$ top. 


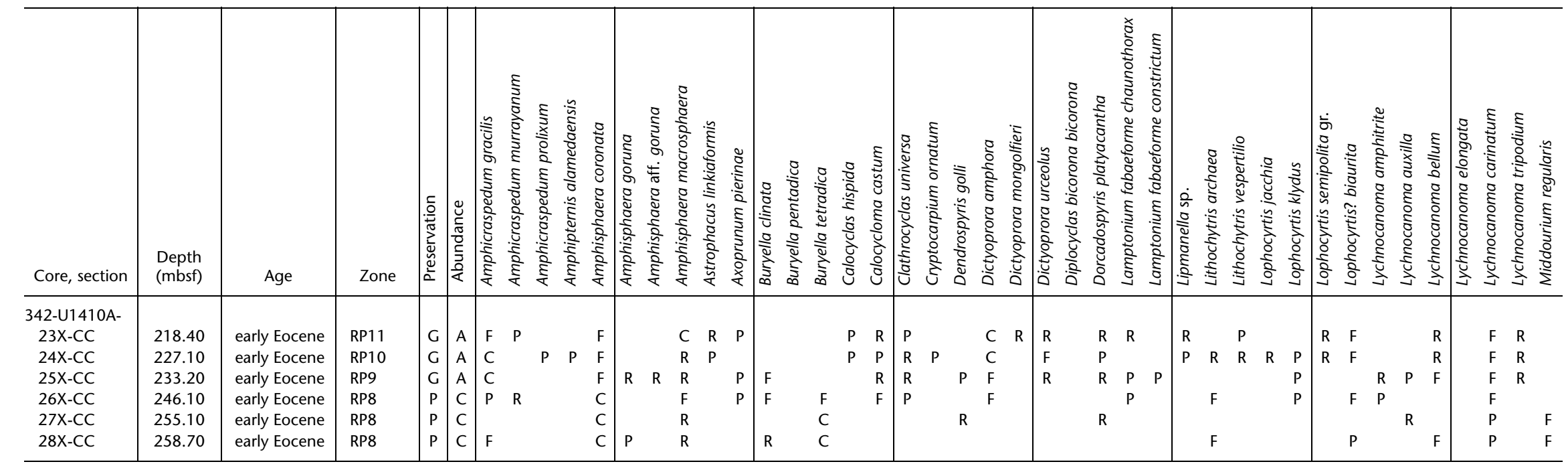

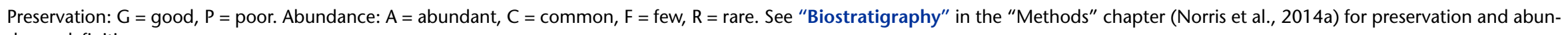

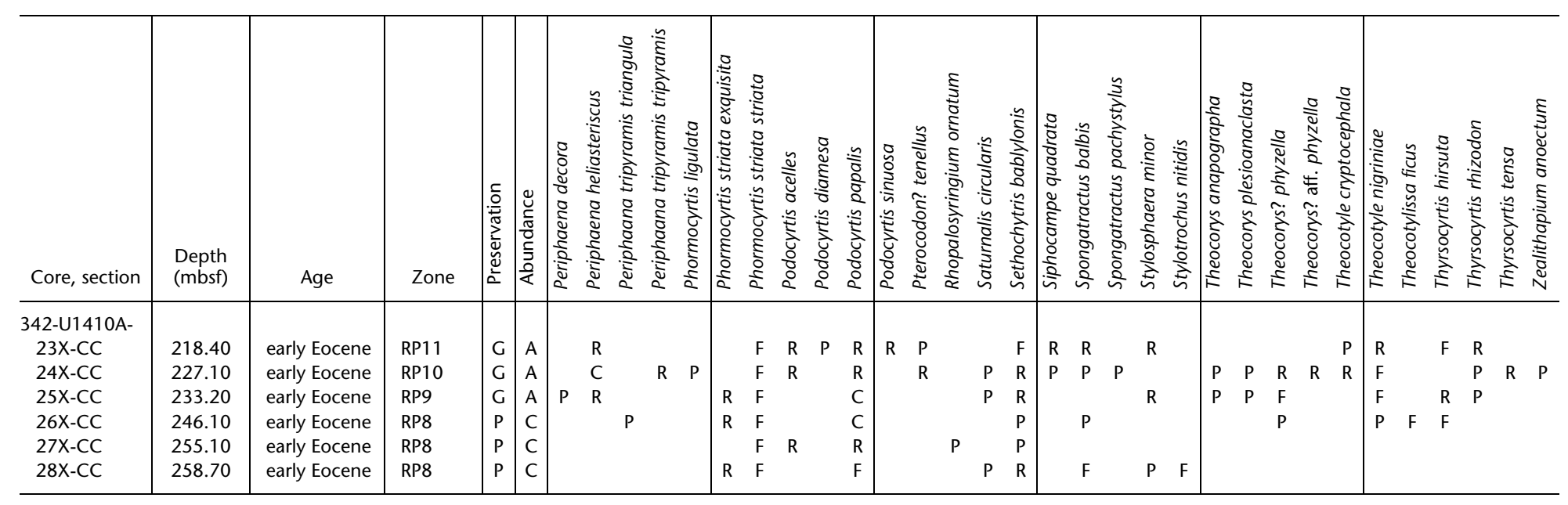


Table T8. Planktonic foraminifer datums, Site U1410.

\begin{tabular}{|c|c|c|c|c|c|c|c|c|c|}
\hline \multicolumn{2}{|c|}{ Core, section, interval $(\mathrm{cm})$} & \multirow{2}{*}{\multicolumn{2}{|c|}{$\begin{array}{l}\text { Zone/ } \\
\text { Subzone }\end{array}$}} & \multirow[b]{2}{*}{ Marker event } & \multirow{2}{*}{$\begin{array}{l}\text { Age } \\
(\mathrm{Ma})\end{array}$} & \multirow[b]{2}{*}{ Top } & \multicolumn{3}{|c|}{ Depth (mbsf) } \\
\hline Top & Bottom & & & & & & Bottom & Midpoint & \pm \\
\hline 342-U1410A- & 342-U1410A- & & & & & & & & \\
\hline $8 \mathrm{H}-3,110-112$ & $8 \mathrm{H}-4,110-112$ & middle Eocene & E13/E12 & T Orbulinoides bekmanni & 40.03 & 69.61 & 71.11 & 70.36 & 0.75 \\
\hline $9 \mathrm{H}-\mathrm{CC}$ & $10 \mathrm{H}-2,45-47$ & middle Eocene & E12/E11 & B Orbulinoides bekmanni & 40.43 & 84.56 & 85.46 & 85.01 & 0.45 \\
\hline $10 \mathrm{H}-5,90-92$ & $10 \mathrm{H}-6,90-92$ & middle Eocene & E11/E10 & T Guembelitrioides nuttalli & 42.07 & 89.16 & 90.56 & 89.86 & 0.70 \\
\hline $17 X-2,110-112$ & $17 X-4,120-122$ & middle Eocene & Just above E10/E9 & T Morozovella lehneri & 43.15 & 153.61 & 156.71 & 155.16 & 1.55 \\
\hline $17 X-C C$ & $18 X-2,100-102$ & middle Eocene & E9/E8 & B Globigerinatheka kugleri & 43.88 & 160.82 & 163.11 & 161.97 & 1.15 \\
\hline $22 X-2,100-102$ & $22 X-5,100-102$ & middle Eocene & E8/E7b & B Guembelitrioides nuttalli & 45.70 & 201.5 & 206.01 & 203.76 & 2.25 \\
\hline $23 X-5,102-104$ & $23 \mathrm{X}-\mathrm{CC}$ & early Eocene & E7b/E7a & B Turborotalia frontosa & 48.30 & 215.53 & 218.43 & 216.98 & 1.45 \\
\hline $26 \mathrm{X}-2,114-115$ & $26 X-5,97-98$ & early Eocene & E7a/E6 & B Acarinina cuniacamerata & 50.20 & 239.75 & 244.08 & 241.92 & 2.17 \\
\hline $27 X-5,12-13$ & $27 \mathrm{X}-\mathrm{CC}$ & early Eocene & E6/E5 & B Morozovella subbotinae & 50.67 & 252.83 & 255.14 & 253.99 & 1.15 \\
\hline
\end{tabular}

$\mathrm{T}=$ top, $\mathrm{B}=$ base.

Table T9. Planktonic foraminifer distribution, Site U1410. This table is available in an oversized format. 


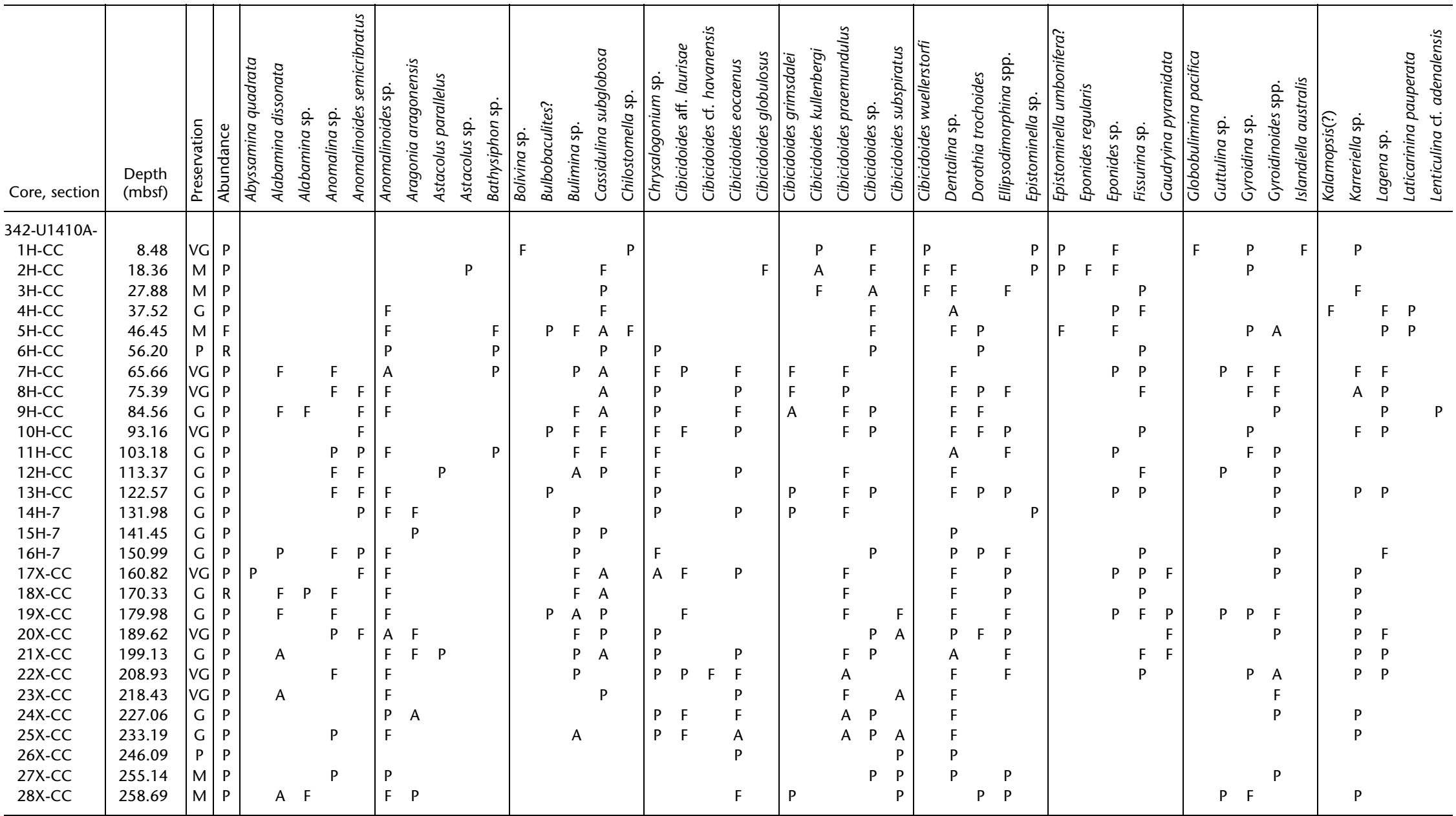

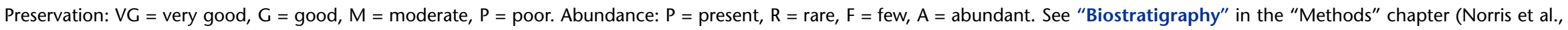
2014a) for preservation and abundance definitions. 


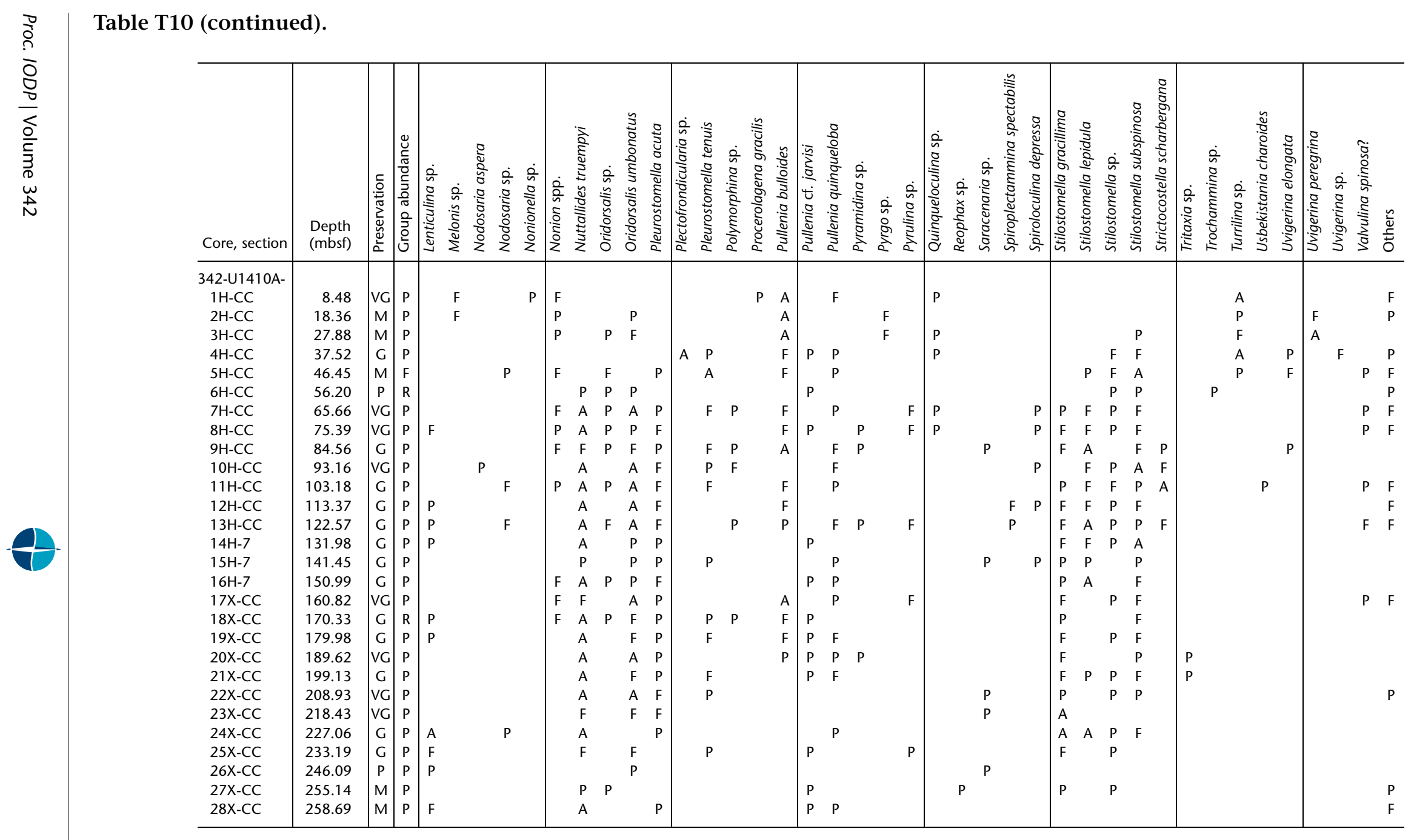


Table T11. Abundance and preservation of benthic foraminifers, Site U1410. (Continued on next page.)

\begin{tabular}{|c|c|c|c|}
\hline $\begin{array}{l}\text { Core, section, } \\
\text { interval }(\mathrm{cm})\end{array}$ & $\begin{array}{l}\text { Depth } \\
\text { (mbsf) }\end{array}$ & 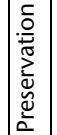 & 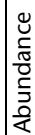 \\
\hline 342-U1410A- & & & \\
\hline $4 \mathrm{H}-1 \mathrm{~W}, 100-102$ & 28.51 & $G$ & $\mathrm{~F}$ \\
\hline $4 \mathrm{H}-2 \mathrm{~W}, 100-102$ & 30.01 & $M$ & $\mathrm{~F}$ \\
\hline $4 \mathrm{H}-3 \mathrm{~W}, 100-102$ & 31.51 & $G$ & \\
\hline $4 \mathrm{H}-4 \mathrm{~W}, 100-102$ & 33.01 & $M$ & \\
\hline $4 \mathrm{H}-5 \mathrm{~W}, 100-102$ & 34.51 & $\mathrm{P}$ & $\mathrm{F}$ \\
\hline $4 \mathrm{H}-6 \mathrm{~W}, 100-102$ & 36.01 & $G$ & P \\
\hline $5 \mathrm{H}-1 \mathrm{~W}, 100-102$ & 38.01 & $M$ & \\
\hline $5 \mathrm{H}-2 \mathrm{~W}, 100-102$ & 39.51 & $G$ & \\
\hline $5 \mathrm{H}-3 \mathrm{~W}, 100-102$ & 41.01 & $M$ & \\
\hline $5 \mathrm{H}-4 \mathrm{~W}, 100-102$ & 42.51 & & B \\
\hline $5 \mathrm{H}-5 \mathrm{~W}, 100-102$ & 44.01 & & \\
\hline $5 \mathrm{H}-6 \mathrm{~W}, 90-92$ & 45.41 & $M$ & \\
\hline $6 \mathrm{H}-2 \mathrm{~W}, 100-102$ & 49.01 & $P$ & \\
\hline $6 \mathrm{H}-4 \mathrm{~W}, 100-102$ & 52.01 & $\mathrm{P}$ & D \\
\hline $6 \mathrm{H}-6 \mathrm{~W}, 100-102$ & 55.01 & $\mathrm{P}$ & D \\
\hline 7H-2W, 100-102 & 58.53 & $\mathrm{P}$ & D \\
\hline 7H-5W, 100-102 & 61.90 & $M$ & \\
\hline $7 \mathrm{H}-7 \mathrm{~W}, 28-30$ & 63.84 & & \\
\hline 7H-7W, 100-102 & 64.56 & $G$ & 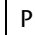 \\
\hline $8 \mathrm{H}-1 \mathrm{~W}, 110-112$ & 66.61 & $G$ & 8 \\
\hline $8 \mathrm{H}-2 \mathrm{~W}, 110-112$ & 68.11 & VG & D \\
\hline $8 \mathrm{H}-3 \mathrm{~W}, 110-112$ & 69.61 & $G$ & $\mathrm{P}$ \\
\hline $8 \mathrm{H}-4 \mathrm{~W}, 110-112$ & 71.11 & VG & $P$ \\
\hline $8 \mathrm{H}-5 \mathrm{~W}, 110-112$ & 72.61 & $G$ & D \\
\hline $8 \mathrm{H}-6 \mathrm{~W}, 110-112$ & 74.11 & $G$ & 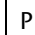 \\
\hline $9 \mathrm{H}-2 \mathrm{~W}, 110-112$ & 77.61 & VG & $\mathrm{P}$ \\
\hline 9H-5W, 110-112 & 81.26 & $\mathrm{G}$ & $\mathrm{P}$ \\
\hline $10 \mathrm{H}-2 \mathrm{~W}, 45-47$ & 85.46 & $G$ & $\mathrm{P}$ \\
\hline $10 \mathrm{H}-3 \mathrm{~W}, 90-92$ & 86.59 & VG & $\mathrm{P}$ \\
\hline $10 \mathrm{H}-4 \mathrm{~W}, 90-92$ & 88.06 & $\mathrm{G}$ & $\mathrm{P}$ \\
\hline $10 \mathrm{H}-5 \mathrm{~W}, 90-92$ & 89.16 & $G$ & $\mathrm{P}$ \\
\hline $10 \mathrm{H}-6 \mathrm{~W}, 90-92$ & 90.56 & VG & $\mathrm{P}$ \\
\hline $10 \mathrm{H}-7 \mathrm{~W}, 90-92$ & 91.97 & $G$ & $\mathrm{P}$ \\
\hline $11 \mathrm{H}-2 \mathrm{~W}, 100-102$ & 96.51 & VG & $\mathrm{P}$ \\
\hline $11 \mathrm{H}-5 \mathrm{~W}, 105-107$ & 101.06 & VG & $\mathrm{P}$ \\
\hline $12 \mathrm{H}-2 \mathrm{~W}, 100-102$ & 106.01 & $G$ & $\mathrm{P}$ \\
\hline $12 \mathrm{H}-5 \mathrm{~W}, 100-102$ & 110.51 & $\mathrm{G}$ & $P$ \\
\hline $13 \mathrm{H}-2 \mathrm{~W}, 100-102$ & 114.48 & VG & $\mathrm{P}$ \\
\hline $13 \mathrm{H}-5 \mathrm{~W}, 100-102$ & 118.98 & VG & 1 \\
\hline $15 \mathrm{H}-2 \mathrm{~W}, 58-60$ & 134.07 & VG & 1 \\
\hline $15 \mathrm{H}-4 \mathrm{~W}, 60-62$ & 137.09 & VG & $\mathrm{P}$ \\
\hline $16 \mathrm{H}-2 \mathrm{~W}, 120-122$ & 144.21 & $\mathrm{G}$ & $\mathrm{P}$ \\
\hline $16 \mathrm{H}-4 \mathrm{~W}, 94-96$ & 146.95 & $G$ & $\mathrm{P}$ \\
\hline $17 \mathrm{X}-2 \mathrm{~W}, 110-112$ & 153.61 & VG & 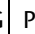 \\
\hline $17 \mathrm{X}-4 \mathrm{~W}, 120-122$ & 156.71 & VG & \\
\hline $18 \mathrm{X}-2 \mathrm{~W}, 100-102$ & 163.11 & $G$ & ( \\
\hline $18 \mathrm{X}-4 \mathrm{~W}, 100-102$ & 166.11 & VG & 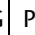 \\
\hline $18 \mathrm{X}-6 \mathrm{~W}, 100-102$ & 169.11 & VG & 1 \\
\hline $19 \mathrm{X}-2 \mathrm{~W}, 100-102$ & 172.71 & VG & 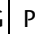 \\
\hline $19 \mathrm{X}-4 \mathrm{~W}, 100-102$ & 175.71 & VG & i \\
\hline $20 \mathrm{X}-2 \mathrm{~W}, 100-102$ & 182.31 & VG & \\
\hline $20 \mathrm{X}-4 \mathrm{~W}, 100-102$ & 185.31 & $G$ & \\
\hline $21 \mathrm{X}-2 \mathrm{~W}, 100-102$ & 191.05 & VG & i \\
\hline $21 \mathrm{X}-4 \mathrm{~W}, 100-102$ & 194.01 & VG & \\
\hline $22 \mathrm{X}-2 \mathrm{~W}, 100-102$ & 201.51 & $G$ & \\
\hline $22 \mathrm{X}-5 \mathrm{~W}, 100-102$ & 206.01 & $G$ & \\
\hline $23 \mathrm{X}-2 \mathrm{~W}, 67-69$ & 210.68 & $G$ & \\
\hline $23 \mathrm{X}-5 \mathrm{~W}, 102-104$ & 215.53 & VG & \\
\hline $24 \mathrm{X}-2 \mathrm{~W}, 52-54$ & 220.03 & $G$ & \\
\hline $24 X-5 W, 37-38$ & 224.38 & $\mathrm{G}$ & \\
\hline
\end{tabular}


Table T11 (continued).

\begin{tabular}{|c|c|c|c|}
\hline $\begin{array}{l}\text { Core, section, } \\
\text { interval }(\mathrm{cm})\end{array}$ & $\begin{array}{l}\text { Depth } \\
\text { (mbsf) }\end{array}$ & 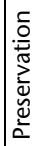 & 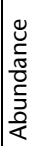 \\
\hline $25 X-2 W, 86-88$ & 229.87 & G & $P$ \\
\hline $25 X-4 W, 13-15$ & 232.14 & $M$ & $P$ \\
\hline $26 X-2 W, 114-115$ & 239.75 & $M$ & $P$ \\
\hline 26X-5W, 97-98 & 244.08 & $M$ & $P$ \\
\hline $27 X-2 W, 71-72$ & 248.92 & $P$ & $P$ \\
\hline $27 X-5 W, 12-13$ & 252.83 & $\mathrm{P}$ & $P$ \\
\hline
\end{tabular}

Preservation: $\mathrm{VG}=$ very good, $\mathrm{G}=$ good, $\mathrm{M}=$ moderate, $\mathrm{P}=$ poor. Abundance: $\mathrm{D}=$ dominant $\mathrm{A}=$ abundant, $\mathrm{F}=$ few, $\mathrm{P}=$ present, $\mathrm{B}=$ barren.

Table T12. Core orientation data, Site U1410.

\begin{tabular}{|c|c|c|c|}
\hline \multicolumn{2}{|c|}{ Hole U1410A } & \multicolumn{2}{|c|}{ Hole U1410B } \\
\hline Core & $\operatorname{MTF}\left({ }^{\circ}\right)$ & Core & $\operatorname{MTF}\left({ }^{\circ}\right)$ \\
\hline \multicolumn{2}{|c|}{ 342-U1410A- } & \multicolumn{2}{|c|}{ 342-U1410B- } \\
\hline $1 \mathrm{H}$ & 129 & $1 \mathrm{H}$ & 158 \\
\hline $2 \mathrm{H}$ & 198 & $2 \mathrm{H}$ & 140 \\
\hline $3 \mathrm{H}$ & 311 & $3 \mathrm{H}$ & 158 \\
\hline $4 \mathrm{H}$ & 34 & $4 \mathrm{H}$ & 119 \\
\hline $5 \mathrm{H}$ & 273 & $5 \mathrm{H}$ & 118 \\
\hline $6 \mathrm{H}$ & 342 & $6 \mathrm{H}$ & 359 \\
\hline $7 \mathrm{H}$ & 228 & $7 \mathrm{H}$ & 216 \\
\hline $8 \mathrm{H}$ & 211 & $8 \mathrm{H}$ & 42 \\
\hline $9 \mathrm{H}$ & 144 & $9 \mathrm{H}$ & 293 \\
\hline $10 \mathrm{H}$ & 288 & $10 \mathrm{H}$ & 39 \\
\hline $11 \mathrm{H}$ & 159 & $11 \mathrm{H}$ & 225 \\
\hline $12 \mathrm{H}$ & 317 & $12 \mathrm{H}$ & 133 \\
\hline $13 \mathrm{H}$ & 52 & $13 \mathrm{H}$ & 356 \\
\hline $14 \mathrm{H}$ & 123 & $14 \mathrm{H}$ & 259 \\
\hline $15 \mathrm{H}$ & 7 & $15 \mathrm{H}$ & 41 \\
\hline \multirow[t]{3}{*}{$16 \mathrm{H}$} & 330 & $16 \mathrm{H}$ & 104 \\
\hline & & $17 \mathrm{H}$ & 166 \\
\hline & & $18 \mathrm{H}$ & 96 \\
\hline
\end{tabular}

MTF = magnetic tool face orientation from geomagnetic north. 
Table T13. Summary of AF demagnetization results for discrete samples, Hole U1410A. (Continued on next page.)

\begin{tabular}{|c|c|c|c|c|c|c|c|}
\hline $\begin{array}{l}\text { Core, section, } \\
\text { interval }(\mathrm{cm})\end{array}$ & $\begin{array}{l}\text { Depth } \\
\text { (mbsf) }\end{array}$ & $\begin{array}{c}\text { Declination } \\
20 \mathrm{mT} \text { or PCA } \\
\left({ }^{\circ}\right)\end{array}$ & $\begin{array}{c}\text { Inclination } \\
20 \mathrm{mT}^{\circ} \text { or PCA } \\
\left({ }^{\circ}\right)\end{array}$ & $\begin{array}{l}\text { PCA } \\
\text { MAD } \\
\left({ }^{\circ}\right)\end{array}$ & $\begin{array}{l}\text { PCA } \\
\text { range } \\
(\mathrm{mT})\end{array}$ & $\begin{array}{l}\mathrm{NRM} \\
20 \mathrm{mT} \\
(\mathrm{A} / \mathrm{m})\end{array}$ & $\begin{array}{l}\text { Measurement } \\
\text { error } \\
\text { (\%) }\end{array}$ \\
\hline \multicolumn{8}{|l|}{ 342-U1410A- } \\
\hline $2 \mathrm{H}-3 \mathrm{~W}, 75-77$ & 12.26 & 227.9 & -39.6 & & & $1.68 \mathrm{E}-03$ & 3.3 \\
\hline $3 \mathrm{H}-4 \mathrm{~W}, 75-77$ & 23.26 & -87.1 & -64.8 & 5.3 & $20-60$ & $6.60 \mathrm{E}-03$ & 4.7 \\
\hline $3 \mathrm{H}-6 \mathrm{~W}, 75-77$ & 26.26 & -65.5 & 33.2 & & & $9.16 \mathrm{E}-03$ & 5.6 \\
\hline $4 \mathrm{H}-3 \mathrm{~W}, 75-77$ & 31.26 & 203.9 & -71.1 & & & $1.49 \mathrm{E}-02$ & 3.5 \\
\hline $4 \mathrm{H}-5 \mathrm{~W}, 75-77$ & 34.26 & -30.0 & 66.7 & & & $5.31 \mathrm{E}-04$ & 3.7 \\
\hline $5 \mathrm{H}-1 \mathrm{~W}, 75-77$ & 37.76 & -73.6 & -23.1 & & & $6.99 \mathrm{E}-05$ & 14.6 \\
\hline $5 \mathrm{H}-2 \mathrm{~W}, 75-77$ & 39.26 & 14.6 & 53.4 & & & $6.53 \mathrm{E}-05$ & 7.8 \\
\hline $5 \mathrm{H}-3 \mathrm{~W}, 75-77$ & 40.76 & 222.0 & -7.8 & & & $1.53 \mathrm{E}-04$ & 12.3 \\
\hline $5 \mathrm{H}-4 \mathrm{~W}, 75-77$ & 42.26 & 6.3 & 67.6 & & & $2.31 \mathrm{E}-03$ & 4.2 \\
\hline $5 \mathrm{H}-5 \mathrm{~W}, 75-77$ & 43.76 & 262.9 & 41.2 & & & $1.12 \mathrm{E}-03$ & 4.5 \\
\hline $5 \mathrm{H}-6 \mathrm{~W}, 50-52$ & 45.01 & 211.1 & -48.4 & & & $3.58 \mathrm{E}-03$ & 5.5 \\
\hline $6 \mathrm{H}-2 \mathrm{~W}, 75-77$ & 48.76 & 13.3 & 35.2 & & & $2.37 \mathrm{E}-04$ & 4.2 \\
\hline $6 \mathrm{H}-3 \mathrm{~W}, 75-77$ & 50.26 & 201.1 & -72.5 & & & $5.26 \mathrm{E}-03$ & 3.7 \\
\hline $6 \mathrm{H}-4 \mathrm{~W}, 75-77$ & 51.76 & -30.3 & 65.1 & & & $4.26 \mathrm{E}-03$ & 2.8 \\
\hline $6 \mathrm{H}-5 \mathrm{~W}, 75-77$ & 53.26 & 21.9 & 66.9 & 5.4 & $10-40$ & $4.04 \mathrm{E}-03$ & 2.5 \\
\hline 7H-1W, 74-76 & 56.75 & -84.5 & 37.9 & & & $2.03 \mathrm{E}-02$ & 3.7 \\
\hline 7H-2W, 74-76 & 58.27 & -83.0 & 18.2 & & & $1.19 \mathrm{E}-02$ & 3.5 \\
\hline $7 \mathrm{H}-3 \mathrm{~W}, 28-30$ & 59.34 & 222.9 & 42.2 & & & $4.21 \mathrm{E}-03$ & 4.7 \\
\hline $7 \mathrm{H}-4 \mathrm{~W}, 54-56$ & 60.22 & 204.9 & 40.8 & 4.1 & $20-60$ & $4.30 \mathrm{E}-03$ & 4.7 \\
\hline $7 \mathrm{H}-5 \mathrm{~W}, 54-56$ & 61.44 & 156.5 & -10.5 & & & $3.39 \mathrm{E}-03$ & 6.7 \\
\hline 7H-6W, 74-76 & 62.78 & 263.2 & 20.0 & & & $3.54 \mathrm{E}-03$ & 3.1 \\
\hline 7H-7W, 74-76 & 64.30 & 196.5 & 55.3 & & & $1.47 \mathrm{E}-04$ & 6.4 \\
\hline $8 \mathrm{H}-1 \mathrm{~W}, 72-74$ & 66.23 & -29.4 & 58.0 & & & $1.09 \mathrm{E}-04$ & 4.3 \\
\hline $8 \mathrm{H}-2 \mathrm{~W}, 74-76$ & 67.75 & -31.6 & 51.1 & & & $1.78 \mathrm{E}-03$ & 5.6 \\
\hline $8 \mathrm{H}-3 \mathrm{~W}, 74-76$ & 69.25 & 209.6 & 40.0 & & & $1.01 \mathrm{E}-03$ & 4.7 \\
\hline $8 \mathrm{H}-4 \mathrm{~W}, 74-76$ & 70.75 & 221.9 & 35.4 & & & $2.13 \mathrm{E}-03$ & 4.1 \\
\hline $8 \mathrm{H}-5 \mathrm{~W}, 74-76$ & 72.25 & -39.4 & 54.0 & & & $6.34 \mathrm{E}-03$ & 4.9 \\
\hline $8 \mathrm{H}-6 \mathrm{~W}, 74-76$ & 73.75 & -26.5 & 53.2 & 5.4 & $20-60$ & $8.44 \mathrm{E}-03$ & 4.7 \\
\hline $8 \mathrm{H}-7 \mathrm{~W}, 20-22$ & 74.71 & -29.9 & 57.3 & & & $8.24 \mathrm{E}-03$ & 4.7 \\
\hline $9 \mathrm{H}-1 \mathrm{~W}, 119-121$ & 76.20 & 71.2 & 54.7 & & & $1.15 \mathrm{E}-02$ & 4.1 \\
\hline $9 \mathrm{H}-2 \mathrm{~W}, 74-76$ & 77.25 & 99.3 & 44.8 & & & $8.67 \mathrm{E}-03$ & 4.8 \\
\hline $9 \mathrm{H}-3 \mathrm{~W}, 32-34$ & 78.33 & 123.7 & 57.4 & 0.7 & $30-60$ & $4.84 \mathrm{E}-03$ & 3.9 \\
\hline $9 \mathrm{H}-4 \mathrm{~W}, 74-76$ & 79.40 & -5.9 & 41.1 & & & $1.04 \mathrm{E}-03$ & 3.9 \\
\hline $9 \mathrm{H}-5 \mathrm{~W}, 74-76$ & 80.90 & -49.2 & 58.2 & & & $2.82 \mathrm{E}-03$ & 4.2 \\
\hline $9 \mathrm{H}-6 \mathrm{~W}, 74-76$ & 82.40 & 109.1 & 6.1 & & & $1.57 \mathrm{E}-04$ & 11.1 \\
\hline $9 \mathrm{H}-7 \mathrm{~W}, 41-43$ & 83.57 & 113.9 & 18.7 & & & $7.85 \mathrm{E}-03$ & 6.1 \\
\hline $10 \mathrm{H}-2 \mathrm{~W}, 49-51$ & 85.50 & 130.5 & 70.1 & & & $3.37 \mathrm{E}-03$ & 3.2 \\
\hline $10 \mathrm{H}-3 \mathrm{~W}, 99-101$ & 86.68 & 71.7 & 31.5 & 7.6 & $20-60$ & $6.64 \mathrm{E}-04$ & 5.7 \\
\hline $10 \mathrm{H}-4 \mathrm{~W}, 77-79$ & 87.93 & -50.7 & 16.4 & & & $2.73 \mathrm{E}-03$ & 4.3 \\
\hline $10 \mathrm{H}-5 \mathrm{~W}, 65-67$ & 88.91 & -68.5 & 10.4 & & & $4.28 \mathrm{E}-03$ & 4.6 \\
\hline $10 \mathrm{H}-6 \mathrm{~W}, 65-67$ & 90.31 & 205.1 & 66.3 & & & $2.21 \mathrm{E}-03$ & 3.5 \\
\hline $10 \mathrm{H}-7 \mathrm{~W}, 50-52$ & 91.57 & 257.0 & 13.2 & & & $1.24 \mathrm{E}-03$ & 7.0 \\
\hline $11 \mathrm{H}-1 \mathrm{~W}, 74-76$ & 94.75 & 180.5 & 40.3 & & & $3.14 \mathrm{E}-03$ & 3.3 \\
\hline $11 \mathrm{H}-2 \mathrm{~W}, 73-75$ & 96.24 & 185.5 & -26.9 & 1.9 & $20-60$ & $4.32 \mathrm{E}-03$ & 3.3 \\
\hline $11 \mathrm{H}-3 \mathrm{~W}, 82-84$ & 97.83 & 29.5 & 61.0 & & & $3.66 \mathrm{E}-05$ & 25.4 \\
\hline $11 \mathrm{H}-4 \mathrm{~W}, 74-76$ & 99.25 & -2.1 & 56.9 & & & $4.53 \mathrm{E}-03$ & 3.5 \\
\hline $11 \mathrm{H}-5 \mathrm{~W}, 74-76$ & 100.75 & -24.7 & 59.2 & & & $2.98 \mathrm{E}-03$ & 3.9 \\
\hline $11 \mathrm{H}-6 \mathrm{~W}, 57-59$ & 102.08 & -31.3 & 72.3 & & & $9.98 \mathrm{E}-04$ & 3.8 \\
\hline $11 \mathrm{H}-7 \mathrm{~W}, 26-28$ & 102.88 & 168.4 & -20.1 & & & 4.19E-05 & 16.0 \\
\hline $12 \mathrm{H}-1 \mathrm{~W}, 110-112$ & 104.61 & 159.9 & 64.7 & & & $4.80 \mathrm{E}-04$ & 3.2 \\
\hline $12 \mathrm{H}-2 \mathrm{~W}, 74-76$ & 105.75 & 113.2 & -57.5 & & & 8.47E-05 & 8.8 \\
\hline $12 \mathrm{H}-3 \mathrm{~W}, 74-76$ & 107.25 & -79.3 & -84.2 & & & $3.69 \mathrm{E}-05$ & 21.1 \\
\hline $12 \mathrm{H}-4 \mathrm{~W}, 74-76$ & 108.75 & 173.0 & -14.8 & & & $8.82 \mathrm{E}-04$ & 4.7 \\
\hline $12 \mathrm{H}-5 \mathrm{~W}, 74-76$ & 110.25 & 244.3 & -38.2 & & & $3.95 \mathrm{E}-04$ & 12.3 \\
\hline $12 \mathrm{H}-6 \mathrm{~W}, 80-82$ & 111.81 & 167.0 & -52.7 & & & $3.56 \mathrm{E}-04$ & 4.6 \\
\hline $13 \mathrm{H}-2 \mathrm{~W}, 74-76$ & 114.22 & 146.7 & -28.1 & & & $1.93 \mathrm{E}-04$ & 4.1 \\
\hline $13 \mathrm{H}-3 \mathrm{~W}, 74-76$ & 115.72 & 169.7 & -33.3 & & & $1.84 \mathrm{E}-03$ & 5.9 \\
\hline $13 \mathrm{H}-4 \mathrm{~W}, 74-76$ & 117.22 & 159.0 & -47.4 & & & $5.27 \mathrm{E}-04$ & 4.5 \\
\hline $13 \mathrm{H}-5 \mathrm{~W}, 74-76$ & 118.72 & 208.8 & -52.1 & & & $9.58 \mathrm{E}-05$ & 9.7 \\
\hline $13 \mathrm{H}-6 \mathrm{~W}, 74-76$ & 120.22 & 162.3 & -43.3 & & & $1.96 \mathrm{E}-04$ & 5.1 \\
\hline $13 \mathrm{H}-7 \mathrm{~W}, 74-76$ & 121.72 & 23.7 & 52.3 & & & $1.43 \mathrm{E}-04$ & 6.9 \\
\hline $14 \mathrm{H}-1 \mathrm{~W}, 74-76$ & 123.25 & -0.5 & 50.5 & & & $2.79 \mathrm{E}-04$ & 4.5 \\
\hline $14 \mathrm{H}-3 \mathrm{~W}, 74-76$ & 126.25 & 39.8 & 41.4 & & & $2.01 \mathrm{E}-03$ & 4.9 \\
\hline $14 \mathrm{H}-4 \mathrm{~W}, 68-70$ & 127.69 & 14.7 & 45.9 & & & $3.48 \mathrm{E}-04$ & 5.6 \\
\hline $14 \mathrm{H}-5 \mathrm{~W}, 74-76$ & 129.25 & -3.6 & 42.1 & 8.4 & $20-60$ & $2.50 \mathrm{E}-04$ & 5.7 \\
\hline
\end{tabular}


Table T13 (continued).

\begin{tabular}{|c|c|c|c|c|c|c|c|}
\hline $\begin{array}{l}\text { Core, section, } \\
\text { interval }(\mathrm{cm})\end{array}$ & $\begin{array}{l}\text { Depth } \\
\text { (mbsf) }\end{array}$ & $\begin{array}{c}\text { Declination } \\
20 \mathrm{mT} \text { or PCA } \\
\left(^{\circ}\right)\end{array}$ & $\begin{array}{c}\text { Inclination } \\
20 \mathrm{mT} \text { or PCA } \\
\left({ }^{\circ}\right)\end{array}$ & $\begin{array}{l}\text { PCA } \\
\text { MAD } \\
\left({ }^{\circ}\right)\end{array}$ & $\begin{array}{l}\text { PCA } \\
\text { range } \\
(\mathrm{mT})\end{array}$ & $\begin{array}{l}\text { NRM } \\
20 \mathrm{mT} \\
(\mathrm{A} / \mathrm{m})\end{array}$ & $\begin{array}{l}\text { Measurement } \\
\text { error } \\
(\%)\end{array}$ \\
\hline $14 \mathrm{H}-6 \mathrm{~W}, 54-56$ & 130.55 & 38.8 & 48.9 & & & $6.30 \mathrm{E}-04$ & 5.9 \\
\hline $15 \mathrm{H}-3 \mathrm{~W}, 75-77$ & 135.74 & 39.8 & 54.8 & & & $1.87 \mathrm{E}-04$ & 2.1 \\
\hline $15 \mathrm{H}-5 \mathrm{~W}, 75-77$ & 138.74 & 39.7 & 28.1 & 10.0 & $20-60$ & $1.45 \mathrm{E}-04$ & 3.3 \\
\hline $16 \mathrm{H}-1 \mathrm{~W}, 75-77$ & 142.26 & 25.4 & 58.8 & & & $2.09 \mathrm{E}-04$ & 2.5 \\
\hline $16 \mathrm{H}-3 \mathrm{~W}, 75-77$ & 145.26 & -23.5 & 22.8 & 5.2 & $10-60$ & 1.17E-04 & 7.1 \\
\hline $16 \mathrm{H}-5 \mathrm{~W}, 75-77$ & 148.26 & -64.0 & 10.1 & & & $1.70 \mathrm{E}-04$ & 10.7 \\
\hline $16 \mathrm{H}-7 \mathrm{~W}, 25-27$ & 150.62 & 81.9 & 53.0 & & & $5.34 \mathrm{E}-05$ & 6.8 \\
\hline $17 X-2 W, 70-72$ & 153.21 & 227.4 & -73.9 & & & $3.04 \mathrm{E}-05$ & 15.1 \\
\hline $17 X-4 W, 75-77$ & 156.26 & 14.8 & -18.5 & & & $4.54 \mathrm{E}-05$ & 1.0 \\
\hline $17 X-6 W, 52-54$ & 159.03 & -19.8 & -48.4 & & & $5.16 \mathrm{E}-05$ & 12.7 \\
\hline $18 X-2 W, 75-77$ & 162.86 & 148.8 & -65.5 & & & $2.79 \mathrm{E}-05$ & 16.3 \\
\hline $18 X-4 W, 75-77$ & 165.86 & 84.6 & -27.7 & & & $6.26 \mathrm{E}-05$ & 7.5 \\
\hline $18 X-6 W, 55-57$ & 168.66 & 24.0 & -31.3 & & & $7.59 \mathrm{E}-05$ & 9.9 \\
\hline $19 X-2 W, 75-77$ & 172.46 & 213.4 & -32.6 & & & $1.04 \mathrm{E}-04$ & 9.1 \\
\hline $19 X-4 W, 75-77$ & 175.46 & -60.3 & -49.5 & 7.6 & $10-60$ & $1.80 \mathrm{E}-04$ & 6.1 \\
\hline 19X-6W, 75-77 & 178.46 & 19.7 & -38.3 & & & $2.84 \mathrm{E}-04$ & 4.4 \\
\hline $20 X-2 W, 81-83$ & 182.12 & -73.3 & -24.2 & & & $1.25 \mathrm{E}-04$ & 9.2 \\
\hline $20 X-4 W, 77-79$ & 185.08 & 220.2 & -43.9 & 8.0 & $20-40$ & $1.14 \mathrm{E}-04$ & 5.3 \\
\hline $20 X-6 W, 65-67$ & 187.96 & -88.0 & -53.5 & & & $3.40 \mathrm{E}-05$ & 11.0 \\
\hline $21 \mathrm{X}-2 \mathrm{~W}, 77-79$ & 190.82 & 207.3 & -50.2 & & & $1.57 \mathrm{E}-04$ & 5.2 \\
\hline $21 X-4 W, 42-44$ & 193.43 & 75.7 & 50.6 & & & $9.21 \mathrm{E}-05$ & 2.3 \\
\hline $21 X-6 W, 90-92$ & 196.78 & 14.0 & -33.7 & & & $4.22 \mathrm{E}-05$ & 15.6 \\
\hline $21 X-7 W, 62-64$ & 198.00 & 174.1 & 29.2 & & & $4.80 \mathrm{E}-05$ & 11.1 \\
\hline $22 X-1 W, 74-76$ & 199.75 & -57.1 & 29.7 & & & $4.96 \mathrm{E}-05$ & 19.3 \\
\hline $22 X-2 W, 76-78$ & 201.27 & 11.8 & 59.1 & & & $1.57 \mathrm{E}-04$ & 6.6 \\
\hline $22 X-4 W, 67-69$ & 204.18 & 211.2 & 49.1 & & & $7.46 \mathrm{E}-05$ & 11.3 \\
\hline $22 X-6 W, 72-74$ & 207.23 & -42.2 & 33.8 & & & $3.47 \mathrm{E}-05$ & 17.0 \\
\hline $23 \mathrm{X}-2 \mathrm{~W}, 109-111$ & 211.10 & 128.0 & 68.4 & & & $1.41 \mathrm{E}-05$ & 26.3 \\
\hline $23 X-4 W, 93-95$ & 213.94 & 82.6 & 15.1 & & & $1.26 \mathrm{E}-04$ & 1.7 \\
\hline $23 \mathrm{X}-6 \mathrm{~W}, 92-94$ & 216.93 & 168.3 & 51.0 & & & $2.45 \mathrm{E}-04$ & 3.4 \\
\hline 23X-7W, 9-11 & 217.60 & 91.5 & 76.4 & & & $3.36 \mathrm{E}-04$ & 3.8 \\
\hline $24 X-1 W, 51-53$ & 218.52 & 66.2 & -51.7 & & & $8.62 \mathrm{E}-05$ & 4.9 \\
\hline $24 \mathrm{X}-2 \mathrm{~W}, 75-77$ & 220.26 & -79.0 & -64.1 & & & $4.78 \mathrm{E}-05$ & 18.2 \\
\hline $24 \mathrm{X}-4 \mathrm{~W}, 52-54$ & 223.03 & 4.7 & -49.3 & & & $5.45 \mathrm{E}-05$ & 11.0 \\
\hline $24 X-6 W, 97-99$ & 226.48 & -89.7 & -54.9 & & & $7.75 \mathrm{E}-05$ & 13.2 \\
\hline $25 X-1 W, 67-69$ & 228.18 & 150.6 & -56.0 & & & $4.85 \mathrm{E}-05$ & 13.5 \\
\hline $25 X-3 W, 84-86$ & 231.35 & 32.1 & -43.0 & & & $7.12 \mathrm{E}-05$ & 14.3 \\
\hline $26 \mathrm{X}-3 \mathrm{~W}, 69-71$ & 240.80 & -76.8 & -40.6 & 2.1 & $20-40$ & $6.79 \mathrm{E}-04$ & 6.7 \\
\hline $26 X-5 W, 95-97$ & 244.06 & 201.8 & -49.1 & & & $5.13 \mathrm{E}-04$ & 4.8 \\
\hline 27X-1W, 104-106 & 247.75 & 34.8 & 65.9 & & & $9.51 \mathrm{E}-04$ & 1.1 \\
\hline $27 X-3 W, 46-48$ & 250.17 & -71.3 & -8.9 & & & $6.95 \mathrm{E}-04$ & 8.5 \\
\hline $27 X-5 W, 74-76$ & 253.45 & 29.2 & -44.5 & & & $2.58 \mathrm{E}-04$ & 4.0 \\
\hline $28 X-1 W, 96-98$ & 257.27 & -69.8 & 14.6 & & & $7.30 \mathrm{E}-04$ & 6.9 \\
\hline $28 X-2 W, 41-43$ & 258.22 & 248.1 & 38.3 & & & $8.90 \mathrm{E}-04$ & 4.4 \\
\hline
\end{tabular}

Declinations for Cores $2 \mathrm{H}$ to $16 \mathrm{H}$ are in geographic coordinates. $\mathrm{PCA}=$ principal component analysis, $\mathrm{MAD}=$ maximum angle of deviation, $\mathrm{NRM}$ $=$ natural remanent magnetism. 
Table T14. Magnetostratigraphic tie points, Site U1410.

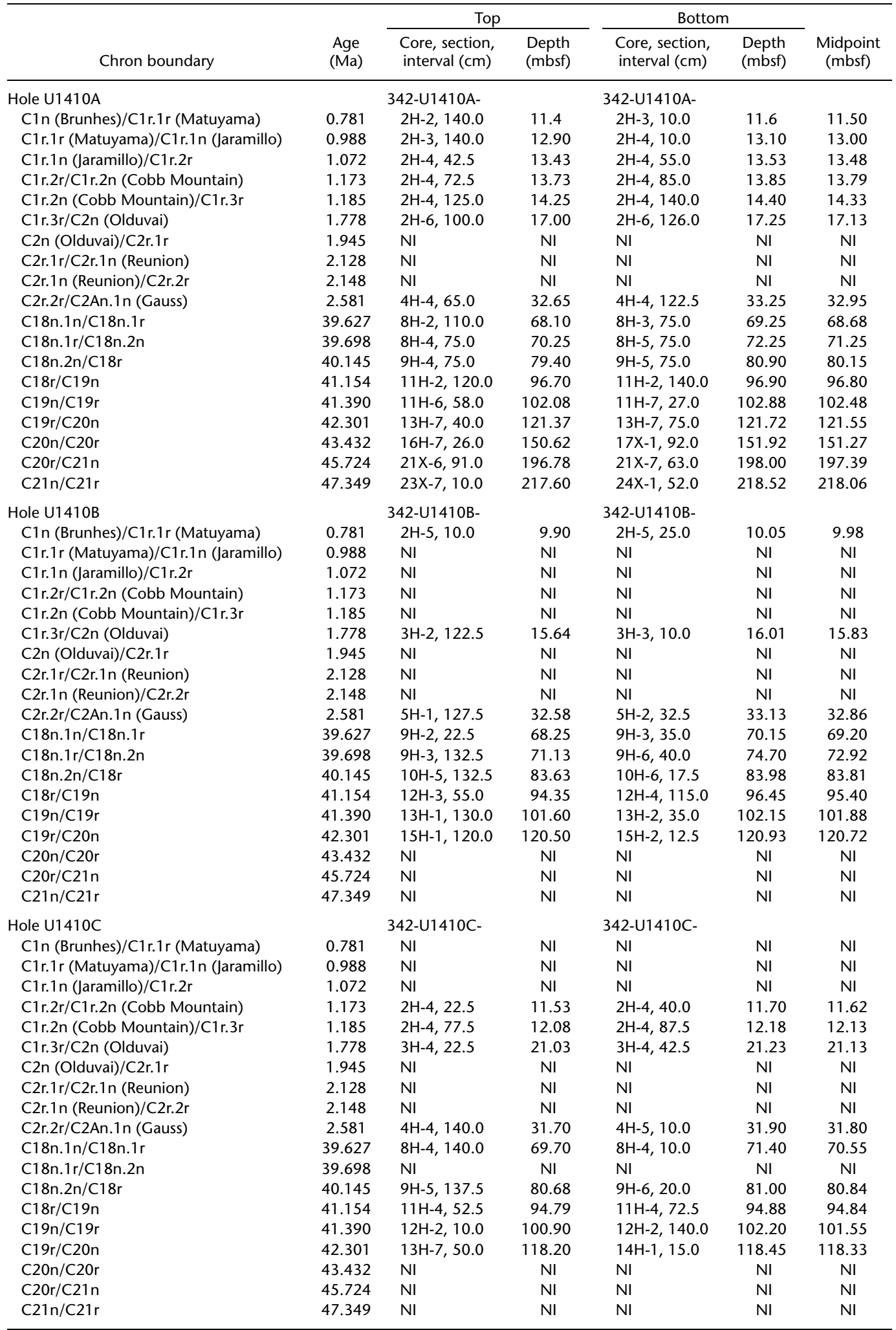

Ages from Gradstein et al. (2012). NI = not identified. 
Table T15. Summary of anisotropy of magnetic susceptibility of discrete samples, Hole U1410A. (Continued on next two pages.)

\begin{tabular}{|c|c|c|c|c|c|c|c|c|c|c|c|c|c|c|c|}
\hline \multirow{2}{*}{$\begin{array}{l}\text { Core, section, } \\
\text { interval }(\mathrm{cm})\end{array}$} & \multirow{2}{*}{$\begin{array}{l}\text { Depth } \\
\text { (mbsf) }\end{array}$} & \multirow[b]{2}{*}{$\tau_{3}$} & \multirow{2}{*}{\multicolumn{2}{|c|}{$\frac{\mathrm{V}_{3}\left({ }^{\circ}\right)}{\text { Declination Inclination }}$}} & \multirow[b]{2}{*}{$\tau_{2}$} & \multirow{2}{*}{\multicolumn{2}{|c|}{$\frac{\mathrm{V}_{2}\left({ }^{\circ}\right)}{\text { Declination Inclination }}$}} & \multirow[b]{2}{*}{$\tau_{1}$} & \multirow{2}{*}{\multicolumn{2}{|c|}{$\frac{\mathrm{V}_{1}\left({ }^{\circ}\right)}{\text { Declination Inclination }}$}} & \multirow{2}{*}{$\begin{array}{l}\text { Bulk } \\
\text { susceptibility } \\
\text { (SI) }\end{array}$} & \multirow{2}{*}{$\begin{array}{l}\text { Anisotropy } \\
(\%)\end{array}$} & \multirow[b]{2}{*}{$P$} & \multirow[b]{2}{*}{$\mathrm{L}$} & \multirow[b]{2}{*}{$\mathrm{F}$} \\
\hline & & & & & & & & & & & & & & & \\
\hline \multicolumn{16}{|l|}{ 342-U1410A- } \\
\hline $1 \mathrm{H}-3 \mathrm{~W}, 75-77$ & 3.76 & 0.3257 & 343.5 & 44.1 & 0.3342 & 245.8 & 7.8 & 0.3402 & 148.0 & 44.8 & $3.07 \mathrm{E}-04$ & 1.4 & 1.045 & 1.018 & 1.026 \\
\hline $1 \mathrm{H}-5 \mathrm{~W}, 60-62$ & 6.61 & 0.3295 & 180.5 & 22.2 & 0.3325 & 89.4 & 2.7 & 0.3379 & 352.8 & 67.6 & $1.90 \mathrm{E}-04$ & 0.8 & 1.026 & 1.016 & 1.009 \\
\hline $2 \mathrm{H}-1 \mathrm{~W}, 75-77$ & 9.26 & 0.3293 & 178.1 & 45.0 & 0.3325 & 271.4 & 3.3 & 0.3381 & 4.7 & 44.8 & $1.38 \mathrm{E}-04$ & 0.9 & 1.027 & 1.017 & 1.010 \\
\hline $2 \mathrm{H}-3 \mathrm{~W}, 75-77$ & 12.26 & 0.3313 & 249.3 & 8.9 & 0.3323 & 76.3 & 81.1 & 0.3364 & 339.5 & 1.1 & $1.39 \mathrm{E}-04$ & 0.5 & 1.015 & 1.012 & 1.003 \\
\hline $2 \mathrm{H}-5 \mathrm{~W}, 75-77$ & 15.26 & 0.3274 & 134.9 & 7.7 & 0.3330 & 30.4 & 61.6 & 0.3396 & 228.9 & 27.1 & $1.74 \mathrm{E}-04$ & 1.2 & 1.037 & 1.020 & 1.017 \\
\hline $2 \mathrm{H}-7 \mathrm{~W}, 35-37$ & 17.86 & 0.3299 & 82.2 & 9.6 & 0.3336 & 348.2 & 22.8 & 0.3364 & 193.5 & 65.1 & $2.70 \mathrm{E}-04$ & 0.6 & 1.020 & 1.008 & 1.011 \\
\hline $3 \mathrm{H}-1 \mathrm{~W}, 75-77$ & 18.76 & 0.3308 & 173.3 & 9.7 & 0.3329 & 263.4 & 0.5 & 0.3362 & 356.0 & 80.3 & 4.71E-04 & 0.5 & 1.016 & 1.010 & 1.006 \\
\hline $3 \mathrm{H}-3 \mathrm{~W}, 75-77$ & 21.76 & 0.3300 & 167.2 & 49.0 & 0.3340 & 76.6 & 0.6 & 0.3360 & 346.1 & 41.0 & $2.21 \mathrm{E}-04$ & 0.6 & 1.018 & 1.006 & 1.012 \\
\hline $3 \mathrm{H}-5 \mathrm{~W}, 75-77$ & 24.76 & 0.3259 & 242.9 & 7.1 & 0.3353 & 141.8 & 57.1 & 0.3388 & 337.3 & 32.0 & $6.73 \mathrm{E}-04$ & 1.3 & 1.040 & 1.010 & 1.029 \\
\hline $3 \mathrm{H}-7 \mathrm{~W}, 35-37$ & 27.36 & 0.3321 & 179.3 & 42.3 & 0.3330 & 78.0 & 12.2 & 0.3349 & 335.5 & 45.2 & $5.15 \mathrm{E}-04$ & 0.3 & 1.009 & 1.006 & 1.003 \\
\hline $4 \mathrm{H}-1 \mathrm{~W}, 75-77$ & 28.26 & 0.3283 & 133.1 & 83.5 & 0.3346 & 280.3 & 5.5 & 0.3372 & 10.6 & 3.5 & $4.87 \mathrm{E}-04$ & 0.9 & 1.027 & 1.008 & 1.019 \\
\hline $4 \mathrm{H}-3 \mathrm{~W}, 75-77$ & 31.26 & 0.3308 & 100.1 & 74.8 & 0.3339 & 240.5 & 11.8 & 0.3353 & 332.5 & 9.4 & $6.43 \mathrm{E}-04$ & 0.5 & 1.014 & 1.004 & 1.009 \\
\hline $4 \mathrm{H}-5 \mathrm{~W}, 75-77$ & 34.26 & 0.3309 & 85.8 & 11.9 & 0.3329 & 217.9 & 72.5 & 0.3361 & 353.1 & 12.6 & $1.82 \mathrm{E}-04$ & 0.5 & 1.016 & 1.010 & 1.006 \\
\hline $4 \mathrm{H}-7 \mathrm{~W}, 35-37$ & 36.86 & 0.3287 & 90.3 & 67.9 & 0.3327 & 273.2 & 22.0 & 0.3386 & 182.8 & 1.0 & $9.59 \mathrm{E}-05$ & 1.0 & 1.030 & 1.018 & 1.012 \\
\hline $5 \mathrm{H}-1 \mathrm{~W}, 75-77$ & 37.76 & 0.3284 & 230.9 & 70.0 & 0.3348 & 58.9 & 19.9 & 0.3368 & 328.0 & 2.6 & $9.17 \mathrm{E}-05$ & 0.8 & 1.025 & 1.006 & 1.020 \\
\hline $5 \mathrm{H}-3 \mathrm{~W}, 75-77$ & 40.76 & 0.3301 & 229.9 & 8.7 & 0.3334 & 338.9 & 64.8 & 0.3365 & 136.1 & 23.5 & $8.93 \mathrm{E}-05$ & 0.6 & 1.020 & 1.009 & 1.010 \\
\hline $5 \mathrm{H}-5 \mathrm{~W}, 75-77$ & 43.76 & 0.3303 & 90.9 & 82.8 & 0.3341 & 264.2 & 7.1 & 0.3356 & 354.3 & 0.8 & $2.54 \mathrm{E}-04$ & 0.5 & 1.016 & 1.005 & 1.011 \\
\hline $5 \mathrm{H}-7 \mathrm{~W}, 25-27$ & 45.87 & 0.3297 & 218.3 & 76.0 & 0.3344 & 335.0 & 6.4 & 0.3359 & 66.4 & 12.4 & $2.94 \mathrm{E}-04$ & 0.6 & 1.019 & 1.004 & 1.014 \\
\hline $6 \mathrm{H}-1 \mathrm{~W}, 100-102$ & 47.51 & 0.3312 & 180.5 & 80.4 & 0.3339 & 298.8 & 4.6 & 0.3350 & 29.5 & 8.5 & $2.66 \mathrm{E}-04$ & 0.4 & 1.011 & 1.003 & 1.008 \\
\hline $6 \mathrm{H}-3 \mathrm{~W}, 75-77$ & 50.26 & 0.3300 & 119.3 & 77.2 & 0.3340 & 294.2 & 12.8 & 0.3360 & 24.5 & 1.1 & $2.20 \mathrm{E}-04$ & 0.6 & 1.018 & 1.006 & 1.012 \\
\hline $6 \mathrm{H}-5 \mathrm{~W}, 75-77$ & 53.26 & 0.3296 & 191.1 & 86.3 & 0.3349 & 306.6 & 1.6 & 0.3355 & 36.7 & 3.3 & $4.14 \mathrm{E}-04$ & 0.6 & 1.018 & 1.002 & 1.016 \\
\hline $6 \mathrm{H}-7 \mathrm{~W}, 28-30$ & 55.70 & 0.3295 & 102.4 & 63.6 & 0.3347 & 3.8 & 4.3 & 0.3358 & 271.7 & 26.0 & $1.18 \mathrm{E}-04$ & 0.6 & 1.019 & 1.003 & 1.016 \\
\hline 7H-1W, 74-76 & 56.75 & 0.3304 & 114.7 & 69.6 & 0.3346 & 10.7 & 5.1 & 0.3350 & 278.9 & 19.7 & $2.33 \mathrm{E}-04$ & 0.5 & 1.014 & 1.001 & 1.013 \\
\hline $7 \mathrm{H}-3 \mathrm{~W}, 28-30$ & 59.34 & 0.3298 & 135.4 & 70.2 & 0.3347 & 267.2 & 13.5 & 0.3355 & 0.7 & 14.2 & $1.62 \mathrm{E}-04$ & 0.6 & 1.017 & 1.002 & 1.015 \\
\hline 7H-5W, 54-56 & 61.44 & 0.3298 & 119.4 & 70.7 & 0.3345 & 250.1 & 12.9 & 0.3357 & 343.4 & 14.1 & $2.13 \mathrm{E}-04$ & 0.6 & 1.018 & 1.003 & 1.014 \\
\hline 7H-7W, 74-76 & 64.30 & 0.3305 & 167.9 & 69.5 & 0.3338 & 289.7 & 11.2 & 0.3357 & 23.2 & 17.0 & $9.06 \mathrm{E}-05$ & 0.5 & 1.016 & 1.006 & 1.010 \\
\hline $8 \mathrm{H}-1 \mathrm{~W}, 72-74$ & 66.23 & 0.3276 & 125.1 & 85.3 & 0.3350 & 302.7 & 4.7 & 0.3374 & 32.7 & 0.2 & $7.92 \mathrm{E}-05$ & 1.0 & 1.030 & 1.007 & 1.023 \\
\hline $8 \mathrm{H}-2 \mathrm{~W}, 74-76$ & 67.75 & 0.3307 & 15.4 & 85.0 & 0.3340 & 198.5 & 5.0 & 0.3353 & 108.5 & 0.3 & $8.11 \mathrm{E}-05$ & 0.5 & 1.014 & 1.004 & 1.010 \\
\hline $8 \mathrm{H}-3 \mathrm{~W}, 74-76$ & 69.25 & 0.3311 & 145.4 & 48.9 & 0.3330 & 307.4 & 39.7 & 0.3359 & 45.0 & 9.0 & $6.97 \mathrm{E}-05$ & 0.5 & 1.014 & 1.009 & 1.006 \\
\hline $8 \mathrm{H}-4 \mathrm{~W}, 74-76$ & 70.75 & 0.3299 & 198.2 & 80.6 & 0.3337 & 82.8 & 4.1 & 0.3364 & 352.2 & 8.5 & $1.34 \mathrm{E}-04$ & 0.6 & 1.019 & 1.008 & 1.011 \\
\hline $8 \mathrm{H}-5 \mathrm{~W}, 74-76$ & 72.25 & 0.3319 & 101.9 & 52.4 & 0.3332 & 339.8 & 22.3 & 0.3349 & 236.9 & 28.6 & $1.15 \mathrm{E}-04$ & 0.3 & 1.009 & 1.005 & 1.004 \\
\hline $8 \mathrm{H}-6 \mathrm{~W}, 74-76$ & 73.75 & 0.3317 & 74.1 & 45.6 & 0.3334 & 263.7 & 44.0 & 0.3348 & 169.0 & 4.9 & $1.25 \mathrm{E}-04$ & 0.3 & 1.009 & 1.004 & 1.005 \\
\hline $8 \mathrm{H}-7 \mathrm{~W}, 20-22$ & 74.71 & 0.3319 & 149.0 & 52.8 & 0.3327 & 332.1 & 37.2 & 0.3354 & 241.0 & 1.5 & $1.23 \mathrm{E}-04$ & 0.4 & 1.011 & 1.008 & 1.002 \\
\hline $9 \mathrm{H}-1 \mathrm{~W}, 119-121$ & 76.20 & 0.3295 & 234.9 & 59.9 & 0.3335 & 43.8 & 29.6 & 0.3370 & 136.5 & 4.8 & $1.63 \mathrm{E}-04$ & 0.7 & 1.023 & 1.010 & 1.012 \\
\hline $9 \mathrm{H}-2 \mathrm{~W}, 74-76$ & 77.25 & 0.3312 & 227.1 & 57.0 & 0.3339 & 14.6 & 28.7 & 0.3349 & 112.9 & 14.9 & $1.69 \mathrm{E}-04$ & 0.4 & 1.011 & 1.003 & 1.008 \\
\hline $9 \mathrm{H}-3 \mathrm{~W}, 32-34$ & 78.33 & 0.3303 & 54.2 & 78.4 & 0.3336 & 281.9 & 7.9 & 0.3361 & 190.7 & 8.5 & $1.14 \mathrm{E}-04$ & 0.6 & 1.018 & 1.007 & 1.010 \\
\hline $9 \mathrm{H}-4 \mathrm{~W}, 74-76$ & 79.40 & 0.3273 & 215.6 & 67.6 & 0.3353 & 120.6 & 2.0 & 0.3374 & 29.8 & 22.3 & $9.39 \mathrm{E}-05$ & 1.0 & 1.031 & 1.006 & 1.025 \\
\hline $9 \mathrm{H}-5 \mathrm{~W}, 74-76$ & 80.90 & 0.3316 & 51.2 & 72.7 & 0.3336 & 219.8 & 17.0 & 0.3349 & 310.8 & 3.2 & $1.05 \mathrm{E}-04$ & 0.3 & 1.010 & 1.004 & 1.006 \\
\hline $9 \mathrm{H}-6 \mathrm{~W}, 74-76$ & 82.40 & 0.3278 & 159.5 & 77.6 & 0.3352 & 260.5 & 2.4 & 0.3371 & 351.1 & 12.2 & $8.03 \mathrm{E}-05$ & 0.9 & 1.028 & 1.006 & 1.023 \\
\hline $9 \mathrm{H}-7 \mathrm{~W}, 41-43$ & 83.57 & 0.3314 & 199.6 & 80.0 & 0.3340 & 33.9 & 9.7 & 0.3345 & 303.5 & 2.4 & $1.50 \mathrm{E}-04$ & 0.3 & 1.009 & 1.002 & 1.008 \\
\hline $10 \mathrm{H}-2 \mathrm{~W}, 49-51$ & 85.50 & 0.3323 & 173.2 & 82.5 & 0.3334 & 295.4 & 4.0 & 0.3343 & 25.9 & 6.4 & $1.70 \mathrm{E}-04$ & 0.2 & 1.006 & 1.003 & 1.003 \\
\hline $10 \mathrm{H}-3 \mathrm{~W}, 99-101$ & 86.68 & 0.3327 & 289.1 & 6.2 & 0.3334 & 24.3 & 39.4 & 0.3340 & 191.7 & 49.9 & $1.45 \mathrm{E}-04$ & 0.1 & 1.004 & 1.002 & 1.002 \\
\hline $10 \mathrm{H}-4 \mathrm{~W}, 77-79$ & 87.93 & 0.3304 & 120.4 & 69.8 & 0.3341 & 270.4 & 17.6 & 0.3354 & 3.4 & 9.5 & $1.09 \mathrm{E}-04$ & 0.5 & 1.015 & 1.004 & 1.011 \\
\hline $10 \mathrm{H}-5 \mathrm{~W}, 65-67$ & 88.91 & 0.3305 & 97.9 & 80.4 & 0.3343 & 339.8 & 4.6 & 0.3352 & 249.1 & 8.5 & $1.24 \mathrm{E}-04$ & 0.5 & 1.014 & 1.003 & 1.012 \\
\hline $10 \mathrm{H}-6 \mathrm{~W}, 65-67$ & 90.31 & 0.3309 & 245.9 & 81.6 & 0.3341 & 59.1 & 8.4 & 0.3350 & 149.2 & 1.0 & $1.15 \mathrm{E}-04$ & 0.4 & 1.013 & 1.003 & 1.010 \\
\hline $10 \mathrm{H}-7 \mathrm{~W}, 50-52$ & 91.57 & 0.3326 & 20.8 & 76.0 & 0.3333 & 145.9 & 8.1 & 0.3341 & 237.5 & 11.3 & $1.06 \mathrm{E}-04$ & 0.2 & 1.005 & 1.002 & 1.002 \\
\hline $11 \mathrm{H}-1 \mathrm{~W}, 74-76$ & 94.75 & 0.3316 & 70.3 & 82.1 & 0.3339 & 281.9 & 6.7 & 0.3345 & 191.5 & 4.1 & $1.30 \mathrm{E}-04$ & 0.3 & 1.009 & 1.002 & 1.007 \\
\hline $11 \mathrm{H}-2 \mathrm{~W}, 73-75$ & 96.24 & 0.3325 & 127.9 & 81.6 & 0.3333 & 281.5 & 7.6 & 0.3342 & 12.0 & 3.7 & $1.29 \mathrm{E}-04$ & 0.2 & 1.005 & 1.003 & 1.003 \\
\hline $11 \mathrm{H}-3 \mathrm{~W}, 82-84$ & 97.83 & 0.3284 & 310.7 & 80.4 & 0.3344 & 107.2 & 8.9 & 0.3372 & 197.8 & 3.8 & $4.28 \mathrm{E}-05$ & 0.9 & 1.027 & 1.008 & 1.018 \\
\hline
\end{tabular}


Table T15 (continued). (Continued on next page.)

\begin{tabular}{|c|c|c|c|c|c|c|c|c|c|c|c|c|c|c|c|}
\hline \multirow{2}{*}{$\begin{array}{l}\text { Core, section, } \\
\text { interval }(\mathrm{cm})\end{array}$} & \multirow{2}{*}{$\begin{array}{l}\text { Depth } \\
\text { (mbsf) }\end{array}$} & \multirow[b]{2}{*}{$\tau_{3}$} & \multicolumn{2}{|c|}{$V_{3}\left(^{\circ}\right)$} & \multirow[b]{2}{*}{$\tau_{2}$} & \multicolumn{2}{|c|}{$V_{2}\left(^{\circ}\right)$} & \multirow[b]{2}{*}{$\tau_{1}$} & \multicolumn{2}{|c|}{$V_{1}\left({ }^{\circ}\right)$} & \multirow{2}{*}{$\begin{array}{c}\text { Bulk } \\
\text { susceptibility } \\
\text { (SI) }\end{array}$} & \multirow{2}{*}{$\begin{array}{l}\text { Anisotropy } \\
(\%)\end{array}$} & \multirow[b]{2}{*}{$P$} & \multirow[b]{2}{*}{$\mathrm{L}$} & \multirow[b]{2}{*}{$\mathrm{F}$} \\
\hline & & & Declination & nclination & & Declination & Inclination & & Declination & Inclination & & & & & \\
\hline $11 \mathrm{H}-4 \mathrm{~W}, 74-76$ & 99.25 & 0.3300 & 239.1 & 81.5 & 0.3342 & 353.8 & 3.6 & 0.3358 & 84.3 & 7.7 & $1.25 \mathrm{E}-04$ & 0.6 & 1.017 & 1.005 & 1.013 \\
\hline $11 \mathrm{H}-5 \mathrm{~W}, 74-76$ & 100.75 & 0.3303 & 222.7 & 72.0 & 0.3337 & 100.4 & 9.9 & 0.3360 & 7.7 & 14.9 & $9.98 \mathrm{E}-05$ & 0.6 & 1.017 & 1.007 & 1.010 \\
\hline $11 \mathrm{H}-6 \mathrm{~W}, 57-59$ & 102.08 & 0.3307 & 99.7 & 88.3 & 0.3330 & 269.1 & 1.7 & 0.3363 & 359.1 & 0.3 & $1.01 \mathrm{E}-04$ & 0.6 & 1.017 & 1.010 & 1.007 \\
\hline $11 \mathrm{H}-7 \mathrm{~W}, 26-28$ & 102.88 & 0.3288 & 164.4 & 76.5 & 0.3349 & 27.5 & 9.9 & 0.3364 & 295.9 & 9.0 & 5.77E-05 & 0.8 & 1.023 & 1.004 & 1.019 \\
\hline $12 \mathrm{H}-1 \mathrm{~W}, 110-112$ & 104.61 & 0.3310 & 355.5 & 76.1 & 0.3335 & 254.1 & 2.8 & 0.3355 & 163.4 & 13.7 & 8.07E-05 & 0.4 & 1.013 & 1.006 & 1.007 \\
\hline $12 \mathrm{H}-2 \mathrm{~W}, 74-76$ & 105.75 & 0.3279 & 293.8 & 74.8 & 0.3335 & 113.7 & 15.2 & 0.3386 & 203.7 & 0.0 & $6.46 \mathrm{E}-05$ & 1.1 & 1.033 & 1.015 & 1.017 \\
\hline $12 \mathrm{H}-3 \mathrm{~W}, 74-76$ & 107.25 & 0.3287 & 119.8 & 81.5 & 0.3346 & 271.5 & 7.5 & 0.3367 & 2.0 & 4.0 & $8.35 \mathrm{E}-05$ & 0.8 & 1.024 & 1.006 & 1.018 \\
\hline $12 \mathrm{H}-5 \mathrm{~W}, 74-76$ & 110.25 & 0.3298 & 357.7 & 65.2 & 0.3332 & 205.8 & 22.2 & 0.3370 & 111.5 & 10.6 & 7.34E-05 & 0.7 & 1.022 & 1.012 & 1.010 \\
\hline $12 \mathrm{H}-6 \mathrm{~W}, 80-82$ & 111.81 & 0.3314 & 93.4 & 61.9 & 0.3329 & 222.7 & 18.7 & 0.3357 & 319.9 & 20.2 & $6.75 \mathrm{E}-05$ & 0.4 & 1.013 & 1.009 & 1.004 \\
\hline $12 \mathrm{H}-7 \mathrm{~W}, 35-37$ & 112.86 & 0.3286 & 160.8 & 59.5 & 0.3346 & 339.5 & 30.5 & 0.3368 & 69.8 & 0.6 & 7.04E-05 & 0.8 & 1.025 & 1.007 & 1.018 \\
\hline $13 \mathrm{H}-2 \mathrm{~W}, 74-76$ & 114.22 & 0.3288 & 94.9 & 87.7 & 0.3344 & 213.6 & 1.1 & 0.3367 & 303.6 & 2.0 & $8.61 \mathrm{E}-05$ & 0.8 & 1.024 & 1.007 & 1.017 \\
\hline $13 \mathrm{H}-3 \mathrm{~W}, 74-76$ & 115.72 & 0.3296 & 105.4 & 45.4 & 0.3333 & 329.6 & 35.2 & 0.3371 & 221.7 & 23.6 & $1.12 \mathrm{E}-04$ & 0.8 & 1.023 & 1.011 & 1.011 \\
\hline $13 \mathrm{H}-4 \mathrm{~W}, 74-76$ & 117.22 & 0.3296 & 229.6 & 60.6 & 0.3330 & 48.9 & 29.4 & 0.3374 & 139.1 & 0.3 & $1.18 \mathrm{E}-04$ & 0.8 & 1.024 & 1.013 & 1.010 \\
\hline $13 \mathrm{H}-5 \mathrm{~W}, 74-76$ & 118.72 & 0.3294 & 49.2 & 77.8 & 0.3345 & 236.3 & 12.1 & 0.3362 & 146.0 & 1.5 & $9.18 \mathrm{E}-05$ & 0.7 & 1.021 & 1.005 & 1.016 \\
\hline $13 \mathrm{H}-6 \mathrm{~W}, 74-76$ & 120.22 & 0.3302 & 239.9 & 82.1 & 0.3324 & 66.9 & 7.9 & 0.3374 & 336.8 & 1.0 & $8.88 \mathrm{E}-05$ & 0.7 & 1.022 & 1.015 & 1.006 \\
\hline $13 \mathrm{H}-7 \mathrm{~W}, 74-76$ & 121.72 & 0.3300 & 267.9 & 59.2 & 0.3327 & 107.7 & 29.3 & 0.3373 & 12.8 & 8.7 & $8.42 \mathrm{E}-05$ & 0.7 & 1.022 & 1.014 & 1.008 \\
\hline $14 \mathrm{H}-1 \mathrm{~W}, 74-76$ & 123.25 & 0.3297 & 133.0 & 62.0 & 0.3342 & 286.1 & 25.4 & 0.3361 & 21.4 & 11.1 & $7.43 \mathrm{E}-05$ & 0.6 & 1.019 & 1.006 & 1.013 \\
\hline $14 \mathrm{H}-2 \mathrm{~W}, 74-76$ & 124.75 & 0.3286 & 286.5 & 50.0 & 0.3351 & 34.9 & 14.9 & 0.3363 & 136.1 & 36.2 & $6.73 \mathrm{E}-05$ & 0.8 & 1.023 & 1.003 & 1.020 \\
\hline $14 \mathrm{H}-3 \mathrm{~W}, 74-76$ & 126.25 & 0.3311 & 79.9 & 83.2 & 0.3340 & 255.1 & 6.8 & 0.3349 & 345.1 & 0.6 & $1.25 \mathrm{E}-04$ & 0.4 & 1.011 & 1.003 & 1.009 \\
\hline $14 \mathrm{H}-4 \mathrm{~W}, 68-70$ & 127.69 & 0.3300 & 249.3 & 69.2 & 0.3323 & 104.1 & 17.3 & 0.3377 & 10.6 & 11.2 & $6.62 \mathrm{E}-05$ & 0.8 & 1.023 & 1.016 & 1.007 \\
\hline $14 \mathrm{H}-5 \mathrm{~W}, 74-76$ & 129.25 & 0.3320 & 273.4 & 30.0 & 0.3336 & 5.9 & 4.4 & 0.3344 & 103.3 & 59.6 & $8.93 \mathrm{E}-05$ & 0.2 & 1.007 & 1.003 & 1.005 \\
\hline $14 \mathrm{H}-6 \mathrm{~W}, 54-56$ & 130.55 & 0.3313 & 250.0 & 53.8 & 0.3339 & 116.9 & 26.5 & 0.3348 & 14.9 & 22.7 & $7.76 \mathrm{E}-05$ & 0.3 & 1.010 & 1.003 & 1.008 \\
\hline $14 \mathrm{H}-7 \mathrm{~W}, 30-32$ & 131.53 & 0.3318 & 87.3 & 55.8 & 0.3322 & 275.8 & 33.9 & 0.3359 & 183.1 & 4.0 & $9.93 \mathrm{E}-05$ & 0.4 & 1.012 & 1.011 & 1.001 \\
\hline $15 \mathrm{H}-2 \mathrm{~W}, 75-77$ & 134.24 & 0.3309 & 86.7 & 54.2 & 0.3342 & 242.8 & 33.4 & 0.3349 & 340.5 & 11.4 & $1.11 \mathrm{E}-04$ & 0.4 & 1.012 & 1.002 & 1.010 \\
\hline $15 \mathrm{H}-3 \mathrm{~W}, 75-77$ & 135.74 & 0.3293 & 66.9 & 82.3 & 0.3344 & 276.5 & 6.7 & 0.3363 & 186.1 & 3.8 & $9.65 \mathrm{E}-05$ & 0.7 & 1.021 & 1.006 & 1.015 \\
\hline $15 \mathrm{H}-4 \mathrm{~W}, 75-77$ & 137.24 & 0.3312 & 42.0 & 70.9 & 0.3338 & 158.7 & 8.8 & 0.3350 & 251.4 & 16.8 & 7.17E-05 & 0.4 & 1.011 & 1.003 & 1.008 \\
\hline $15 \mathrm{H}-5 \mathrm{~W}, 75-77$ & 138.74 & 0.3305 & 83.7 & 80.5 & 0.3343 & 284.6 & 8.9 & 0.3352 & 194.1 & 3.3 & $9.91 \mathrm{E}-05$ & 0.5 & 1.014 & 1.003 & 1.012 \\
\hline $15 \mathrm{H}-6 \mathrm{~W}, 40-42$ & 139.89 & 0.3304 & 48.4 & 61.1 & 0.3335 & 185.7 & 22.1 & 0.3361 & 283.2 & 17.7 & $1.06 \mathrm{E}-04$ & 0.6 & 1.017 & 1.008 & 1.009 \\
\hline $15 \mathrm{H}-7 \mathrm{~W}, 30-32$ & 140.80 & 0.3300 & 77.9 & 68.4 & 0.3342 & 266.7 & 21.4 & 0.3358 & 175.5 & 3.0 & $1.06 \mathrm{E}-04$ & 0.6 & 1.018 & 1.005 & 1.013 \\
\hline $16 \mathrm{H}-1 \mathrm{~W}, 75-77$ & 142.26 & 0.3285 & 123.5 & 56.2 & 0.3345 & 253.8 & 23.4 & 0.3370 & 354.3 & 23.0 & 7.67E-05 & 0.8 & 1.026 & 1.007 & 1.018 \\
\hline $16 \mathrm{H}-2 \mathrm{~W}, 75-77$ & 143.76 & 0.3306 & 65.2 & 49.2 & 0.3329 & 227.3 & 39.4 & 0.3365 & 324.7 & 9.0 & $8.83 \mathrm{E}-05$ & 0.6 & 1.018 & 1.011 & 1.007 \\
\hline $16 \mathrm{H}-3 \mathrm{~W}, 75-77$ & 145.26 & 0.3293 & 292.5 & 76.1 & 0.3329 & 93.9 & 13.2 & 0.3378 & 184.9 & 4.3 & $9.08 \mathrm{E}-05$ & 0.9 & 1.026 & 1.015 & 1.011 \\
\hline $16 \mathrm{H}-4 \mathrm{~W}, 75-77$ & 146.76 & 0.3300 & 194.7 & 74.1 & 0.3329 & 292.3 & 2.2 & 0.3370 & 22.9 & 15.8 & $9.69 \mathrm{E}-05$ & 0.7 & 1.021 & 1.012 & 1.009 \\
\hline $16 \mathrm{H}-5 \mathrm{~W}, 75-77$ & 148.26 & 0.3291 & 16.5 & 67.2 & 0.3337 & 106.5 & 0.0 & 0.3372 & 196.5 & 22.8 & $8.44 \mathrm{E}-05$ & 0.8 & 1.024 & 1.010 & 1.014 \\
\hline $16 \mathrm{H}-6 \mathrm{~W}, 60-62$ & 149.61 & 0.3312 & 315.2 & 47.5 & 0.3335 & 76.6 & 25.5 & 0.3353 & 183.5 & 31.4 & 8.67E-05 & 0.4 & 1.012 & 1.005 & 1.007 \\
\hline $16 \mathrm{H}-7 \mathrm{~W}, 25-27$ & 150.62 & 0.3306 & 76.0 & 76.2 & 0.3337 & 202.1 & 8.3 & 0.3357 & 293.7 & 11.0 & $9.70 \mathrm{E}-05$ & 0.5 & 1.015 & 1.006 & 1.009 \\
\hline $17 X-1 W, 91-93$ & 151.92 & 0.3250 & 250.2 & 48.9 & 0.3363 & 95.2 & 38.3 & 0.3386 & 355.0 & 12.6 & $6.97 \mathrm{E}-05$ & 1.4 & 1.042 & 1.007 & 1.035 \\
\hline $17 \mathrm{X}-2 \mathrm{~W}, 70-72$ & 153.21 & 0.3269 & 220.3 & 30.4 & 0.3349 & 12.8 & 56.5 & 0.3382 & 122.7 & 12.7 & $7.14 \mathrm{E}-05$ & 1.1 & 1.035 & 1.010 & 1.025 \\
\hline $17 X-3 W, 75-77$ & 154.76 & 0.3308 & 312.3 & 59.6 & 0.3322 & 218.5 & 2.2 & 0.3370 & 127.2 & 30.3 & $6.48 \mathrm{E}-05$ & 0.6 & 1.019 & 1.014 & 1.004 \\
\hline $17 X-5 W, 119-121$ & 158.20 & 0.3300 & 78.7 & 43.7 & 0.3347 & 272.1 & 45.5 & 0.3353 & 175.2 & 6.7 & $7.53 \mathrm{E}-05$ & 0.5 & 1.016 & 1.002 & 1.014 \\
\hline $17 X-7 W, 23-25$ & 160.15 & 0.3292 & 275.7 & 60.4 & 0.3314 & 178.2 & 4.2 & 0.3394 & 85.9 & 29.2 & $6.11 \mathrm{E}-05$ & 1.0 & 1.031 & 1.024 & 1.007 \\
\hline 18X-1W, 90-92 & 161.51 & 0.3275 & 250.1 & 76.3 & 0.3350 & 58.1 & 13.4 & 0.3375 & 148.8 & 2.8 & 7.46E-05 & 1.0 & 1.030 & 1.007 & 1.023 \\
\hline $18 X-3 W, 75-77$ & 164.36 & 0.3255 & 288.2 & 43.1 & 0.3350 & 107.0 & 47.0 & 0.3395 & 197.6 & 0.6 & $5.44 \mathrm{E}-05$ & 1.4 & 1.043 & 1.014 & 1.029 \\
\hline $18 X-5 W, 75-77$ & 167.36 & 0.3287 & 119.7 & 82.9 & 0.3348 & 341.8 & 5.3 & 0.3366 & 251.4 & 4.8 & $6.69 \mathrm{E}-05$ & 0.8 & 1.024 & 1.005 & 1.019 \\
\hline 18X-7W, 30-32 & 169.73 & 0.3300 & 99.9 & 47.1 & 0.3328 & 327.9 & 31.8 & 0.3372 & 220.8 & 25.5 & $8.04 \mathrm{E}-05$ & 0.7 & 1.022 & 1.013 & 1.008 \\
\hline 19X-1W, 83-85 & 171.04 & 0.3296 & 257.4 & 42.6 & 0.3348 & 142.1 & 24.9 & 0.3356 & 31.5 & 37.1 & $8.41 \mathrm{E}-05$ & 0.6 & 1.018 & 1.003 & 1.016 \\
\hline 19X-3W, 77-79 & 173.98 & 0.3293 & 248.7 & 84.8 & 0.3344 & 50.7 & 5.0 & 0.3363 & 140.8 & 1.6 & 7.31E-05 & 0.7 & 1.021 & 1.006 & 1.016 \\
\hline 19X-5W, 75-77 & 176.96 & 0.3269 & 112.5 & 74.0 & 0.3356 & 328.9 & 13.0 & 0.3375 & 236.7 & 9.2 & 7.62E-05 & 1.1 & 1.032 & 1.005 & 1.027 \\
\hline 19X-7W, 25-27 & 179.27 & 0.3295 & 147.0 & 85.8 & 0.3345 & 331.7 & 4.1 & 0.3360 & 241.7 & 0.3 & $6.91 \mathrm{E}-05$ & 0.6 & 1.020 & 1.004 & 1.015 \\
\hline $20 X-2 W, 81-83$ & 182.12 & 0.3271 & 203.4 & 68.2 & 0.3354 & 78.2 & 13.0 & 0.3375 & 344.1 & 17.2 & $7.24 \mathrm{E}-05$ & 1.0 & 1.032 & 1.006 & 1.025 \\
\hline 20X-4W, 77-79 & 185.08 & 0.3294 & 42.3 & 85.7 & 0.3352 & 308.5 & 0.3 & 0.3354 & 218.5 & 4.3 & 8.67E-05 & 0.6 & 1.018 & 1.001 & 1.018 \\
\hline
\end{tabular}


Table T15 (continued).

\begin{tabular}{|c|c|c|c|c|c|c|c|c|c|c|c|c|c|c|c|}
\hline \multirow{2}{*}{$\begin{array}{l}\text { Core, section, } \\
\text { interval }(\mathrm{cm})\end{array}$} & \multirow{2}{*}{$\begin{array}{l}\text { Depth } \\
\text { (mbsf) }\end{array}$} & \multirow[b]{2}{*}{$\tau_{3}$} & \multicolumn{2}{|c|}{$V_{3}\left({ }^{\circ}\right)$} & \multirow[b]{2}{*}{$\tau_{2}$} & \multicolumn{2}{|c|}{$V_{2}\left({ }^{\circ}\right)$} & \multirow[b]{2}{*}{$\tau_{1}$} & \multicolumn{2}{|c|}{$V_{1}\left({ }^{\circ}\right)$} & \multirow{2}{*}{$\begin{array}{c}\text { Bulk } \\
\text { susceptibility } \\
\text { (SI) }\end{array}$} & \multirow{2}{*}{$\begin{array}{l}\text { Anisotropy } \\
(\%)\end{array}$} & \multirow[b]{2}{*}{$P$} & \multirow[b]{2}{*}{$\mathrm{L}$} & \multirow[b]{2}{*}{$\mathrm{F}$} \\
\hline & & & Declinatio & nclination & & Declinatio & Inclination & & Declinatio & nclination & & & & & \\
\hline $20 X-6 W, 65-67$ & 187.96 & 0.3292 & 86.0 & 74.2 & 0.3349 & 237.9 & 14.0 & 0.3359 & 329.7 & 7.2 & 7.70E-05 & 0.7 & 1.020 & 1.003 & 1.017 \\
\hline $21 X-2 W, 77-79$ & 190.82 & 0.3293 & 159.9 & 69.1 & 0.3347 & 28.8 & 14.1 & 0.3360 & 294.9 & 15.1 & 8.77E-05 & 0.7 & 1.021 & 1.004 & 1.017 \\
\hline $21 X-4 W, 42-44$ & 193.43 & 0.3299 & 19.0 & 68.6 & 0.3343 & 131.2 & 8.4 & 0.3358 & 224.3 & 19.6 & $8.70 \mathrm{E}-05$ & 0.6 & 1.018 & 1.005 & 1.013 \\
\hline $21 X-6 W, 90-92$ & 196.78 & 0.3286 & 322.1 & 68.8 & 0.3337 & 186.5 & 15.5 & 0.3377 & 92.5 & 14.2 & $8.32 \mathrm{E}-05$ & 0.9 & 1.028 & 1.012 & 1.016 \\
\hline $22 \mathrm{X}-2 \mathrm{~W}, 76-78$ & 201.27 & 0.3293 & 149.4 & 74.1 & 0.3345 & 334.2 & 15.9 & 0.3362 & 243.8 & 1.3 & $9.30 \mathrm{E}-05$ & 0.7 & 1.021 & 1.005 & 1.016 \\
\hline $22 X-4 W, 67-69$ & 204.18 & 0.3292 & 332.9 & 82.7 & 0.3350 & 188.0 & 6.0 & 0.3358 & 97.5 & 4.2 & $8.72 \mathrm{E}-05$ & 0.7 & 1.020 & 1.002 & 1.018 \\
\hline $22 \mathrm{X}-6 \mathrm{~W}, 72-74$ & 207.23 & 0.3296 & 15.5 & 77.8 & 0.3344 & 245.1 & 8.0 & 0.3360 & 153.8 & 9.2 & $9.14 \mathrm{E}-05$ & 0.6 & 1.019 & 1.005 & 1.015 \\
\hline $23 \mathrm{X}-2 \mathrm{~W}, 109-111$ & 211.10 & 0.3308 & 84.8 & 3.4 & 0.3332 & 176.1 & 20.9 & 0.3361 & 346.1 & 68.8 & $8.24 \mathrm{E}-06$ & 0.5 & 1.016 & 1.009 & 1.007 \\
\hline $23 X-4 W, 93-95$ & 213.94 & 0.3303 & 136.6 & 64.6 & 0.3344 & 35.3 & 5.3 & 0.3352 & 302.8 & 24.7 & $6.01 \mathrm{E}-05$ & 0.5 & 1.015 & 1.002 & 1.012 \\
\hline $23 X-6 W, 92-94$ & 216.93 & 0.3313 & 208.6 & 68.4 & 0.3343 & 20.3 & 21.4 & 0.3344 & 111.4 & 2.9 & $6.56 \mathrm{E}-05$ & 0.3 & 1.009 & 1.001 & 1.009 \\
\hline $24 \mathrm{X}-4 \mathrm{~W}, 52-54$ & 223.03 & 0.3240 & 110.9 & 46.6 & 0.3374 & 16.1 & 4.5 & 0.3386 & 282.0 & 43.1 & $1.00 \mathrm{E}-05$ & 1.5 & 1.045 & 1.003 & 1.041 \\
\hline $24 \mathrm{X}-6 \mathrm{~W}, 97-99$ & 226.48 & 0.3151 & 354.4 & 38.8 & 0.3279 & 84.7 & 0.3 & 0.3570 & 175.1 & 51.2 & 4.47E-06 & 4.2 & 1.133 & 1.089 & 1.040 \\
\hline $25 X-4 W, 58-60$ & 232.59 & 0.3262 & 267.3 & 3.1 & 0.3347 & 160.0 & 79.6 & 0.3390 & 357.8 & 9.9 & $3.58 \mathrm{E}-06$ & 1.3 & 1.039 & 1.013 & 1.026 \\
\hline $26 X-4 W, 53-55$ & 242.14 & 0.3309 & 252.9 & 14.9 & 0.3335 & 344.9 & 7.4 & 0.3357 & 100.6 & 73.3 & $1.64 \mathrm{E}-05$ & 0.5 & 1.015 & 1.006 & 1.008 \\
\hline $26 \mathrm{X}-6 \mathrm{~W}, 77-79$ & 245.38 & 0.3304 & 359.6 & 85.5 & 0.3345 & 228.5 & 2.9 & 0.3351 & 138.3 & 3.4 & $1.03 \mathrm{E}-04$ & 0.5 & 1.014 & 1.002 & 1.012 \\
\hline $27 X-2 W, 54-56$ & 248.75 & 0.3315 & 292.1 & 72.6 & 0.3330 & 102.5 & 17.1 & 0.3356 & 193.3 & 2.8 & $3.01 \mathrm{E}-05$ & 0.4 & 1.012 & 1.008 & 1.005 \\
\hline $27 X-4 W, 93-95$ & 252.14 & 0.3301 & 25.5 & 79.4 & 0.3346 & 211.5 & 10.6 & 0.3353 & 121.3 & 1.1 & $2.87 \mathrm{E}-05$ & 0.5 & 1.016 & 1.002 & 1.014 \\
\hline $28 \mathrm{X}-2 \mathrm{~W}, 41-43$ & 258.22 & 0.3309 & 103.3 & 87.3 & 0.3339 & 249.0 & 2.2 & 0.3352 & 339.0 & 1.5 & $3.40 \mathrm{E}-05$ & 0.4 & 1.013 & 1.004 & 1.009 \\
\hline
\end{tabular}

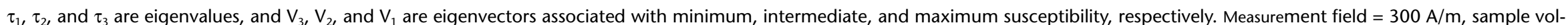
$\tau_{1}, \tau_{2}$, and $\tau_{3}$ are eigenvalues, and $V_{3}, V_{2}$, and $V_{1}$ are eigenvectors
ume $=7 \mathrm{~cm}^{3} . P=$ anisotropy degree, $L=$ lineation, $F=$ foliation 


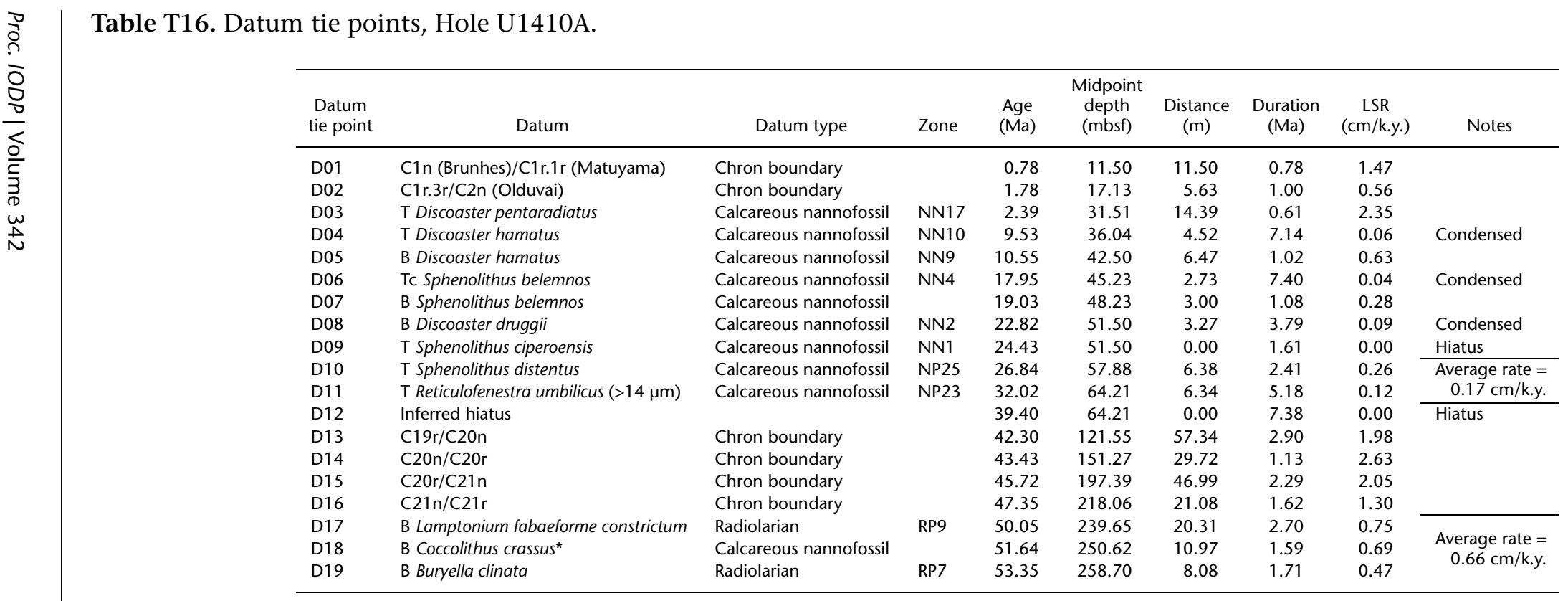

* = From Agnini et. al. (2007) recalibrated to GTS2012. LSR = linear sedimentation rate. $T=$ top, $T C=$ top common, B = base. 
Table T17. Carbonate content and accumulation rates, Site U1410. (Continued on next three pages.)

\begin{tabular}{|c|c|c|c|c|c|c|}
\hline $\begin{array}{l}\text { Age } \\
(\mathrm{Ma})\end{array}$ & $\begin{array}{c}\text { LSR } \\
(\mathrm{cm} / \mathrm{k} . \mathrm{y} .)\end{array}$ & $\begin{array}{l}\text { Dry density } \\
\left(\mathrm{g} / \mathrm{cm}^{3}\right)\end{array}$ & $\begin{array}{l}\mathrm{CaCO}_{3} \\
(\mathrm{wt} \%)\end{array}$ & $\begin{array}{c}\text { MAR } \\
\left(\mathrm{g} / \mathrm{cm}^{2} / \mathrm{k} . \mathrm{y} .\right)\end{array}$ & $\begin{array}{c}\text { CAR } \\
\left(\mathrm{g} / \mathrm{cm}^{2} / \mathrm{k} . \mathrm{y} .\right)\end{array}$ & $\begin{array}{c}\mathrm{nCAR} \\
\left(\mathrm{g} / \mathrm{cm}^{2} / \mathrm{k} \cdot \mathrm{y} .\right)\end{array}$ \\
\hline 0.2 & 1.47 & 0.96 & 33.17 & 1.41 & 0.47 & 0.95 \\
\hline 0.4 & 1.47 & 0.89 & 34.19 & 1.31 & 0.45 & 0.86 \\
\hline 0.6 & 1.47 & 1.26 & 49.29 & 1.86 & 0.92 & 0.94 \\
\hline 0.8 & 0.56 & 1.04 & 48.22 & 0.59 & 0.28 & 0.30 \\
\hline 1.0 & 0.56 & 1.02 & 54.70 & 0.58 & 0.31 & 0.26 \\
\hline 1.2 & 0.56 & 0.93 & 43.72 & 0.53 & 0.23 & 0.30 \\
\hline 1.4 & 0.56 & 0.82 & 14.87 & 0.46 & 0.07 & 0.40 \\
\hline 1.6 & 0.56 & 0.85 & 30.09 & 0.48 & 0.14 & 0.34 \\
\hline 1.8 & 2.35 & 0.93 & 46.04 & 2.19 & 1.01 & 1.18 \\
\hline 2.0 & 2.35 & 0.91 & 43.08 & 2.14 & 0.92 & 1.22 \\
\hline 2.2 & 2.35 & 0.99 & 27.43 & 2.33 & 0.64 & 1.69 \\
\hline 2.4 & 0.06 & 1.06 & 14.81 & 0.07 & 0.01 & 0.06 \\
\hline 2.6 & 0.06 & 1.06 & 12.86 & 0.07 & 0.01 & 0.06 \\
\hline 2.8 & 0.06 & 1.05 & 12.54 & 0.07 & 0.01 & 0.06 \\
\hline 3.0 & 0.06 & 1.04 & 12.22 & 0.07 & 0.01 & 0.06 \\
\hline 3.2 & 0.06 & 1.03 & 11.90 & 0.07 & 0.01 & 0.06 \\
\hline 3.4 & 0.06 & 1.02 & 11.58 & 0.06 & 0.01 & 0.06 \\
\hline 3.6 & 0.06 & 1.01 & 11.26 & 0.06 & 0.01 & 0.06 \\
\hline 3.8 & 0.06 & 1.01 & 10.93 & 0.06 & 0.01 & 0.06 \\
\hline 4.0 & 0.06 & 1.02 & 10.59 & 0.07 & 0.01 & 0.06 \\
\hline 4.2 & 0.06 & 1.03 & 10.25 & 0.07 & 0.01 & 0.06 \\
\hline 4.4 & 0.06 & 1.05 & 9.90 & 0.07 & 0.01 & 0.06 \\
\hline 4.6 & 0.06 & 1.06 & 9.56 & 0.07 & 0.01 & 0.06 \\
\hline 4.8 & 0.06 & 1.08 & 9.22 & 0.07 & 0.01 & 0.06 \\
\hline 5.0 & 0.06 & 1.09 & 8.88 & 0.07 & 0.01 & 0.06 \\
\hline 5.2 & 0.06 & 1.11 & 8.54 & 0.07 & 0.01 & 0.06 \\
\hline 5.4 & 0.06 & 1.12 & 8.20 & 0.07 & 0.01 & 0.07 \\
\hline 5.6 & 0.06 & 1.14 & 7.86 & 0.07 & 0.01 & 0.07 \\
\hline 5.8 & 0.06 & 1.15 & 7.51 & 0.07 & 0.01 & 0.07 \\
\hline 6.0 & 0.06 & 1.16 & 7.17 & 0.07 & 0.01 & 0.07 \\
\hline 6.2 & 0.06 & 1.17 & 6.84 & 0.07 & 0.01 & 0.07 \\
\hline 6.4 & 0.06 & 1.14 & 6.54 & 0.07 & 0.01 & 0.07 \\
\hline 6.6 & 0.06 & 1.12 & 6.23 & 0.07 & 0.00 & 0.07 \\
\hline 6.8 & 0.06 & 1.10 & 5.93 & 0.07 & 0.00 & 0.07 \\
\hline 7.0 & 0.06 & 1.07 & 5.63 & 0.07 & 0.00 & 0.06 \\
\hline 7.2 & 0.06 & 1.05 & 5.32 & 0.07 & 0.00 & 0.06 \\
\hline 7.4 & 0.06 & 1.03 & 5.02 & 0.07 & 0.00 & 0.06 \\
\hline 7.6 & 0.06 & 1.00 & 4.71 & 0.06 & 0.00 & 0.06 \\
\hline 7.8 & 0.06 & 0.98 & 4.41 & 0.06 & 0.00 & 0.06 \\
\hline 8.0 & 0.06 & 0.95 & 4.10 & 0.06 & 0.00 & 0.06 \\
\hline 8.2 & 0.06 & 0.93 & 3.80 & 0.06 & 0.00 & 0.06 \\
\hline 8.4 & 0.06 & 0.91 & 3.49 & 0.06 & 0.00 & 0.06 \\
\hline 8.6 & 0.06 & 0.89 & 4.21 & 0.06 & 0.00 & 0.05 \\
\hline 8.8 & 0.06 & 0.89 & 5.88 & 0.06 & 0.00 & 0.05 \\
\hline 9.0 & 0.06 & 0.88 & 7.54 & 0.06 & 0.00 & 0.05 \\
\hline 9.2 & 0.06 & 0.88 & 9.21 & 0.06 & 0.01 & 0.05 \\
\hline 9.4 & 0.06 & 0.87 & 10.88 & 0.06 & 0.01 & 0.05 \\
\hline 9.6 & 0.63 & 0.87 & 11.97 & 0.55 & 0.07 & 0.48 \\
\hline 9.8 & 0.63 & 0.86 & 8.48 & 0.54 & 0.05 & 0.50 \\
\hline 10.0 & 0.63 & 0.91 & 12.68 & 0.57 & 0.07 & 0.50 \\
\hline 10.2 & 0.63 & 0.94 & 16.00 & 0.60 & 0.10 & 0.50 \\
\hline 10.4 & 0.63 & 0.91 & 7.37 & 0.58 & 0.04 & 0.54 \\
\hline 10.6 & 0.04 & 0.90 & 3.80 & 0.03 & 0.00 & 0.03 \\
\hline 10.8 & 0.04 & 0.90 & 3.54 & 0.03 & 0.00 & 0.03 \\
\hline 11.0 & 0.04 & 0.90 & 3.27 & 0.03 & 0.00 & 0.03 \\
\hline 11.2 & 0.04 & 0.90 & 3.00 & 0.03 & 0.00 & 0.03 \\
\hline 11.4 & 0.04 & 0.90 & 2.74 & 0.03 & 0.00 & 0.03 \\
\hline 11.6 & 0.04 & 0.90 & 2.47 & 0.03 & 0.00 & 0.03 \\
\hline 11.8 & 0.04 & 0.90 & 2.21 & 0.03 & 0.00 & 0.03 \\
\hline 12.0 & 0.04 & 0.90 & 1.94 & 0.03 & 0.00 & 0.03 \\
\hline 12.2 & 0.04 & 0.90 & 1.67 & 0.03 & 0.00 & 0.03 \\
\hline 12.4 & 0.04 & 0.90 & 1.41 & 0.03 & 0.00 & 0.03 \\
\hline 12.6 & 0.04 & 0.90 & 1.14 & 0.03 & 0.00 & 0.03 \\
\hline 12.8 & 0.04 & 0.90 & 0.88 & 0.03 & 0.00 & 0.03 \\
\hline 13.0 & 0.04 & 0.90 & 0.99 & 0.03 & 0.00 & 0.03 \\
\hline 13.2 & 0.04 & 0.91 & 1.88 & 0.03 & 0.00 & 0.03 \\
\hline 13.4 & 0.04 & 0.91 & 2.79 & 0.03 & 0.00 & 0.03 \\
\hline 13.6 & 0.04 & 0.91 & 3.70 & 0.03 & 0.00 & 0.03 \\
\hline 13.8 & 0.04 & 0.91 & 4.62 & 0.03 & 0.00 & 0.03 \\
\hline
\end{tabular}


Table T17 (continued). (Continued on next page.)

\begin{tabular}{|c|c|c|c|c|c|c|}
\hline $\begin{array}{l}\text { Age } \\
(\mathrm{Ma})\end{array}$ & $\begin{array}{c}\text { LSR } \\
\text { (cm/k.y.) }\end{array}$ & $\begin{array}{l}\text { Dry density } \\
\left(\mathrm{g} / \mathrm{cm}^{3}\right)\end{array}$ & $\begin{array}{c}\mathrm{CaCO}_{3} \\
\text { (wt\%) }\end{array}$ & $\begin{array}{c}\text { MAR } \\
\left(\mathrm{g} / \mathrm{cm}^{2} / \mathrm{k} . \mathrm{y} .\right)\end{array}$ & $\begin{array}{c}\text { CAR } \\
\left(\mathrm{g} / \mathrm{cm}^{2} / \mathrm{k} . \mathrm{y} .\right)\end{array}$ & $\begin{array}{c}\text { nCAR } \\
\left(\mathrm{g} / \mathrm{cm}^{2} / \mathrm{k} . \mathrm{y} .\right)\end{array}$ \\
\hline 14.0 & 0.04 & 0.91 & 5.53 & 0.03 & 0.00 & 0.03 \\
\hline 14.2 & 0.04 & 0.92 & 6.44 & 0.03 & 0.00 & 0.03 \\
\hline 14.4 & 0.04 & 0.92 & 7.35 & 0.03 & 0.00 & 0.03 \\
\hline 14.6 & 0.04 & 0.92 & 8.27 & 0.03 & 0.00 & 0.03 \\
\hline 14.8 & 0.04 & 0.92 & 9.18 & 0.03 & 0.00 & 0.03 \\
\hline 15.0 & 0.04 & 0.92 & 10.09 & 0.03 & 0.00 & 0.03 \\
\hline 15.2 & 0.04 & 0.93 & 11.00 & 0.03 & 0.00 & 0.03 \\
\hline 15.4 & 0.04 & 0.93 & 11.91 & 0.03 & 0.00 & 0.03 \\
\hline 15.6 & 0.04 & 0.93 & 12.83 & 0.03 & 0.00 & 0.03 \\
\hline 15.8 & 0.04 & 0.93 & 13.74 & 0.03 & 0.01 & 0.03 \\
\hline 16.0 & 0.04 & 0.93 & 14.65 & 0.03 & 0.01 & 0.03 \\
\hline 16.2 & 0.04 & 0.93 & 15.56 & 0.03 & 0.01 & 0.03 \\
\hline 16.4 & 0.04 & 0.94 & 16.48 & 0.03 & 0.01 & 0.03 \\
\hline 16.6 & 0.04 & 0.94 & 17.37 & 0.04 & 0.01 & 0.03 \\
\hline 16.8 & 0.04 & 0.94 & 17.69 & 0.03 & 0.01 & 0.03 \\
\hline 17.0 & 0.04 & 0.93 & 17.72 & 0.03 & 0.01 & 0.03 \\
\hline 17.2 & 0.04 & 0.93 & 17.76 & 0.03 & 0.01 & 0.03 \\
\hline 17.4 & 0.04 & 0.92 & 17.80 & 0.03 & 0.01 & 0.03 \\
\hline 17.6 & 0.04 & 0.92 & 17.83 & 0.03 & 0.01 & 0.03 \\
\hline 17.8 & 0.04 & 0.91 & 17.87 & 0.03 & 0.01 & 0.03 \\
\hline 18.0 & 0.28 & 0.91 & 17.90 & 0.25 & 0.05 & 0.21 \\
\hline 18.2 & 0.28 & 0.89 & 17.66 & 0.25 & 0.04 & 0.20 \\
\hline 18.4 & 0.28 & 0.85 & 16.87 & 0.24 & 0.04 & 0.20 \\
\hline 18.6 & 0.28 & 0.81 & 15.46 & 0.23 & 0.04 & 0.19 \\
\hline 18.8 & 0.28 & 0.78 & 12.64 & 0.22 & 0.03 & 0.19 \\
\hline 19.0 & 0.28 & 0.74 & 9.77 & 0.21 & 0.02 & 0.19 \\
\hline 19.2 & 0.09 & 0.71 & 7.25 & 0.06 & 0.00 & 0.06 \\
\hline 19.4 & 0.09 & 0.72 & 7.32 & 0.06 & 0.01 & 0.06 \\
\hline 19.6 & 0.09 & 0.73 & 7.91 & 0.06 & 0.01 & 0.06 \\
\hline 19.8 & 0.09 & 0.75 & 8.50 & 0.06 & 0.01 & 0.06 \\
\hline 20.0 & 0.09 & 0.76 & 9.08 & 0.07 & 0.01 & 0.06 \\
\hline 20.2 & 0.09 & 0.77 & 9.67 & 0.07 & 0.01 & 0.06 \\
\hline 20.4 & 0.09 & 0.79 & 10.26 & 0.07 & 0.01 & 0.06 \\
\hline 20.6 & 0.09 & 0.80 & 10.84 & 0.07 & 0.01 & 0.06 \\
\hline 20.8 & 0.09 & 0.81 & 11.43 & 0.07 & 0.01 & 0.06 \\
\hline 21.0 & 0.09 & 0.82 & 11.53 & 0.07 & 0.01 & 0.06 \\
\hline 21.2 & 0.09 & 0.82 & 10.52 & 0.07 & 0.01 & 0.06 \\
\hline 21.4 & 0.09 & 0.82 & 9.47 & 0.07 & 0.01 & 0.06 \\
\hline 21.6 & 0.09 & 0.81 & 8.42 & 0.07 & 0.01 & 0.06 \\
\hline 21.8 & 0.09 & 0.81 & 7.37 & 0.07 & 0.01 & 0.07 \\
\hline 22.0 & 0.09 & 0.80 & 6.32 & 0.07 & 0.00 & 0.07 \\
\hline 22.2 & 0.09 & 0.80 & 5.27 & 0.07 & 0.00 & 0.07 \\
\hline 22.4 & 0.09 & 0.79 & 4.22 & 0.07 & 0.00 & 0.07 \\
\hline 22.6 & 0.09 & 0.79 & 3.17 & 0.07 & 0.00 & 0.07 \\
\hline 22.8 & 0.09 & 0.79 & 2.96 & 0.07 & 0.00 & 0.07 \\
\hline 23.0 & 0.00 & 0.81 & 3.32 & 0.00 & 0.00 & 0.00 \\
\hline 23.2 & 0.00 & 0.82 & 3.69 & 0.00 & 0.00 & 0.00 \\
\hline 23.4 & 0.00 & 0.83 & 4.06 & 0.00 & 0.00 & 0.00 \\
\hline 23.6 & 0.00 & 0.85 & 4.43 & 0.00 & 0.00 & 0.00 \\
\hline 23.8 & 0.00 & 0.86 & 4.79 & 0.00 & 0.00 & 0.00 \\
\hline 24.0 & 0.00 & 0.87 & 5.16 & 0.00 & 0.00 & 0.00 \\
\hline 24.2 & 0.00 & 0.88 & 5.53 & 0.00 & 0.00 & 0.00 \\
\hline 24.4 & 0.00 & 0.90 & 5.90 & 0.00 & 0.00 & 0.00 \\
\hline 24.6 & 0.27 & 0.91 & 6.26 & 0.24 & 0.02 & 0.23 \\
\hline 24.8 & 0.27 & 0.92 & 6.63 & 0.24 & 0.02 & 0.23 \\
\hline 25.0 & 0.27 & 0.94 & 6.80 & 0.25 & 0.02 & 0.23 \\
\hline 25.2 & 0.27 & 0.95 & 6.47 & 0.25 & 0.02 & 0.24 \\
\hline 25.4 & 0.27 & 0.96 & 6.11 & 0.25 & 0.02 & 0.24 \\
\hline 25.6 & 0.27 & 0.96 & 6.30 & 0.25 & 0.02 & 0.24 \\
\hline 25.8 & 0.27 & 0.93 & 7.27 & 0.25 & 0.02 & 0.23 \\
\hline 26.0 & 0.27 & 0.91 & 8.69 & 0.24 & 0.02 & 0.22 \\
\hline 26.2 & 0.27 & 0.91 & 11.60 & 0.24 & 0.03 & 0.21 \\
\hline 26.4 & 0.27 & 0.94 & 11.81 & 0.25 & 0.03 & 0.22 \\
\hline 26.6 & 0.27 & 1.00 & 10.24 & 0.26 & 0.03 & 0.24 \\
\hline 26.8 & 0.27 & 1.05 & 8.75 & 0.28 & 0.02 & 0.25 \\
\hline 27.0 & 0.12 & 1.07 & 10.07 & 0.13 & 0.01 & 0.12 \\
\hline 27.2 & 0.12 & 1.06 & 12.75 & 0.13 & 0.02 & 0.11 \\
\hline 27.4 & 0.12 & 1.04 & 15.44 & 0.13 & 0.02 & 0.11 \\
\hline 27.6 & 0.12 & 1.03 & 18.12 & 0.13 & 0.02 & 0.10 \\
\hline
\end{tabular}


Table T17 (continued). (Continued on next page.)

\begin{tabular}{|c|c|c|c|c|c|c|}
\hline $\begin{array}{l}\text { Age } \\
(\mathrm{Ma})\end{array}$ & $\begin{array}{c}\text { LSR } \\
\text { (cm/k.y.) }\end{array}$ & $\begin{array}{l}\text { Dry density } \\
\left(\mathrm{g} / \mathrm{cm}^{3}\right)\end{array}$ & $\begin{array}{c}\mathrm{CaCO}_{3} \\
\text { (wt\%) }\end{array}$ & $\begin{array}{c}\text { MAR } \\
\left(\mathrm{g} / \mathrm{cm}^{2} / \mathrm{k} . \mathrm{y} .\right)\end{array}$ & $\begin{array}{c}\text { CAR } \\
\left(\mathrm{g} / \mathrm{cm}^{2} / \mathrm{k} \cdot \mathrm{y} .\right)\end{array}$ & $\begin{array}{c}\mathrm{nCAR} \\
\left(\mathrm{g} / \mathrm{cm}^{2} / \mathrm{k} . \mathrm{y} .\right)\end{array}$ \\
\hline 27.8 & 0.12 & 1.02 & 20.81 & 0.13 & 0.03 & 0.10 \\
\hline 28.0 & 0.12 & 1.02 & 21.33 & 0.13 & 0.03 & 0.10 \\
\hline 28.2 & 0.12 & 1.04 & 18.49 & 0.13 & 0.02 & 0.10 \\
\hline 28.4 & 0.12 & 1.05 & 15.61 & 0.13 & 0.02 & 0.11 \\
\hline 28.6 & 0.12 & 1.07 & 13.72 & 0.13 & 0.02 & 0.11 \\
\hline 28.8 & 0.12 & 1.07 & 14.38 & 0.13 & 0.02 & 0.11 \\
\hline 29.0 & 0.12 & 1.08 & 15.17 & 0.13 & 0.02 & 0.11 \\
\hline 29.2 & 0.12 & 1.08 & 15.96 & 0.13 & 0.02 & 0.11 \\
\hline 29.4 & 0.12 & 1.09 & 16.75 & 0.13 & 0.02 & 0.11 \\
\hline 29.6 & 0.12 & 1.09 & 17.34 & 0.13 & 0.02 & 0.11 \\
\hline 29.8 & 0.12 & 1.09 & 17.46 & 0.13 & 0.02 & 0.11 \\
\hline 30.0 & 0.12 & 1.08 & 17.56 & 0.13 & 0.02 & 0.11 \\
\hline 30.2 & 0.12 & 1.08 & 17.65 & 0.13 & 0.02 & 0.11 \\
\hline 30.4 & 0.12 & 1.07 & 17.74 & 0.13 & 0.02 & 0.11 \\
\hline 30.6 & 0.12 & 1.07 & 16.50 & 0.13 & 0.02 & 0.11 \\
\hline 30.8 & 0.12 & 1.07 & 14.30 & 0.13 & 0.02 & 0.11 \\
\hline 31.0 & 0.12 & 1.07 & 12.10 & 0.13 & 0.02 & 0.12 \\
\hline 31.2 & 0.12 & 1.07 & 9.91 & 0.13 & 0.01 & 0.12 \\
\hline 31.4 & 0.12 & 1.06 & 7.71 & 0.13 & 0.01 & 0.12 \\
\hline 31.6 & 0.12 & 1.06 & 5.51 & 0.13 & 0.01 & 0.12 \\
\hline 31.8 & 0.12 & 1.06 & 3.77 & 0.13 & 0.01 & 0.13 \\
\hline 32.0 & 0.12 & 1.06 & 4.33 & 0.13 & 0.01 & 0.12 \\
\hline 32.2 & 0.00 & 1.06 & 5.21 & 0.00 & 0.00 & 0.00 \\
\hline 32.4 & 0.00 & 1.06 & 6.08 & 0.00 & 0.00 & 0.00 \\
\hline 32.6 & 0.00 & 1.06 & 6.96 & 0.00 & 0.00 & 0.00 \\
\hline 32.8 & 0.00 & 1.05 & 7.84 & 0.00 & 0.00 & 0.00 \\
\hline 33.0 & 0.00 & 1.05 & 8.72 & 0.00 & 0.00 & 0.00 \\
\hline 33.2 & 0.00 & 1.05 & 9.59 & 0.00 & 0.00 & 0.00 \\
\hline 33.4 & 0.00 & 1.05 & 10.47 & 0.00 & 0.00 & 0.00 \\
\hline 33.6 & 0.00 & 1.05 & 11.35 & 0.00 & 0.00 & 0.00 \\
\hline 33.8 & 0.00 & 1.05 & 12.23 & 0.00 & 0.00 & 0.00 \\
\hline 34.0 & 0.00 & 1.04 & 13.10 & 0.00 & 0.00 & 0.00 \\
\hline 34.2 & 0.00 & 1.04 & 13.98 & 0.00 & 0.00 & 0.00 \\
\hline 34.4 & 0.00 & 1.04 & 14.86 & 0.00 & 0.00 & 0.00 \\
\hline 34.6 & 0.00 & 1.04 & 15.74 & 0.00 & 0.00 & 0.00 \\
\hline 34.8 & 0.00 & 1.04 & 16.61 & 0.00 & 0.00 & 0.00 \\
\hline 35.0 & 0.00 & 1.04 & 17.49 & 0.00 & 0.00 & 0.00 \\
\hline 35.2 & 0.00 & 1.03 & 18.37 & 0.00 & 0.00 & 0.00 \\
\hline 35.4 & 0.00 & 1.03 & 19.24 & 0.00 & 0.00 & 0.00 \\
\hline 35.6 & 0.00 & 1.03 & 20.12 & 0.00 & 0.00 & 0.00 \\
\hline 35.8 & 0.00 & 1.03 & 21.00 & 0.00 & 0.00 & 0.00 \\
\hline 36.0 & 0.00 & 1.03 & 21.88 & 0.00 & 0.00 & 0.00 \\
\hline 36.2 & 0.00 & 1.02 & 22.75 & 0.00 & 0.00 & 0.00 \\
\hline 36.4 & 0.00 & 1.02 & 23.63 & 0.00 & 0.00 & 0.00 \\
\hline 36.6 & 0.00 & 1.02 & 24.51 & 0.00 & 0.00 & 0.00 \\
\hline 36.8 & 0.00 & 1.02 & 25.39 & 0.00 & 0.00 & 0.00 \\
\hline 37.0 & 0.00 & 1.02 & 26.26 & 0.00 & 0.00 & 0.00 \\
\hline 37.2 & 0.00 & 1.02 & 27.14 & 0.00 & 0.00 & 0.00 \\
\hline 37.4 & 0.00 & 1.01 & 28.02 & 0.00 & 0.00 & 0.00 \\
\hline 37.6 & 0.00 & 1.01 & 28.89 & 0.00 & 0.00 & 0.00 \\
\hline 37.8 & 0.00 & 1.01 & 29.77 & 0.00 & 0.00 & 0.00 \\
\hline 38.0 & 0.00 & 1.01 & 30.65 & 0.00 & 0.00 & 0.00 \\
\hline 38.2 & 0.00 & 1.01 & 31.53 & 0.00 & 0.00 & 0.00 \\
\hline 38.4 & 0.00 & 1.01 & 32.40 & 0.00 & 0.00 & 0.00 \\
\hline 38.6 & 0.00 & 1.00 & 33.28 & 0.00 & 0.00 & 0.00 \\
\hline 38.8 & 0.00 & 1.00 & 34.16 & 0.00 & 0.00 & 0.00 \\
\hline 39.0 & 0.00 & 1.00 & 35.04 & 0.00 & 0.00 & 0.00 \\
\hline 39.2 & 0.00 & 1.00 & 35.91 & 0.00 & 0.00 & 0.00 \\
\hline 39.4 & 1.98 & 1.00 & 36.78 & 1.97 & 0.72 & 1.25 \\
\hline 39.6 & 1.98 & 1.00 & 41.14 & 1.98 & 0.81 & 1.16 \\
\hline 39.8 & 1.98 & 1.01 & 43.63 & 1.99 & 0.87 & 1.12 \\
\hline 40.0 & 1.98 & 1.00 & 41.75 & 1.97 & 0.82 & 1.15 \\
\hline 40.2 & 1.98 & 0.98 & 48.30 & 1.93 & 0.93 & 1.00 \\
\hline 40.4 & 1.98 & 1.04 & 29.72 & 2.05 & 0.61 & 1.44 \\
\hline 40.6 & 1.98 & 1.07 & 35.45 & 2.12 & 0.75 & 1.37 \\
\hline 40.8 & 1.98 & 1.06 & 49.33 & 2.09 & 1.03 & 1.06 \\
\hline 41.0 & 1.98 & 1.07 & 45.44 & 2.11 & 0.96 & 1.15 \\
\hline 41.2 & 1.98 & 1.03 & 57.47 & 2.03 & 1.17 & 0.87 \\
\hline 41.4 & 1.98 & 1.05 & 45.63 & 2.07 & 0.94 & 1.12 \\
\hline
\end{tabular}


Table T17 (continued).

\begin{tabular}{|c|c|c|c|c|c|c|}
\hline $\begin{array}{l}\text { Age } \\
(\mathrm{Ma})\end{array}$ & $\begin{array}{c}\text { LSR } \\
\text { (cm/k.y.) }\end{array}$ & $\begin{array}{l}\text { Dry density } \\
\left(\mathrm{g} / \mathrm{cm}^{3}\right)\end{array}$ & $\begin{array}{l}\mathrm{CaCO}_{3} \\
\text { (wt\%) }\end{array}$ & $\begin{array}{c}\text { MAR } \\
\left(\mathrm{g} / \mathrm{cm}^{2} / \mathrm{k} . \mathrm{y} .\right)\end{array}$ & $\begin{array}{c}\text { CAR } \\
\left(\mathrm{g} / \mathrm{cm}^{2} / \mathrm{k} . \mathrm{y} .\right)\end{array}$ & $\begin{array}{c}\text { nCAR } \\
\left(\mathrm{g} / \mathrm{cm}^{2} / \mathrm{k} . \mathrm{y} .\right)\end{array}$ \\
\hline 41.6 & 1.98 & 1.03 & 58.75 & 2.03 & 1.19 & 0.84 \\
\hline 41.8 & 1.98 & 1.03 & 49.40 & 2.04 & 1.01 & 1.03 \\
\hline 42.0 & 1.98 & 1.08 & 35.56 & 2.14 & 0.76 & 1.38 \\
\hline 42.2 & 1.98 & 1.11 & 37.31 & 2.19 & 0.82 & 1.37 \\
\hline 42.4 & 2.63 & 1.04 & 31.07 & 2.74 & 0.85 & 1.89 \\
\hline 42.6 & 2.63 & 1.07 & 38.34 & 2.80 & 1.07 & 1.73 \\
\hline 42.8 & 2.63 & 1.04 & 52.77 & 2.74 & 1.45 & 1.30 \\
\hline 43.0 & 2.63 & 1.05 & 43.08 & 2.77 & 1.20 & 1.58 \\
\hline 43.2 & 2.63 & 1.09 & 37.39 & 2.86 & 1.07 & 1.79 \\
\hline 43.4 & 2.63 & 1.05 & 41.78 & 2.76 & 1.15 & 1.61 \\
\hline 43.6 & 2.05 & 1.00 & 46.74 & 2.04 & 0.96 & 1.09 \\
\hline 43.8 & 2.05 & 1.03 & 53.36 & 2.11 & 1.13 & 0.98 \\
\hline 44.0 & 2.05 & 0.95 & 41.64 & 1.95 & 0.81 & 1.14 \\
\hline 44.2 & 2.05 & 0.98 & 47.71 & 2.00 & 0.96 & 1.05 \\
\hline 44.4 & 2.05 & 1.01 & 45.66 & 2.07 & 0.94 & 1.12 \\
\hline 44.6 & 2.05 & 1.03 & 38.76 & 2.10 & 0.82 & 1.29 \\
\hline 44.8 & 2.05 & 1.09 & 47.18 & 2.23 & 1.05 & 1.18 \\
\hline 45.0 & 2.05 & 1.22 & 43.86 & 2.50 & 1.10 & 1.41 \\
\hline 45.2 & 2.05 & 1.20 & 44.52 & 2.45 & 1.09 & 1.36 \\
\hline 45.4 & 2.05 & 1.21 & 42.40 & 2.49 & 1.06 & 1.43 \\
\hline 45.6 & 2.05 & 1.23 & 48.03 & 2.52 & 1.21 & 1.31 \\
\hline 45.8 & 1.29 & 1.23 & 47.40 & 1.60 & 0.76 & 0.84 \\
\hline 46.0 & 1.29 & 1.23 & 44.86 & 1.60 & 0.72 & 0.88 \\
\hline 46.2 & 1.29 & 1.29 & 47.66 & 1.67 & 0.79 & 0.87 \\
\hline 46.4 & 1.29 & 1.29 & 40.90 & 1.68 & 0.69 & 0.99 \\
\hline 46.6 & 1.29 & 1.37 & 67.67 & 1.77 & 1.20 & 0.57 \\
\hline 46.8 & 1.29 & 1.33 & 89.11 & 1.73 & 1.54 & 0.19 \\
\hline 47.0 & 1.29 & 1.30 & 85.37 & 1.68 & 1.44 & 0.25 \\
\hline 47.2 & 1.29 & 1.23 & 84.89 & 1.59 & 1.35 & 0.24 \\
\hline 47.4 & 0.75 & 1.16 & 87.51 & 0.87 & 0.76 & 0.11 \\
\hline 47.6 & 0.75 & 1.18 & 84.77 & 0.89 & 0.76 & 0.14 \\
\hline 47.8 & 0.75 & 1.20 & 83.14 & 0.90 & 0.75 & 0.15 \\
\hline 48.0 & 0.75 & 1.31 & 84.77 & 0.99 & 0.84 & 0.15 \\
\hline 48.2 & 0.75 & 1.48 & 87.15 & 1.11 & 0.97 & 0.14 \\
\hline 48.4 & 0.75 & 1.32 & 87.79 & 0.99 & 0.87 & 0.12 \\
\hline 48.6 & 0.75 & 1.21 & 88.44 & 0.91 & 0.80 & 0.11 \\
\hline 48.8 & 0.75 & 1.18 & 87.66 & 0.89 & 0.78 & 0.11 \\
\hline 49.0 & 0.75 & 1.15 & 86.58 & 0.87 & 0.75 & 0.12 \\
\hline 49.2 & 0.75 & 1.16 & 86.04 & 0.87 & 0.75 & 0.12 \\
\hline 49.4 & 0.75 & 1.19 & 85.53 & 0.89 & 0.76 & 0.13 \\
\hline 49.6 & 0.75 & 1.22 & 85.03 & 0.92 & 0.78 & 0.14 \\
\hline 49.8 & 0.75 & 1.26 & 84.94 & 0.95 & 0.81 & 0.14 \\
\hline 50.0 & 0.75 & 1.27 & 85.50 & 0.96 & 0.82 & 0.14 \\
\hline 50.2 & 0.69 & 1.16 & 86.46 & 0.80 & 0.69 & 0.11 \\
\hline 50.4 & 0.69 & 1.21 & 88.30 & 0.84 & 0.74 & 0.10 \\
\hline 50.6 & 0.69 & 1.20 & 86.02 & 0.83 & 0.71 & 0.12 \\
\hline 50.8 & 0.69 & 1.39 & 90.49 & 0.95 & 0.86 & 0.09 \\
\hline 51.0 & 0.69 & 1.38 & 90.66 & 0.95 & 0.86 & 0.09 \\
\hline 51.2 & 0.69 & 1.37 & 89.95 & 0.95 & 0.85 & 0.10 \\
\hline 51.4 & 0.69 & 1.44 & 90.71 & 0.99 & 0.90 & 0.09 \\
\hline 51.6 & 0.69 & 1.43 & 91.89 & 0.99 & 0.91 & 0.08 \\
\hline 51.8 & 0.47 & 1.53 & 90.50 & 0.72 & 0.65 & 0.07 \\
\hline 52.0 & 0.47 & 1.58 & 89.52 & 0.75 & 0.67 & 0.08 \\
\hline 52.2 & 0.47 & 1.45 & 90.58 & 0.69 & 0.62 & 0.07 \\
\hline 52.4 & 0.47 & 1.37 & 90.52 & 0.65 & 0.59 & 0.06 \\
\hline 52.6 & 0.47 & 1.36 & 90.68 & 0.64 & 0.58 & 0.06 \\
\hline 52.8 & 0.47 & 1.36 & 91.24 & 0.65 & 0.59 & 0.06 \\
\hline 53.0 & 0.47 & & 90.55 & 0.00 & 0.00 & 0.00 \\
\hline
\end{tabular}

$\mathrm{LSR}=$ linear sedimentation rate, $\mathrm{MAR}=$ mass accumulation rate, $\mathrm{CAR}=$ carbonate accumulation rate, $\mathrm{nCAR}=$ noncarbonate accumulation rate 
Table T18. Geochemistry of headspace gas samples, Hole U1410A.

\begin{tabular}{lrr}
\hline $\begin{array}{c}\text { Core, section, } \\
\text { interval (cm) }\end{array}$ & $\begin{array}{r}\text { Depth } \\
\text { (mbsf) }\end{array}$ & $\begin{array}{r}\text { Methane } \\
\text { (ppmv) }\end{array}$ \\
\hline $342-\mathrm{H} 1410-$ & & \\
1H-6, 0-5 & 7.50 & 2.11 \\
$2 \mathrm{H}-7,0-5$ & 17.50 & 2.20 \\
$3 \mathrm{H}-7,0-5$ & 27.00 & 2.26 \\
$4 \mathrm{H}-7,0-5$ & 36.50 & 2.78 \\
$5 \mathrm{H}-7,0-5$ & 45.61 & 2.71 \\
$6 \mathrm{H}-7,0-5$ & 55.41 & 2.89 \\
$7 \mathrm{H}-7,0-5$ & 63.55 & 2.77 \\
$8 \mathrm{H}-7,0-5$ & 74.50 & 2.79 \\
$9 \mathrm{H}-7,0-5$ & 83.15 & 2.79 \\
$11 \mathrm{H}-7,0-5$ & 102.61 & 3.27 \\
$12 \mathrm{H}-7,0-5$ & 112.50 & 3.10 \\
$13 \mathrm{H}-7,0-5$ & 120.97 & 3.37 \\
$14 \mathrm{H}-7,0-5$ & 131.22 & 4.34 \\
$15 \mathrm{H}-7,0-5$ & 140.49 & 3.87 \\
$16 \mathrm{H}-7,0-5$ & 150.36 & 4.13 \\
$17 \mathrm{X}-7,0-5$ & 159.91 & 3.30 \\
$18 \mathrm{X}-7,0-5$ & 169.42 & 3.86 \\
$19 \mathrm{X}-7,0-5$ & 179.01 & 3.82 \\
$20 \mathrm{X}-7,0-5$ & 188.61 & 4.69 \\
$21 \mathrm{X}-7,0-5$ & 197.37 & 4.42 \\
$22 \mathrm{X}-7,0-5$ & 208.00 & 3.65 \\
$23 \mathrm{X}-7,0-5$ & 217.50 & 6.00 \\
$24 \mathrm{X}-6,0-5$ & 225.50 & 5.14 \\
$25 \mathrm{X}-4,0-5$ & 232.00 & 4.22 \\
$26 \mathrm{X}-2,0-5$ & 238.60 & 6.72 \\
$27 \mathrm{X}-6,0-5$ & 254.20 & 4.15 \\
$28 \mathrm{X}-2,0-5$ & 257.80 & 4.19 \\
\hline
\end{tabular}


Table T19. Interstitial water constituents, Hole U1410A.

\begin{tabular}{|c|c|c|c|c|c|c|c|c|c|c|c|c|c|c|c|}
\hline $\begin{array}{l}\text { Core, section, } \\
\text { interval }(\mathrm{cm})\end{array}$ & $\begin{array}{l}\text { Depth } \\
\text { (mbsf) }\end{array}$ & $\mathrm{pH}$ & $\begin{array}{l}\text { Alkalinity } \\
(\mathrm{mM})\end{array}$ & $\begin{array}{l}\text { Ammonium } \\
(\mu \mathrm{M})\end{array}$ & Salinity & $\begin{array}{c}\mathrm{Cl}^{-} \\
(\mathrm{mM})\end{array}$ & $\begin{array}{l}\mathrm{Na}^{+} \\
(\mathrm{mM})\end{array}$ & $\begin{array}{l}\mathrm{SO}_{4}{ }^{2-} \\
(\mathrm{mM})\end{array}$ & $\begin{array}{c}\mathrm{HPO}_{4}^{-} \\
(\mu \mathrm{M})\end{array}$ & $\begin{array}{l}\mathrm{Mn}^{2+} \\
(\mu \mathrm{M})\end{array}$ & $\begin{array}{c}\mathrm{Fe}^{2+} \\
(\mu \mathrm{M})\end{array}$ & $\begin{array}{l}\mathrm{Ca}^{2+} \\
(\mathrm{mM})\end{array}$ & $\begin{array}{l}\mathrm{Mg}^{2+} \\
(\mathrm{mM})\end{array}$ & $\begin{array}{c}\mathrm{K}^{+} \\
(\mathrm{mM})\end{array}$ & $\begin{array}{c}B \\
(\mu \mathrm{M})\end{array}$ \\
\hline \multicolumn{16}{|l|}{ 342-U1310A- } \\
\hline $1 \mathrm{H}-5,145-150$ & 7.45 & 7.45 & 3.544 & 42 & 38 & 551.989 & 470.685 & 28.871 & BDL & 7.702 & ND & 11.36 & 53.862 & 14.929 & 375.538 \\
\hline $2 \mathrm{H}-6,145-150$ & 17.45 & 7.51 & 3.545 & 105 & 37 & 555.186 & 477.705 & 27.764 & BDL & 6.631 & 5.272 & 11.382 & 53.639 & 15.132 & 374.944 \\
\hline $3 \mathrm{H}-6,145-150$ & 26.95 & 7.47 & 3.433 & 50 & 37 & 561.292 & 481.021 & 27.159 & BDL & 7.432 & 10.861 & 11.6 & 53.098 & 16.318 & 523.419 \\
\hline $4 \mathrm{H}-6,145-150$ & 36.45 & 7.57 & 3.843 & 44 & 37 & 553.43 & 474.916 & 27.324 & BDL & 7.115 & 5.747 & 11.944 & 53.275 & 14.894 & 579.423 \\
\hline $5 \mathrm{H}-6,106-111$ & 45.56 & 7.41 & 3.222 & 63 & 37 & 545.828 & 476.271 & 26.526 & BDL & 6.281 & 5.617 & 12.203 & 52.299 & 14.752 & 489.01 \\
\hline $6 \mathrm{H}-6,136-141$ & 55.36 & 7.44 & 3.75 & 58 & 37 & 556.715 & 480.495 & 27.366 & BDL & 6.393 & 5.233 & 13.165 & 54.065 & 12.484 & 516.206 \\
\hline $7 \mathrm{H}-6,147-152$ & 63.50 & 7.32 & 3.803 & 52 & 37 & 580.964 & 473.982 & 26.861 & BDL & 5.805 & 1.467 & 13.414 & 53.282 & 11.736 & 559.207 \\
\hline $8 \mathrm{H}-6,140-150$ & 74.40 & 7.25 & 3.591 & 78 & 37 & 560.976 & 486.185 & 25.829 & BDL & 5.519 & 46.856 & 13.806 & 51.873 & 12.638 & 507.657 \\
\hline $9 \mathrm{H}-6,140-150$ & 83.05 & 7.17 & 3.62 & 44 & 36 & 553.411 & 477.408 & 26.278 & BDL & 5.319 & 49.008 & 14.124 & 50.691 & 11.538 & 512.154 \\
\hline $11 \mathrm{H}-6,101-111$ & 102.51 & 7.14 & 3.905 & 74 & 37 & 546.272 & 474.283 & 24.397 & BDL & 6.476 & 71.14 & 14.885 & 49.071 & 11.63 & 502.417 \\
\hline $12 \mathrm{H}-6,140-150$ & 112.40 & 7.15 & 3.917 & 49 & 37 & 551.084 & 480.479 & 25.53 & BDL & 6.832 & 58.565 & 15.756 & 49.297 & 10.636 & 504.39 \\
\hline $13 \mathrm{H}-6,140-150$ & 120.87 & 7.14 & 4.196 & 100 & 37 & 561.386 & 488.687 & 25.285 & BDL & 7.329 & 77.807 & 16.587 & 49.847 & 9.529 & 457.296 \\
\hline $14 \mathrm{H}-6,112-122$ & 131.12 & 7.06 & 4.001 & 120 & 37 & 549.331 & 478.322 & 25.093 & BDL & 7.63 & 44.514 & 16.707 & 48.723 & 8.576 & 446.519 \\
\hline 15H-6, 91-101 & 140.39 & 7.001 & 4.396 & 47 & 37 & 555.47 & 485.628 & 24.704 & BDL & 9.26 & 35.271 & 17.538 & 48.904 & 8.118 & 472.294 \\
\hline $16 \mathrm{H}-6,126-136$ & 150.26 & 7.007 & 4.744 & 56 & 37 & 537.585 & 465.726 & 24.21 & $\mathrm{BDL}$ & 9.831 & 22.243 & 17.67 & 47.376 & 7.012 & 529.422 \\
\hline $17 X-6,133-141$ & 159.83 & 6.961 & 4.76 & 52 & 37 & 549.872 & 474.491 & 24.072 & BDL & 11.67 & 31.492 & 18.356 & 47.989 & 11.184 & 482.604 \\
\hline $18 X-6,122-132$ & 169.32 & 6.932 & 4.994 & 82 & 37 & 557.461 & 481.917 & 24.657 & BDL & 11.763 & 24.256 & 19.122 & 47.824 & 11.555 & 494.823 \\
\hline $19 X-6,121-131$ & 178.91 & 6.959 & 5.151 & 74 & 37 & 557.425 & 487.646 & 23.918 & BDL & 12.456 & 33.862 & 19.689 & 46.963 & 11.549 & 476.939 \\
\hline $20 X-6,121-131$ & 188.51 & 7.018 & 5.061 & 107 & 37 & 550.797 & 478.777 & 23.972 & BDL & 14.872 & 23.869 & 19.875 & 46.202 & 11.162 & 507.848 \\
\hline $22 \mathrm{X}-6,140-150$ & 207.90 & 7.026 & 4.305 & 95 & 37 & 576.232 & 468.218 & 22.562 & BDL & 8.862 & 2.427 & 20.402 & 44.327 & 10.97 & 456.129 \\
\hline $23 X-6,140-150$ & 217.40 & 6.872 & 4.82 & 109 & 37 & 551.099 & 479.456 & 23.618 & BDL & 6.061 & 0.323 & 20.349 & 43.912 & 11.699 & 407.422 \\
\hline $25 X-3,140-150$ & 231.90 & 6.821 & 5.194 & 79 & 38 & 555.392 & 482.376 & 23.132 & BDL & 3.943 & 0.316 & 21.188 & 43.831 & 10.94 & 396.9 \\
\hline $26 \mathrm{X}-1,140-150$ & 238.50 & 7.016 & 5.289 & 119 & 38 & 563.387 & 493.388 & 24.016 & BDL & 3.799 & 0.257 & 22.122 & 44.064 & 11.083 & 383.896 \\
\hline $27 X-5,140-150$ & 254.10 & 6.851 & 5.656 & 155 & 37 & 556.977 & 480.682 & 21.716 & BDL & 10.882 & 0.21 & 23.532 & 39.205 & 10.345 & 478.828 \\
\hline
\end{tabular}

$\mathrm{BDL}=$ below detection limit $\left(\mathrm{HPO}_{4}^{-}=0.2 \mu \mathrm{M}\right)$, calculated as two times the standard deviation of multiple measures of a blank. ND = not detected. 
Table T20. Sedimentary sample and bulk elemental geochemistry, Hole U1410A. (Continued on next two pages.)

\begin{tabular}{|c|c|c|c|c|c|c|}
\hline $\begin{array}{l}\text { Core, section, } \\
\text { interval }(\mathrm{cm})\end{array}$ & $\begin{array}{l}\text { Depth } \\
\text { (mbsf) }\end{array}$ & $\begin{array}{c}\mathrm{CaCO}_{3} \\
(\mathrm{wt} \%)\end{array}$ & $\begin{array}{c}\text { IC } \\
(w t \%)\end{array}$ & $\begin{array}{c}\mathrm{TC} \\
\text { (wt\%) }\end{array}$ & $\begin{array}{c}\mathrm{TN} \\
\text { (wt\%) }\end{array}$ & $\begin{array}{c}\text { TOC } \\
\text { (wt\%) }\end{array}$ \\
\hline \multicolumn{7}{|l|}{ 342-U1410A- } \\
\hline $1 \mathrm{H}-1,148-149$ & 1.48 & 48.02 & 5.76 & 5.92 & 0.06 & 0.16 \\
\hline $1 \mathrm{H}-2,38-39$ & 1.88 & 50.36 & 6.04 & 6.47 & 0.08 & 0.43 \\
\hline $1 \mathrm{H}-3,61-62$ & 3.61 & 19.698 & 2.362 & 1.69 & 0.08 & $\mathrm{BDL}$ \\
\hline $1 \mathrm{H}-4,46-47$ & 4.96 & 24.393 & 2.925 & 3.13 & 0.06 & 0.21 \\
\hline $1 \mathrm{H}-5,31-32$ & 6.31 & 34.712 & 4.162 & 4.55 & 0.11 & 0.39 \\
\hline $1 \mathrm{H}-6,20-21$ & 7.70 & 66.405 & 7.962 & 7.66 & 0.03 & $\mathrm{BDL}$ \\
\hline $2 \mathrm{H}-1,39-40$ & 8.89 & 39.71 & 4.761 & 4.98 & 0.03 & 0.22 \\
\hline $2 \mathrm{H}-2,38-39$ & 10.38 & 50.147 & 6.012 & 6.08 & 0.04 & 0.07 \\
\hline $2 \mathrm{H}-3,38-39$ & 11.88 & 46.452 & 5.569 & 5.95 & 0.08 & 0.38 \\
\hline $2 \mathrm{H}-4,38-39$ & 13.38 & 60.91 & 7.303 & 7.47 & 0.05 & 0.17 \\
\hline $2 \mathrm{H}-5,38-39$ & 14.88 & 8.025 & 0.962 & 1.35 & 0.11 & 0.39 \\
\hline $2 \mathrm{H}-6,38-39$ & 16.38 & 35.062 & 4.204 & 4.73 & 0.11 & 0.53 \\
\hline $2 \mathrm{H}-7,18-19$ & 17.68 & 44.481 & 5.333 & 5.90 & 0.06 & 0.57 \\
\hline $3 \mathrm{H}-1,38-39$ & 18.38 & 61.207 & 7.339 & 7.68 & 0.05 & 0.34 \\
\hline $3 \mathrm{H}-2,38-39$ & 19.88 & 40.174 & 4.817 & 4.92 & 0.04 & 0.10 \\
\hline $3 \mathrm{H}-3,38-39$ & 21.38 & 38.652 & 4.634 & 4.85 & 0.08 & 0.22 \\
\hline $3 \mathrm{H}-4,38-39$ & 22.88 & 50.68 & 6.076 & 6.29 & 0.05 & 0.21 \\
\hline $3 \mathrm{H}-5,38-39$ & 24.38 & 40.793 & 4.891 & 5.18 & 0.05 & 0.29 \\
\hline $3 \mathrm{H}-6,38-39$ & 25.88 & 26.169 & 3.138 & 3.27 & 0.07 & 0.13 \\
\hline $3 \mathrm{H}-7,18-19$ & 27.18 & 31.629 & 3.792 & 3.64 & 0.06 & $\mathrm{BDL}$ \\
\hline $4 \mathrm{H}-1,38-39$ & 27.88 & 22.018 & 2.64 & 3.04 & 0.09 & 0.40 \\
\hline $4 \mathrm{H}-2,38-39$ & 29.38 & 23.796 & 2.853 & 3.23 & 0.08 & 0.38 \\
\hline $4 \mathrm{H}-3,38-39$ & 30.88 & 13.237 & 1.587 & 1.88 & 0.10 & 0.29 \\
\hline $4 \mathrm{H}-4,35-36$ & 32.35 & 11.073 & 1.328 & 1.77 & 0.36 & 0.44 \\
\hline $4 \mathrm{H}-5,38-39$ & 33.88 & 6.951 & 0.833 & 1.22 & 0.11 & 0.39 \\
\hline $4 \mathrm{H}-6,38-39$ & 35.38 & 3.345 & 0.401 & 0.72 & 0.12 & 0.32 \\
\hline $4 \mathrm{H}-7,18-19$ & 36.68 & 12.808 & 1.536 & 1.97 & 0.13 & 0.43 \\
\hline $5 \mathrm{H}-1,60-61$ & 37.60 & 6.87 & 0.824 & 1.34 & 0.14 & 0.52 \\
\hline $5 \mathrm{H}-2,38-39$ & 38.88 & 12.216 & 1.465 & 1.64 & 0.13 & 0.18 \\
\hline $5 \mathrm{H}-3,38-39$ & 40.38 & 17.832 & 2.138 & 2.70 & 0.14 & 0.56 \\
\hline $5 \mathrm{H}-4,38-39$ & 41.88 & 3.997 & 0.479 & 0.64 & 0.07 & 0.16 \\
\hline $5 \mathrm{H}-5,38-39$ & 43.38 & 0.691 & 0.083 & 0.20 & 0.07 & 0.12 \\
\hline $5 \mathrm{H}-6,25-26$ & 44.75 & 17.662 & 2.118 & 2.20 & 0.05 & 0.08 \\
\hline $5 \mathrm{H}-7,13-14$ & 45.74 & 17.927 & 2.149 & 2.25 & 0.06 & 0.10 \\
\hline $6 \mathrm{H}-1,38-39$ & 46.88 & 16.287 & 1.953 & 2.05 & 0.06 & 0.10 \\
\hline $6 \mathrm{H}-2,38-39$ & 48.38 & 6.762 & 0.811 & 0.92 & 0.05 & 0.11 \\
\hline $6 \mathrm{H}-3,38-39$ & 49.88 & 11.857 & 1.422 & & & \\
\hline $6 \mathrm{H}-4,38-39$ & 51.38 & 2.738 & 0.328 & 0.43 & 0.06 & 0.10 \\
\hline $6 \mathrm{H}-5,38-39$ & 52.88 & 6.908 & 0.828 & 2.04 & 0.06 & 1.21 \\
\hline $6 \mathrm{H}-6,38-39$ & 54.38 & 5.904 & 0.708 & 0.77 & 0.05 & 0.06 \\
\hline $6 \mathrm{H}-7,16-17$ & 55.57 & 8.089 & 0.97 & 1.14 & 0.08 & 0.17 \\
\hline 7H-1, 38-39 & 56.38 & 12.79 & 1.533 & 1.58 & 0.06 & 0.05 \\
\hline $7 \mathrm{H}-2,38-39$ & 57.90 & 8.191 & 0.982 & 1.15 & 0.07 & 0.17 \\
\hline $7 \mathrm{H}-3,15-16$ & 59.20 & 22.467 & 2.694 & 2.84 & 0.07 & 0.15 \\
\hline $7 \mathrm{H}-4,30-31$ & 59.97 & 13.404 & 1.607 & 1.74 & 0.07 & 0.13 \\
\hline $7 \mathrm{H}-5,30-31$ & 61.19 & 17.342 & 2.079 & 2.16 & 0.07 & 0.08 \\
\hline $7 \mathrm{H}-6,30-31$ & 62.33 & 17.787 & 2.133 & 2.27 & 0.07 & 0.14 \\
\hline 7H-7, 38-39 & 63.93 & 3.413 & 0.409 & 0.66 & 0.06 & 0.25 \\
\hline $8 \mathrm{H}-1,38-39$ & 65.88 & 37.161 & 4.456 & 4.45 & 0.07 & $\mathrm{BDL}$ \\
\hline $8 \mathrm{H}-2,38-39$ & 67.38 & 36.307 & 4.353 & 4.62 & 0.08 & 0.27 \\
\hline $8 \mathrm{H}-3,38-39$ & 68.88 & 51.347 & 6.156 & 6.44 & 0.04 & 0.28 \\
\hline $8 \mathrm{H}-4,38-39$ & 70.38 & 29.52 & 3.539 & 3.74 & 0.07 & 0.20 \\
\hline $8 \mathrm{H}-5,38-39$ & 71.88 & 54.953 & 6.589 & 6.67 & 0.05 & 0.08 \\
\hline $8 \mathrm{H}-6,38-39$ & 73.38 & 38.405 & 4.605 & 4.67 & 0.05 & 0.07 \\
\hline $8 \mathrm{H}-7,9-10$ & 74.59 & 58.643 & 7.031 & 7.28 & 0.06 & 0.25 \\
\hline $9 \mathrm{H}-1,24-25$ & 75.24 & 37.961 & 4.551 & & & \\
\hline $9 \mathrm{H}-2,38-39$ & 76.88 & 34.174 & 4.097 & 4.36 & 0.07 & 0.26 \\
\hline $9 \mathrm{H}-3,12-13$ & 78.12 & 47.947 & 5.749 & & & \\
\hline $9 \mathrm{H}-4,38-39$ & 79.03 & 30.851 & 3.699 & 3.88 & 0.07 & 0.18 \\
\hline $9 \mathrm{H}-5,38-39$ & 80.53 & 75.623 & 9.067 & & & \\
\hline $9 \mathrm{H}-6,38-39$ & 82.03 & 20.215 & 2.424 & 2.55 & 0.07 & 0.13 \\
\hline $9 \mathrm{H}-7,20-21$ & 83.35 & 25.455 & 3.052 & 3.28 & 0.07 & 0.23 \\
\hline $10 \mathrm{H}-1,9-10$ & 84.59 & 33.022 & 3.959 & 4.11 & 0.06 & 0.15 \\
\hline $10 \mathrm{H}-2,20-21$ & 85.20 & 32.85 & 3.939 & 4.18 & 0.07 & 0.24 \\
\hline $10 \mathrm{H}-3,30-31$ & 85.98 & 48.819 & 5.853 & 5.93 & 0.05 & 0.08 \\
\hline $10 \mathrm{H}-4,38-39$ & 87.53 & 36.994 & 4.436 & 4.60 & 0.06 & 0.16 \\
\hline
\end{tabular}


Table T20 (continued). (Continued on next page.)

\begin{tabular}{|c|c|c|c|c|c|c|}
\hline $\begin{array}{l}\text { Core, section, } \\
\text { interval }(\mathrm{cm})\end{array}$ & $\begin{array}{l}\text { Depth } \\
\text { (mbsf) }\end{array}$ & $\begin{array}{l}\mathrm{CaCO}_{3} \\
\text { (wt\%) }\end{array}$ & $\begin{array}{c}\text { IC } \\
(w t \%)\end{array}$ & $\begin{array}{c}\text { TC } \\
(w t \%)\end{array}$ & $\begin{array}{c}\mathrm{TN} \\
(\mathrm{wt} \%)\end{array}$ & $\begin{array}{l}\text { TOC } \\
\text { (wt\%) }\end{array}$ \\
\hline $10 \mathrm{H}-5,38-39$ & 88.63 & 26.261 & 3.149 & 3.36 & 0.08 & 0.21 \\
\hline $10 \mathrm{H}-6,38-39$ & 90.03 & 32.988 & 3.955 & 4.11 & 0.07 & 0.15 \\
\hline $10 \mathrm{H}-7,38-39$ & 91.44 & 53.821 & 6.453 & & & \\
\hline $11 \mathrm{H}-1,38-39$ & 94.38 & 53.513 & 6.416 & 6.58 & 0.05 & 0.16 \\
\hline $11 \mathrm{H}-2,38-39$ & 95.88 & 47.617 & 5.709 & 5.89 & 0.05 & 0.18 \\
\hline $11 \mathrm{H}-3,38-39$ & 97.38 & 31.328 & 3.756 & 4.05 & 0.08 & 0.29 \\
\hline $11 \mathrm{H}-4,38-39$ & 98.88 & 80.765 & 9.683 & 10.06 & 0.01 & 0.38 \\
\hline $11 \mathrm{H}-5,38-39$ & 100.38 & 48.142 & 5.772 & 5.92 & 0.06 & 0.15 \\
\hline $11 \mathrm{H}-6,23-24$ & 101.73 & 42.946 & 5.149 & 5.41 & 0.07 & 0.26 \\
\hline $11 \mathrm{H}-7,10-11$ & 102.71 & 35.597 & 4.268 & 4.42 & 0.08 & 0.15 \\
\hline $12 \mathrm{H}-1,38-39$ & 103.88 & 56.709 & 6.799 & 6.45 & 0.05 & $\mathrm{BDL}$ \\
\hline $12 \mathrm{H}-2,38-39$ & 105.38 & 41.627 & 4.991 & 4.96 & 0.07 & $\mathrm{BDL}$ \\
\hline $12 \mathrm{H}-3,38-39$ & 106.88 & 84.975 & 10.188 & 9.81 & 0.03 & $\mathrm{BDL}$ \\
\hline $12 \mathrm{H}-4,38-39$ & 108.38 & 47.336 & 5.675 & 5.67 & 0.07 & BDL \\
\hline $12 \mathrm{H}-5,38-39$ & 109.88 & 33.83 & 4.056 & 4.1 & 0.08 & 0.04 \\
\hline $12 \mathrm{H}-6,38-39$ & 111.38 & 67.466 & 8.089 & 7.55 & 0.03 & $\mathrm{BDL}$ \\
\hline $12 \mathrm{H}-7,17-18$ & 112.67 & 43.963 & 5.271 & 5.15 & 0.06 & $\mathrm{BDL}$ \\
\hline $13 \mathrm{H}-1,24-25$ & 113.24 & 40.134 & 4.812 & 4.93 & 0.07 & 0.12 \\
\hline $13 \mathrm{H}-2,38-39$ & 113.85 & 47.502 & 5.695 & 5.6 & 0.07 & $\mathrm{BDL}$ \\
\hline $13 \mathrm{H}-3,38-39$ & 115.35 & 32.639 & 3.913 & 3.92 & 0.08 & 0.01 \\
\hline $13 \mathrm{H}-4,38-39$ & 116.85 & 30.207 & 3.622 & 3.64 & 0.08 & 0.02 \\
\hline $13 \mathrm{H}-5,38-39$ & 118.35 & 34.751 & 4.167 & 4.05 & 0.08 & $\mathrm{BDL}$ \\
\hline $13 \mathrm{H}-6,38-39$ & 119.85 & 40.509 & 4.857 & 4.73 & 0.07 & $\mathrm{BDL}$ \\
\hline $13 \mathrm{H}-7,38-39$ & 121.35 & 37.475 & 4.493 & 4.64 & 0.08 & 0.15 \\
\hline $14 \mathrm{H}-1,38-39$ & 122.88 & 29.022 & 3.48 & 3.53 & 0.08 & 0.05 \\
\hline $14 \mathrm{H}-2,38-39$ & 124.38 & 28.188 & 3.38 & 3.33 & 0.08 & $\mathrm{BDL}$ \\
\hline $14 \mathrm{H}-3,38-39$ & 125.88 & 33.588 & 4.027 & 3.85 & 0.06 & $\mathrm{BDL}$ \\
\hline $14 \mathrm{H}-4,38-39$ & 127.38 & 31.84 & 3.817 & 3.69 & 0.08 & $\mathrm{BDL}$ \\
\hline $14 \mathrm{H}-5,38-39$ & 128.88 & 39.807 & 4.773 & 4.66 & 0.08 & $\mathrm{BDL}$ \\
\hline $14 \mathrm{H}-6,38-39$ & 130.38 & 37.299 & 4.472 & 4.67 & 0.1 & 0.20 \\
\hline $14 \mathrm{H}-7,18-19$ & 131.40 & 41.696 & 4.999 & 4.87 & 0.06 & $\mathrm{BDL}$ \\
\hline $15 \mathrm{H}-1,140-141$ & 133.40 & 81.663 & 9.791 & 9.38 & 0.02 & $\mathrm{BDL}$ \\
\hline $15 \mathrm{H}-2,38-39$ & 133.86 & 52.685 & 6.317 & 6.07 & 0.07 & $\mathrm{BDL}$ \\
\hline $15 \mathrm{H}-3,38-39$ & 135.36 & 46.086 & 5.526 & 5.23 & 0.06 & BDL \\
\hline $15 \mathrm{H}-4,38-39$ & 136.86 & 37.927 & 4.547 & 4.51 & 0.09 & BDL \\
\hline $15 \mathrm{H}-5,39-40$ & 138.37 & 43.744 & 5.245 & 5.68 & 0.08 & 0.44 \\
\hline $15 \mathrm{H}-6,20-21$ & 139.68 & 47.826 & 5.734 & 5.46 & 0.06 & $\mathrm{BDL}$ \\
\hline $15 \mathrm{H}-7,15-16$ & 140.64 & 37.716 & 4.522 & 4.35 & 0.08 & $\mathrm{BDL}$ \\
\hline $16 \mathrm{H}-1,39-40$ & 141.89 & 44.488 & 5.334 & 5.41 & 0.08 & 0.08 \\
\hline $16 \mathrm{H}-2,39-40$ & 143.39 & 43.41 & 5.205 & 5.31 & 0.07 & 0.11 \\
\hline $16 \mathrm{H}-3,39-40$ & 144.89 & 33.15 & 3.975 & 4.25 & 0.11 & 0.28 \\
\hline $16 \mathrm{H}-4,39-40$ & 146.39 & 34.637 & 4.153 & 4.26 & 0.09 & 0.11 \\
\hline $16 \mathrm{H}-5,31-32$ & 147.81 & 38.08 & 4.566 & 4.85 & 0.1 & 0.28 \\
\hline $16 \mathrm{H}-6,31-32$ & 149.31 & 33.855 & 4.059 & 4.09 & 0.07 & 0.03 \\
\hline $16 \mathrm{H}-7,15-16$ & 150.51 & 29.201 & 3.501 & 3.78 & 0.09 & 0.28 \\
\hline $17 X-1,38-39$ & 151.38 & 45.086 & 5.406 & 5.33 & 0.08 & $\mathrm{BDL}$ \\
\hline $17 X-2,38-39$ & 152.88 & 72.754 & 8.723 & 8.26 & 0.05 & $\mathrm{BDL}$ \\
\hline $17 X-3,38-39$ & 154.38 & 41.769 & 5.008 & 4.88 & 0.07 & BDL \\
\hline $17 X-4,37-38$ & 155.87 & 34.983 & 4.194 & 4.04 & 0.07 & $\mathrm{BDL}$ \\
\hline $17 X-5,37-38$ & 157.37 & 43.254 & 5.186 & 5.1 & 0.06 & $\mathrm{BDL}$ \\
\hline $17 X-5,73-74$ & 157.73 & 77.824 & 9.331 & 9.08 & 0.02 & $\mathrm{BDL}$ \\
\hline $17 X-6,26-27$ & 158.76 & 53.577 & 6.424 & 6.05 & 0.04 & $\mathrm{BDL}$ \\
\hline $17 X-7,13-14$ & 160.04 & 48.614 & 5.829 & 5.49 & 0.05 & $\mathrm{BDL}$ \\
\hline $18 X-1,38-39$ & 160.98 & 44.042 & 5.281 & 4.84 & 0.05 & $\mathrm{BDL}$ \\
\hline $18 X-2,40-41$ & 162.50 & 41.805 & 5.012 & 4.75 & 0.06 & $\mathrm{BDL}$ \\
\hline $18 X-3,39-40$ & 163.99 & 40.169 & 4.816 & 4.41 & 0.04 & BDL \\
\hline $18 X-4,39-40$ & 165.49 & 40.667 & 4.876 & 4.53 & 0.04 & $\mathrm{BDL}$ \\
\hline $18 X-5,39-40$ & 166.99 & 48.82 & 5.853 & 5.46 & 0.06 & $\mathrm{BDL}$ \\
\hline $18 \mathrm{X}-6,29-30$ & 168.39 & 54.97 & 6.591 & 6.27 & 0.05 & $\mathrm{BDL}$ \\
\hline $18 X-7,14-15$ & 169.56 & 41.593 & 4.987 & 4.7 & 0.06 & $\mathrm{BDL}$ \\
\hline $19 X-1,41-42$ & 170.61 & 49.852 & 5.977 & 5.96 & 0.07 & $\mathrm{BDL}$ \\
\hline $19 X-2,40-41$ & 172.10 & 47.25 & 5.665 & 5.47 & 0.06 & BDL \\
\hline $19 X-3,40-41$ & 173.60 & 32.916 & 3.947 & 3.77 & 0.08 & $\mathrm{BDL}$ \\
\hline $19 X-4,39-40$ & 175.09 & 37.204 & 4.461 & 4.19 & 0.06 & $\mathrm{BDL}$ \\
\hline $19 X-5,39-40$ & 176.59 & 44.626 & 5.351 & 4.97 & 0.06 & $\mathrm{BDL}$ \\
\hline $19 X-6,39-40$ & 178.09 & 44.191 & 5.298 & 5.04 & 0.03 & $\mathrm{BDL}$ \\
\hline $19 X-7,14-15$ & 179.15 & 45.561 & 5.463 & 5.19 & 0.07 & $\mathrm{BDL}$ \\
\hline $20 X-1,38-39$ & 180.18 & 52.441 & 6.287 & 5.92 & 0.04 & BDL \\
\hline $20 X-2,40-41$ & 181.70 & 45.226 & 5.422 & 5.02 & 0.05 & $\mathrm{BDL}$ \\
\hline
\end{tabular}


Table T20 (continued).

\begin{tabular}{|c|c|c|c|c|c|c|}
\hline $\begin{array}{l}\text { Core, section, } \\
\text { interval }(\mathrm{cm})\end{array}$ & $\begin{array}{l}\text { Depth } \\
\text { (mbsf) }\end{array}$ & $\begin{array}{l}\mathrm{CaCO}_{3} \\
(\mathrm{wt} \%)\end{array}$ & $\begin{array}{c}\text { IC } \\
\text { (wt\%) }\end{array}$ & $\begin{array}{c}\mathrm{TC} \\
(\mathrm{wt} \%)\end{array}$ & $\begin{array}{c}\mathrm{TN} \\
\text { (wt\%) }\end{array}$ & $\begin{array}{c}\text { TOC } \\
\text { (wt\%) }\end{array}$ \\
\hline $20 \times-3,38-39$ & 183.18 & 47.581 & 5.705 & 5.41 & 0.05 & $\mathrm{BDL}$ \\
\hline $20 \times-4,38-39$ & 184.68 & 38.812 & 4.653 & 4.4 & 0.06 & BDL \\
\hline $20 x-5,38-39$ & 186.18 & 41.199 & 4.94 & 4.76 & 0.07 & BDL \\
\hline $20 \times-6,33-34$ & 187.63 & 48.802 & 5.851 & 5.48 & 0.07 & $\mathrm{BDL}$ \\
\hline $20 x-7,15-16$ & 188.76 & 43.024 & 5.158 & 4.87 & 0.06 & $\mathrm{BDL}$ \\
\hline $21 X-1,21-22$ & 189.61 & 47.431 & 5.687 & 5.35 & 0.05 & BDL \\
\hline $21 X-2,38-39$ & 190.42 & 38.23 & 4.584 & 4.31 & 0.06 & BDL \\
\hline $21 X-3,38-39$ & 191.92 & 39.067 & 4.684 & 4.31 & 0.04 & $\mathrm{BDL}$ \\
\hline $21 X-4,17-18$ & 193.17 & 48.909 & 5.864 & 5.58 & 0.06 & $\mathrm{BDL}$ \\
\hline $21 X-5,42-43$ & 194.79 & 46.897 & 5.623 & 5.32 & 0.06 & BDL \\
\hline $21 X-6,45-46$ & 196.32 & 50.099 & 6.007 & 5.66 & 0.04 & $\mathrm{BDL}$ \\
\hline $21 X-7,42-43$ & 197.79 & 45.547 & 5.461 & 5.17 & 0.05 & $\mathrm{BDL}$ \\
\hline $22 \mathrm{X}-1,35-36$ & 199.35 & 48.482 & 5.813 & 5.59 & 0.05 & $\mathrm{BDL}$ \\
\hline $22 X-2,38-39$ & 200.88 & 46.922 & 5.626 & 5.3 & 0.06 & $\mathrm{BDL}$ \\
\hline $22 X-3,38-39$ & 202.38 & 42.06 & 5.043 & 4.69 & 0.05 & BDL \\
\hline $22 X-4,35-36$ & 203.85 & 51.933 & 6.227 & 6.24 & 0.19 & 0.01 \\
\hline $22 X-5,38-39$ & 205.38 & 43.788 & 5.25 & 4.99 & 0.05 & $\mathrm{BDL}$ \\
\hline $22 \mathrm{X}-6,38-39$ & 206.88 & 36.884 & 4.422 & 4.37 & 0.07 & $\mathrm{BDL}$ \\
\hline $22 X-7,12-13$ & 208.12 & 45.61 & 5.469 & 5.46 & 0.07 & $\mathrm{BDL}$ \\
\hline $23 X-1,38-39$ & 208.88 & 52.206 & 6.259 & 5.91 & 0.04 & $\mathrm{BDL}$ \\
\hline $23 \times-2,48-49$ & 210.48 & 85.287 & 10.226 & 9.69 & 0.01 & $\mathrm{BDL}$ \\
\hline $23 X-3,35-36$ & 211.85 & 92.568 & 11.099 & 10.52 & 0.02 & BDL \\
\hline $23 X-4,43-44$ & 213.43 & 84.924 & 10.182 & 9.53 & 0.03 & $\mathrm{BDL}$ \\
\hline $23 X-5,38-39$ & 214.88 & 85.159 & 10.21 & 9.54 & 0.01 & BDL \\
\hline $23 X-6,40-41$ & 216.40 & 86.546 & 10.377 & 9.72 & 0.22 & $\mathrm{BDL}$ \\
\hline $23 X-7,10-11$ & 217.60 & 81.882 & 9.817 & 8.99 & 0 & BDL \\
\hline $24 \mathrm{X}-1,43-44$ & 218.43 & 87.204 & 10.455 & 10.35 & 0 & BDL \\
\hline $24 \mathrm{X}-2,44-45$ & 219.94 & 87.971 & 10.548 & 10.42 & 0 & $\mathrm{BDL}$ \\
\hline $24 X-3,44-45$ & 221.44 & 84.03 & 10.075 & 9.88 & 0.08 & $\mathrm{BDL}$ \\
\hline $24 X-4,53-54$ & 223.03 & 82.72 & 9.918 & 10.03 & 0.01 & 0.11 \\
\hline $24 \mathrm{X}-5,38-39$ & 224.38 & 85.025 & 10.194 & 10.02 & 0.08 & $\mathrm{BDL}$ \\
\hline $24 \mathrm{X}-6,44-45$ & 225.94 & 87.655 & 10.51 & 10.11 & 0.01 & $\mathrm{BDL}$ \\
\hline $25 \mathrm{X}-1,29-30$ & 227.79 & 87.831 & 10.531 & 10.22 & 0 & $\mathrm{BDL}$ \\
\hline $25 X-2,26-27$ & 229.26 & 88.827 & 10.65 & 10.28 & 0 & $\mathrm{BDL}$ \\
\hline $25 X-3,33-34$ & 230.83 & 86.958 & 10.426 & 10.07 & 0.01 & $\mathrm{BDL}$ \\
\hline $25 X-4,34-35$ & 232.34 & 86.343 & 10.352 & 10.07 & 0 & BDL \\
\hline $26 \mathrm{X}-1,23-24$ & 237.33 & 84.674 & 10.152 & 9.65 & 0.01 & $\mathrm{BDL}$ \\
\hline $26 \mathrm{X}-2,41-42$ & 239.01 & 85.587 & 10.262 & 10.04 & 0.09 & $\mathrm{BDL}$ \\
\hline $26 \mathrm{X}-3,25-26$ & 240.35 & 85.406 & 10.24 & 9.89 & 0.11 & $\mathrm{BDL}$ \\
\hline $26 \mathrm{X}-4,25-26$ & 241.85 & 89.545 & 10.736 & 10.62 & 0.1 & $\mathrm{BDL}$ \\
\hline $26 \times-5,18-19$ & 243.28 & 84.594 & 10.143 & 9.33 & 0.01 & $\mathrm{BDL}$ \\
\hline $26 \mathrm{X}-6,42-43$ & 245.02 & 91.766 & 11.002 & 10.43 & 0.1 & $\mathrm{BDL}$ \\
\hline $27 \mathrm{X}-1,44-45$ & 247.14 & 89.77 & 10.763 & 10.56 & 0.01 & BDL \\
\hline $27 X-2,54-55$ & 248.74 & 90.33 & 10.83 & 10.41 & 0.01 & $\mathrm{BDL}$ \\
\hline $27 X-3,47-48$ & 250.17 & 92.354 & 11.073 & 10.11 & 0 & $\mathrm{BDL}$ \\
\hline $27 X-4,93-94$ & 252.13 & 89.137 & 10.687 & 10.31 & 0.02 & $\mathrm{BDL}$ \\
\hline $27 X-5,75-76$ & 253.45 & 90.924 & 10.901 & 10.51 & 0 & $\mathrm{BDL}$ \\
\hline $27 X-6,34-35$ & 254.54 & 90.326 & 10.83 & 10.51 & 0 & $\mathrm{BDL}$ \\
\hline $28 X-1,30-31$ & 256.60 & 91.535 & 10.975 & 9.96 & 0 & $\mathrm{BDL}$ \\
\hline $28 X-2,6-7$ & 257.86 & 88.745 & 10.64 & 9.88 & 0 & BDL \\
\hline
\end{tabular}

$\mathrm{IC}=$ inorganic carbon, $\mathrm{TC}=$ total carbon, $\mathrm{TN}=$ total nitrogen, $\mathrm{TOC}=$ total organic carbon. $\mathrm{BDL}=$ below detection limit $(\mathrm{TOC}<0.03 \mathrm{wt} \%)$. 
Table T21. Thermal conductivity results, Hole U1410A. (Continued on next page.)

\begin{tabular}{|c|c|c|c|c|c|}
\hline \multirow{2}{*}{$\begin{array}{l}\text { Core, section, } \\
\text { interval }(\mathrm{cm})\end{array}$} & \multirow[b]{2}{*}{$\begin{array}{l}\text { Depth } \\
\text { (mbsf) }\end{array}$} & \multicolumn{3}{|c|}{ Thermal conductivity $(\mathrm{W} /[\mathrm{m} \cdot \mathrm{K}])$} & \multirow{2}{*}{$\begin{array}{l}\text { Heating } \\
\text { power } \\
(\mathrm{W} / \mathrm{m})\end{array}$} \\
\hline & & Mean & $\begin{array}{l}\text { Standard } \\
\text { deviation }\end{array}$ & Observation & \\
\hline \multicolumn{6}{|l|}{ 342-U1410A- } \\
\hline $1 \mathrm{H}-3 \mathrm{~W}, 75$ & 3.01 & 0.993 & $2.41 \mathrm{E}-02$ & $0.959^{*}$ & 1.612 \\
\hline $1 \mathrm{H}-3 \mathrm{~W}, 75$ & 3.01 & & & $1.009^{*}$ & 1.612 \\
\hline $1 \mathrm{H}-3 \mathrm{~W}, 75$ & 3.01 & & & $1.011^{*}$ & 1.612 \\
\hline $2 \mathrm{H}-3 \mathrm{~W}, 75$ & 11.51 & 0.896 & $3.52 \mathrm{E}-02$ & $0.846^{*}$ & 1.612 \\
\hline $2 \mathrm{H}-3 \mathrm{~W}, 75$ & 11.51 & & & 0.921 & 1.612 \\
\hline $2 \mathrm{H}-3 \mathrm{~W}, 75$ & 11.51 & & & 0.920 & 1.612 \\
\hline $3 \mathrm{H}-3 \mathrm{~W}, 75$ & 21.01 & 0.971 & $5.50 \mathrm{E}-03$ & 0.970 & 1.612 \\
\hline $3 \mathrm{H}-3 \mathrm{~W}, 75$ & 21.01 & & & $0.965^{*}$ & 1.612 \\
\hline $3 \mathrm{H}-3 \mathrm{~W}, 75$ & 21.01 & & & 0.978 & 1.612 \\
\hline $4 \mathrm{H}-3 \mathrm{~W}, 75$ & 30.51 & 1.411 & $2.24 \mathrm{E}-02$ & 1.380 & 1.612 \\
\hline $4 \mathrm{H}-3 \mathrm{~W}, 75$ & 30.51 & & & 1.428 & 1.612 \\
\hline $4 \mathrm{H}-3 \mathrm{~W}, 75$ & 30.51 & & & 1.426 & 1.612 \\
\hline $5 \mathrm{H}-3 \mathrm{~W}, 75$ & 40.01 & 1.130 & $1.61 \mathrm{E}-02$ & 1.107 & 1.612 \\
\hline $5 \mathrm{H}-3 \mathrm{~W}, 75$ & 40.01 & & & $1.144^{*}$ & 1.612 \\
\hline $5 \mathrm{H}-3 \mathrm{~W}, 75$ & 40.01 & & & $1.138^{*}$ & 1.612 \\
\hline $6 \mathrm{H}-3 \mathrm{~W}, 75$ & 49.51 & 1.060 & 3.67E-02 & $1.008^{*}$ & 1.612 \\
\hline $6 \mathrm{H}-3 \mathrm{~W}, 75$ & 49.51 & & & 1.090 & 1.612 \\
\hline $6 \mathrm{H}-3 \mathrm{~W}, 75$ & 49.51 & & & 1.081 & 1.612 \\
\hline 7H-3W, 31 & 59.05 & 1.179 & $1.45 \mathrm{E}-02$ & 1.160 & 1.612 \\
\hline 7H-3W, 31 & 59.05 & & & $1.183^{*}$ & 1.612 \\
\hline 7H-3W, 31 & 59.05 & & & 1.195 & 1.612 \\
\hline $8 \mathrm{H}-3 \mathrm{~A}, 75$ & 68.51 & 1.156 & 1.67E-02 & 1.132 & 1.612 \\
\hline $8 \mathrm{H}-3 \mathrm{~A}, 75$ & 68.51 & & & $1.170^{*}$ & 1.612 \\
\hline $8 \mathrm{H}-3 \mathrm{~A}, 75$ & 68.51 & & & $1.165^{*}$ & 1.612 \\
\hline $9 \mathrm{H}-3 \mathrm{~A}, 30$ & 78.00 & 1.183 & $8.80 \mathrm{E}-03$ & 1.171 & 1.612 \\
\hline $9 \mathrm{H}-3 \mathrm{~A}, 30$ & 78.00 & & & $1.191^{*}$ & 1.612 \\
\hline $9 \mathrm{H}-3 \mathrm{~A}, 30$ & 78.00 & & & 1.187 & 1.612 \\
\hline $10 \mathrm{H}-3 \mathrm{~A}, 75$ & 85.69 & 1.199 & $2.01 \mathrm{E}-02$ & $1.173^{*}$ & 1.612 \\
\hline $10 \mathrm{H}-3 \mathrm{~A}, 75$ & 85.69 & & & $1.202^{*}$ & 1.612 \\
\hline $10 \mathrm{H}-3 \mathrm{~A}, 75$ & 85.69 & & & $1.222^{*}$ & 1.612 \\
\hline $11 \mathrm{H}-3 \mathrm{~A}, 75$ & 97.01 & 1.123 & $5.62 \mathrm{E}-02$ & 1.151 & 1.612 \\
\hline $11 \mathrm{H}-3 \mathrm{~A}, 75$ & 97.01 & & & 1.174 & 1.612 \\
\hline $11 \mathrm{H}-3 \mathrm{~A}, 75$ & 97.01 & & & 1.045 & 1.612 \\
\hline $12 \mathrm{H}-3 \mathrm{~A}, 75$ & 106.51 & 1.155 & $7.70 \mathrm{E}-03$ & 1.154 & 1.612 \\
\hline $12 \mathrm{H}-3 \mathrm{~A}, 75$ & 106.51 & & & $1.164^{*}$ & 1.612 \\
\hline $12 \mathrm{H}-3 \mathrm{~A}, 75$ & 106.51 & & & 1.145 & 1.612 \\
\hline $13 \mathrm{H}-3 \mathrm{~A}, 75$ & 114.98 & 1.150 & $3.70 \mathrm{E}-03$ & $1.145^{*}$ & 1.612 \\
\hline $13 \mathrm{H}-3 \mathrm{~A}, 75$ & 114.98 & & & $1.154^{*}$ & 1.612 \\
\hline $13 \mathrm{H}-3 \mathrm{~A}, 75$ & 114.98 & & & $1.150^{*}$ & 1.612 \\
\hline $14 \mathrm{H}-3 \mathrm{~A}, 75$ & 125.51 & 1.138 & 1.70E-02 & $1.114^{*}$ & 1.612 \\
\hline $14 \mathrm{H}-3 \mathrm{~A}, 75$ & 125.51 & & & $1.151^{*}$ & 1.612 \\
\hline $14 \mathrm{H}-3 \mathrm{~A}, 75$ & 125.51 & & & 1.149 & 1.612 \\
\hline $15 \mathrm{H}-3 \mathrm{~A}, 75$ & 134.99 & 1.144 & $1.59 \mathrm{E}-02$ & 1.151 & 1.612 \\
\hline $15 \mathrm{H}-3 \mathrm{~A}, 75$ & 134.99 & & & 1.159 & 1.612 \\
\hline $15 \mathrm{H}-3 \mathrm{~A}, 75$ & 134.99 & & & $1.122^{*}$ & 1.612 \\
\hline $16 \mathrm{H}-3 \mathrm{~W}, 75$ & 144.51 & 1.166 & $7.80 \mathrm{E}-03$ & 1.155 & 1.612 \\
\hline $16 \mathrm{H}-3 \mathrm{~W}, 75$ & 144.51 & & & $1.174^{*}$ & 1.612 \\
\hline $16 \mathrm{H}-3 \mathrm{~W}, 75$ & 144.51 & & & $1.168^{*}$ & 1.612 \\
\hline $17 X-3 W, 75$ & 154.01 & 1.135 & $2.20 \mathrm{E}-02$ & $1.109^{*}$ & 1.612 \\
\hline $17 X-3 W, 75$ & 154.01 & & & 1.163 & 1.612 \\
\hline $17 X-3 W, 75$ & 154.01 & & & $1.132^{*}$ & 1.612 \\
\hline $18 X-3 W, 75$ & 163.61 & 1.198 & $4.70 \mathrm{E}-03$ & 1.192 & 1.612 \\
\hline $18 \mathrm{X}-3 \mathrm{~W}, 75$ & 163.61 & & & $1.203^{*}$ & 1.612 \\
\hline $18 X-3 W, 75$ & 163.61 & & & $1.199^{*}$ & 1.612 \\
\hline $19 X-3 W, 75$ & 173.21 & 1.182 & $1.14 \mathrm{E}-02$ & 1.176 & 1.612 \\
\hline $19 X-3 W, 75$ & 173.21 & & & $1.172^{*}$ & 1.612 \\
\hline $19 X-3 W, 75$ & 173.21 & & & 1.198 & 1.612 \\
\hline $20 X-3 W, 75$ & 182.81 & 1.202 & $2.34 \mathrm{E}-02$ & $1.172^{*}$ & 1.612 \\
\hline $20 X-3 W, 75$ & 182.81 & & & $1.229^{*}$ & 1.612 \\
\hline $20 X-3 W, 75$ & 182.81 & & & $1.205^{*}$ & 1.612 \\
\hline $22 X-3 W, 75$ & 202.01 & 1.222 & $1.01 \mathrm{E}-02$ & 1.209 & 1.612 \\
\hline $22 \mathrm{X}-3 \mathrm{~W}, 75$ & 202.01 & & & 1.234 & 1.612 \\
\hline $22 X-3 W, 75$ & 202.01 & & & 1.224 & 1.612 \\
\hline $23 \mathrm{X}-3 \mathrm{~A}, 75$ & 211.51 & 1.431 & 2.37E-02 & 1.400 & 1.612 \\
\hline $23 \mathrm{X}-3 \mathrm{~A}, 75$ & 211.51 & & & $1.434^{*}$ & 1.612 \\
\hline $23 \mathrm{X}-3 \mathrm{~A}, 75$ & 211.51 & & & $1.458^{*}$ & 1.612 \\
\hline
\end{tabular}


Table T21 (continued).

\begin{tabular}{|c|c|c|c|c|c|}
\hline \multirow[b]{2}{*}{$\begin{array}{l}\text { Core, section, } \\
\text { interval }(\mathrm{cm})\end{array}$} & \multirow[b]{2}{*}{$\begin{array}{l}\text { Depth } \\
\text { (mbsf) }\end{array}$} & \multicolumn{3}{|c|}{ Thermal conductivity $(\mathrm{W} /[\mathrm{m} \cdot \mathrm{K}])$} & \multirow{2}{*}{$\begin{array}{r}\text { Heating } \\
\text { power } \\
(\mathrm{W} / \mathrm{m})\end{array}$} \\
\hline & & Mean & $\begin{array}{l}\text { Standard } \\
\text { deviation }\end{array}$ & Observation & \\
\hline $24 X-3 A, 75$ & 221.01 & 1.316 & $9.90 \mathrm{E}-03$ & $1.330^{*}$ & 1.612 \\
\hline $24 X-3 A, 75$ & 221.01 & & & $1.312^{*}$ & 1.612 \\
\hline $24 X-3 A, 75$ & 221.01 & & & $1.307^{*}$ & 1.612 \\
\hline $25 X-3 A, 75$ & 230.51 & 1.326 & $1.45 \mathrm{E}-02$ & $1.306^{*}$ & 1.612 \\
\hline $25 X-3 A, 75$ & 230.51 & & & $1.339 *$ & 1.612 \\
\hline $25 X-3 A, 75$ & 230.51 & & & $1.334^{*}$ & 1.612 \\
\hline $26 X-3 A, 75$ & 240.11 & 1.387 & $1.53 \mathrm{E}-02$ & $1.381^{*}$ & 1.612 \\
\hline $26 X-3 A, 75$ & 240.11 & & & $1.408^{*}$ & 1.612 \\
\hline $26 X-3 A, 75$ & 240.11 & & & $1.372^{*}$ & 1.612 \\
\hline $27 X-3 A, 75$ & 249.71 & 1.496 & $5.20 \mathrm{E}-03$ & $1.494^{*}$ & 1.612 \\
\hline $27 X-3 A, 75$ & 249.71 & & & 1.503 & 1.612 \\
\hline $27 X-3 A, 75$ & 249.71 & & & $1.491^{*}$ & 1.612 \\
\hline
\end{tabular}

* $=$ result obtained directly from the TK04 processing software. Other results were generated by the IODP uploader using raw data because they were rejected by the TK04 software. Thermal conductivity mean and standard deviation calculated from thermal conductivity observations. Heating power used to perform the measurement is also listed. 
Table T22. Core top and composite depth, Site U1410. (Continued on next page.)

\begin{tabular}{|c|c|c|c|c|c|}
\hline \multirow[b]{2}{*}{ Core } & \multicolumn{2}{|c|}{ Depth } & \multirow[b]{2}{*}{ Offset (m) } & \multirow{2}{*}{$\begin{array}{l}\text { Cumulative } \\
\text { offset (m) }\end{array}$} & \multirow[b]{2}{*}{ Comment } \\
\hline & (mbsf) & $(m$ CCSF) & & & \\
\hline \multicolumn{6}{|l|}{ 342-U1410A- } \\
\hline $1 \mathrm{H}$ & 0.00 & 0.00 & 0.00 & 0.00 & \\
\hline $2 \mathrm{H}$ & 8.50 & 7.70 & -0.80 & -0.80 & \\
\hline $3 \mathrm{H}$ & 18.00 & 18.70 & 1.50 & 0.70 & \\
\hline $4 \mathrm{H}$ & 27.50 & 28.95 & 0.75 & 1.45 & \\
\hline $5 \mathrm{H}$ & 37.00 & 38.20 & -0.25 & 1.20 & \\
\hline $6 \mathrm{H}$ & 46.50 & 48.00 & 0.30 & 1.50 & \\
\hline $7 \mathrm{H}$ & 56.00 & 58.35 & 0.85 & 2.35 & \\
\hline $8 \mathrm{H}$ & 65.50 & 67.85 & 0.00 & 2.35 & \\
\hline $9 \mathrm{H}$ & 75.00 & 79.45 & 2.10 & 4.45 & \\
\hline $10 \mathrm{H}$ & 84.50 & 90.04 & 1.09 & 5.54 & \\
\hline $11 \mathrm{H}$ & 94.00 & 98.54 & -1.00 & 4.54 & \\
\hline $12 \mathrm{H}$ & 103.50 & 108.54 & 0.50 & 5.04 & \\
\hline $13 \mathrm{H}$ & 113.00 & 117.99 & -0.05 & 4.99 & \\
\hline $14 \mathrm{H}$ & 122.50 & 128.39 & 0.90 & 5.89 & \\
\hline $15 \mathrm{H}$ & 132.00 & 137.39 & -0.50 & 5.39 & \\
\hline $16 \mathrm{H}$ & 141.50 & 146.89 & 0.00 & 5.39 & Slumped \\
\hline $17 X$ & 151.00 & 157.64 & 1.25 & 6.64 & \\
\hline $18 \mathrm{X}$ & 160.60 & 167.04 & -0.20 & 6.44 & \\
\hline $19 x$ & 170.20 & 176.64 & 0.00 & 6.44 & \\
\hline $20 x$ & 179.80 & 186.59 & 0.35 & 6.79 & \\
\hline $21 x$ & 189.40 & 196.19 & 0.00 & 6.79 & Disturbed \\
\hline $22 X$ & 199.00 & 205.79 & 0.00 & 6.79 & \\
\hline $23 x$ & 208.50 & 226.29 & 11.00 & 17.79 & \\
\hline $24 X$ & 218.00 & 236.64 & 0.85 & 18.64 & \\
\hline $25 X$ & 227.50 & 247.79 & 1.65 & 20.29 & \\
\hline $26 X$ & 237.10 & 257.39 & 0.00 & 20.29 & \\
\hline $27 X$ & 246.70 & 266.99 & 0.00 & 20.29 & \\
\hline $28 \mathrm{X}$ & 256.30 & 276.59 & 0.00 & 20.29 & \\
\hline \multicolumn{6}{|c|}{ 342-U1410B- } \\
\hline $1 \mathrm{H}$ & 0.00 & -0.10 & -0.10 & -0.10 & \\
\hline $2 \mathrm{H}$ & 3.80 & 4.75 & 1.05 & 0.95 & \\
\hline $3 \mathrm{H}$ & 13.30 & 13.85 & -0.40 & 0.55 & \\
\hline $4 \mathrm{H}$ & 22.80 & 23.95 & 0.60 & 1.15 & \\
\hline $5 \mathrm{H}$ & 31.30 & 32.90 & 0.45 & 1.60 & \\
\hline $6 \mathrm{H}$ & 39.70 & 41.50 & 0.20 & 1.80 & \\
\hline $7 \mathrm{H}$ & 49.20 & 50.60 & -0.40 & 1.40 & \\
\hline $8 \mathrm{H}$ & 58.70 & 62.00 & 1.90 & 3.30 & \\
\hline $9 \mathrm{H}$ & 66.80 & 71.05 & 0.95 & 4.25 & \\
\hline $10 \mathrm{H}$ & 76.30 & 80.73 & 0.18 & 4.43 & \\
\hline $11 \mathrm{H}$ & 85.80 & 90.72 & 0.49 & 4.92 & \\
\hline $12 \mathrm{H}$ & 90.80 & 95.72 & 0.00 & 4.92 & \\
\hline $13 \mathrm{H}$ & 100.30 & 105.92 & 0.70 & 5.62 & \\
\hline $14 \mathrm{H}$ & 109.80 & 115.22 & -0.20 & 5.42 & \\
\hline $15 \mathrm{H}$ & 119.30 & 125.27 & 0.55 & 5.97 & \\
\hline $16 \mathrm{H}$ & 128.80 & 135.07 & 0.30 & 6.27 & Tentative \\
\hline $17 \mathrm{H}$ & 138.30 & 144.42 & -0.15 & 6.12 & Tentative/Slumped? \\
\hline $18 \mathrm{H}$ & 147.80 & 153.67 & -0.25 & 5.87 & Slumped? \\
\hline $19 x$ & 153.80 & 160.67 & 1.00 & 6.87 & \\
\hline $20 x$ & 163.40 & 170.77 & 0.50 & 7.37 & Tentative \\
\hline $21 X$ & 173.00 & 180.57 & 0.20 & 7.57 & Tentative \\
\hline $22 X$ & 182.60 & 190.17 & 0.00 & 7.57 & Shattered liner \\
\hline $23 x$ & 187.60 & 194.97 & -0.20 & 7.37 & Tentative \\
\hline $24 X$ & 197.20 & 204.57 & 0.00 & 7.37 & Tentative \\
\hline $25 X$ & 206.80 & 213.67 & -0.50 & 6.87 & Tentative \\
\hline $26 X$ & 216.40 & 236.57 & 13.30 & 20.17 & \\
\hline $27 X$ & 226.00 & 246.17 & 0.00 & 20.17 & Tentative \\
\hline $28 X$ & 235.60 & 255.77 & 0.00 & 20.17 & \\
\hline \multicolumn{6}{|l|}{ 342-U1410C- } \\
\hline $1 \mathrm{H}$ & 0.00 & 0.15 & 0.15 & 0.15 & \\
\hline $2 \mathrm{H}$ & 6.80 & 6.95 & 0.00 & 0.15 & \\
\hline $3 \mathrm{H}$ & 16.30 & 17.65 & 1.20 & 1.35 & \\
\hline $4 \mathrm{H}$ & 25.80 & 27.37 & 0.22 & 1.57 & \\
\hline $5 \mathrm{H}$ & 35.30 & 36.87 & 0.00 & 1.57 & \\
\hline $6 \mathrm{H}$ & 44.80 & 46.77 & 0.40 & 1.97 & \\
\hline $7 \mathrm{H}$ & 54.30 & 57.29 & 1.02 & 2.99 & \\
\hline $8 \mathrm{H}$ & 63.80 & 66.82 & 0.03 & 3.02 & Tentative \\
\hline $9 \mathrm{H}$ & 73.30 & 76.47 & 0.15 & 3.17 & \\
\hline
\end{tabular}


Table T22 (continued).

\begin{tabular}{|c|c|c|c|c|c|}
\hline \multirow[b]{2}{*}{ Core } & \multicolumn{2}{|c|}{ Depth } & \multirow[b]{2}{*}{ Offset (m) } & \multirow{2}{*}{$\begin{array}{l}\text { Cumulative } \\
\text { offset }(\mathrm{m})\end{array}$} & \multirow[b]{2}{*}{ Comment } \\
\hline & (mbsf) & (m CCSF) & & & \\
\hline $10 \mathrm{H}$ & 82.80 & 87.41 & 1.44 & 4.61 & \\
\hline $11 \mathrm{H}$ & 89.80 & 94.21 & -0.20 & 4.41 & \\
\hline $12 \mathrm{H}$ & 99.30 & 105.11 & 1.40 & 5.81 & \\
\hline $13 \mathrm{H}$ & 108.80 & 114.96 & 0.35 & 6.16 & \\
\hline $14 \mathrm{H}$ & 118.30 & 125.86 & 1.40 & 7.56 & \\
\hline $15 \mathrm{H}$ & 127.80 & 136.76 & 1.40 & 8.96 & \\
\hline $16 \mathrm{H}$ & 137.30 & 147.36 & 1.10 & 10.06 & Slumped? \\
\hline $17 X$ & 146.80 & 156.86 & 0.00 & 10.06 & Slumped? \\
\hline $18 \mathrm{X}$ & 156.40 & 166.86 & 0.40 & 10.46 & \\
\hline $19 x$ & 166.00 & 176.56 & 0.10 & 10.56 & Tentative \\
\hline $20 x$ & 175.60 & 186.76 & 0.60 & 11.16 & \\
\hline $21 x$ & 185.20 & 196.36 & 0.00 & 11.16 & Tentative \\
\hline $22 x$ & 194.80 & 205.96 & 0.00 & 11.16 & \\
\hline $23 x$ & 204.40 & 216.56 & 1.00 & 12.16 & \\
\hline $24 X$ & 214.00 & 230.96 & 4.80 & 16.96 & \\
\hline $25 x$ & 223.60 & 240.51 & -0.05 & 16.91 & \\
\hline $26 x$ & 233.20 & 247.91 & -2.20 & 14.71 & \\
\hline $27 X$ & 242.80 & 257.51 & 0.00 & 14.71 & \\
\hline
\end{tabular}


Table T23. Splice tie points, Site U1410.

\begin{tabular}{|c|c|c|c|c|c|c|c|}
\hline \multirow{2}{*}{$\begin{array}{l}\text { Hole, core, section, } \\
\text { interval }(\mathrm{cm})\end{array}$} & \multicolumn{2}{|c|}{ Depth } & & \multirow{2}{*}{$\begin{array}{l}\text { Hole, core, section, } \\
\text { interval }(\mathrm{cm})\end{array}$} & \multicolumn{2}{|c|}{ Depth } & \multirow[b]{2}{*}{ Commen } \\
\hline & (mbsf) & (m CCSF) & & & (mbsf) & (m CCSF) & \\
\hline \multirow[t]{2}{*}{$342-$} & & & & $342-$ & & & \\
\hline & & & & U1410A-1H-1, 0 & 0.00 & 0.00 & \\
\hline U1410A-1H-5, 55 & 6.55 & 6.55 & Tie to & U1410B-2H-2, 30 & 5.60 & 6.55 & \\
\hline U1410B-2H-4, 26 & 8.56 & 9.52 & Tie to & $\mathrm{U} 1410 \mathrm{~A}-2 \mathrm{H}-2,32$ & 10.32 & 9.52 & \\
\hline U1410A-2H-6, 114 & 17.14 & 16.34 & Tie to & U1410B-3H-2, 138 & 15.79 & 16.34 & \\
\hline U1410B-3H-5, 60 & 19.51 & 20.05 & Tie to & U1410A-3H-1, 135 & 19.35 & 20.05 & \\
\hline U1410A-3H-6, 125 & 26.75 & 27.46 & Tie to & U1410B-4H-3, 51 & 26.31 & 27.46 & \\
\hline U1410B-4H-4, 115 & 28.45 & 29.60 & Tie to & U1410A-4H-1, 65 & 28.15 & 29.60 & \\
\hline U1410A-4H-4, 76 & 32.76 & 34.20 & Tie to & U1410B-5H-1, 130 & 32.60 & 34.20 & \\
\hline U1410B-5H-5, 130 & 38.60 & 40.19 & Tie to & U1410A-5H-2, 49 & 38.99 & 40.19 & \\
\hline U1410A-5H-4, 81 & 42.31 & 43.51 & Tie to & U1410B-6H-2, 51 & 41.71 & 43.51 & \\
\hline U1410B-6H-6, 96 & 48.20 & 50.01 & Tie to & U1410A-6H-2, 51 & 48.51 & 50.01 & \\
\hline U1410A-6H-6, 66 & 54.66 & 56.16 & Tie to & U1410B-7H-4, 106 & 54.76 & 56.16 & \\
\hline U1410B-7H-6, 80 & 57.50 & 58.90 & Tie to & U1410A-7H-1, 55 & 56.55 & 58.90 & \\
\hline U1410A-7H-7, 20 & 63.75 & 66.11 & Tie to & U1410B-8H-3, 111 & 62.81 & 66.11 & \\
\hline U1410B-8H-5, 37 & 65.07 & 68.37 & Tie to & U1410C-8H-2, 5 & 65.35 & 68.37 & Tentative \\
\hline U1410C-8H-6, 75 & 72.05 & 75.08 & Tie to & U1410B-9H-3, 103 & 70.83 & 75.08 & \\
\hline U1410B-9H-5, 111 & 73.91 & 78.17 & Tie to & U1410C-9H-2, 20 & 75.00 & 78.17 & \\
\hline U1410C-9H-5, 75 & 80.05 & 83.23 & Tie to & U1410B-10H-2, 100 & 78.80 & 83.23 & \\
\hline U1410B-10H-5, 118 & 83.48 & 87.91 & Tie to & U1410C-10H-1, 50 & 83.30 & 87.91 & \\
\hline U1410C-10H-4, 80 & 88.10 & 92.71 & Tie to & U1410B-11H-2, 49 & 87.79 & 92.71 & \\
\hline U1410B-11H-4, 5 & 90.35 & 95.26 & Tie to & U1410C-11H-1, 105 & 90.85 & 95.26 & \\
\hline U1410C-11H-5, 115 & 96.91 & 101.33 & Tie to & U1410A-11H-2, 129 & 96.79 & 101.33 & \\
\hline U1410A-11H-6, 85 & 102.35 & 106.87 & Tie to & U1410B-13H-1, 95 & 101.25 & 106.87 & \\
\hline U1410B-13H-4, 90 & 105.70 & 111.33 & Tie to & U1410A-12H-2, 129 & 106.29 & 111.33 & \\
\hline U1410A-12H-5, 119 & 110.69 & 115.72 & Tie to & U1410B-14H-1, 50 & 110.30 & 115.72 & \\
\hline U1410B-14H-6, 5 & 117.35 & 122.78 & Tie to & U1410A-13H-4, 132 & 117.79 & 122.78 & \\
\hline U1410A-13H-7, 31 & 121.28 & 126.27 & Tie to & U1410B-15H-1, 100 & 120.30 & 126.27 & \\
\hline U1410B-15H-4, 60 & 124.40 & 130.38 & Tie to & U1410A-14H-2, 49 & 124.49 & 130.38 & \\
\hline U1410A-14H-6, 19 & 130.19 & 136.07 & Tie to & U1410B-16H-1, 100 & 129.80 & 136.07 & Tentative \\
\hline U1410B-16H-4, 100 & 134.30 & 140.58 & Tie to & U1410A-15H-3, 21 & 135.19 & 140.58 & \\
\hline U1410A-15H-6, 55 & 140.03 & 145.42 & Tie to & U1410B-17H-1, 100 & 139.30 & 145.42 & Small overlap \\
\hline U1410B-17H-5, 140 & 144.79 & 150.90 & Tie to & U1410A-16H-3, 101 & 145.51 & 150.90 & \\
\hline U1410A-16H-5, 128 & 148.78 & 154.17 & Tie to & U1410B-18H-1, 50 & 148.30 & 154.17 & \\
\hline U1410B-18H-4, 45 & 152.75 & 158.64 & Tie to & U1410A-17X-1, 100 & 152.00 & 158.64 & \\
\hline U1410A-17X-4, 94 & 156.44 & 163.07 & Tie to & U1410B-19X-2, 90 & 156.20 & 163.07 & \\
\hline U1410B-19X-7, 50 & 162.71 & 169.56 & Tie to & U1410C-18X-2, 120 & 159.10 & 169.56 & \\
\hline U1410C-18X-5, 140 & 163.80 & 174.24 & Tie to & U1410B-20X-3, 45 & 166.87 & 174.24 & Tentative \\
\hline U1410B-20X-6, 25 & 171.17 & 178.56 & Tie to & U1410C-19X-2, 50 & 168.00 & 178.56 & Tentative \\
\hline U1410C-19X-4, 50 & 171.00 & 181.57 & Tie to & U1410B-21X-1, 100 & 174.00 & 181.57 & Tentative \\
\hline U1410B-21X-6, 10 & 180.60 & 188.16 & Tie to & U1410C-20X-1, 140 & 177.00 & 188.16 & \\
\hline U1410C-20X-7, 10 & 184.61 & 195.77 & Tie to & U1410B-23X-1, 80 & 188.40 & 195.77 & Small overlap \\
\hline U1410B-23X-5, 40 & 194.00 & 201.36 & Tie to & U1410C-21X-4, 50 & 190.20 & 201.36 & Tentative \\
\hline U1410C-21X-6, 120 & 193.90 & 205.07 & Tie to & U1410B-24X-1, 50 & 197.70 & 205.07 & Small overlap \\
\hline U1410B-24X-3, 20 & 200.40 & 207.78 & Tie to & U1410A-22X-2, 49 & 200.99 & 207.78 & \\
\hline U1410A-22X-6, 118 & 207.68 & 214.47 & Tie to & U1410B-25X-1, 80 & 207.60 & 214.47 & Small overlap \\
\hline U1410B-25X-4, 40 & 211.70 & 218.56 & Tie to & U1410C-23X-2, 50 & 206.40 & 218.56 & \\
\hline U1410C-23X-CC, 27 & 214.07 & 226.23 & Append to & U1410A-23X-1, 5 & 208.55 & 226.34 & \\
\hline U1410A-23X-6, 13 & 216.13 & 233.91 & Tie to & U1410C-24X-2, 145 & 216.95 & 233.91 & \\
\hline U1410C-24X-6, 10 & 221.60 & 238.57 & Tie to & U1410B-26X-2, 50 & 218.40 & 238.57 & \\
\hline U1410B-26X-5, 100 & 223.40 & 243.56 & Tie to & U1410C-25X-3, 5 & 226.65 & 243.56 & \\
\hline U1410C-25X-5, 45 & 230.05 & 246.97 & Tie to & U1410B-27X-1, 80 & 226.80 & 246.97 & Small overlap \\
\hline U1410B-27X-7, 60 & 235.31 & 255.48 & Append to & U1410B-28X-1, 5 & 235.65 & 255.82 & \\
\hline U1410B-28X-3, 115 & 239.75 & 259.92 & Tie to & U1410A-26X-2, 103 & 239.63 & 259.92 & Tentative \\
\hline U1410A-26X-4, 139 & 242.99 & 263.28 & Append to & U1410A-27X-1, 13 & 246.83 & 267.12 & \\
\hline U1410A-27X-6, 60 & 254.80 & 275.09 & Append to & U1410A-28X-1, 13 & 256.43 & 276.72 & \\
\hline U1410A-28X-CC, 32 & 258.65 & 278.94 & & & & & \\
\hline
\end{tabular}

